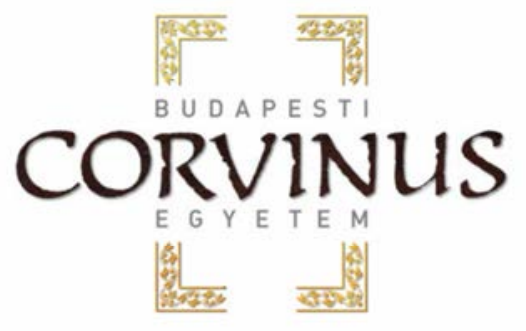

\title{
IN VITRO REGENERÁCIÓ ÉS SZAPORODÁS KÜLÖNLEGES ÚTJA SPATHIPHYLLUM HIBRIDEK ESETÉN
}

\author{
Doktori értekezés
}

\author{
Szerző: \\ MOSONYI ISTVÁN DÁNIEL
}

Témavezetö:

Tillyné dr. Mándy Andrea

Budapest, 2014 


\begin{abstract}
A doktori iskola
megnevezése: Kertészettudományi Doktori Iskola

tudományága: Növénytermesztési és kertészeti tudományok

vezetője: $\quad$ Dr. Tóth Magdolna

egyetemi tanár, DSc

Budapesti Corvinus Egyetem, Kertészettudományi Kar, Gyümölcstermő Növények Tanszék

Témavezető: $\quad$ Tillyné dr. Mándy Andrea

Budapesti Corvinus Egyetem, Kertészettudományi Kar, Dísznövénytermesztési és Dendrológiai Tanszék
\end{abstract}

\begin{abstract}
A jelölt a Budapesti Corvinus Egyetem Doktori Szabályzatában elöírt valamennyi feltételnek eleget tett, az értekezés mühelyvitájában elhangzott észrevételeket és javaslatokat az értekezés átdolgozásakor figyelembe vette, azért az értekezés védési eljárásra bocsátható.
\end{abstract}


A Budapesti Corvinus Egyetem Élettudományi Területi Doktori Tanácsának 2014. június 3-ai határozatában a nyilvános vita lefolytatására az alábbi bíráló Bizottságot jelölte ki:

\title{
BÍRÁLÓ BIZOTTSÁG:
}

\author{
Elnöke
}

Rimóczi Imre, DSc, Budapesti Corvinus Egyetem

Tagjai

Fári Miklós, DSc, Debreceni Egyetem

Horváthné Baracsi Éva, PhD, Pannon Egyetem

Opponensek

Dobránszki Judit, CSc, Debreceni Egyetem

Mészáros Annamária, $\mathrm{PhD}$ (nyug.)

Titkár

Kohut Ildikó, PhD, Budapesti Corvinus Egyetem 


\section{TARTALOMJEGYZÉK}

2 RÖVIDÍTÉSEK JEGYZÉKE

\section{IRODALMI ÁTTEKINTÉS}

$3.1 \quad$ A Spathiphyllum Schott nemzetség..........................................................................................................8

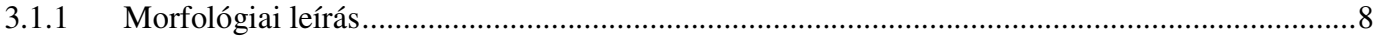

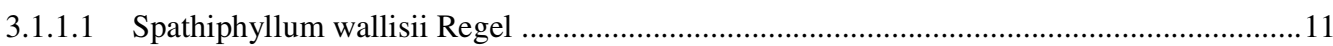

3.1.1.2 Spathiphyllum floribundum (Linden \& André) N. E. Br. .............................................11

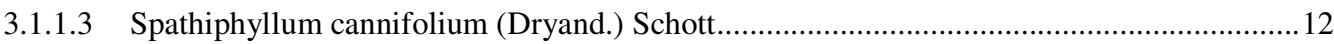

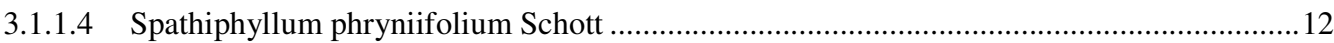

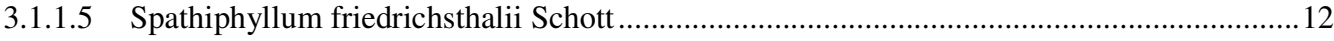

3.1.2 A termesztett alapfajok és kertészeti hibridek környezeti igényei ......................................... 13

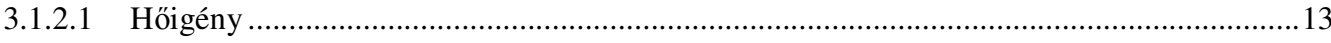

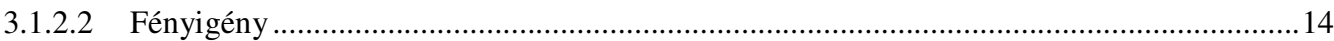

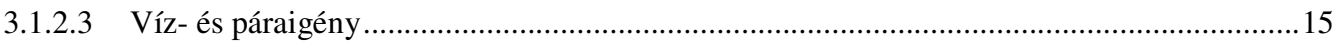

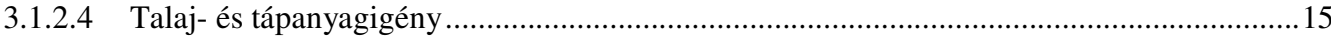

3.1.3 Jelentőség, felhasználás................................................................................................ 15

3.1.4 A Spathiphyllum hibridek piaci helyzete ..................................................................... 16

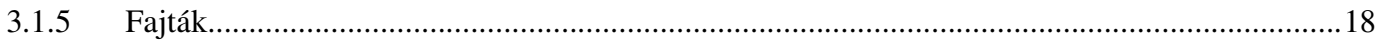

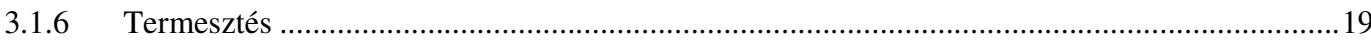

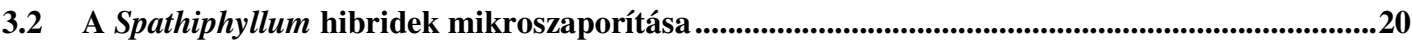

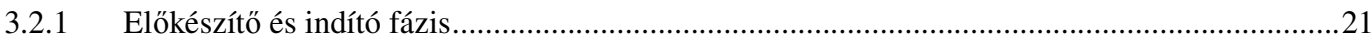

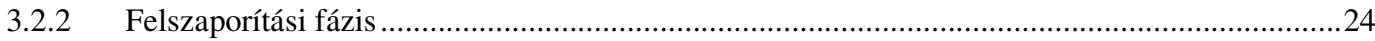

3.2.2.1 Hajtáscsúcskultúra és organogenezis.............................................................................24

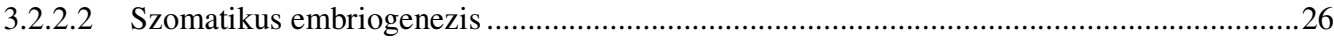

3.2.3 Gyökereztetés és akklimatizálás................................................................................28

3.3 A Spathiphyllum hibridek nemesítéséhez felhasznált egyéb in vitro technikák ...............................33

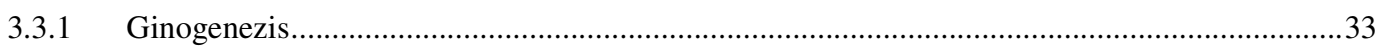

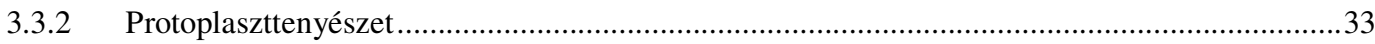

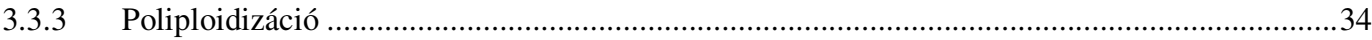

3.4 Speciális szerveződési formák in vitro környezetben ...........................................................35

3.4.1 A páfrányok esetén előforduló 'green globular body' (GGB) …...........................................35

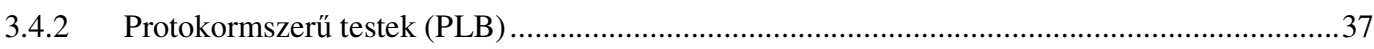

3.4.3 A Spathiphyllum esetében előforduló képződmények (GGb) ...............................................40 
3.5 In vitro környezet föbb hatásai a növények élettani jellemzőire

41

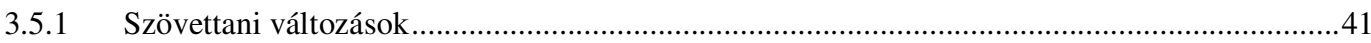

3.5.2 Változások a fotoszintetikus rendszerben ...........................................................................42

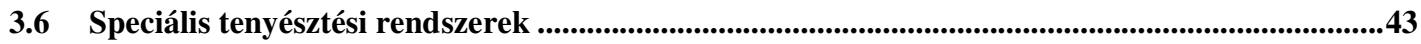

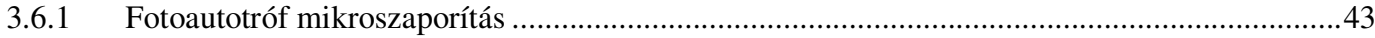

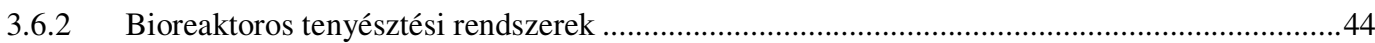

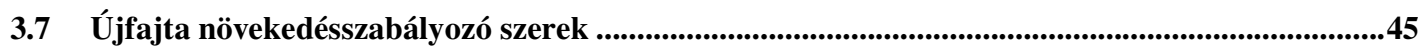

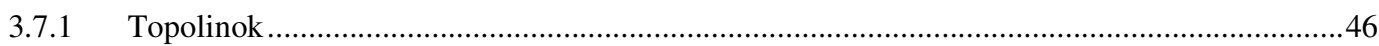

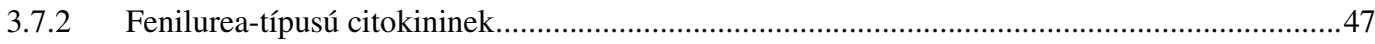

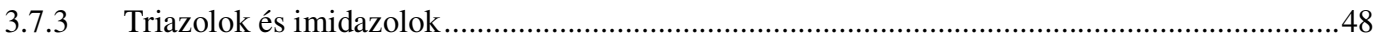

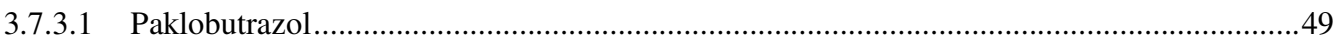

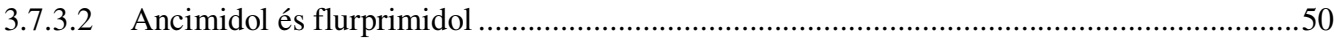

$4 \quad$ ANYAG ÉS MÓDSZER.......................................................................................52

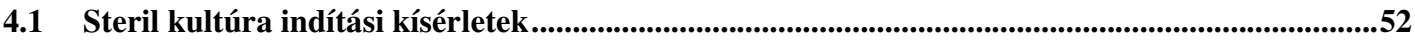

4.1.1 Indítás intenzív virágzásban lévő spadixból..................................................................52

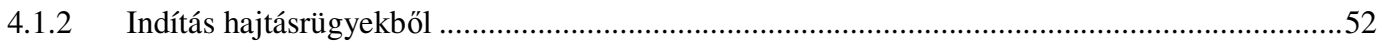

4.1.3 A virágzat érettségének hatása a tenyészet indítási fázisában ..............................................53

4.1.4 Indítás akklimatizált növények virágzatából .......................................................................54

4.2 A Spathiphyllum GGb telepekkel folytatott kísérletek .................................................................55

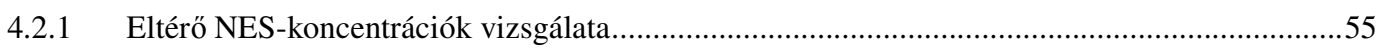

4.2.2 Különböző citokininek alkalmazása folyékony tápközegben ..............................................55

4.2.3 Emelt makroelem- és szacharóz koncentráció hatásának vizsgálata .......................................56

4.2.4 Triazol típusú növekedési retardánsok hatásának vizsgálata ................................................57

4.3 A Spathiphyllum sarjtenyészeteivel folytatott kísérletek ...........................................................57

4.3.1 Különböző szénhidráttípusok hatásának vizsgálata .............................................................58

4.3.2 Emelt makroelem- és szénhidrát-koncentrációk hatásának vizsgálata ....................................58

4.3.3 A paklobutrazol hatásának vizsgálata ..................................................................................59

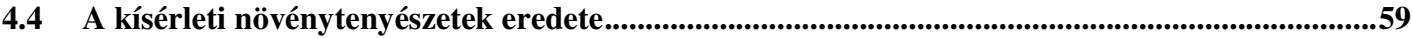

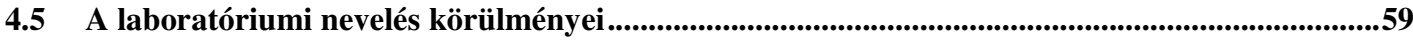

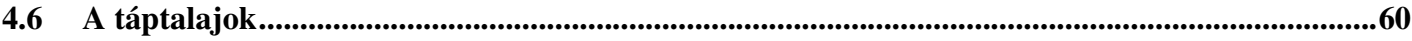

4.7 Morfológiai paraméterek mérése .......................................................................................................60

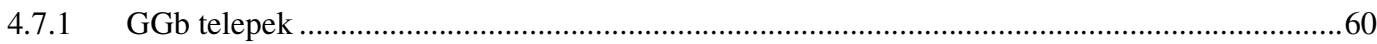

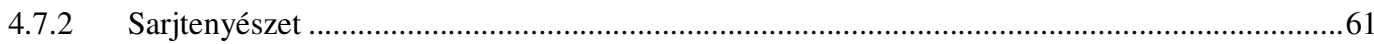

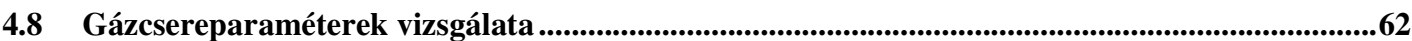




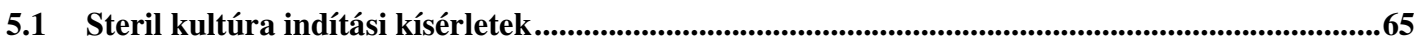

5.2 A Spathiphyllum GGb-telepekkel folytatott kísérletek ....................................................................71

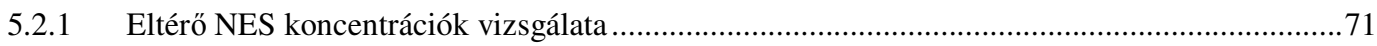

5.2.2 Különböző citokininek hatásának vizsgálata folyékony tápközegben ......................................73

5.2.3 Emelt makroelem- és szacharóz-koncentráció hatásának vizsgálata......................................79

5.2.4 Triazol típusú növekedési retardánsok hatásának vizsgálata ...................................................84

5.2.4.1 Paklobutrazol hatása a GGb-tenyészetekre ............................................................... 84

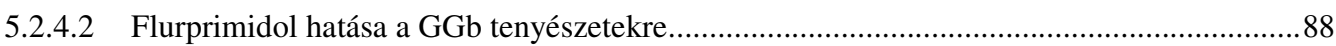

5.3 A Spathiphyllum sarjtenyészeteivel folytatott kísérletek .......................................................92

5.3.1 Különböző szénhidráttípusok hatásának vizsgálata .............................................................92

5.3.2 Emelt makroelem- és szénhidrát-koncentráció hatásának vizsgálata......................................95

5.3.3 A paklobutrazol hatásának vizsgálata .......................................................................... 102

5.3.3.1 A növények morfológiai paramétereire gyakorolt hatás.................................................. 102

5.3.3.2 Fotoszintetikus ráta, sztómakonduktancia, transzspiráció ..............................................104

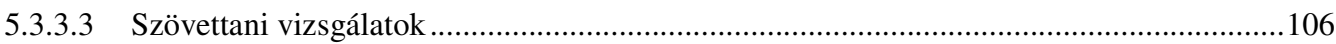

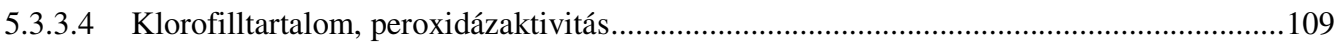

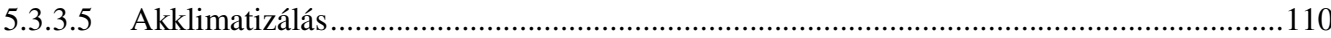

6 KÖVETKEZTETÉSEK ..............................................................................111

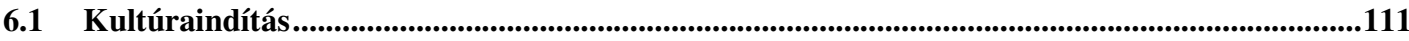

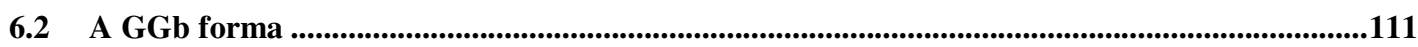

6.2.1 A GGb-telepek szaporodási rátája................................................................................111

6.2.2 A GGb forma sarjjá alakulása .................................................................................... 112

6.2.3 A GGb forma mibenléte .......................................................................................... 113

6.3 A szénhidráttípusok hatása a sarjtenyészetre ................................................................................114

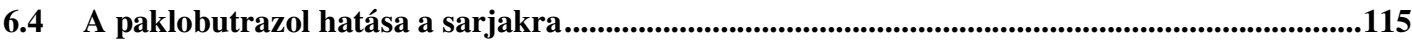

6.5 A gyakorlat számára hasznosítható eredmények.........................................................................117

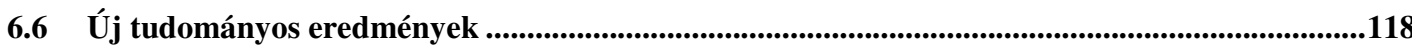




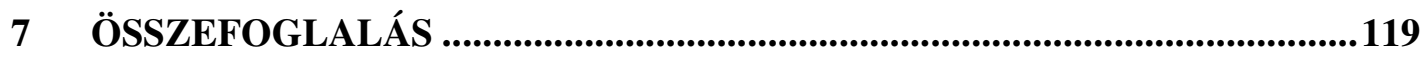

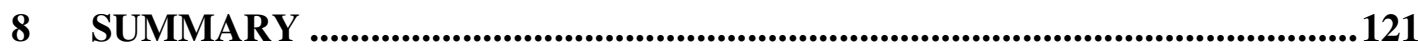

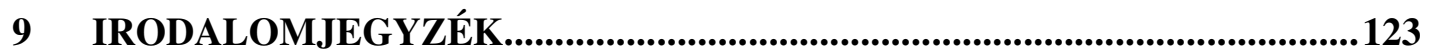

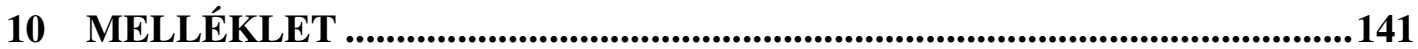

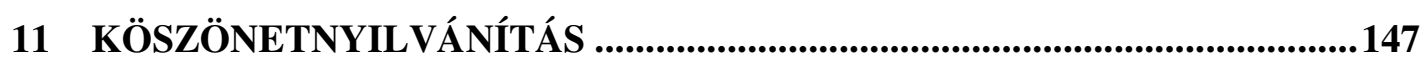




\section{Bevezetés és célkitűzés}

„A tudomány tévedései és hibái nem nevetségesek, hiszen a tudatosan vállalt kockázatban keletkeznek. Ennek megértése jogosít fel hipotézisek kimondására, mert még akkor is, ha ezek hamar összeomlanak, kudarcuk a helyes úton talál bennünket. Igen az ember, történetének hajnalától kezdve, mindig ezt az utat kereste, még akkor is, ha nem tudott róla."

(Stanisław Lem: Summa Technologiae)

A dísznövények szerepe egyre inkább felértékelődik a modern társadalmak városiasodott környezetében. Szerepük a dekoráción túl az emberek azon növekvő igényének kielégítése is, hogy természetközeli környezetet hozzanak létre maguk körül. Növényalkalmazási szempontból az épített környezet, mint ökológiai tér egy olyan speciális élőhely, mely elsősorban az emberek elvárásaihoz igazodik, ami nagyban eltér a legtöbb növény környezeti igényeitől. Ebböl kifolyólag csak olyan növényeket lehet ezekben a terekben alkalmazni, melyek tág türőképességgel rendelkeznek. A dísznövénynemesítés és -termesztés célja, hogy ilyen növényeket létrehozzanak, szelektáljanak és nagy mennyiségben elérhetővé tegyenek.

A Spathiphyllum fajták, azaz a vitorlavirágok megfelelnek a fenti célnak, kiválóan alkalmasak beltéri alkalmazásra, melyet jól bizonyít, hogy naponta találkozhatunk velük tömegesen közintézményekben. A vitorlavirágok nagy mennyiségben termesztett és nagy kereskedelmi forgalommal rendelkező, világszerte elterjedt, népszerü cserepes virágos dísznövények. Termesztésük és beltéri tartásuk könnyü, jó türőképességüknek köszönhetően. A cserepes virágos dísznövények piacán az elmúlt évtizedben mindig benne voltak az első 10 legnagyobb forgalommal rendelkező növény listájában. A szaporítóanyag-előállításának technológiája ezért folyamatosan fejlődik, újabb és újabb módszerekkel. Ezen technológiák fejlesztése során mindig fő szerepet kap a költséghatékonyság, melyet legfőképpen a technológiai lépések automatizálásával lehet elérni. A vitorlavirágok in vitro vegetatív szaporítóanyag-előállítása ma is jelentős mértékü, amellett, hogy már léteznek magról vethető homozigóta fajtasorozatok is. Ezek megjelenése a 90-es évek elején visszavetette ugyan a vegetatív in vitro szaporítóanyagelőállítást, mára a kétféle szaporítási eljárás azonban jól megfér egymás mellett, lévén, hogy generatív úton nem mindegyik, a kereskedelem által igényelt típust lehet szaporítani. Dolgozatom fö témája a Spathiphyllum taxonok in vitro szaporítóanyagelőállításának egy új, korábban még nem alkalmazott módszere, mellyel a hagyományos, a genetikai stabilitás megőrzését szem előtt tartó organogenezis útján végzett, de nagyléptékü 
(scale-up) bioreaktoros technológiára is potenciálisan alkalmas regenerációs lehetőséget kívánok bemutatni. A módszer alapja a vitorlavirágoknál spontán megfigyelt és indukálható speciális rügyszerü szervi-szöveti képződmény, mely a virágtorzsákon keletkezik. A kísérleteim célja, hogy vizsgáljam:

- ennek a képződménynek a kialakulását virágtorzsából és hajtásokból,

- in vitro körülmények között történő szaporításra való alkalmasságát,

- belőle hajtások, sarjak regenerációjának folyamatát, feltételeit

- a hajtástenyészet alternatív módjaként történő alkalmazásának lehetőségét.

Elsősorban gyakorlati szemszögből igyekszem vizsgálni a jelenséget, remélve, hogy a kapott eredmények így könnyebben és közvetlenebbül átültethetők és alkalmazhatók a gyakorlatban. Mivel az irodalomban nem találhatók adatok és leírások ilyen vagy ehhez hasonló jelenségről, ezért a téma újdonsága miatt, és a rendelkezésemre álló lehetőségeket figyelembe véve, módszerként az empirikus megközelítést alkalmazom a téma kidolgozásához. 


\section{Rövidítések jegyzéke}

\begin{tabular}{|c|c|}
\hline $1 / 2 \times$ & 0,5 -szeres \\
\hline $1 / 2 \times \mathrm{MS}$ & fél makroelem koncentrációjú MS táptalaj \\
\hline $1 \times$ & 1-szeres \\
\hline $2,4-\mathrm{D}$ & diklórfenoxiecetsav \\
\hline $2 x$ & 2-szeres \\
\hline 2-iP & 2-izopenteniladenin \\
\hline $\mathrm{AC}$ & aktív szén \\
\hline BA & benziladenin \\
\hline $\mathrm{BR}$ & benziladenin-ribozid \\
\hline DV & desztillált víz \\
\hline $\mathrm{EtOH}$ & etanol \\
\hline FP & flurprimidol \\
\hline $\mathrm{GA}_{3}$ & gibberellinsav \\
\hline GGB & green globular body \\
\hline GGb & green globular bud \\
\hline IES & indolecetsav \\
\hline IMA & imazalil \\
\hline IVS & indolvajsav \\
\hline KIN & kinetin \\
\hline LS & Linsmayer-Skoog táptalaj \\
\hline MS & Murashige-Skoog táptalaj \\
\hline MT & meta-topolin \\
\hline MTR & meta-topolin-ribozid \\
\hline NES & naftilecetsav \\
\hline OT & orto-topolin \\
\hline PBA & tetrahidropiranil-benziladenin \\
\hline PBZ & paklobutrazol \\
\hline PLB & protocorm like body \\
\hline POD & peroxidáz \\
\hline SZACH. & szacharóz \\
\hline TDZ & thidiazuron \\
\hline $\mathrm{Z}$ & zeatin \\
\hline
\end{tabular}




\section{Irodalmi áttekintés}

\subsection{A Spathiphyllum Schott nemzetség}

A nemzetségbe BUNTING (1960) monográfiája szerint 36 örökzöld, rizómás, évelő faj tartozik (2. ábra), CARDONA (2004) összefoglaló munkája szerint az újonnan leírt fajokkal együtt ez a szám már 50-re emelkedett. Ezek a fajok túlnyomórészt Dél-Amerika trópusi területein élnek, egy faj Indonéziában honos (DANERT et al., 1981), illetve a Fülöp-szigeteken is előfordul néhány faj (CARDONA, 2004). Sok Kolumbiában élő Spathiphyllum fajt európai botanikusok írtak le a 19. században, miközben potenciálisan dísznövényként alkalmazható fajokat kerestek (CARDONA, 2004). A nemzetséget Schott írta le 1832-ben (BUNTING, 1960). Rendszertani besorolás:

$$
\begin{aligned}
& \text { MAGNOLIOPHYTA - Zárvatermők törzse } \\
& \text { LILIOPSIDA - Egysziküek osztálya } \\
& \text { ALISMATALES - Hidőrvirágúak rendje } \\
& \text { ARACEAE - Kontyvirágfélék családja } \\
& \text { (UDVARDY, 2008) }
\end{aligned}
$$

\subsubsection{Morfológiai leírás}

A fajok alig különböznek egymástól (ROHWER, 2002), taxonómiai meghatározásuk nehéz. Más, Araceae családba tartozó nemzetségektől könnyen elkülöníthetőek az alábbi bélyegek alapján: kétivarú virágok takarótájjal, maradó levélszerü spatha, a levélnyelek kétharmad vagy nagyobb része levélhüvely, a pollen barázdált felszínü, de nem apertúrált, terreszter habitus (CARDONA, 2004). A szár rövid, felálló vagy kúszó (sokszor szárnélkülinek tünő). Leveleik laza rozettában állnak, egyszerüek, hosszú levélnyéllel rendelkeznek, a levéllemez erősen erezett, vége csúcsba keskenyedő, a levélgerinc kiemelkedő. Felegyenesedett, fehér torzsavirágzattal (spadix) rendelkeznek, ebben helyezkednek el kétivarú, többnyire illatos, apró virágaik, melyek az alaptól a csúcs felé haladva nyílnak. A kontyvirágfélékre jellemző torzsavirágzatot nagyméretü, világos színű (fehér vagy krémszínű) virágzati buroklevél (spatha) veszi körül, de nem borítja be kifejlődés után (ACEVEDO-RODRÍGUEZ et STRONG, 2005). A virágzás tartós, a spatha fokozatosan (néhány hét után) zöldül el (HEITZ, 2002). Termésük bogyó, zöld színü, 1-8 mag található bennük, a magok hosszúkásak, ellipszoidok vagy tojás alakúak (ACEVEDO-RODRÍGUEZ et STRONG, 2005). A nemzetségen belüli szekciók (Spathiphyllum, Dysspathiphyllum, Massowia, Amomophyllum) elkülönítése a lepellevelek forrtsága, a bibe alakja és lepelhez képesti hossza, és a spatha-nak a kocsányhoz való csatlakozása alapján történik (1. ábra). A fajok elkülönítéséhez a levéllemez hosszúság/szélesség 
aránya, a levéllemezen belül az elsődleges erek száma és kiindulási pontjuknál az egymással bezárt szögük, a spatha alakja és hossz/szélesség aránya a leginkább meghatározó bélyeg (BUNTING, 1960).
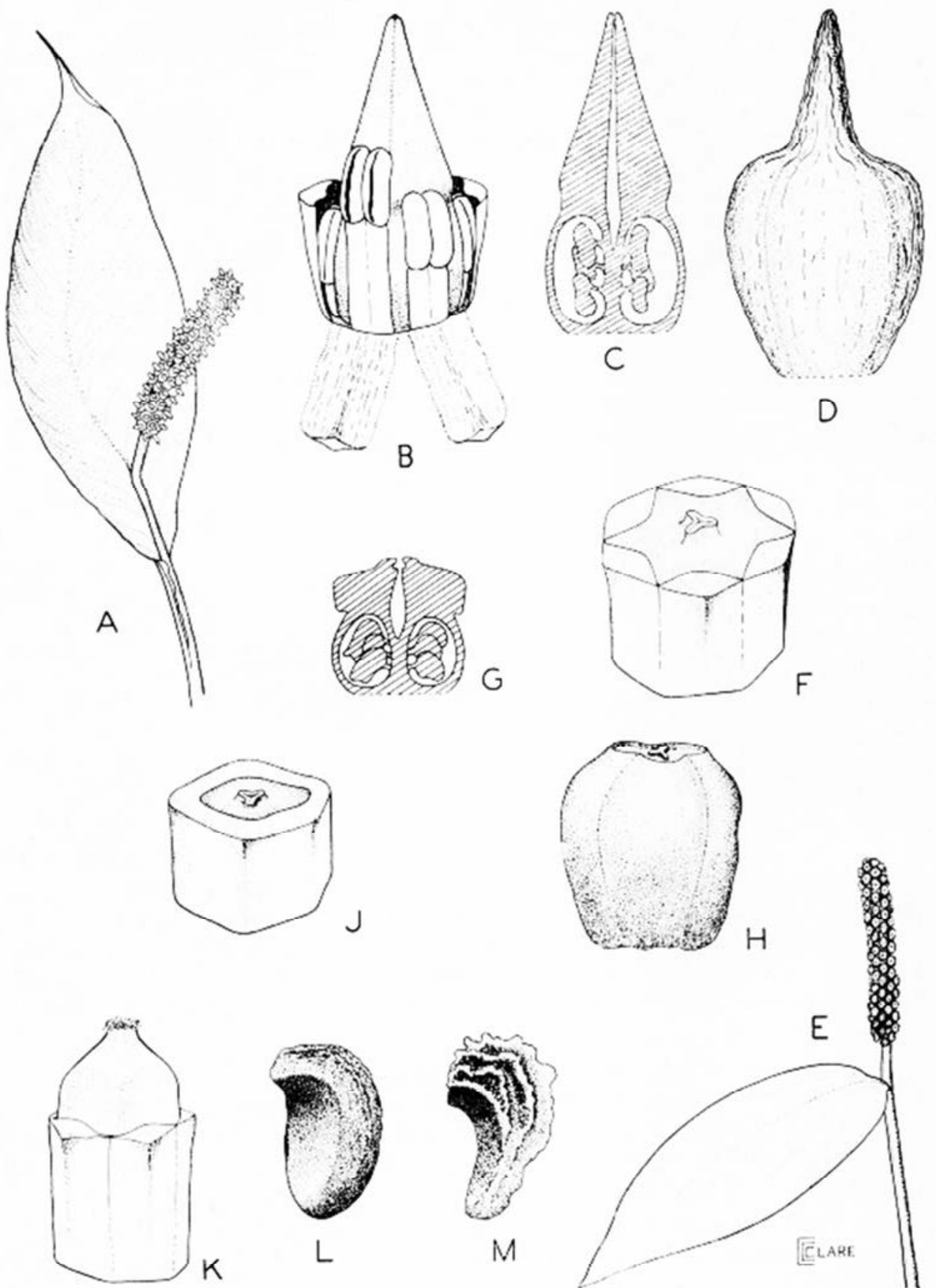

1. ábra. (A)-(D). reproduktív szervek a Spathyphyllum sect. Spathiphyllum fajainál: (A) virágzat. (B) virág (10x) (C) bibe hosszirányú metszete. (D) termés (6×). (E) Massowia, Amomophyllum és Dysspathiphyllum szekciók fajainak virágzata. (F)-(H) reproduktív szervek az Amomophyllum szekció fajainál. (F) virág (10×). (G) bibe hosszirányú metszete. (H) termés (6×) (a Massowia szekcióra is jellemzö). (J) Massowia szekcióra jellemző virág (10×). (K) a $S$. humboldtii (sect. Dysspathiphyllum) virága (10×). (L) sima felületű mag (12×). (M) barázdás felületủ mag (12×), BUNTING, 1960 nyomán. 


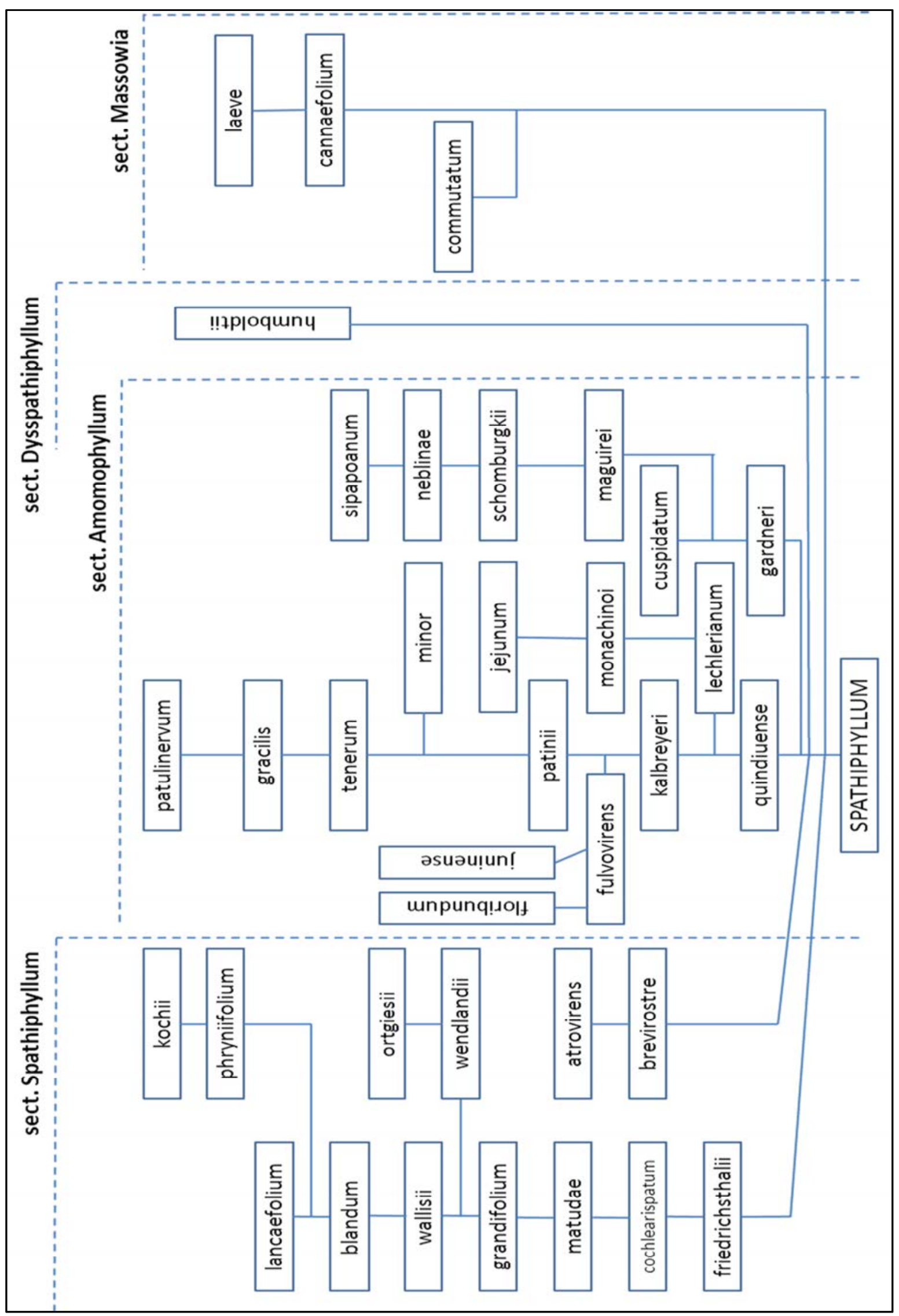

2. ábra. A Spathiphyllum nemzetség szekciói és fajai Bunting (1960) nyomán. 
Föbb fajok, melyek kertészeti jelentőséggel rendelkeznek, vagy rendelkeztek, a ma kereskedelmi forgalomban lévő hibridek szülöfajaiként: $S$. wallisii, S. floribundum, S. cannifolium (korábbi írásmód: S. cannaefolium), S. phryniifolium, S. friedrichsthalii.

\subsubsection{Spathiphyllum wallisii Regel}

1876-ban fedezte fel GuSTAV WALLIS, német botanikus Kolumbiában, és küldött belöle példányokat a szentpétervári botanikus kertnek (RÖBER et al., 1994). Nem szőrözött, felálló, 50 cm magasra is megnövő faj, nagyon rövid rizómával. A levelek lazán állnak, a levéllemezek felfelé törnek, 12-22 cm hosszúak, 2-4 cm szélesek, elliptikusak, papírszerüek, a főér vaskos, kifejezetten a fonáki oldalon, a másodlagos erek kevésbé kifejezettek. A levéllemez csúcsa kihegyesedő, alapja nyélbe keskenyedő, kissé aszimmetrikus, a levéllemez széle kissé hullámos. A levélnyél felegyenesedő, majdnem teljesen hengeres, 13-25 cm hosszú. A virágzat felálló, a virágzati kocsány $45 \mathrm{~cm}$ hosszú is lehet, a spatha szintén felálló, zöld, levélszerü, hosszúkáslándzsás, kb. $11 \mathrm{~cm}$ hosszú, a csúcsán hegyes. A spadix kb. $3 \mathrm{~cm}$ hosszú. A bogyók zöldek, kúposak, 4 mm hosszúak, a torzsa teljes hosszában helyezkednek el (3. ábra).

Előfordulása: Venezuela, Kolumbia (ACEVEDO-RODRÍGUEZ et STRONG, 2005), Costa Rica, Panama (BOWN, 2010).

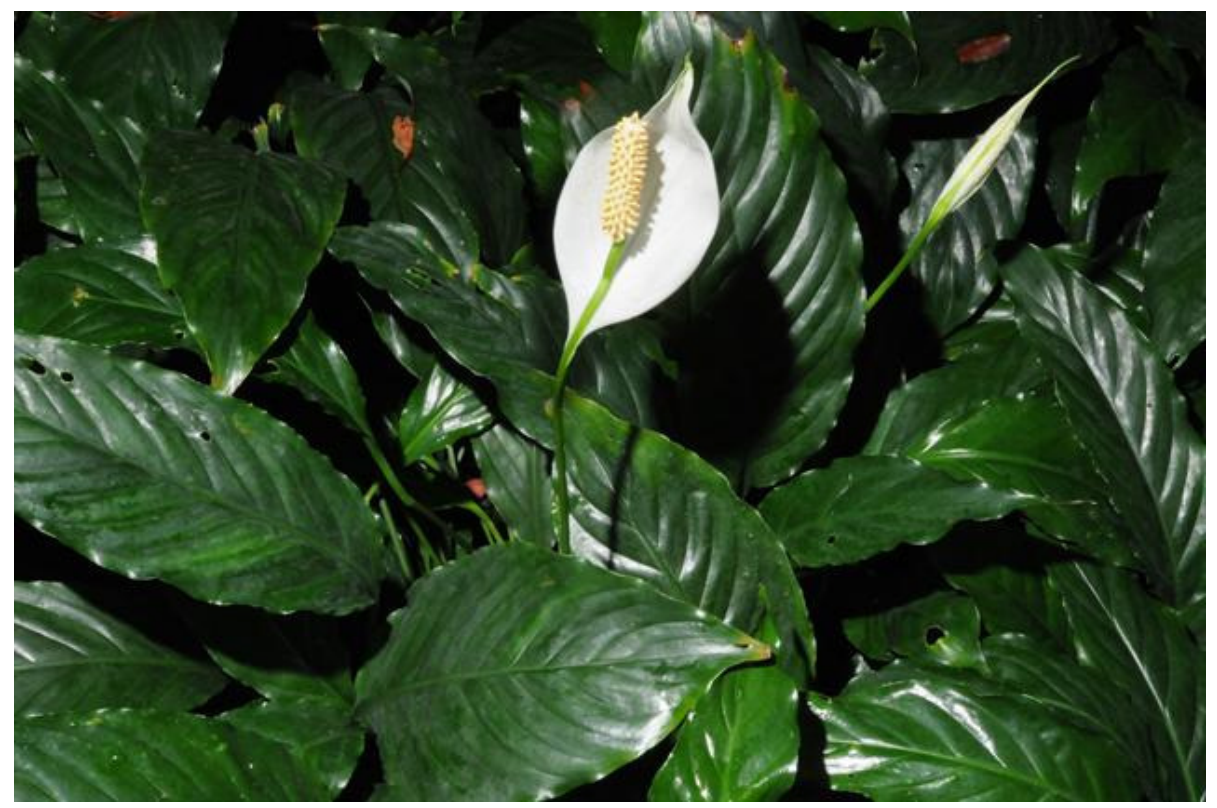

3. ábra. Spathiphyllum wallisii (Forrás: Biopix, JC Schou. Licensz: CC BY-NC 3.0).

\subsubsection{Spathiphyllum floribundum (Linden \& André) N. E. Br.}

Ezt a fajt elöször Anthurium floribundum néven írta le LINDEN és ANDRÉ 1874-ben (CARDONA, 2004). A növény 30 cm-nél nem magasabb, sötétzöld leveleinek bársonyos fénye van, a levéllemez a főér mentén némileg világosabb, 2-3-szor hosszabb, mint amilyen széles (4. ábra). A hófehér spatha 6-8 cm hosszú és 2-5 cm széles, 20-30 cm hosszú nyélen ül, eláll a 
rövid torzsavirágzattól (ENCKE, 1987). Bogyótermése éréskor sárgás-narancssárgás színü (ROHWER, 2002).

Előfordulása: Kolumbiában sok populációja él a Cauca-völgyben és a Río Magdalenavölgyben, ahol az erdei vízfolyások mentén közönséges növény. 200 és 1500 méter közötti tengerszint feletti magasságon fordul elő (CARDONA, 2004).

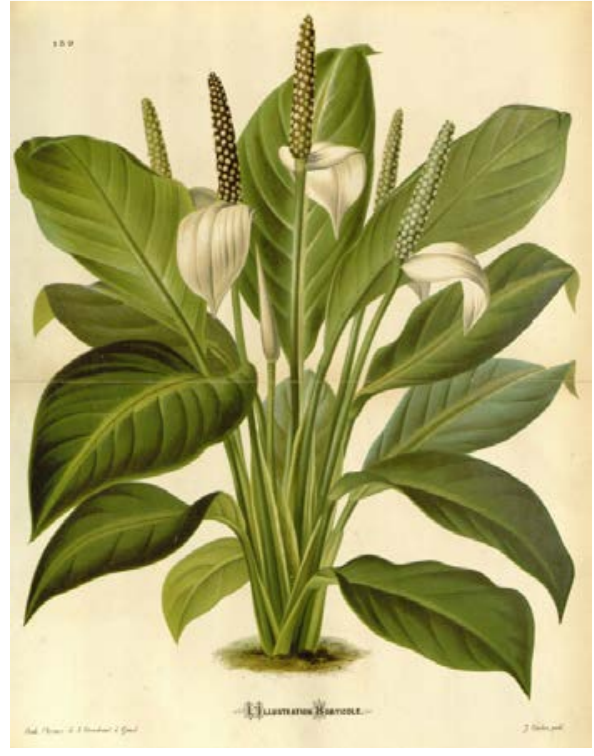

4. ábra. Spathiphyllum floribundum (Forrás: Wikimedia, Licensz: public domain).

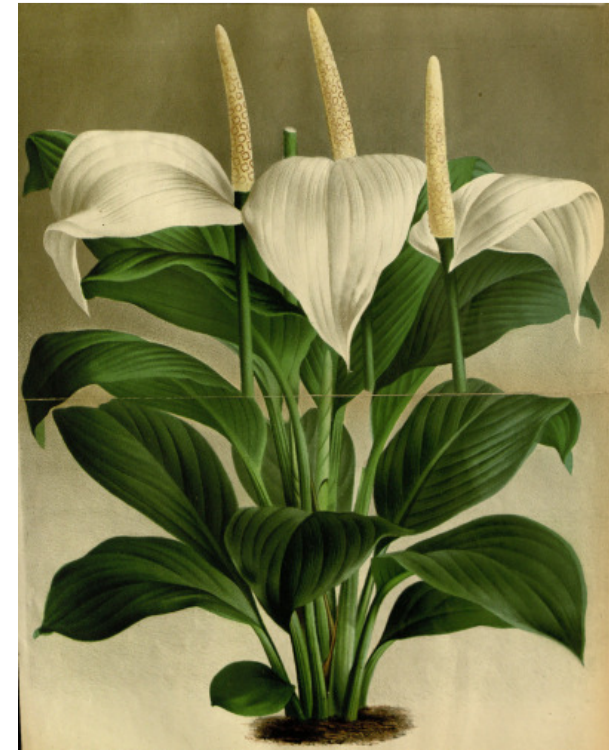

5. ábra. Spathiphyllum cannifolium (Forrás: Wikimedia, Licensz: public domain).

\subsubsection{Spathiphyllum cannifolium (Dryand.) Schott}

Hosszú levélnyeleken helyezkednek el világoszöld börnemü levelei, melyek kevésbé erezettek az előző fajokhoz képest. A spatha általában visszahajló, belső része fehér, kívül zölddel mosott (5. ábra). A spadix fehér, esetleg halvány szürkészöld (ROHWER, 2002).

A legelterjedtebb faj Kolumbiában, az Amazonas medencéjében fordul elő, 200 és 1000 méter közötti tengerszint feletti magasságon. Egész évben virágzik (CARDONA, 2004).

\subsubsection{Spathiphyllum phryniifolium Schott}

Erösen erezett levelei lándzsásak és hosszúkás-elliptikusak, sötétzöldek, 12-60cm hosszúak, 4-22 cm szélesek. A spatha halvány sárgászöld, krémszínü, $25 \mathrm{~cm}$ hosszú, csónak alakú. A spadix 2-8 cm hosszú, 8-15 mm széles fehér, virágnyíláskor aranysárgára színeződik. A termés 2 hónap alatt érik be. A növény magassága meghaladhatja az 1 métert is.

Többnyire vízfolyások mentén fordul elő, a virágzása március és szeptember közé tehető. Costa Ricában és Panamában fordul elő (CROAT, 1978). BAKER et BURGER (1976) szerint ritka Costa Ricában, annak ellenére, hogy több forrás sugallja gyakori előfordulását.

\subsubsection{Spathiphyllum friedrichsthalii Schott}

Robusztus termetü, gyakran 1 métert is meghaladó akauleszcens faj. Nagyobb csoportjai tenyésznek sekély vízben. A levélnyél 30-60 cm hosszú, a levélhüvely a nyél felénél is tovább 
tarthat. A levéllemez keskeny elliptikus, mindkét vége elkeskenyedik, 28-70 cm hosszú, 7-22 cm széles, jól látható erezettel (6. ábra). A virágzat egy magasságban helyezkedik el a levelekkel. A spatha csónak alakú, többé-kevésbé elliptikus, és valamelyest aszimmetrikus, 13-32 cm hosszú, 5-11 cm széles, virágzás közben fehér, a föér kivételével, ami zöld. Terméséréskor az egész spatha bezöldül. A spadix hengeres, tompa végü, fehér, 3-7 cm hosszú, kevesebb, mint $2 \mathrm{~cm}$ széles. Terméséréskor a színe zöldre változik. A tojás alakú termésében 2-11 db szabálytalan mag található, megérve barna színű, $4 \mathrm{~mm}$ hosszú. Egész évben virágzik. Az illatát távolról is érezni lehet, Trigona méhek gyakran látogatják. Előfordulása: Nicaragua, Kolumbia, Panama (CROAT, 1978). Kolumbiában a kertészeti piacon előfordul mint dísznövény, a helyiek a kertjükbe is ültetik (CARDONA, 2004).

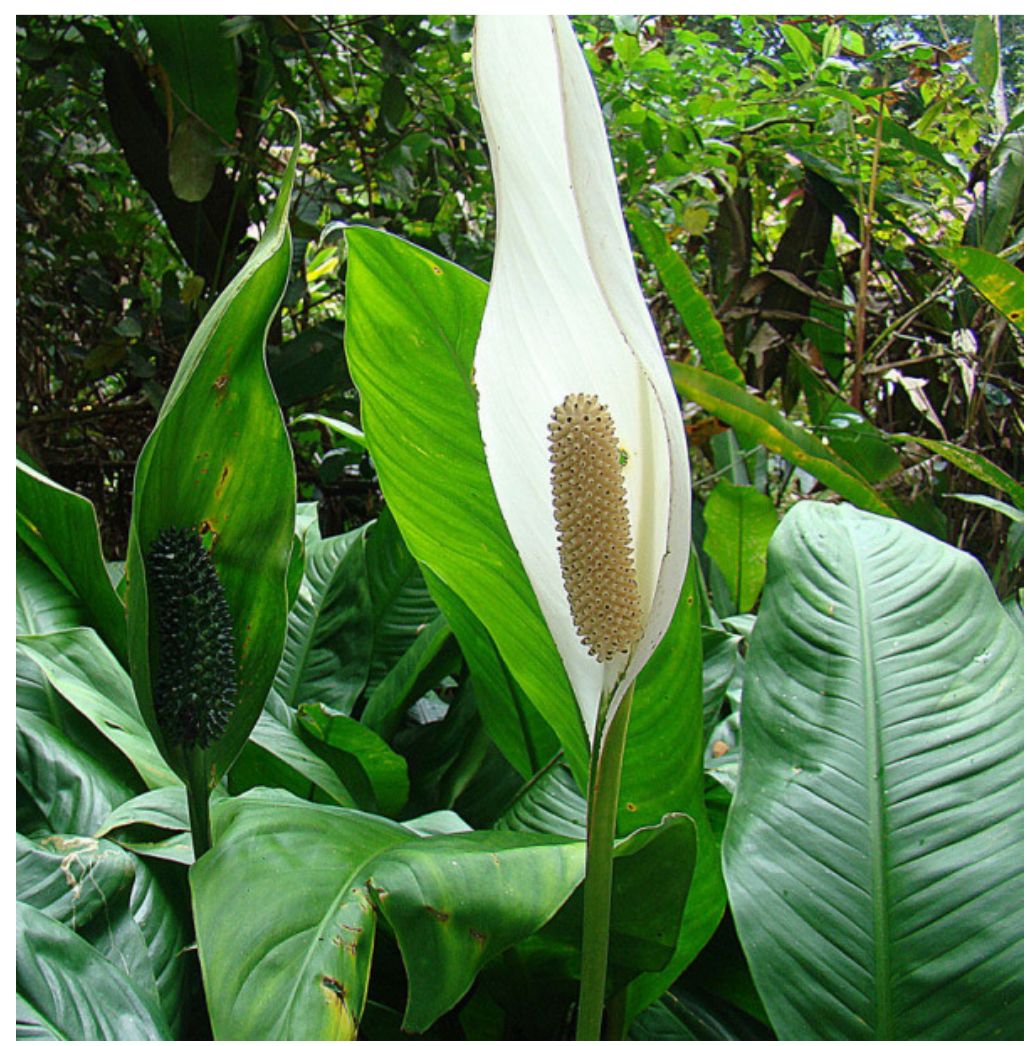

6. ábra. Spathiphyllum friedrichsthalii (Forrás: Dick Culbert, Licensz: CC BY 2.0).

\subsubsection{A termesztett alapfajok és kertészeti hibridek környezeti igényei}

A Spathiphyllum fajok többsége esőerdei humuszlakó növény, leggyakrabban folyó víz közelében, nagy kolóniákat alkotva élnek, előfordulásuk Kolumbiában 1300 méteres magasságig jellemző (CARDONA, 2004), így a kertészeti hibridek termesztés- és tartásbeli környezeti igénye is a fajok eredeti élőhelyének megfelelően alakul.

\subsubsection{Höigény}

A Spathiphyllum hibridek melegigényes növények. Nappal $18-32{ }^{\circ} \mathrm{C}$ közötti, éjjel $21-$ $24{ }^{\circ} \mathrm{C}$ közötti hőmérsékleten nevelhetőek (BEYTES et HAMRICK, 2003). A szaporítóanyag- 
neveléshez (magonc, vagy akklimatizált in vitro növények) a $22-24{ }^{\circ} \mathrm{C}$ az optimális, becserepezéskor elegendő a $20{ }^{\circ} \mathrm{C}$, később $18{ }^{\circ} \mathrm{C}$-ig lemehet a hőmérséklet (RÖBER et al., 1994). A legalacsonyabb tolerált minimumhőmérsékletről eltérően nyilatkoznak a források: $18{ }^{\circ} \mathrm{C}$ (HERZ, 1976), $16^{\circ} \mathrm{C}$ (MÁNDY et al., 2006), $15^{\circ} \mathrm{C}$ (HERWIG, 1976), ideiglenesen $7{ }^{\circ} \mathrm{C}$ (BEYTES et HAMRICK, 2003), de a fagyot még rövid ideig sem türi lombkárosodás nélkül. A túl magas hőmérséklet $\left(26{ }^{\circ} \mathrm{C}\right.$ feletti) késlelteti a virágzást (HENDRIKS et SCHARPF, 1988). McCONNELL et al. (2003) vizsgálata szerint a $29{ }^{\circ} \mathrm{C}$ feletti rendszeres (napi 12 óra) termesztési hőmérséklet már a vegetatív növekedést tekintve is hátrányos következményekkel jár, ugyanígy a másfél óránál tovább tartó $45^{\circ} \mathrm{C}$-os extrém felmelegedés. A magas hőmérséklet hatására a növények keskenyebb leveleket fejlesztenek. A vizsgált fajták között találtak azonban eltéréseket a magas hőmérsékleti tolerancia tekintetében, ez alapot adhat célzott fajtanemesítésre.

\subsubsection{Fényigény}

A Spathiphyllum hibridek kevésbé fényigényesek, elsősorban a szórt fényt kedvelik. Általában tavasszal virágoznak, augusztustól decemberig ritkán, nappalhossz-közömbös növények (HENNY, 1986). OYAERT et al. (2003) szerint viszont nem zárható ki, hogy a virágzást a fényellátás és a hőmérséklet bizonyos kombinációja váltja ki. Spathiphyllum 'Alfa' fajtán végzett megfigyeléseik szerint a virágzást a rövid nappal ( $<12$ óra) fakultatívan elősegítette, és a legtöbb növény akkor kezdett virágozni, amikor a hőmérsékletet nem engedték magasabbra $24{ }^{\circ} \mathrm{C}$-nál. A fotóperiódus hatását azonban a fényintenzitás befolyásolta, így valószínűleg a fényösszeg is szerepet kap a virágzás indukciójában. További eredményeik szerint a vegetatív növekedésre csak a fényösszeg van hatással; a legnagyobb vizsgált fényösszeg (16

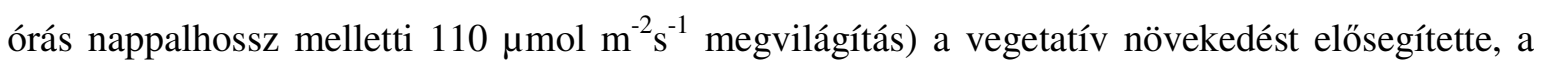
virágzást csökkentette (azonos hőmérséklet mellett). HEEMERS et al. (2003) összevetette az 'Alfa' és 'Cervin' fajtákat a virágzásindukció szempontjából. Igazolták OYAERT et al. (2003) eredményeit az 'Alfa' fajtával kapcsolatban, hogy a hőmérsékletnek $26^{\circ} \mathrm{C}$ alatt kell lennie a virágzás bekövetkeztéhez, és a rövid nappal elősegíti azt. Ezen indukáló feltételek mellett az 'Alfa' a növény vegetatív tömegétől függetlenül generatív fázisba lép. Ellenben a 'Cervin' fajta virágindukciója nem kapcsolódott ezekhez a tényezőkhöz közvetlenül: kizárólag egy bizonyos vegetatív tömeg elérésekor indult meg.

Mérsékelt égövön, a hibridek és alapfajok növényházi termesztése során nem szükséges árnyékolni az állományt a téli időszakban, nyáron viszont permanens vagy mozgóárnyékoló segítségével 15-20 klx közé kell csökkenteni a megvilágítottság mértékét. Az ennél nagyobb fényintenzitás a levelek sárgulásához, kivilágosodásához vezet, illetve napégést okozhat. Fényhiány hatására viszont a növények megnyúlt levélnyelet és virágzati szárat fejlesztenek, a levéllemez sötétzöld lesz, mérete megnő és a virágzás szegényesebb (RÖBER et al., 1994). 
BEYTES et HAMRICK (2003) szerint az elfogadható megvilágítás tartománya 8,6-27 klx közé esik. Kiválóan tolerálja ugyanakkor a fényszegény körülményeket (MÁNDY et al., 2006), ami gyakorta jellemzi az irodákat és lakótereket.

\subsubsection{Viz-és páraigény}

Folyamatosan és egyenletesen nedves közeget igényel a termesztés során végig, és viszonylag jól tolerálja a túlöntözést, bár hosszú ideig ilyen körülmények között tartva jelentősen megnő a hervadást és gyökérrothadást okozó betegségek kockázata (BEYTES et HAMRICK, 2003). Hidrokultúrás nevelésre alkalmas (HEITZ, 1997; RÖBER et al., 1994). Álvízinövényként, rövid ideig tartó (néhány hónapos) akváriumi tartásra is értékesítik (SAHIDIN, 2011). A 80\%-os, esetleg magasabb relatív páratartalom javasolt az egész kultúra során, az egyenletes vízellátást pedig legkönnyebben csöpögtető vagy ár-apály rendszerü öntözéssel lehet megvalósítani (RÖBER et al., 1994).

\subsubsection{Talaj- és tápanyagigény}

Jól drénezett, de jó víztartó kapacitású közeget igényel. Az USA-ban általában 1:1:1 arányú tőzeg, perlit, kéreg keveréket használnak a termesztéséhez, Európában durvára darált tőzeget (BEYTES et HAMRICK, 2003). RÖBER et al. (1994) szerint a közeg minimum 20\% levegőkapacitással rendelkezzen; 20-30 v/v\% Styromull (habosított polisztirolgolyó) vagy perlit bekeverése segíti a gyökérfejlődést. A közeg pH-ja 5,8-6,5 közé essen (BEYTES et HAMRICK, 2003; MÁNDY et al., 2002).

Tápanyagigényes kultúra, 3:1:2 N-P-K arányban igényli a makrotápanyagokat (BEYTES et HAMRICK, 2003). A közeg oldható sótartalma elektromos vezetőképességben („EC”) kifejezve optimális esetben $2 \mathrm{dS} / \mathrm{m}$ (CHEN et al., 2003). A növények össznitrogénigénye cserepenként és évente $600 \mathrm{mg}$, a közegbe kevert alaptrágya (70-140 mg N, 50-100 mg $\mathrm{P}_{2} \mathrm{O}_{5}$, 100-200 mg K $\mathrm{K}_{2} \mathrm{O}$, 30-60 mg Mg, összesen 0,5-1 g vízoldható só a közegben literenként) mellett 0,05-0,1\%-os folyékony tápoldatozást igényel hetente. A 700 vpm-es $\mathrm{CO}_{2}$ trágyázás jobb minőségü növényeket eredményez (RÖBER et al., 1994).

\subsubsection{Jelentőség, felhasználás}

A Spathiphyllum fajok és hibridek leginkább dísznövényként ismertek. Korábban a nemzetség egyes fajait (pl S. cannifolium, S. wallisii) dekoratív virágzatuk miatt üvegházakban nevelték (DANERT et al., 1981), ma leginkább hibrid formákkal találkozunk a kereskedelemben (HEITZ, 1997). Népszerüségüket a könnyü termeszthetőségüknek (az Anthurium taxonoknál könnyebben termeszthetők), időzíthetőségüknek (a fajták jó része bármikorra virágoztatható gibberellines kezeléssel (CHEN et al., 2002a) és a kiváló lakástürő képességüknek köszönhetik (SCHMIDT, 2002). Gyakorlatilag bármilyen fütött beltéri helyiségben megmaradnak, és 
többnyire virágoznak is, amennyiben szórt fényben részesülnek (BEYTES et HAMRICK, 2003). A Spathiphyllum hibridek azon növények közé tartoznak, melyeknél célzott kutatási eredményekkel alátámasztották, hogy megszürik a beltéri helyiségek levegőjéből a formaldehidet, benzolt és egyéb illékony szerves vegyületeket, melyek a felhasznált burkolóanyagokból és bútorokból származnak (LIU et al., 2007). Bár az eddig vizsgált közel 120 növényfaj közül nem a Spathiphyllum hibridek a leghatékonyabbak ilyen téren, de könnyü elérhetőségük és alkalmazhatóságuk miatt mégis velük kapcsolatban végezték a legtöbb kutatást (SOREANU et al., 2013).

Eredeti élőhelyükön a helyi lakosság egyéb célra is felhasználja ezeket a növényeket: Kolumbiában és Venezuelában a $S$. cannifolium virágzatával dohányt illatosítanak, KözépAmerikában pedig a $S$. cochlearispathum leveleiböl ízületi bántalmak elleni gyógyszert készítenek. A S. friedrichstalii, a $S$. phryniifolium és a $S$. matudae fiatal virágzata (,huisnay”) élelmiszernövényként is szolgál: tojással megfözve (DANERT et al., 1981), vagy ecetben savanyítva (BUNTING, 1960) fogyasztják.

\subsubsection{A Spathiphyllum hibridek piaci helyzete}

Míg 1980-ban csak 6 fajta volt termesztésben, jelenleg több mint 50. Az új fajtákat hagyományos nemesítéssel és in vitro állományokból származó rügymutánsokból állítják elő (CHEN et al., 2002a).

Holland adatok szerint (VAN DEN BERG, 2002, 2003, 2004, 2007, 2008, 2009, 2010) a Spathiphyllum taxonok népszerüségét jól jelzi, hogy évek óta a 7-10. helyet foglalják el a cserepes szobanövények piacán a forgalmi értéket tekintve. A forgalmazott mennyiség a kis ingadozásoktól eltekintve az elmúlt évtizedben gyakorlatilag alig változott az egyes években, csakúgy, mint a növény átlagára (7. ábra).

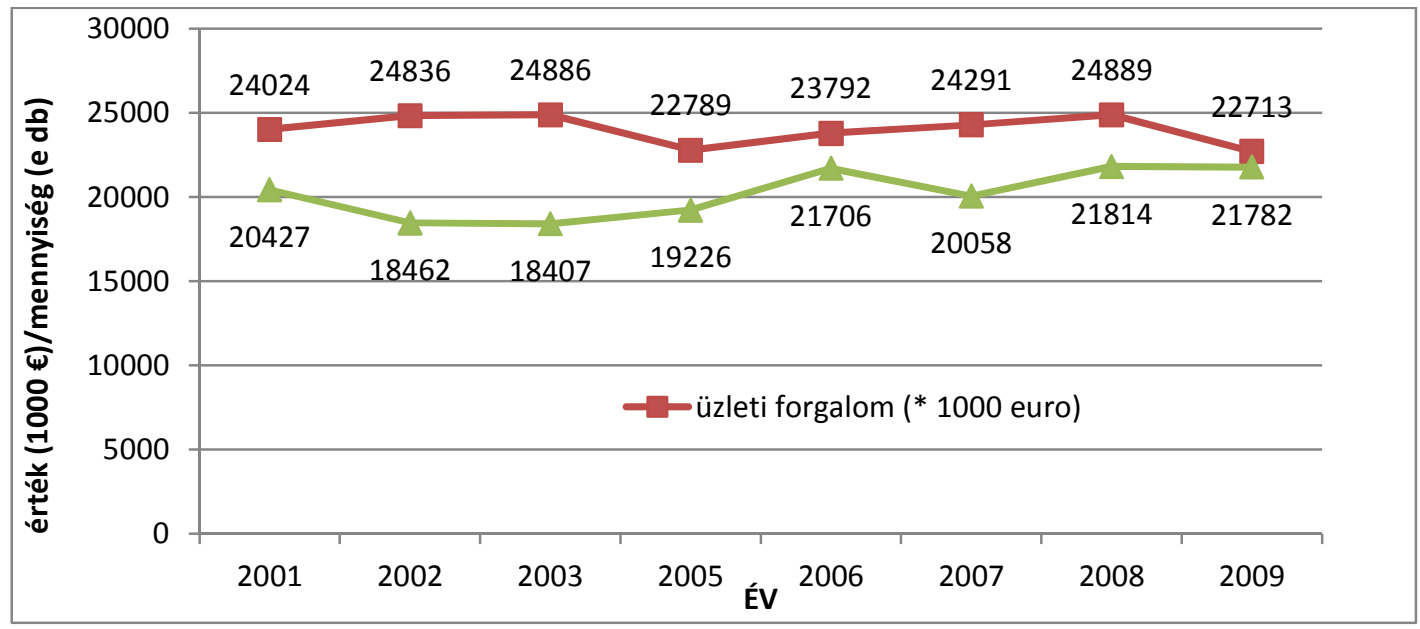

7. ábra. A Spathiphyllum taxonok forgalmi adatai 2001-től 2009-ig, forgalmazott mennyiség. 
A legnépszerübb fajták első három helyén gyakorlatilag az elmúlt évtizedben ugyanaz a három fajta szerepel ('Chopin', 'Sweet Chico', 'Quatro'), a 4. és 5. helyért folyik a verseny felés letünő fajtákkal (8. ábra).

Az egyes fajták nagykereskedelmi átlagára ugyan évente változik a forgalmi mennyiség és egyéb piaci tényezők függvényében, de általánosságban stabilnak mondható (9. ábra). A közepes és kis termetü fajták átlagára 0,5-1,5 €/db, a nagytermetü fajták (pl. 'Sensation', 'Jumbo') átlagára egy nagyságrenddel nagyobb tartományban mozog, 5-15 €/db.

Az eladások fellendítése céljából a holland termesztőket tömörítő szövetségek kidolgoztak egy új marketingkoncepciót, „Air So Pure” névvel. Ebbe a Spathiphyllum hibrideket is bevonták, alapozva azon tulajdonságukra, hogy képesek a lakás és iroda beltéri levegőjében a káros szerves anyagok koncentrációját csökkenteni (COLLINS, 2009).

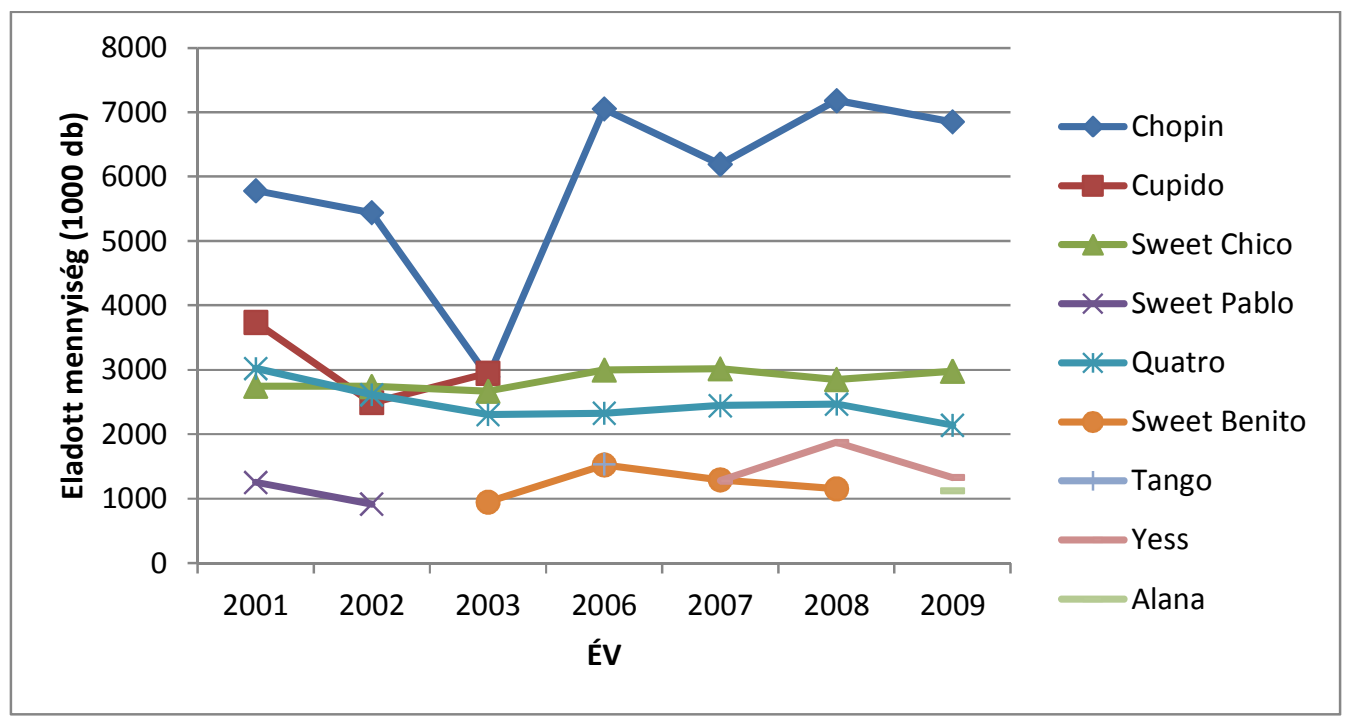

8. ábra. Az évente 5 legnépszerủbb Spathiphyllum fajta eladott mennyiségének változása.

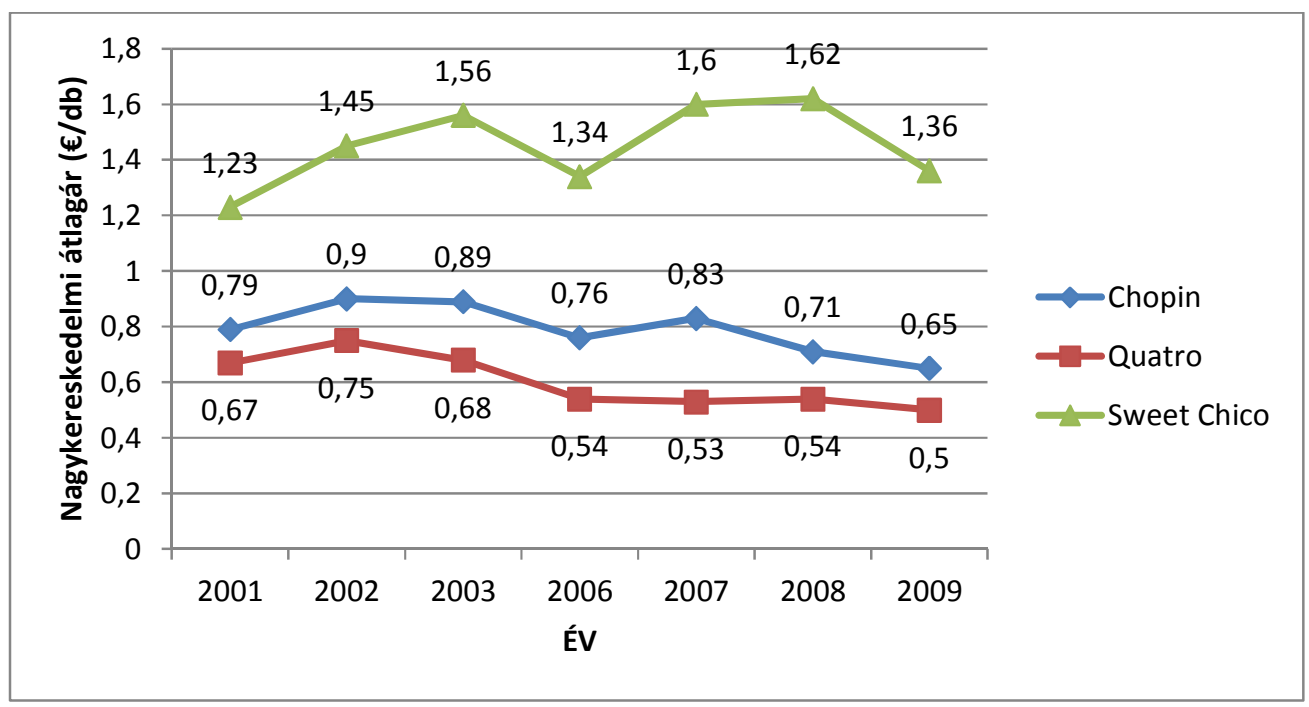

9. ábra. A három legnépszerübb Spathiphyllum fajta árának alakulása 2001-2009 között. 


\subsubsection{Fajták}

A fajták közötti fö különbség felhasználói szemmel elsősorban a méretük, kisebb mértékben a lombozat habitusa és textúrája. A jelenlegi kínálatban a kisméretü fajtáktól kezdve (25 cm magas), az egész hatalmasokig $(120-150 \mathrm{~cm}$ ) előfordul minden változat (CHEN et al., 2003).

- $\quad$ 'Annette' - Kecses habitussal, fényes, sötétzöld levélzettel rendelkezik.

- $\quad$ 'Calypso' - Tompa csúcsú, hullámos levelei vannak.

- ‘Ceres' - Sürün álló, középzöld levelekkel rendelkezik.

- $\quad$ 'Chopin' - Az egyik legkisebb termetü fajta, a buroklevél teteje zöld, a torzsa igen kicsi.

- 'Cody's Color’ - Kisebb levelek és rövidebb virágszár jellemzi.

- ‘Cupido’ - Szökőkútszerüen szétterülő habitusa, burkolt torzsavirágzatai vannak.

- ‘Cupido Diamond’ - Tenyészideje rövid, virágzata nagy, erős virágzati szárral.

- ‘Cupido Tango’ - Sötét levélzetü, bőségesen ontja a virágokat.

- $\quad$ 'Crystal Cupido' - Sötét lombú, erőteljes virágzati szárakon nagy buroklevelei vannak.

- $\quad$ 'Debbie' - Közepes termetü, széles levelekkel rendelkezik.

- 'Del Rio' - Nagyon széles habitusa és alacsonyan növő virágzatai vannak.

- $\quad$ 'Deneve' - Alacsony, de széles habitus, esetenként zöld buroklevél jellemzi.

- $\quad$ 'Domino' - Fehértarka levélzetü, az egyetlen ilyen fajta a piacon (syn. 'Gemini').

- $\quad$ 'Figaro' - Sötét, fényes levélzet, széles buroklevelek jellemzik.

- Flower Power' - Gömb alakú habitusa, zöld és fehér magasra nyúló buroklevelei vannak.

- $\quad$ 'Hi Ho Silver' - A ‘Ceres’ egyik változata, fakó levélerezettel rendelkezik.

- ‘ Jetty’ - Gyorsan növő fajta, sok virágzattal, meglehetősen jól türi a hőingadozást.

- 'Knockout' - Bordázott, szélesen szétterülő levélzet és magas szárú torzsavirágzatok jellemzik.

- $\quad$ 'Lynise' - Közepesen zöld levélzetü és keskeny buroklevelei vannak.

- 'Mauna Loa Supreme' - Nagy termetü (90 cm magas), 18-20 cm-es buroklevelekkel rendelkezik.

- $\quad$ 'Novo’ - Robusztus termet és sötétzöld levelek jellemzik.

- 'Pablo' - Olajzöld levélzetü és buroklevelei oválisak.

- $\quad$ 'Patrice' - Laza habitusú, virágszárai eltérő méretủek.

- $\quad$ 'Petite' - Tömött, kompakt habitusú. 
- $\quad$ 'Piccolino’ - Sötétzöld levélzet, korai virágzás jellemzi.

- $\quad$ 'Power Petite' - Sürü növekedésével kis tartókba ideális.

- $\quad$ 'Sensation-Mini' - Hasonló, mint a 'Sensation’ fajta, csak kisebb méretü.

- $\quad$ 'Sensation' - Hatalmas, sötétzöld, bordázott levelekkel elérheti a 120 cm-t.

- $\quad$ 'Sonya' - Extrém kompakt habitussal rendelkezik.

- 'Starlight' - Sötét, lándzsás levelek és erős virágzati szárak jellemzik.

- $\quad$ 'Sunlight' - Tömött és erőteljes habitusú, buroklevelei zöldülő végüek.

- $\quad$ 'Supreme' - Igen keresett fajta, sötét levélzettel, buroklevele akár 18 cm-es.

- 'Sweet Benito' - Jól sarjadzik, levelei sötétek és fényesek, kompakt habitussal, hosszan virágzik, a levelek jól türik az erős fényt.

- $\quad$ 'Sweet Chico’ - Fényes zöld levelei vannak rövid levélnyélen, tömött habitusú, jól csomagolható. Jól időzíthető a virágzása gibberellines kezeléssel.

- $\quad$ 'Sweet Pablo’ - Gyorsan növő fajta, folyamatosan virágzik.

- ‘Taylor's Green’ - Mélyzöld és lekerekített levelekkel rendelkező fajta.

- $\quad$ 'Ty's Pride' - A nagy torzsavirágzatok a sötétzöld levélzetben bújnak meg.

- 'Vicki-Lynn’ - Oszlopos, magasra törö növekedési jellegü.

- 'Viscount' - Gyorsan növő, egész évben virágzó fajta, mélyen bordázott levélzettel.

- 'Viscount Prima' - Fényes levélzet és fölé bástyaként emelkedő fehér buroklevelek jellemzik.

- 'Wallisii' - Papírszerü lándzsás levelei és hasonló alakú buroklevelei vannak.

• Yess' - Feltünően bokros habitusú, nagyon bőven virágzó.

\subsubsection{Termesztés}

Szaporítása történhet magvetéssel, tőosztással és in vitro szaporítóanyag felhasználásával. A magvetés fokozatosan elvesztette jelentőségét a 90-es évek közepére (RÖBER et al., 1994), de a homozigóta fajták megjelenésével új eröre kapott (GEORGE et al., 1993), köszönhetően annak, hogy elkezdődött a kiváló minőségü, ellenőrzött magtermesztés (BEYTES et HAMRICK, 2003). A 'Cupido’ fajtát például kizárólag magvetéssel szaporítják (CHEN et al., 2003), a nagytermetü 'Mauna Loa' fajtát szintén (BEYTES et HAMRICK, 2003). A magvetést az Anthurium fajokéhoz hasonló módon lehet elvégezni (RÖBER et al., 1994). Tőosztással nagyüzemileg már nem szaporítják, a mikroszaporítás a legelterjedtebb szaporításmódja (CHEN et al., 2003).

A termesztők számára a Spathiphyllum kimondottan hosszú kultúra (készáru mérettől függően: 8-10 cm cserépben 3-5 hónap, 15 cm-esben 4-9 hónap, 20 cm-esben 7-11 hónap, 25 
cm-esben 8-12 hónap, 36 cm-esben 12-20 hónap), aminek nagy a fütésigénye, ezért főként a melegebb klímájú vidékeken termesztik, majd szállítják a fogyasztói piacokra (BEYTES et HAMRICK, 2003).

A növekedésszabályozás fontos szerepet kap a termesztéstechnológiában. A Spathiphyllum hibrideknél, ahogy az Araceae család más tagjainál is, egyszeri gibberellinkezeléssel virágzásindukciót lehet előidézni (HENNY, 1981). A Spathiphyllum ugyan rendszeresen virágzik, ha elérte az adult állapotot, ez többnyire azonban tavaszra esik (januáraugusztus között). Ahhoz, hogy egész évben virágzó terméket lehessen értékesíteni, illetve nem adult, kisméretü példányoknál is indukálják a virágzást, a gyakorlatban gibberellines kezelést alkalmaznak (CHEN et al., 2003; BEYTES et HAMRICK, 2003). Ennek módja, hogy a tervezett értékesítés előtt 8-15 héttel 150-250 ppm koncentrációjú levélpermetezést végeznek. A kezelés időpontja évszak- és fajtafüggő (BEYTES et HAMRICK, 2003). CHEN et al. (2003) vizsgálata szerint elegendő a 100 ppm-es kezelés is, és ez nem csak időzíti a virágzást, hanem javítja is a virágzatok minőségét. A kezelés után 9-12 héttel várható a virágzás megindulása. A GA 3 kezelés hátránya, hogy nem mindegyik fajta reagál rá megfelelően, ezt a termesztőknek tesztelniük kell megfelelő adatok hiányában (BEYTES et HAMRICK, 2003). Egyes fajták sok, kisebb méretü, torzult virágzatot, megnyúlt virágzati szárat és keskeny leveleket nevelnek a kezelés hatására (HENNY, 1981; VISSERS et HALEYDT, 1994). A másik gyakran alkalmazott növekedésszabályozó kezelés a növények bokrosítása BA-nel. Mivel a kisebb méretü fajtákat gyakran nem adult állapotban értékesítik, ezért azoknak nincs idejük megfelelöképp besürüsödni. Ezt 250-1000 ppm koncentrációjú BA kezeléssel helyettesítik. A kezelést még a tálcás állapotú szaporítóanyagnál végzik el levélpermetezés formájában, de feltétlenül a begyökeresedés után, mert a BA gátolja a gyökérképződést (BEYTES et HAMRICK, 2003).

\subsection{A Spathiphyllum hibridek mikroszaporítása}

Az első publikációk a Spathiphyllum taxonok mikroszaporítási lehetőségeiről a hetvenes évek végén jelentek meg (KUNISAKI, 1977; FONNESBECH et FONNESBECH, 1979). Az első fajtacsoportok 1983-as megjelenésével (Bock klónok) pedig szinte teljesen visszaszorult a generatív szaporításuk. Bő egy évtized múlva azonban, a magról vethető homogén állományt adó hibrid fajták elterjedésével a vegetatív szaporítóanyag-piaca összeomlott (GEORGE, 1993), mára azonban ismét megjelentek a kínálatban vegetatív (in vitro) szaporítóanyagról nevelt fajták. Amíg az 1970-es években csak két fajtát termesztettek az USA-ban, addig az ezredfordulóra a termesztésben lévő fajták száma meghaladta az 50-et (HENNY et CHEN, 2010). 2008-ban elérte az évi 27 milliót az in vitro előállított szaporítóanyag Spathiphyllum fajtákból. A fajták gyors bevezetését is lehetővé teszi az in vitro történő szaporítóanyag-előállítás. A hagyományos 
szaporítás mellett 5-7 évre van szükség ahhoz, hogy kellő mennyiség álljon rendelkezésre egy új fajtából a piacra lépéshez, ezt azonban 2-3 évre csökkenti a mikroszaporítási technológia. Emellett pedig az in vitro előállított szaporítóanyag mentes a fertőzésektől, a technológia révén jóval kevesebb a helyszükséglet a termesztőberendezésekben, hiszen nem kell anyanövényállományt fenntartani, és az egyenletes minőségü szaporítóanyagot a termesztők egész évben bármikor megvásárolhatják (CHEN et HENNY, 2008). A legtöbb szerző hajtáskultúrát használ a Spathiphyllum szaporításához (lsd 3.2.2.1 fejezet), mert az Araceae család növényeinél a kallusz fázison keresztüli (indirekt) organogenezis gyakorta vezet szomaklonális variabilitás fellépéséhez (CHEN et HENNY, 2006). A szomatikus embriókultúrákkal is foglalkozott néhány szerző (lsd 3.2.2.2 fejezet), hiszen ezzel a módszerrel jóval nagyobb mennyiségü szaporulatot lehet előállítani, mint a hajtáskultúrával, ezenkívül sokkal alkalmasabb bioreaktor rendszerü tenyésztéshez, mint a hajtáskultúrák (PAEK et al., 2001). A továbbiakban a mikroszaporítási technológia fázisainak megfelelően tárgyalom az irodalomban fellelhető információkat.

\subsubsection{Előkészítő és indító fázis}

FONNESBECH et FONNESBECH (1979) a korábbi források hiánya miatt kultúraindításnál a szóba jöhető növényi explantátumokat mind kipróbálta a 'Clevelandii' fajtánál: levéldarabokat, a torzsavirágzatot, virágzati tőkocsányt, szárdarabokat, a hajtáscsúcsot és a szár oldalrügyeit. A fertőtlenítés előtt a felesleges részeket eltávolították, az explantátumokat pedig folyó csapvizes mosással tisztították. A fertőtlenítéshez az explantátumokat először 70 \%-os alkoholba mártották, majd 2 \%-os NaOCl-oldatban áztatták 15 percig, végül 0,2 \%-os NaOCl-oldatban öblítették és hagyták a kimetszésig. A leveleket $1 \times 1$ cmes darabokra, a torzsavirágzatot 2 mm-es szeletekre vágták (majd utána négyfelé), a virágzati tőkocsányt 2-3 mm-es szeletekre, a szárat pedig szintén 2-3 mm-es darabokra szeletelték, de csak a belső részeit használták fel kivágás után. A szárról mind a hajtáscsúcsot, mind az oldalrügyeket felhasználták. Az indítótáptalajok 3 auxin és 3 citokinin különböző kombinációit tartalmazták. Sem a levéldarabokból, sem a virágzati szárból nem sikerült regenerációt elérniük. A virágzati explantátumokból kisszámú sarj fejlődését figyelték meg 6 vagy több hónap elteltével nagy hormonkoncentrációk mellett (10 $\left.\mathrm{mgL}^{-1} \mathrm{PBA}\right)$, azonban a legtöbb sarjat a rügyek és szárdarabok inokulálásából nyerték (szintén $10 \mathrm{mgL}^{-1} \mathrm{PBA}$ mellett).

DINIZ et al. (2008) szárdarabokból történő kultúraindításnál a fertőtlenítéshez szintén elegendőnek találták az 1 perces $70 \%$-os etanolba bemártást kombinálva 10 perces Cahipokloritos kezeléssel. A szárdarabokat meghámozták inokulálás előtt. A fertőtlenítési eljárásukkal 73\%-os sterilitást értek el. Azokban a hivatkozásokban, amelyek nem tesznek említést a szárdarabok meghámozásáról, sokkal összetettebb és erősebb fertőtlenítési eljárásokat 
alkalmaztak: RAMIREZ-MALAGON et al. (2001) etanolos bemártást, 20 perces hipokloritos fürdőt, és gombaölőszeres kezelést $\left(2 \mathrm{gL}^{-1}\right.$ benomil) ír le, KAÇAR et al. (2005) pedig 10 perces 0,05\%-os higany(II)-kloridos kezelést, etanolos bemártást, kétszer ismételt 10 perces $10 \%$-os hipokloritos fürdőt. Utóbbi szerzők 90 \%-os sterilitást értek el szárdarabok felhasználása során.

A virágzati részek sokkal kevésbé szennyezettek, és enyhébb fertőtlenítési eljárást igényelnek. VARGAS et GARCIA (1997) virágzatból történő kultúraindításhoz elegendőnek találták a 15 perces $1 \%$-os $\mathrm{NaOCl-os} \mathrm{áztatást,} \mathrm{melynek} \mathrm{hatékonyságát} \mathrm{vákuumpumpa}$ használatával növelték, majd ezt követte egy 70 \%-os etil-alkoholos öblítés és táptalajra helyezés. HEGEDÜS (2005) jobbnak tartotta a virágtorzsáról történő kultúraindítást, mert sarjról indítás esetében nagyobb a veszélye az endogén kórokozó jelenlétének - az Araceae család tagjaira általánosan jellemző az endogén baktériumos fertőzés. A zárt bimbó esetében kevésbé szigorú fertőtlenítési eljárást javasol - 2-3 \%-os fertőtlenítőszeres (hipokloritos) mosást 30 percig, 96 \%-os etanolba mártást, majd lelángolást. Elnyílt, lezöldült virágtorzsa esetén viszont felületi mosást követően 24 órás áztatást ajánl $1 \mathrm{gL}^{-1}$ neomicin-szulfát, $2 \mathrm{gL}^{-1}$ benomil, $3 \mathrm{mgL}^{-1}$ malachitzöldből készült oldatban. Ezután kereskedelmi töménységü hypoban 3 perces áztatást, majd háromszori steril desztillált vizes öblítést javasol.

Az indítótáptalajok összetételére jellemző, hogy szárdarabok, rügyek inokulálása esetén kisebb, 1-2 mgL $\mathrm{mL}^{-1} \mathrm{BA}$ koncentrációt írnak le a szerzők, auxin nélkül, vagy kis mennyiségü auxinnal (0,1-0,5 $\mathrm{mgL}^{-1}$ IES) kiegészítve, melyekből 1-3 hónap elteltével érhető el sarjregeneráció (DINIZ et al., 2008; JINSHU, 1989; RAMIREZ-MALAGON et al., 2001). WU (2001) Spathiphyllum floribundum hajtáscsúcsot indított különböző hormonkoncentrációjú MS táptalajon. A legalkalmasabbnak az 1,5-3,0 mgL $\mathrm{mg}^{-1} \mathrm{BA}+0,5-1,0 \mathrm{mgL}^{-1} \mathrm{NES}$ kiegészítésü táptalajokat találta, amelyeken 90\%-os volt a regenerálódási arány. Nagy citokininkoncentrációt javasolnak viszont torzsavirágzat inokulálásához: $10 \mathrm{mgL}^{-1}$ PBA (FONNESBECH et FONNESBECH, 1979), $10 \mathrm{mgL}^{-1}$ BA (VARGAS et GARCIA, 1997), $5 \mathrm{mgL}^{-1} \mathrm{BA}+10 \mathrm{mgL}^{-1}$ 2-iP (HEGEDÜS, 2005), melyekből csak 3-6 hónap elteltével várható a regeneráció megindulása. VARGAS és GARCIA (1997) a sarjak mellett kalluszt is kaptak, ők a $10 \mathrm{mgL}^{-1}$ BA mellé ugyanis még $10 \mathrm{mgL}^{-1} \mathrm{NES}-\mathrm{t}$ is adtak a táptalajhoz.

A 1. táblázat összefoglalja a különböző szerzők által leírt fertőtlenítési eljárásokat, a felhasznált táptalajt, valamint a kultúraindítás eredményét Spathiphyllum taxonok esetén. 
1. táblázat. Összefoglaló táblázat Spathiphyllum fajok és fajták indítása során alkalmazott előkezelési és fertőtlenítési eljárásokról, az indító táptalaj típusáról, növekedésszabályozó tartalmáról és az indítás eredményéröl szerzőnként feltüntetve

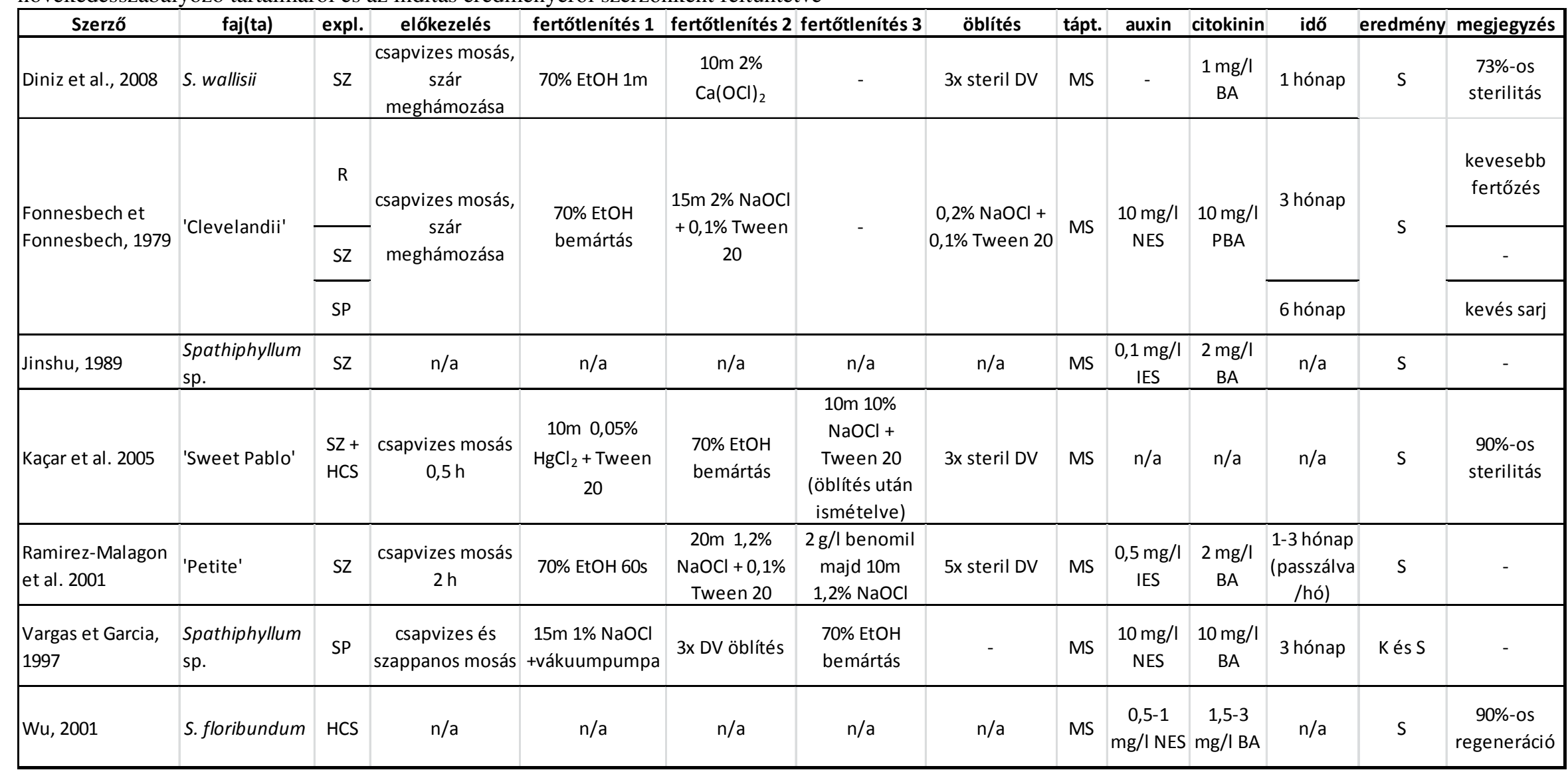

Jelmagyarázat:

expl. - explantátum (HCS - hajtáscsúcs, R - rügy, SP - spadix, SZ - szár),

fertötlenítés (EtOH - etil-alkohol, DV - desztillált víz),

tápt. - táptalaj (BA - benziladenin, IES - indolecetsav, MS - Murashige-Skoog táptalaj, NES - naftilecetsav, PBA - tetrahidropiranil-benziladenin),

eredmény ( $\mathrm{S}-$ sarj, $\mathrm{K}-$ kallusz)

$\mathrm{n} / \mathrm{a}$ - nincs (nem elérhetö) adat 


\subsubsection{Felszaporítási fázis}

A felszaporítási fázisra vonatkozó irodalmi adatokat az alkalmazott regenerálódási útnak megfelelően csoportosítva közlöm és részleteiket a 2. táblázatban foglalom össze.

\subsubsection{Hajtáscsúcskultúra és organogenezis}

FONNESBECH et FONNESBECH (1979) a sikeresen inokulált növényi részeket LS táptalajra helyezték, melyet $30 \mathrm{gL}^{-1}$ szacharózzal és $0,2-2 \mathrm{mgL}^{-1}$ PBA-val vagy kinetinnel egészítettek ki. Megközelítőleg 4 járulékos sarj fejlődését figyelték így meg szubkultúrálásonként. WATAD et al. (1997) 'Petite’ fajtánál vizsgálták és összehasonlították az explantátum növekedését és a sarjsokszorozódást agar tartalmú szilárd táptalajon és folyékony táptalaj felületén úsztatott membrános rendszerben. 25 napos tenyésztés után nagyobb frisstömeget és nagyobb mértékü sarjsokszorozódást tapasztaltak a membrános rendszer esetében. A sarjak száma a 25. napon érte el a maximumot, és a 40. napig (a tenyésztés végéig) már nem emelkedett tovább, szemben a frisstömeggel. A membrános rendszerben nevelt növények több gyökeret is növesztettek. DABSKI et KOZAK (1997) a 2-iP hatását vizsgálták 0,$1 ; 0,5 ; 2 ; 5 ; 10 \mathrm{mgL}^{-1}$ koncentrációban IES-val kombinálva 0,$1 ; 0,5 ; 2$ és $5 \mathrm{mgL}^{-1}$ koncentrációban a sarj- és hajtásregenerációra. A kísérletbe bevont fajta a 'Svend Neilson' volt. A 2-iP koncentráció növelésével a növényeken fejlődő sarjak ill. a sarjtelep frisstömege is nőtt, a legjobb eredményt a $10 \mathrm{mgL}^{-1} 2$-iP $+0,1 \mathrm{mgL}^{-1}$ IES mellett kapták. VARGAS et GARCIA (1997) az indító táptalajon nyert sarjakat $2 \quad \operatorname{mgL}^{-1}$ BA és 0,5 $\mathrm{mgL}^{-1} \mathrm{NES}$ tartalmú táptalajra passzálták, ahol 10,5-es szaporulati rátát értek el, az időtartam viszont nem derül ki. DAS et al. (2000) MS alapú táptalajon, $0,5 \mathrm{mgL}^{-1} \mathrm{BA}, 0,5 \mathrm{mgL}^{-1} \mathrm{BA}$ és NES, $1 \mathrm{mgL}^{-1}$ BA kiegészítéssel szaporítottak Spathiphyllum-ot. 45 nap tenyésztés után az 1 $\mathrm{mgL}^{-1}$ BA kiegészítésü táptalajon kapták a legtöbb sarjat (7-8 db), 0,5 $\mathrm{mgL}^{-1}$ BA mellett NES jelenlétében ill nélküle is átlagban 3-4 sarj fejlődött, minden táptalajon 4 leveles állapotig (2,5-3 cm magasak), kivéve a növekedésszabályozótól mentes MS táptalajon, ahol a növények jóval lassabban fejlődtek. BIHUA (2000) a 'Xiangshui’ fajtát vizsgálta 4 típusú alaptáptalajon BA és NES koncentrációinak 12-féle kombinációjával kiegészítve. A felszaporításhoz a legjobbnak a 2 $\mathrm{mgL}^{-1}$ BA és $0,1 \mathrm{mgL}^{-1}$ NES tartalmú MS táptalajt találta. VARDJA et VARDJA (2001) 3 Spathiphyllum fajtán vizsgálták felszaporítási szakaszban a különböző citokininek hatását és a szubkultúrálások számát a szaporodási rátára. Megfigyeléseik szerint a $2 \mathrm{mgL}^{-1} \mathrm{BA}$ hatására fejlödött a legtöbb sarj az első 3 szubkultúra ideje alatt (egyenként 4-5 hét), majd a negyedik szubkultúra alatt már csökkent a jó minőségü sarjak száma. Ezért a 3. szubkultúrálás után a BA tartalom csökkentését javasolják 0,5-1 $\mathrm{mgL}^{-1}$-re egy vagy két szubkultúra idejére. 
HAN et YAE (2001) LS táptalajon szaporította a 'Cupid' fajtát különböző növekedésszabályozó anyagok jelenlétében. A hajtáscsúcsokat helyezték TDZ és BA tartalmú táptalajokra, amelyek közül a $2 \mathrm{mgL}^{-1}$ BA kiegészítésüt találták a vizsgáltak közül a legjobbnak a járulékos sarjképződés szempontjából. RAMIREZ-MALAGON et al. (2001) szintén a növekedésszabályozók hatását vizsgálták a 'Petite' fajta esetében a sarjszám, sarjméret és sarjtömeg alakulására. MS alaptáptalajt 1;2; $5 \mathrm{mgL}^{-1}$ BA-nel és $0,05 \mathrm{mgL}^{-1} \mathrm{NES}$-sel vagy 0,5; 1 $\mathrm{mgL}^{-1}$ IES-sel vagy 0,$005 ; 0,05 ; 0,1 \mathrm{mgL}^{-1}$ 2,4-D-val egészítették ki. A $0,05 \mathrm{mgL}^{-1} \mathrm{NES}$ kiegészítés mellett minden BA koncentrációban nagyobb sarjszámot mértek, mint a másik két auxin kiegészítés mellett. A legjobb eredményeket a $0,05 \mathrm{mgL}^{-1} \mathrm{NES}+2 \mathrm{mgL}^{-1}$ BA kombináció adta a következők szerint: sarjszám 5,8 db, átlagos frisstömeg 116 mg/sarj, levélszám 14,7 db, oldalsarjak száma 5,3, növényátmérő $14,2 \mathrm{~cm}$, növénymagasság 13,0 cm. Ezen a táptalajon a fejlődött sarjak a növényházi akklimatizálás során is életképesnek bizonyultak. Ha a táptalajhoz $1 \mathrm{mgL}^{-1} \mathrm{KIN}$-t is adtak, $1 \mathrm{mgL}^{-1}$ IES és $2 \mathrm{mgL}^{-1}$ BA mellett, a legnagyobb sarjszám 11,6 db/növény lett, az átlagos frisstömeg pedig $39 \mathrm{mg} / \mathrm{sarj}$ volt. Az eltérő frisstömegű sarjak közül a legalább 20 mm-es magassággal és 66 mg-os frisstömeggel rendelkezők jobbnak bizonyultak a növényházi akklimatizálás során, mint azok, amelyek ezeket az értékhatárokat nem érték el. WU (2001) Spathiphyllum floribundum esetében a járulékos rügyindukcióhoz a legalkalmasabbnak a 0,5-2,5 $\mathrm{mgL}^{-1} \mathrm{BA}+$ 0,5-1,5 $\mathrm{mgL}^{-1}$ NES kiegészítésű MS táptalajokat találta, amelyeken a járulékos rügykihajtásra vonatkozó egy évre vetített szaporodási ráta elérte a 4212-szeres értéket. KAÇAR et al (2005) a Spathiphyllum 'Sweet Pablo' fajtájánál végezték a táptalajban lévő citokinin típusának és koncentrációjának optimalizálását a nagyobb sarjhozam elérése érdekében. A sarjkultúrát MS alaptáptalajon nevelték BA-val, vagy PBA-val kombinálva, kontrolként pedig citokininmentes MS táptalajt alkalmaztak. A szaporodási rátát, a sarjak frisstömegét és átlagos számát mérték. $1 \mathrm{mgL}^{-1}$ BA kiegészítésủ táptalajon a szaporodási ráta az első szubkulturálástól kezdve emelkedett, maximumát a negyedik szubkultárálásnál érte el (8,49 db sarj/növény). Az eredményeik szerint továbbá megállapítható, hogy a PBA szemben a BA-nel jobb citokinin forrásnak tekinthető, hogy egészségesebb és vigorózusabb sarjakat kapjunk, bár drágább, mint a BA. WERBROUCK et DEBERGH (1995) érdekes tapasztalatról számoltak be: 'Petite' fajta felszaporítása során a táptalaj benzil-adenin tartalmát kombinálták imazalillal (IMA), ami szinergista módon erősítette a BA hatását, és erősen megnövelte a növények sarjadzását. Az IMA egy imidazol típusú fungicid, és hasonlóan a triazolokhoz, az ergoszterol bioszintézis gátlásán keresztül fejti ki hatását. $16 \mathrm{mgL}^{-1}$ koncentrációban adva 2,5 $\mathrm{mgL}^{-1} \mathrm{BA}$ mellett 127 sarjat sikerült indukálniuk 10 hét alatt, bár ezeknek a sarjaknak a mérete nagyon kicsi volt. Az IMA kizárólag BA jelenlétében idézte elő ezt a hatást, BA nélkül, csak IMA hatására nem hoztak sarjakat a növények. 


\subsubsection{Szomatikus embriogenezis}

WERBROUCK et al. (2000) közöltek először szomatikus embriogenezisre épülő regenerációs és szaporítási módszert 5 Spathiphyllum fajtánál. Zárt buroklevelü virágzatból fertőtlenítés után kimetszették a portokokat porzószálakkal együtt, majd MS makroelemeket és Nitsch et Nitsch (1969) mikroelemeket, $10 \mu \mathrm{M}$ NES-t és 0,2-3 $\mu \mathrm{M}$ TDZ-t tartalmazó szilárd táptalajra helyezték. A tenyészeteket sötétben nevelték $20{ }^{\circ} \mathrm{C}$-on, így a porzószálakon csoportosan fejlődő szomatikus embriók keletkeztek. Hat hét után az embriókat másodlagos embriók indukálása céljából áthelyezték $10 \mu \mathrm{M}$ BA-t és 0,02 $\mu \mathrm{M}$ NES-t tartalmazó MS táptalajra. Újabb 6 hét elteltével pedig elkezdték a regenerálást 16 órás fotóperiódus mellett $23^{\circ} \mathrm{C}$-on, melyhez a hormonmentes MS táptalajt találták a legjobbnak. Tíz hét alatt nyertek akklimatizálásra alkalmas méretü növényeket. Tapasztalataik szerint minél fiatalabb volt az inokulált porzószál, annál eredményesebb lett a szomatikus embriók kialakulása.

Vegetatív szövetek (levél és levélnyél) felhasználásával elsőként ZHAO et al. (2012) valósítottak meg szomatikus embriogenezist Spathiphyllum 'Supreme' fajtán. In vitro tenyészetből származó növényekről vágtak le leveleket, a levéllemezből $1 \times 1 \mathrm{~cm}$-es, a föeret is tartalmazó darabokat, a levélnyélből pedig $1 \mathrm{~cm}$-es szegmenseket helyeztek el TDZ-vel és 2,4D-vel kiegészített szilárdított MS táptalajra. A keletkező embriók számát négy hónapig $25^{\circ} \mathrm{C}-\mathrm{os}$, sötétben történő nevelés után vizsgálták. A legtöbb embriót a levél inokulumokból 9,08 $\mu \mathrm{M}$ TDZ-t és 2,26 $\mu \mathrm{M}$ 2,4-D-t, míg a levélnyél inokulumokból 4,54 $\mu \mathrm{M}$ TDZ-t és 2,26 $\mu \mathrm{M}$ 2,4-D-t tartalmazó táptalajokról sikerült létrehozniuk. Az embriókból történő regenerációhoz ugyanezeket a táptalajokat használták, de a tenyészeteket immár 16 órás fotóperiódus és 80 $\mu \mathrm{Mm}^{-2} \mathrm{~s}^{-1}$-os megvilágítás mellett nevelték és 2 hónap elteltével értékelték. Explantátumonként átlagosan levélnél 74,4 db, míg levélnyélnél 67,4 db növényt állítottak elö, ami a hajtáskultúrában elérhető 5-15 db-hoz képest jóval több. Áramlásos citometriai vizsgálattal kimutatták, hogy nem volt mixoploid egyed a regeneránsok között.

LAKSHMANAN et al. (2012) szerint S. wallisi leveléből nem lehet regenerálni, de levélnyélből lehetséges. 'Daniel' és 'Domino' fajta levélnyeleiből 3\% szacharózt, TDZ-t vagy 2-iP-t és 2,4-D-t tartalmazó MS táptalajon sikerült regenerációt elérniük. A 2-iP-t és 2,4-D-t tartalmazó táptalajokra inokulált levélnyelek kalluszt nem fejlesztettek, hanem direkt organogenezissel közvetlenül hajtások és gyökerek fejlődtek. A 'Daniel' fajta esetén az $1 \mathrm{mgL}^{-1}$ TDZ és $0,2 \mathrm{mgL}^{-1}$ 2,4-D kombinációja idézte elő a legtöbb embriogén kallusz fejlődését (68\%-a az explantátumoknak reagált), míg a 'Domino' fajtánál a megemelt koncentrációk (2 mgL ${ }^{-1} \mathrm{TDZ}$ és $\left.1 \mathrm{mgL}^{-1} 2,4-\mathrm{D}\right)$ is csak 40\%-ban eredményeztek kompakt, fehér színü, regenerációra hajlamos kalluszt. 
2. táblázat. Összefoglaló táblázat Spathiphyllum fajok és fajták felszaporítása során alkalmazott táptalaj típusokról, növekedésszabályozókról és a felszaporítás eredményéröl szerzőnként feltüntetve

\begin{tabular}{|c|c|c|c|c|c|c|c|c|c|c|c|c|c|}
\hline Szerző & faj(ta) & közeg & táptalaj & szénhidrát & $\mathbf{T}$ & Nappalh. & Fényint. & auxin & citokinin & szaporulat & tömeg & magasság & megjegyzés \\
\hline BiHua, 2000 & 'Xiangshui' & $\mathrm{SZ}$ & MS & $\mathrm{n} / \mathrm{a}$ & $\mathrm{n} / \mathrm{a}$ & $\mathrm{n} / \mathrm{a}$ & $\mathrm{n} / \mathrm{a}$ & $0,1 \mathrm{mg} / \mathrm{l} \mathrm{NES}$ & $2 \mathrm{mg} / \mathrm{l} \mathrm{BA}$ & $\mathrm{n} / \mathrm{a}$ & $\mathrm{n} / \mathrm{a}$ & $\mathrm{n} / \mathrm{a}$ & - \\
\hline Dabski et Kozak, 1997 & 'Svend Neilson' & $S Z$ & $\mathrm{n} / \mathrm{a}$ & $\mathrm{n} / \mathrm{a}$ & $\mathrm{n} / \mathrm{a}$ & $\mathrm{n} / \mathrm{a}$ & $\mathrm{n} / \mathrm{a}$ & $0,1 \mathrm{mg} / \mathrm{l} \mathrm{IES}$ & $10 \mathrm{mg} / \mathrm{l} 2-\mathrm{iP}$ & $\mathrm{n} / \mathrm{a}$ & $\mathrm{n} / \mathrm{a}$ & $\mathrm{n} / \mathrm{a}$ & - \\
\hline Das et al., 2000 & S. wallisii & $S Z$ & MS & $\mathrm{n} / \mathrm{a}$ & $\mathrm{n} / \mathrm{a}$ & $\mathrm{n} / \mathrm{a}$ & $\mathrm{n} / \mathrm{a}$ & - & $1 \mathrm{mg} / \mathrm{l} \mathrm{BA}$ & 7,5/6 hét & $\mathrm{n} / \mathrm{a}$ & $2,5-3 \mathrm{~cm}$ & - \\
\hline \multirow{2}{*}{ Dewir et al., 2006} & \multirow{2}{*}{ S. cannifolium } & SZ & MS & $3 \% \mathrm{SZACH}$. & $25^{\circ} \mathrm{C}$ & $16 \mathrm{~h}$ & $35 \mu \mathrm{Mm}^{-2} \mathrm{~s}^{-1}$ & $4,9 \mu \mathrm{M} I V S$ & $13,32 \mu \mathrm{M} \mathrm{BA}$ & $9,3 / 6$ hét & $\begin{array}{c}1017 \mathrm{mg} \text { ( }=109 \\
\mathrm{mg} / \mathrm{sarj})\end{array}$ & $50 \mathrm{~mm}$ & - \\
\hline & & $F$ & MS & $3 \% \mathrm{SZACH}$. & $25^{\circ} \mathrm{C}$ & $16 \mathrm{~h}$ & $35 \mu \mathrm{Mm}^{-2} \mathrm{~s}^{-1}$ & $4,9 \mu \mathrm{M} I V S$ & $8,88 \mu \mathrm{M} \mathrm{BA}$ & 10,4 / 6 hét & $\begin{array}{c}1876 \mathrm{mg} \text { ( }=180 \\
\mathrm{mg} / \mathrm{sarj})\end{array}$ & $82 \mathrm{~mm} *$ & - \\
\hline Diniz et al., 2008 & S. wallisii & $S Z$ & MS & $\mathrm{n} / \mathrm{a}$ & $26 \pm 2^{\circ} \mathrm{C}$ & $16 \mathrm{~h}$ & $2000 \mathrm{Ix}$ & $0,5 \mathrm{mg} / \mathrm{l} \mathrm{NES}$ & $2 \mathrm{mg} / \mathrm{l} \mathrm{BA}$ & 3,4 / 4 hét & $\mathrm{n} / \mathrm{a}$ & $\mathrm{n} / \mathrm{a}$ & - \\
\hline \begin{tabular}{|l|} 
Fonnesbech et \\
Fonnesbech, 1979 \\
\end{tabular} & 'Clevelandii' & SZ & MS & $3 \%$ SZACH. & $24^{\circ} \mathrm{C}$ & $18 \mathrm{~h}$ & $50 \mu \mathrm{Wcm}^{-2}$ & - & $2 \mathrm{mg} / \mathrm{l} \mathrm{PBA}$ & $\begin{array}{l}5,4 / 4 \text { hét } \\
9,1 / 8 \text { hét }\end{array}$ & $\mathrm{n} / \mathrm{a}$ & $\mathrm{n} / \mathrm{a}$ & - \\
\hline \multirow{3}{*}{ Geneyikli, 2009} & 'Sweet Dario' & SZ & MS & 3\% SZACH. & $25-26^{\circ} \mathrm{C}$ & $\mathrm{n} / \mathrm{a}$ & $3-4000 \mathrm{Ix}$ & - & $1 \mathrm{mg} / \mathrm{l} \mathrm{BA}$ & $15,3 / 8$ hét & $\mathrm{n} / \mathrm{a}$ & $\mathrm{n} / \mathrm{a}$ & - \\
\hline & 'Sweet Chico' & SZ & MS & $3 \% \mathrm{SZACH}$. & $25-26^{\circ} \mathrm{C}$ & $\mathrm{n} / \mathrm{a}$ & $3-40001 x$ & - & $1 \mathrm{mg} / \mathrm{l} \mathrm{BA}$ & $17,8 / 8$ hét & $\mathrm{n} / \mathrm{a}$ & $\mathrm{n} / \mathrm{a}$ & - \\
\hline & 'Sweet Cupido' & SZ & MS & $3 \% \mathrm{SZACH}$. & $25-26^{\circ} \mathrm{C}$ & $\mathrm{n} / \mathrm{a}$ & $3-40001 x$ & - & $1 \mathrm{mg} / \mathrm{l} \mathrm{BA}$ & $18 / 8$ hét & $\mathrm{n} / \mathrm{a}$ & $\mathrm{n} / \mathrm{a}$ & - \\
\hline Han et Yae, 2001 & 'Cupid' & $S Z$ & LS & $\mathrm{n} / \mathrm{a}$ & $\mathrm{n} / \mathrm{a}$ & $\mathrm{n} / \mathrm{a}$ & $\mathrm{n} / \mathrm{a}$ & $\mathrm{n} / \mathrm{a}$ & $2 \mathrm{mg} / \mathrm{l} \mathrm{BA}$ & $\mathrm{n} / \mathrm{a}$ & $\mathrm{n} / \mathrm{a}$ & $\mathrm{n} / \mathrm{a}$ & - \\
\hline Jinshu, 1989 & Spathiphyllum sp. & SZ & MS & $\mathrm{n} / \mathrm{a}$ & $\mathrm{n} / \mathrm{a}$ & $\mathrm{n} / \mathrm{a}$ & $\mathrm{n} / \mathrm{a}$ & $0,1 \mathrm{mg} / \mathrm{I} \mathrm{IES}$ & $1 \mathrm{mg} / \mathrm{l} \mathrm{BA}$ & $\mathrm{n} / \mathrm{a}$ & $\mathrm{n} / \mathrm{a}$ & $\mathrm{n} / \mathrm{a}$ & - \\
\hline Kaçar et al. 2005 & 'Sweet Pablo' & SZ & MS & $3 \%$ SZACH. & $25 \pm 1^{\circ} \mathrm{C}$ & $16 \mathrm{~h}$ & $50 \mu \mathrm{Mm}^{-2} \mathrm{~s}^{-1}$ & - & $1 \mathrm{mg} / \mathrm{l} \mathrm{BA}$ & $8,5 / 4$ hét & $\begin{array}{c}1,17 \mathrm{~g}(=138 \\
\mathrm{mg} / \mathrm{sarj})\end{array}$ & $3,86 \mathrm{~cm}$ & $\begin{array}{c}4 \\
\begin{array}{c}\text { szubkultúra } \\
\text { után }\end{array} \\
\end{array}$ \\
\hline \multirow{2}{*}{$\begin{array}{l}\text { Ramirez-Malagon et al. } \\
2001\end{array}$} & \multirow{2}{*}{ 'Petite' } & \multirow{2}{*}{ SZ } & \multirow{2}{*}{ MS } & \multirow{2}{*}{$n / a$} & \multirow{2}{*}{$25 \pm 2^{\circ} \mathrm{C}$} & \multirow{2}{*}{$16 \mathrm{~h}$} & \multirow{2}{*}{$35 \mu \mathrm{Mm}^{-2} \mathrm{~s}^{-1}$} & $1 \mathrm{mg} / \mathrm{I} \mathrm{IES}$ & $\begin{array}{c}2 \mathrm{mg} / \mathrm{l} \mathrm{BA}+ \\
1 \mathrm{mg} / \mathrm{l} \mathrm{KIN} \\
\end{array}$ & 11,6 / 6 hét & $39 \mathrm{mg} / \mathrm{sarj}$ & $<10 \mathrm{~mm}$ & - \\
\hline & & & & & & & & $0,05 \mathrm{mg} / \mathrm{l} \mathrm{NES}$ & $2 \mathrm{mg} / \mathrm{l} \mathrm{BA}$ & $5,8 / 6$ hét & $116 \mathrm{mg} / \mathrm{sarj}$ & $>20 \mathrm{~mm}$ & - \\
\hline Sahidin, 2011 & S. wallisii & $S Z$ & MS & $n / a$ & $25^{\circ} \mathrm{C}$ & $8 \mathrm{~h}$ & $n / a$ & $\mathrm{n} / \mathrm{a}$ & $1 \mathrm{mg} / \mathrm{l} \mathrm{BA}$ & $3,9 / 50$ nap & $\mathrm{n} / \mathrm{a}$ & $\mathrm{n} / \mathrm{a}$ & - \\
\hline Vardja et Vardja, 2001 & 3 fajta & SZ & MS & $3 \%$ SZACH. & $23 \pm 1^{\circ} \mathrm{C}$ & $n / a$ & $15-60 \mu \mathrm{Mm}^{-2} \mathrm{~s}^{-1}$ & $0,1 \mathrm{mg} / \mathrm{I} \mathrm{IVS}$ & $2 \mathrm{mg} / \mathrm{I} \mathrm{BA}$ & $n / a$ & $\mathrm{n} / \mathrm{a}$ & $n / a$ & - \\
\hline Vargas et Garcia, 1997 & Spathiphyllum sp. & SZ & MS & $3 \% \mathrm{SZACH}$. & $27 \pm 1^{\circ} \mathrm{C}$ & $16 \mathrm{~h}$ & $5000 \mathrm{~lx}$ & $0,5 \mathrm{mg} / \mathrm{l} \mathrm{NES}$ & $2 \mathrm{mg} / \mathrm{l} \mathrm{BA}$ & $10,5 / ?$ & $\mathrm{n} / \mathrm{a}$ & $\mathrm{n} / \mathrm{a}$ & - \\
\hline \multirow{2}{*}{ Watad et al., 1997} & \multirow{2}{*}{ 'Petite' } & $\mathrm{F}$ & MS & 3\% SZACH. & $24 \pm 2^{\circ} \mathrm{C}$ & $16 \mathrm{~h}$ & $60 \mu \mathrm{Mm}^{-2} \mathrm{~s}^{-1}$ & - & 9,3 $\mu \mathrm{M}$ KIN & $14,2 / 25$ nap & $\begin{array}{c}\Delta 539 \mathrm{mg}(=\Delta 38 \\
\mathrm{mg} / \mathrm{sarj})\end{array}$ & $30,7 \mathrm{~mm}$ & - \\
\hline & & SZ & MS & $3 \% \mathrm{SZACH}$. & $24 \pm 2^{\circ} \mathrm{C}$ & $16 \mathrm{~h}$ & $60 \mu \mathrm{Mm}^{-2} \mathrm{~s}^{-1}$ & - & 9,3 $\mu \mathrm{M} \mathrm{KIN}$ & $10,1 / 40$ nap & $\begin{array}{c}\begin{array}{c}\Delta 80 \mathrm{mg}(=\Delta 38 \\
\mathrm{mg} / \mathrm{sarj})\end{array} \\
\end{array}$ & $31,3 \mathrm{~mm}$ & - \\
\hline Wu, 2001 & S. floribundum & SZ & MS & $n / a$ & $\mathrm{n} / \mathrm{a}$ & $\mathrm{n} / \mathrm{a}$ & $\mathrm{n} / \mathrm{a}$ & $\begin{array}{c}0,5-1,5 \mathrm{mg} / \mathrm{l} \\
\mathrm{NES}\end{array}$ & $\begin{array}{c}0,5-2,5 \mathrm{mg} / \mathrm{l} \\
\mathrm{BA}\end{array}$ & 4212 / év & $n / a$ & $\mathrm{n} / \mathrm{a}$ & - \\
\hline
\end{tabular}

Jelmagyarázat:

$\mathrm{T}$ - hömérséklet, 2-iP - 2-izopenteniladenin

* A publikációban $8,2 \mathrm{~mm}$ szerepel, de a mellékelt képek, a szöveg, és a többi adat alapján nagy valószínűséggel hibásan. 


\subsubsection{Gyökereztetés és akklimatizálás}

A gyökereztetés és akklimatizálás sokszor a legproblematikusabb fázis a mikroszaporítási technológia során, ez a szakasz az, aminek a sikeressége számos faj esetében leginkább meghatározza az egész mikroszaporítási folyamat sikerességét (GEORGE et al., 2008).

A Spathiphyllum hibridek mikroszaporítási folyamata során néhány szerző ex vitro gyökereztetést írt le, de többségében az in vitro gyökereztetést preferálják. Ennek oka, hogy a felszaporításhoz leggyakrabban használt citokininből, a BA-böl a növényben keletkező 9- $\beta$-glükopiranozil-benzil-adenin (9G-BA) származék felhalmozódik az alapi részen található kalluszban és/vagy merisztémaszövetekben, ami a gyökérindukciót erősen gátolja. Mivel a 9GBA nagyon lassan bomlik el, - még 9 hét után is kimutatható -, az akklimatizálás alatti gyökeresedésnél problémát jelent (WERBROUCK et al., 1995), a sarjcsokrok aljánál található kisméretü, gyökértelen sarjak akklimatizálásnál könnyen elpusztulnak (MAENE et DEBERGH, 1985). Ennek kiküszöbölésére alkalmazható külön elongációs és gyökeresítő táptalaj használata, bár ez jelentősen növelheti a mikroszaporítási költségeket. MAENE et DEBERGH (1985) javaslata a fenti problémára egy olyan megoldás, amellyel a kultúrák manipulálásával járó munkaigény csökkenthető, de még in vitro körülmények között lehet gyökereztetést végezni. Ök $2 \mathrm{mgL}^{-1}$ IVS tartalmú folyékony táptalaj rárétegezését ajánlják a kimerült táptalajra, megkerülve ezzel a passzálást. Ezzel a módszerrel két hét múlva ki lehet ültetni a sarjakat egyesével szétszedve, és azok könnyen, majdnem 100 \%-osan gyökereznek.

In vitro gyökereztetéssel foglalkozó szerzők közül DABSKI et KOZAK (1997) a legjobb gyökeresedési értékeket a 2 vagy $5 \mathrm{mgL}^{-1}$ IES-val kiegészített táptalajon mérték. VARGAS et GARCIA (1997) a gyökeresítéshez 0,5 $\mathrm{mgL}^{-1}$ IVS-t ill. üres MS táptalajt alkalmaztak. A növényeket sikeresen akklimatizálták. DAS et al. (2000) a gyökeresítéhez megfelelőnek találták a feles töménységű MS táptalajt $2 \mathrm{mgL}^{-1}$ IVS-val és $100 \mathrm{mgL}^{-1}$ aktív szénnel kiegészítve, ahol 15 nap alatt elég gyökér fejlődött az akklimatizáláshoz. A növénykéket steril homok, talaj és szerves anyag 1:1:1 arányú keverékében műanyag tartókban akklimatizálták sikerrel. BIHUA (2000)

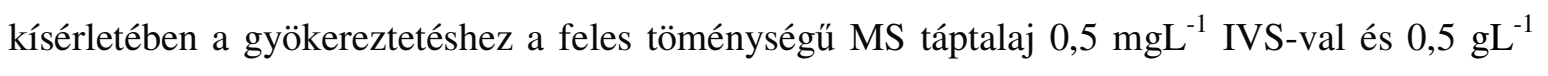
aktív szénnel kiegészítve bizonyult a legjobbnak. Az akklimatizálásnál sikeresen alkalmazta a 3:1 arányú rizspelyvahamu és darált kókuszhéj keverékét közegként. WU (2001) leírásában a gyökeresítéshez a feles koncentrációjú MS táptalaj bizonyult a legjobbnak, $1 \mathrm{mgL}^{-1} \mathrm{NES}$ vagy 1 $\mathrm{mgL}^{-1}$ IVS kiegészítés mellett, ezekben az esetekben a gyökeredés $90 \%$ felettinek bizonyult. Az akklimatizálásra kerülő növénykék több, mint $85 \%$-a életben maradt (összefoglaló 3. táblázat).

DEWIR et al. (2005, 2006) S. cannifolium esetében vizsgálta az akklimatizálás során az akklimatizáló közeg, a tápoldat EC és a megvilágítás hatását a növények növekedésére. A perlit, 
tőzegmoha és vermikulit közül a perlitet találták a legjobb közegnek, a vizsgált fényintenzitások

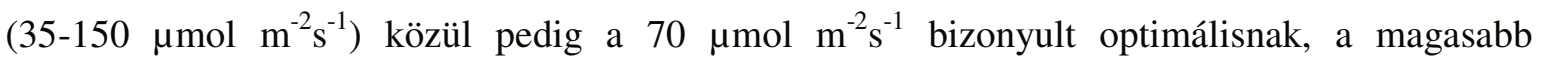
fényintenzitást a növények nem tudták hasznosítani. A tápoldat sókoncentrációjához pedig az 1,2 $\mathrm{dS} \mathrm{m}^{-1}$ értéket találták a legjobbnak.

VAN HUYLENBROECK et DE RIEK (1995) a 'Petite' fajta ex vitro gyökereztetése és akklimatizálása során vizsgálták a cukor és keményítő anyagcseréjét. A lombikból kikerült gyökértelen növényeket tőzegkeverékbe, 104 lukas (22 mm átm.) tálcába ültették, majd $21 \pm 1{ }^{\circ} \mathrm{C}$ on, 80-90\% relatív páratartalom és 16 órás, $100 \mu \mathrm{M} \mathrm{m}^{-2} \mathrm{~s}^{-1}$ fényintenzitás mellett akklimatizálták és rendszeresen vizsgálták. Az akklimatizáció folyamatát két eltérő szakaszra tudták bontani: az első szakaszban, a 10. napig egy adaptációs periódus zajlott, ami alatt a növények nagyon lassú növekedését (mind hajtás, mind gyökér terén) figyelték meg, ezt követően pedig egy gyors gyökér- és hajtásnövekedési periódus következett. A gyökérképződés az 5. nap után indult meg. A klorofill-tartalom az akklimatizálás végére (30 nap) $20 \%$-kal emelkedett, a klorofill a/b arány pedig 1,8-ról 2-re növekedett az első héten. Mindkét megfigyelés arra utal, hogy a fotoszintetikus rendszer hatékonysága javult az akklimatizáció ideje alatt. Az anyagcsere vizsgálatok fényt derítettek arra, hogy a gyökérképződés megindulását a fotoszintetikus asszimiláták felhalmozása előzi meg. VAN HUYLENBROECK et DEBERGH (1996) megállapították, hogy a 3 \%-os szacharóz koncentráció mellett nevelt 'Petite' fajta egyedei már az in vitro tenyésztés végén is pozitív nettó fotoszintetikus rátával jellemezhetők, vagyis autotróf táplálkozásúak, szemben a magasabb szacharóz koncentráció mellett nevelt egyedekkel, ahol csökkent karbonegyensúly, kisebb klorofilltartalom, de nagyobb szárazanyag-tartalom jellemezte a növényeket. Az in vitro táptalaj szacharózkoncentrációja nem volt hatással az akklimatizáció későbbi lefolyására. Az akklimatizáció első hetében az átmeneti stresszt azok a növények tudják jól átvészelni, melyek rendelkeznek felhalmozott tartaléktápanyaggal (szacharóz formájában). Ahogy új levelek és gyökerek kezdenek fejlödni a növényeken, az in vitro környezetben biztosított eltérő szacharózkoncentráció fotoszintetikus rátában okozott különbségei gyorsan kiegyenlítődnek. A szerzők későbbi tanulmányából (VAN HUYLENBROECK et al., 1998) kiderül, hogy a Spathiphyllum azon növények csoportjába tartozik, melyek már in vitro nevelés végén is képesek fotoszintetikusan kompetens leveleket fejleszteni, szemben azokkal a növényekkel, melyek csak raktározó szervként használják a leveleiket in vitro környezetben, pl a Calathea.

VAN HUYLENBROECK et DEBERGH (2000) az akklimatizálás során vizsgáltak szintén a 'Petite' fajtán több élettani paramétert (fotoszintézis, klorofill-a fluoreszcencia, enzimaktivitás, raktározott szénhidrátmennyiség) még in vitro és ex vitro állapotban is. Az autotróf és mixotróf táplálású növények közötti különbségeket az alkalmazott vizsgálati 
módszerek eredményeivel jól meg tudták határozni, csakúgy, mint a növények reakcióját a különböző tenyésztési és klimatikus feltételekre. Általában véve a klorofill-A fluoreszcencia mérését gyors, hasznos és megbízható módszernek találták arra vonatkozólag, hogy képet nyerjenek a növény általános állapotáról. A kapott eredmények jól korreláltak a fotoszintézis mértékével valamint a növényállapot vizuális értékeléséből származó eredményekkel.

WERBROUCK et al. (1995) érdekes megfigyelést tettek az akklimatizálással kapcsolatban a 'Petite' fajtánál, melyen részben albínó levelek fejlödtek, különösen tavaszi akklimatizálás során. A jelenséget a kloroplasztiszok hiánya okozta. A később fejlődő levelek már normálisak voltak, de a jelenség csökkent növekedést és minőségromlást idézett elő.

VAN HUYLENBROECK et al. (1995) megállapította, hogy az akklimatizálás első szakaszában a $300 \mu \mathrm{M} \mathrm{m}^{-2} \mathrm{~s}^{-1}$ fényintenzitás már túl nagy a Spathiphyllum növények számára, és fotoinhibíciót okoz, a $100 \mu \mathrm{M} \mathrm{m}^{-2} \mathrm{~s}^{-1}$ fényintenzitás viszont még nem.

Kísérletek folytak a fotoautotróf in vitro nevelés megvalósítására is Spathiphyllum hibrideknél, bár ezek egyelőre csak a gyökereztetési és preakklimatizálási fázisra korlátozódtak. TANAKA et al. (1992) közöltek először fotoautotróf nevelési kísérletet Spathiphyllum esetében. Saját fejlesztésű, Culture Pack (CP) elnevezésű, jó gázcserét biztosító fluorokarbon polimer filmmel bevont szögletes tenyészedényekben, folyékony táptalajjal átitatott kőzetgyapoton nevelték a növényeket. Az agarral szilárdított, üveg tenyészedényekben nevelkedett egyedekhez képest sokkal vigorózusabb növényeket kaptak, és kísérletet tettek a fotoautotrófia javítására is: a táptalajból elhagyták a szacharózt, a légtér $\mathrm{CO}_{2}$ koncentrációját pedig 3000 ppm-re növelve nevelték a növényeket. Az eredményeik szerint a növények szignifikánsan nagyobbak lettek, mint a nem dúsított légtérben, szénhidrát-kiegészítés mellett növők.

TEIXEIRA DA SILVA et al. (2006) Spathiphyllum 'Merry’ fajtánál próbálták ki egy már jó eredményeket felmutató autotróf tenyésztésre alkalmas edénytípust (a CP továbbfejlesztett változatát, az MP-PFA-t; TANAKA et al. 1996), mely azonban a benne felhasznált anyagok magas ára miatt nem terjedt el a gyakorlatban, valamint egy olcsóbb előállítású tenyészedényt (Vitron), hogy a növényekre kifejtett hatásukat összehasonlíthassák. A 'Merry' fajta in vitro állományát a gyökereztetési fázis előtt helyezték el a tenyészedényekben. Folyékony MS táptalajjal töltötték fel az edények aljára helyezett kőzetgyapot közeget (25 joined-blocks, 5×5, Grodan). Különböző $\mathrm{CO}_{2}$-koncentrációk és fényintenzitások hatását vizsgálva megállapították,

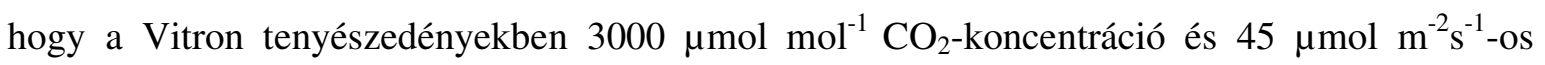
PPFD, $24 \mathrm{~h} \mathrm{~d} \mathrm{~d}^{-1}$ megvilágítás alkalmas a legjobban a 'Merry' fajta gyökeresítésére és akklimatizációjának előkészítésére. A növények a szénhidráttal ellátott táptalajon tenyészőkhöz képest sokkal fejlettebbek lettek. 
LIAO et al. (2006) a 'Sensation' fajtával dolgozva igazolták, hogy a Spathiphyllum hatékony in vitro fotoautotróf neveléséhez szükséges, hogy a tenyészedények lezárása olyan típusú legyen, ami könnyü gázcserét biztosít. Ennek hiányában a növények ugyan életben maradnak a szénhidrátmentes táptalajon is, de fejlődésük csökkentebb mértékü, mint a diffúziót engedő zárással rendelkező tenyészedényben fejlődőeké. Ennek oka méréseik szerint, hogy az impermeábilis tenyészedényekben a $\mathrm{CO}_{2}$ koncentráció a fényperiódusban $80 \mu \mathrm{mol} \mathrm{mol}^{-1}$ értékre is lezuhan, ez pedig a hatékony fotoszintézis fő gátló tényezőjévé válik.

TAN NHUT et al. (2005) vizsgálatukban a fotoautotróf nevelés hatékonyságát próbálták meg javítani a fotoszintetikus fluoreszcens fénycső megvilágítás helyett alkalmazott LED-es fényforrások használatával, sikerrel. Tenyészedényként Culture Pack rendszert használtak, kőzetgyapot közeggel, $3000 \mu \mathrm{mol} \mathrm{mol}{ }^{-1} \mathrm{CO}_{2}$ koncentráció mellett. Eredményeik szerint a $80 \%$ vörös és $20 \%$ kék arányban alkalmazott LED fényforrások spektrális összetétele kedvezöbb a növények fotoszintéziséhez, mint a fotoszintetikus fénycsöveké. A legnagyobb hajtás és gyökér frisstömeg-növekedést $60 \mu \mathrm{mol} \mathrm{m} \mathrm{m}^{-2}$ mellett érték el. Méréseik szerint az így nevelt növények az akklimatizáció ideje alatt is megőrizték a növekedési előnyüket a nem LED-es megvilágítás alatt fejlődő növényekéhez képest.

Az egyes forrásokban szereplő akklimatizálási körülményeket és eredményeket a 3. táblázat foglalja össze. 
3. táblázat. Összefoglaló táblázat Spathiphyllum fajok és fajták gyökeresítése során alkalmazott eljárásokról és táptalaj típusokról, az akklimatizálás körülményeiről és eredményeiröl szerzőnként feltüntetve

\begin{tabular}{|c|c|c|c|c|c|c|c|c|c|c|c|c|}
\hline Szerző & Faj(ta) & Gyökereztetés & Tartam & Méret & Akklimatizáló közeg & Mód & Tartam & Hőm. & Fényintenzitás & Nappalh. & RP & Eredmény \\
\hline Dewir et al., 2006 & S. cannifolium & ex vitro & - & $\begin{array}{c}3-5 \mathrm{~cm}(3-4 \\
\text { levél) }\end{array}$ & perlit & $\begin{array}{c}\text { hidropónika } \\
\text { lyuktálcában } \\
(3,3 \times 5,1 \mathrm{~cm}, 72 \text { lyuk })\end{array}$ & 30 nap & $25 \pm 2^{\circ} \mathrm{C}$ & $100 \mu \mathrm{molm}^{-2} \mathrm{~s}^{-1}$ & $16 \mathrm{~h}$ & $40-50 \%$ & $100 \%$ \\
\hline BiHua 2000 & 'Xiangshui' & $\begin{array}{l}1 / 2 \mathrm{MS} 0,5 \mathrm{mg} / \mathrm{l} \\
\mathrm{IVS}+0,5 \mathrm{~g} / \mathrm{I} \mathrm{AC}\end{array}$ & $\mathrm{n} / \mathrm{a}$ & $n / a$ & \begin{tabular}{|c|}
$\begin{array}{c}\text { rizspelyvahamu és } \\
\text { darált kókuszdióhéj } \\
(3: 1)\end{array}$ \\
\end{tabular} & $\mathrm{n} / \mathrm{a}$ & $\mathrm{n} / \mathrm{a}$ & $\mathrm{n} / \mathrm{a}$ & $\mathrm{n} / \mathrm{a}$ & $\mathrm{n} / \mathrm{a}$ & $\mathrm{n} / \mathrm{a}$ & sikeres \\
\hline Das et al., 2000 & S. wallisii & $\begin{array}{l}1 / 2 \mathrm{MS}+2 \mathrm{mg} / \mathrm{l} \\
\mathrm{IVS}+0,1 \mathrm{~g} / \mathrm{I} \mathrm{AC}\end{array}$ & 15 nap & $n / a$ & $\begin{array}{c}\text { steril homok, talaj, } \\
\text { komposzt (1:1:1) }\end{array}$ & műanyag edények & $\mathrm{n} / \mathrm{a}$ & $\mathrm{n}$ & $\mathrm{n} / \mathrm{a}$ & $\mathrm{n} / \mathrm{a}$ & $\mathrm{n} / \mathrm{a}$ & sikeres \\
\hline Diniz et al., 2008 & S. wallisii & $\mathrm{MS}+1 \mathrm{mg} / \mathrm{I} \mathrm{IVS}$ & 34 nap & - & - & - & - & - & - & - & - & $\begin{array}{c}100 \% \\
\text { gyökerezett }\end{array}$ \\
\hline $\begin{array}{l}\text { Fonnesbech et } \\
\text { Fonnesbech, } 1979 \\
\end{array}$ & 'Clevelandii' & MS PGR nélk. & $n / a$ & $n / a$ & $\mathrm{n} / \mathrm{a}$ & $\mathrm{n} / \mathrm{a}$ & $\mathrm{n} / \mathrm{a}$ & $\mathrm{n} / \mathrm{a}$ & $\mathrm{n} / \mathrm{a}$ & $\mathrm{n} / \mathrm{a}$ & $\mathrm{n} / \mathrm{a}$ & sikeres \\
\hline $\begin{array}{l}\text { Van Huylenbroeck et } \\
\text { Debergh, } 1996\end{array}$ & 'Petite' & ex vitro & - & $\mathrm{n} / \mathrm{a}$ & tőzegkeverék & $\begin{array}{c}\text { 104-es lyuktálcában } \\
\text { (22 mm átm.) }\end{array}$ & 40 nap & $21 \pm 1^{\circ} \mathrm{C}$ & $100 \mu \mathrm{molm}^{-2} \mathrm{~s}^{-1}$ & $16 \mathrm{~h}$ & $80-90 \%$ & sikeres \\
\hline $\begin{array}{l}\text { Ramirez-Malagon et } \\
\text { al. } 2001\end{array}$ & 'Petite' & MS PGR nélk. & 1 hó & $39-116 \mathrm{mg}$ & sterilizált talaj & & 4 hó & \multicolumn{4}{|c|}{ növényházi körülmények } & sikeres \\
\hline Sahidin, 2011 & S. wallisii & in vitro & $\mathrm{n} / \mathrm{a}$ & $n / a$ & $\begin{array}{c}\text { homok, talaj, } \\
\text { szerves anyag } \\
(1: 3: 1)\end{array}$ & műanyag edények & $\mathrm{n} / \mathrm{a}$ & $\mathrm{n} / \mathrm{a}$ & $\mathrm{n} / \mathrm{a}$ & $\mathrm{n} / \mathrm{a}$ & $\mathrm{n} / \mathrm{a}$ & sikeres \\
\hline Vargas et Garcia, 1997 & $\begin{array}{l}\text { Spathiphyllum } \\
\text { sp. }\end{array}$ & $\mathrm{MS}+0,5 \mathrm{mg} / \mathrm{I} \mathrm{IVS}$ & 15 nap & - & - & - & - & - & - & - & - & $\begin{array}{c}\text { sikeres } \\
\text { gyökereztetés } \\
\end{array}$ \\
\hline Watad et al., 1997 & 'Petite' & $\mathrm{MS}+9,3 \mu \mathrm{M} \mathrm{KIN}$ & 25 nap & $\sim 30 \mathrm{~mm}$ & - & - & - & - & - & - & - & $\begin{array}{c}\text { sikeres } \\
\text { gyökereztetés } \\
\text { folyékony } \\
\text { táptalajon }\end{array}$ \\
\hline Wu, 2001 & S. floribundum & $\begin{array}{c}1 / 2 \mathrm{MS}+1 \mathrm{mg} / \mathrm{l} \\
\text { IVS vagy } 1 \mathrm{mg} / \mathrm{l} \\
\text { NES }\end{array}$ & $\mathrm{n} / \mathrm{a}$ & $\mathrm{n} / \mathrm{a}$ & $\mathrm{n} / \mathrm{a}$ & $\mathrm{n} / \mathrm{a}$ & $\mathrm{n} / \mathrm{a}$ & $\mathrm{n} / \mathrm{a}$ & $\mathrm{n} / \mathrm{a}$ & $\mathrm{n} / \mathrm{a}$ & $\mathrm{n} / \mathrm{a}$ & $\begin{array}{l}>90 \% \text { gyök., } \\
85 \% \text { akkl. }\end{array}$ \\
\hline
\end{tabular}

Jelmagyarázat:

AC - aktív szén, IVS - indolvajsav, KIN - kinetin, MS - Murashige-Skoog táptalaj, Nappalh. - nappalhossz, n/a - nincs (nem elérhetö) adat, PGR nélk. - növekedésszabályozó nélkül, RP - relatív páratartalom 


\subsection{A Spathiphyllum hibridek nemesítéséhez felhasznált egyéb in vitro technikák}

\subsubsection{Ginogenezis}

EECKHAUT et al. (2001) dihaploid növények előállításának lehetőségét vizsgálták több fajtán. Ehhez olyan torzsavirágzatokból indítottak steril tenyészetet, melyeknek a buroklevelei még nem voltak kinyílva. Fertőtlenítés után a spadix-ból kimetszették az ováriumokat és különböző táptalajra helyezték őket $23 \pm 2{ }^{\circ} \mathrm{C}$-on, sötétben. 0,25-1 $\mu \mathrm{M}$ TDZ használatát szükségesnek ítélték meg az ováriumkultúra ideje alatt, az imazalil, prokloráz vagy triflumizol használatát pedig előnyösnek tartották, mert hatásukra 6 hét után megduzzadtak az ovulumok és könnyebb volt izolálni őket az ovulumkultúra indításához. Az ovulumkultúra során már nem volt feltétlenül szükséges a citokininek használata, sőt, túl nagy TDZ koncentráció esetén az egyik vizsgált fajtánál diploid parthenogenezist figyeltek meg. A szomatikus sejtek osztódásának visszaszorítása céljából a TDZ helyett ezért zeatint használtak fel a táptalajban az ovulumok neveléséhez. A 4-6 hét múlva keletkezett embrióklasztereket $10 \mu \mathrm{M}$ BA-t és 0,02 $\mu \mathrm{M}$ NES-at tartalmazó táptalajon szaporították tovább, majd 16 órás fotóperiódus mellett, $40 \mu \mathrm{M} \mathrm{m}^{-2} \mathrm{~s}^{-1}$ megvilágítással 6 hónapig hormonmentes táptalajon nevelve azokat akklimatizálásra alkalmas méretü növényeket kaptak. Az egyik fajtánál a felnevelt egyedek között volt néhány dihaploid is, tehát sikerült igazolniuk, hogy lehetséges Spathiphyllum esetén is homozigóta egyedek indukálása ginogenezis révén spontán diploidizációval.

\subsubsection{Protoplaszttenyészet}

Az Araceae családon belül az intergenerikus keresztezések nem kivitelezhetőek, különböző pre- és posztzigotikus inkompatibilitási okok következtében, ami miatt sem a megtermékenyülés, sem az embrió későbbi fejlődése nem lehetséges. A szexuális rekombináció alternatívájaként így a szomatikus fúzió jön szóba, mint lehetséges megoldás. DUQUENNE et al. (2007) ezért a protoplaszttenyészet létrehozásának lehetőségét vizsgálta Anthurium és Spathiphyllum esetében. Különböző koncentrációjú és kombinációjú celluláz és maceráz oldatokkal végezték a sejtfal leemésztését az eltérő forrásból származó sejteken (in vitro levélszövet és szomatikus embriók). A levéleredetü protoplasztok sokkal életképesebbnek bizonyultak, mint a szomatikus embriókból származók, a legjobb enzimkombináció pedig az $1 \%$ celluláz $+0,3 \%$ maceráz volt. A levéleredetű protoplaszttenyészeteket folyékony táptalajon vagy Ca-alginátos beágyazással tudták fenntartani, ahol azok 24-48 óra elteltével elkezdték regenerálni a sejtfalukat. Elektrofúzióval sikeresen fúzionáltak protoplasztokat egymással a két nemzetségből, melyek osztódni is kezdtek, 8 hét elteltével mikrokalluszt képeztek, ami viszont 
nem differenciálódott tovább. Bár a regenerációt nem sikerült megvalósítaniuk, a protoplaszttenyészet kialakítását megoldották.

Későbbi tanulmányukban (EECKHAUT et al., 2009) a 'Daniël' fajtából hoztak létre protoplaszttenyészetet, $100 \mu \mathrm{l}$ agarózcseppekbe helyezték a protoplasztokat és folyékony táptalajon nevelték. 30-50 sejtből álló mikrokolóniák fejlődését figyelték meg, miután glükózt adtak a táptalajhoz, nagy protoplasztkoncentráció mellett. A teljes regenerációt még nem tudták megvalósítani.

\subsubsection{Poliploidizáció}

A poliploidizáció hasznos módszer a növénynemesítésben; lehetővé válnak általa olyan keresztezések, amelyek addig az eltérő ploidszint miatt nem működtek volna, létre lehet hozni a segítségével steril fajtákat, javítani lehet vele a betegségrezisztenciát és -toleranciát (STEBBINS, 1971). A poliploidok általában eltérő morfológiai jelleget mutatnak a diploidokhoz képest, kertészeti szempontból a leginkább figyelemreméltó, hogy sokkal nagyobb és jobb textúrájú virágokkal rendelkezhetnek, a virágzásuk hosszabb lehet. A poliploidizáció általában vastagabb leveleket és szárat, sötétebb zöld színt, megnövekedett szélesség-hossz arányt idéz elő a levelekben, és kompaktabb növekedési habitust is eredményezhet (EECKHAUT et al., 2004). EECKHAUT et al. (2004) célja, hogy triploid Spathiphyllum F1-hibrideket hozzanak létre, melyeket magvetéssel tudnak szaporítani, de nem lehet keresztezésre felhasználni, így védve a nemesítő szellemi termékét. Triploid F1-hibridekhez homozigóta diploid és tetraploid vonalak kellenek. Az előállításukhoz szükséges technológiák közül a ginogenezisen keresztüli homozigóta növények létrehozása már megoldott, de a tetraploid vonalak létrehozása még nem. Ezért Spathiphyllum 'Speedy' fajta WERBROUCK et al. (2000) módszere alapján létrehozott szomatikus embrióin próbálták ki 3 antimitotikus anyag (kolchicin, orizalin és trifluralin) hatását a poliploidok képződésére. A kísérleteik alapján nem célszerü közvetlenül a szomatikus embriókat indukáló táptalajba keverni ezeket az anyagokat, mert gátolják az embriók képződését. A kolchicin bizonyult a legtoxikusabbnak. Így az elsődleges szomatikus embriók továbbnevelését végezték olyan táptalajokon, amelyek tartalmazták a mitózisgátló vegyületeket (10 $\mu \mathrm{M}$ orizalin vagy $10 \mu \mathrm{M}$ trifluralin). A létrejött másodlagos szomatikus embriók között 4,7-5,5\% volt a tetraploidok aránya, melyekből növényt regeneráltak, és akklimatizálták őket. A diploidokkal történő keresztezésük sikeres volt.

Az indukált tetraploid Spathiphyllumok morfológiai jellemzését VANSTECHELMAN et al. (2009) végezték el 5 fajtán, összehasonlítva azokat a diploid növényekkel. A tetraploid Spathiphyllum fajták sejtjei és sejtmagjai nagyobbak voltak, a sztómasürüség kisebb volt, viszont a sztómák méretei nagyobbak lettek. A tetraploidoknál a levél vastagabb volt, és a 
hossz/szélesség aránya kisebb volt a diploidokéhoz képest. A diploid fajtáknak nagyobb volt a levél- és sarjszámuk. A virágzati szár magasságában nem volt különbség, de a tetraploidoknál sokkal kompaktabb, tömzsibb volt a spadix, a spatha pedig sokkal szélesebb lett.

\subsection{Speciális szerveződési formák in vitro környezetben}

\subsubsection{A páfrányok esetén előforduló 'green globular body' (GGB)}

HIGUCHI et al. (1987) Nephrolepis cordifolia mikroszaporítása során, a tenyészeteket a sztólókból indítva figyeltek fel egy különleges szöveti szerveződésre, melyet „green globular bodies"-nak, GGB-nek neveztek el. Ezt a szövetet hasonlónak vélték, mint a Pteris vittata esetében leírt kalluszt (KATO, 1967), de attól eltérő volt, különösen a növekedésszabályozó- és cukorigényeit illetően. Ugyanakkor természetét illetően hasonlónak vélték, mint a Happlopappus gracilis hajtásprimordiumai, melyek zöldes, gömbölyü szövetek, tulajdonképpen hajtásprimordiumok aggregátuma (TANAKA et IKEDA, 1983). Ezek az aggregátumok gyorsan szaporodnak in vitro és könnyen regenerálódnak növénnyé. A $N$. cordifolia-nál megfigyelt GGB-k szöveti elemzése segített feltárni ezen képződmények mibenlétét, és a kalluszszövetektől eltérő mivoltukat. Az első GGB az explantátumként felhasznált sztólócsúcs edénynyalábjának periférikus zónájából tört elö, majd duzzadni kezdett és több GGB formálódott belőle. A megduzzadt GGB-ben több merisztématáj helyezkedik el a belső részen, melyek mindegyike kapcsolódik a központi edénynyaláb rendszerhez. A GGB felülete szinte teljesen pikkelyekkel borított, melyeknek szemölcsös a széle. Szaporodáskor a belső merisztémák osztódása miatt egy-egy a felszínre törve új GGB testet képez (10. ábra).

A GGB-k 1/4 makroelem koncentrációjú MS táptalajon, $30 \mathrm{gL}^{-1}$ szacharóz, és legalább

0,5 $\mathrm{mgL}^{-1}$ BA jelenlétében keletkeztek. Normális sarjak csak 0,5 $\mathrm{mgL}^{-1}$ BA-nél kisebb koncentráció esetén fejlődtek. Az auxinként felhasznált NES koncentrációjának nem volt jelentősége a GGB keletkezés mértékében, de BA nélkül, a NES önmagában is $\left(0,5-1 \mathrm{mgL}^{-1}\right.$ koncentrációban) indukált némi GGB-t, a normális növények mellett. A GGB-k feldarabolással sikeresen szaporíthatók $0,5 \mathrm{mgL}^{-1} \mathrm{BA}$ tartalom mellett, majd hormonmentes táptalajon növényekké regenerálhatók. Egy 3 mm átmérőjü GGB (4 hét alatt keletkezik a sztólócsúcsból) 1 mm-es átmérőjü darabokra vágott részei 4 hét alatt legalább 20-szor osztódnak tovább; így 3 hónap alatt 8000, 6 hónap alatt 160000 növény állítható elő elméletileg egy GGB-ből, ami nagyon hatékony regenerációs rendszert jelent.

HIGUCHI et AMAKI (1989) Asplenium nidus esetén is megfigyelték a GGB-k kialakulását, az in vitro tenyészetet gyöktörzsdarabokról indítva, 2,2 $\mu \mathrm{M}$ BA és 43,7 $\mu \mathrm{M}$ szacharóz mellett MS táptalajon. A szaporodás szempontjából az Asplenium GGB-i eltérőnek bizonyultak a Nephrolepis GGB-itől; itt a GGB külső részén indul meg egy-egy pontban 
határozott sejtosztódási folyamat, új merisztémákat képezve a felületen, melyek aztán GGB testté fejlődnek. A GGB-ket folyékony táptalajon is megpróbálták szaporítani, de a szaporodási ráta az agarral szilárdított táptalajon tapasztalhatóhoz képest kisebb volt. A folyadékkultúrás rendszerek közül a nyugalomban lévő jobb növekedést biztosított, mint az agitált rendszerü. Ezt a külső részen differenciálódó merisztémák mechanikai sérülésével magyarázták.

AMAKI et HIGUCHI (1992) több páfrányfajt vizsgálva megállapította, hogy az egyes fajok GGB-i többé-kevésbé különbözőek lehetnek a szaporodási rátát és a megjelenésüket tekintve, de közös bennük, hogy olyan funkciót töltenek be, mint az orchideák in vitro tenyésztésénél leírt PLB-k (protocorm like bodies): aktívan osztódó sejteket tartalmazó központjaik vannak, melyekből járulékos sarjak fejlődnek. A merisztematikus részek vagy a test belsejében, vagy a felületén helyezkednek el, és folyamatosan új hasonló testeket képeznek megfelelő növekedésszabályozó szerek hatására. E tulajdonságuk miatt a GGB kultúrákat folyamatos, gyorsan osztódó fázisban lehet tartani, de bármikor könnyen tudnak differenciálódni, növényekké regeneráltathatók a táptalajba adagolt bizonyos növekedésszabályozó szerek hatására (LIAO et WU, 2011).

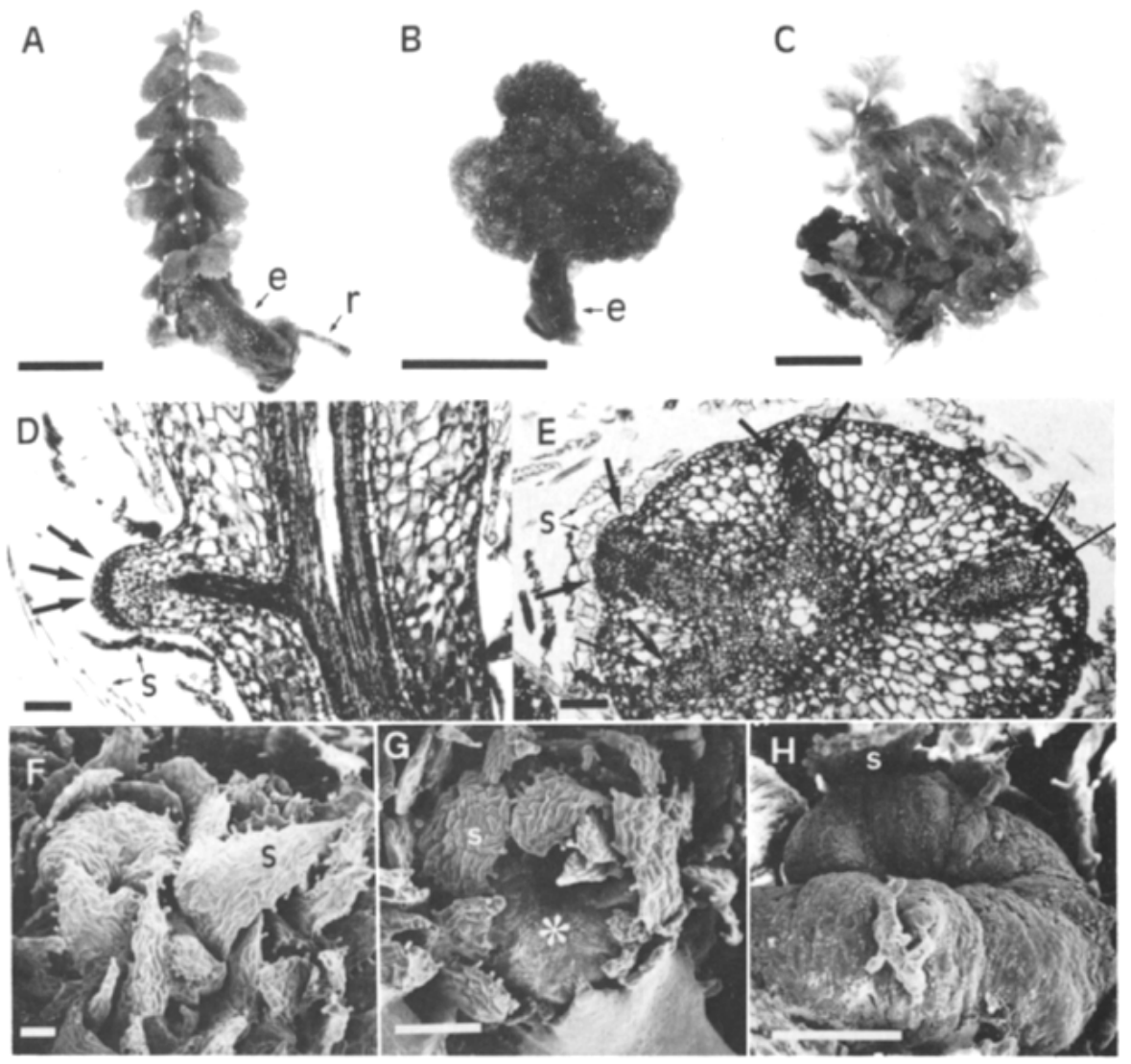

10. ábra. A Nephrolepis cordifolia sztólócsúcsaiből képződött struktúrák. (A) Növényregeneráció a sztólócsúcs explantátumból (e). Gyökér is keletkezett (r). (B) GGB képződés a sztólócsúcsból (e). (C) Növényregeneráció a GGB-ből. (D) Hosszanti metszet a sztólócsúcsból. Nyilak jelzik az alakuló GGB-t. (E) Keresztmetszet a GGB-ről. Nyilak mutatják a merisztematikus szöveteket. (F)-(H) SEM felvételek a GGB-ről. (G) Fejlödő merisztematikus szövet (*). (H) Fejlettebb merisztematikus szövet; S=pikkely. A vonalak az (A)- (C) képeken 5 mm-t, a (D)-(H) képeken $200 \mu \mathrm{m}-\mathrm{t}$ jelölnek (HIGUCHI et al. (1987) nyomán). 
A GGB-n keresztüli regenerációt sok páfrányfaj esetében alkalmazzák sikerrel: Adiantum raddianum, Pteris ensiformis, Rumohra adiantiformis (AMAKI et HIGUCHI, 1992), Blechnum spicant, Pteris ensiformis (FERNÁNDEZ et al., 1996), Polypodium cambricum (BERTRAND et al., 1999), Platycerium bifurcatum (JÁMBOR-BENCZÚR et al., 1994; HUANG, 2004; LIAO et WU, 2011).

A GGB-k indukálása többféle szervből történhet: sztóló (HIGUCHI et al., 1987; PENGWEI, 1997), gyöktörzs (HIGUCHI et AMAKI, 1989; FERNÁNDEZ et al., 1996), levélke, kisebb mértékben levélnyél, gyökércsúcs (BERTRAND et al., 1999). A GGB-k indukciójához és osztódásához a BA szükséges (HIGUCHI et al., 1987; HIGUCHI et AMAKI, 1989; CHENG et al., 2001), de előfordul csak auxin mellett is (PENGWEI, 1997), sőt, olykor hormonmentes táptalajon is (BERTRAND et al., 1999). A BA már kis koncentrációban is akadályozza a GGB-k sarjjá regenerálódását (LIAO et WU, 2011), ehhez általában auxinos (PENGWEI, 1997), vagy hormonmentes táptalaj szükséges (HIGUCHI et al., 1987; FERNÁNDEZ et al. 1996).

\subsubsection{Protokormszerü testek (PLB)}

A PLB mozaikszó a protocorm-like body rövidítéséből származik, MOREL (1960) vezette be a fogalmat a szakirodalomba, mely kifejezetten az orchideákkal kapcsolatban használatos. Cymbidium hajtáscsúcsokon in vitro nevelés közben képződtek kisméretü, lapos hagymácskaszerü képletek, amik hasonlítottak a protokormokra, innen származik a „protokormszerü test” elnevezésük. A protokormok a rendkívül kisméretű embrióval rendelkező és endospermium nélküli orchideamagok csírázása során alakulnak ki (11. ábra), az embrió fejlődésével. Szerepe ezeknek a zöld protokormoknak a megfelelő tartaléktápanyag felhalmozása fotoszintézis révén, hogy a bennük található kétpólusú merisztémából hajtás- és gyökérfejlődés indulhasson meg, amikor már rendelkezésre áll elegendő szénhidrát. A protokormok tulajdonképpen az embriófejlődés egy fázisának tekinthetők (CHAMPAGNAT et MOREL, 1972; NORSTOG 1979; ISHII et al., 1998), ezért egyes szerzők pedig a PLB-ket szomatikus embrióknak tekintik (BEGUM et al., 1994; PARK et al., 2002b). A protokormszerü testek némileg eltérőek lehetnek a magoncok protokormaitól, például nem fotoszintetizálnak. Orchideák hajtáscsúcsait explantátumként megfelelő táptalajra helyezve azok gyakran megállnak a fejlődésben, és hajtáscsúcs helyett embrióként viselkednek: protokormszerü testet hoznak létre. Ezek a PLB-k hajlamosak másodlagos PLB-k képzésére, ugyanúgy, ahogy ez a szomatikus embriók esetében is megfigyelhető (GEORGE et al., 2008).

A protokormokat szétvágva kisebb darabokra, azok újabb protokormokat fejlesztenek, és mindegyikből teljes növény regenerálható. A PLB-k hasonlóan viselkednek, folyamatos osztásukkal sok új PLB-t és rajtuk keresztül sok új növényt lehet nyerni. Mivel a PLB-ket 
vegetatív szövetből, például hajtáscsúcs merisztémájából is lehet indukálni, ezért ez a módszer kifejezetten alkalmas orchideataxonok in vitro fajtaazonos szaporítására (MOREL, 1960). A PLB-k nem csak hajtáscsúcsból, hanem levélszövetből, virágzati részekből, gyöktörzsből, gyökérdarabokból, vékony sejtrétegekből (TCL) keletkezhetnek megfelelő indukciós táptalaj hatására (CHUGH et al., 2009). A legtöbb esetben citokinint, föleg BA-t használnak viszonylag magas koncentrációban a PLB-k indukciójához, de az erős citokininhatással rendelkező TDZ is sokszor szükséges. Az egyes orchideafajoknál PLB indukálásra alkalmazott explantátum típusa, és az indukciót kiváltó táptalaj látható a 4. táblázatban.

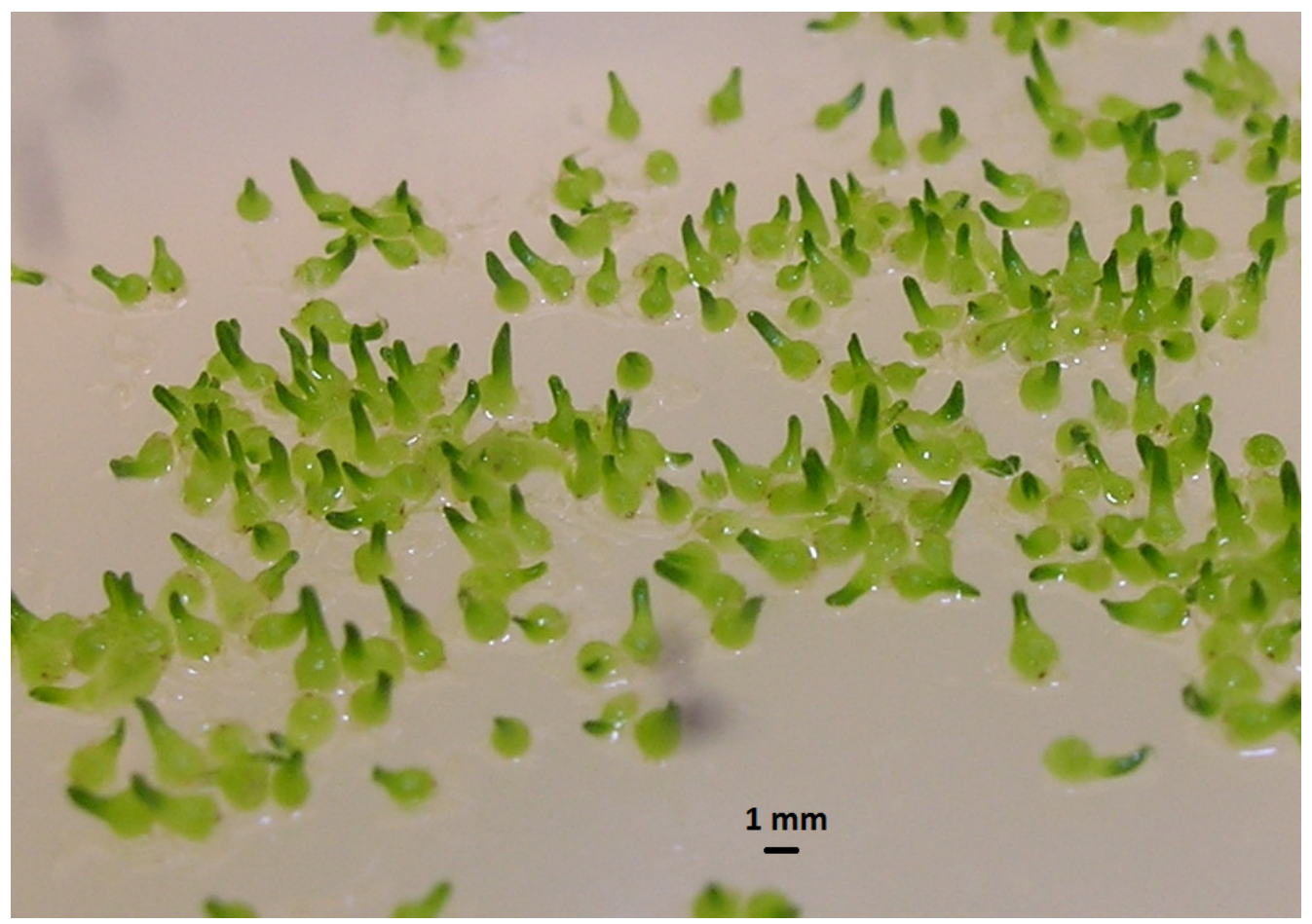

11. ábra. Bletilla striata előrehaladott fejlődési állapotú protokormjai (saját felvétel).

NORSTOG (1979) összehasonlította a klaszterekben fejlődő, árpamagból származó gömbölyü embriókat az orchideák PLB-jeivel; ezek a testek nem tartalmaztak egy egyedüli embrionikus tengelyt, melynek a két végén megtalálható a rügyecskét és gyököcskét fejlesztő merisztematikus rész. Helyette a PLB-kben több merisztematikus központ helyezkedik el, amikből szimmetrikus embriók, vagy hajtás, gyökér fejlődhet.

A PLB kifejezéssel leginkább az orchideák kapcsán lehet találkozni a szakirodalomban, elöfordul mégis néhány forrás, melyek más növények esetén is említik: Heliconia psittacorum a Heliconiaceae / Strelitiziacea családból (GOH et al., 1995); Dichelostemma congestum, Triteleia spp. az Asparagaceae családból (ILAN et al., 1995), Rosa spp. (TIAN et al., 2008) és az Araceae családból is említenek két növényt: a Spathiphyllum-mal közeli rokon Anthurium andraeanum esetében (YU et al., 2009) és a Colocasia esculenta-nál (ABO EL-NIL et ZETTLER, 1976). 
Ezek a szerzők azzal magyarázzák a kifejezés használatát, hogy az általuk vizsgált szerveződés inkább hasonlít a PLB-kre, mint a szomatikus embriókra. YU et al. (2009) Anthurium andreanum esetében levél- és levélnyéldarabokból nyert kalluszon indukált PLB-ket 2,22 $\mu \mathrm{M}$ BA mellett $1 / 2 \mathrm{MS}+30 \mathrm{gL}^{-1}$ szacharózos szilárd táptalajon.

4. táblázat. Jelentősebb orchideafélék PLB indukciójához alkalmas explantátumok és induktív táptalajok (CHUGH et al., 2009 nyomán)

\begin{tabular}{|c|c|c|c|c|}
\hline Orchidea faj & $\begin{array}{l}\text { Explantátum } \\
\text { típusa }\end{array}$ & $\begin{array}{l}\text { Explantátum } \\
\text { eredete }\end{array}$ & Táptalajösszetétel & Szerzők \\
\hline Anacamptis pyramidalis & $\mathrm{HCS}$ & $\mathrm{n} / \mathrm{a}$ & $\begin{array}{c}\mathrm{MS}+\mathrm{NES} / \mathrm{IVS} / \mathrm{IES} \\
0,5-1 \mathrm{mgL}^{-1}+\mathrm{KV}\end{array}$ & Morel, 1970 \\
\hline Cymbidium atropurpureum & $\mathrm{HCS}$ & $n / a$ & $\mathrm{VW}+5 \mathrm{mgL}^{-1} \mathrm{NES}$ & Subramanium et Taha, 2003 \\
\hline Dendrobium wardianum & HCS & in vivo & $\mathrm{MS}+2,5 \mathrm{mgL}^{-1} \mathrm{BA}$ & Sharma et Tandon, 1992 \\
\hline Dendrobium 'Sonja' & $\mathrm{HCS}$ & in vivo & $\begin{array}{c}1 / 2 \mathrm{MS}+1 \mathrm{mgL}^{-1} \mathrm{BA} \\
+7,5 \% \mathrm{KV}\end{array}$ & Sheela et al., 2004 \\
\hline Aerides maculosum & L & in vitro & $\mathrm{MS}+2 \mathrm{mgL}^{-1} \mathrm{BA}$ & Murthy et Pyati, 2001 \\
\hline $\begin{array}{l}\text { Ascocenda 'Fifth State Beauty' } \\
(\text { Ascocenda } \times \text { Vanda) }\end{array}$ & $\mathrm{L}$ & $\begin{array}{l}\text { in vitro és } \\
\text { in vivo }\end{array}$ & $\mathrm{MPR}+1 \mathrm{mgL}^{-1} \mathrm{BA}$ & Vij et Kaur, 1999 \\
\hline Dendrobium hibridek & $\mathrm{L}$ & in vitro & $\mathrm{MS}+44,4 \mu \mathrm{M} \mathrm{BA}$ & Martin et Madassery, 2006 \\
\hline Phalaenopsis hibridek & $\mathrm{L}$ & in vitro & $\begin{array}{c}\mathrm{MS}+88,8 \mu \mathrm{M} \text { BA + } \\
5,4 \mu \mathrm{M} \text { NES }\end{array}$ & Park et al., 2002a \\
\hline Spathoglottis plicata & $\mathrm{L}$ & in vivo & $\begin{array}{c}1 / 2 \mathrm{MS}+0,2 \% \mathrm{AC}+ \\
5,37 \mu \mathrm{M} \mathrm{BA}+0,44 \\
\mu \mathrm{M} N E S\end{array}$ & Teng et al., 1997 \\
\hline Vanda cristata & $\mathrm{L}$ & in vivo & $\begin{array}{c}\mathrm{MPR}+10 \mathrm{mgL}^{-1} \mathrm{BA}+ \\
5 \mathrm{mgL}^{-1} \mathrm{IES} \text { és emelt } \\
\text { konc. }\left(2,2 \mathrm{mgL}^{-1}\right) \\
\mathrm{CuSO}_{4} \cdot 5 \mathrm{H}_{2} \mathrm{O}\end{array}$ & Sharma et Vij, 1997 \\
\hline $\begin{array}{l}\text { Aranda 'Deborah' (Arachis } \\
\text { hookeriana } \times \text { Vanda lamellata) }\end{array}$ & V & in vivo & $\mathrm{KC}+1 \mathrm{mgL}^{-1} \mathrm{BA}+\mathrm{KV}$ & Goh et Wong, 1990 \\
\hline $\begin{array}{l}\text { Ascofinetia (Ascocentrum } \times \\
\text { Neofinetia) }\end{array}$ & V & in vivo & $V W+K V / B U R / B A N$ & Intuwong et Sagawa, 1973 \\
\hline Epidendrum radicans & V & in vivo & $\begin{array}{c}1 / 2 \mathrm{MS}+0,1 \mathrm{mgL}^{-1} \\
\mathrm{TDZ}\end{array}$ & Chen et al., 2002b \\
\hline Oncidium 'Sweet Sugar' & V & in vivo & $\begin{array}{l}1 / 2 \mathrm{MS}^{+} 5 \mathrm{mgL}^{-1} \mathrm{BA} \\
+5 \mathrm{mgL}^{-1} \mathrm{NES}\end{array}$ & Chen et Chang, 2000 \\
\hline Cattleya 'Almakee' & GYD & in vitro & $\begin{array}{c}\mathrm{MPR}+1 \mathrm{mgL}^{-1} \mathrm{KIN}+ \\
1 \mathrm{mgL}^{-1} \mathrm{NES}\end{array}$ & Vij, 1993 \\
\hline Cymbidium 'Kenny Wine Color' & GYD & in vitro & $\begin{array}{c}\mathrm{MS}+1 \mathrm{mgL}^{-1} \mathrm{NES}+ \\
1 \mathrm{mgL}^{-1} \mathrm{BA} \\
\end{array}$ & Yasugi et al., 1994 \\
\hline Doritaenopsis hibrid & GYD & in vitro & $\mathrm{MS}+2,3 \mu \mathrm{M}$ TDZ & Park et al., 2003 \\
\hline Vanda coerulea & GYD & $n / a$ & $\begin{array}{c}1 / 2 \mathrm{MS}+1 \mathrm{mgL}^{-1} \mathrm{NES} \\
+3 \mathrm{mgL}^{-1} \mathrm{TDZ}\end{array}$ & Lang et Hang, 2006 \\
\hline Dendrobium nobile & TLC - HCS-ból & in vivo & $\mathrm{MPR}+4 \mu \mathrm{gL}^{-1} \mathrm{TRIA}$ & Malabadi et al., 2005 \\
\hline Doritaenopsis hibrid & TLC - L-ből & in vitro & $\mathrm{MS}+9 \mu \mathrm{M}$ TDZ & Park et al., 2002b \\
\hline $\begin{array}{l}\text { Phalaenopsis amabilis 'Cool } \\
\text { Breeze' }\end{array}$ & TLC - V-ből & $n / a$ & $\begin{array}{c}\mathrm{MS}+2 \mathrm{mgL}^{-1} \mathrm{BA}+ \\
1 \mathrm{mgL}^{-1} \mathrm{NES}+10 \% \\
(\mathrm{w} / \mathrm{v}) \mathrm{KV}+2 \mathrm{gL}^{-1} \\
\text { pepton }+1 \mathrm{gL}^{-1} \mathrm{AC}\end{array}$ & Sinha et al., 2007 \\
\hline
\end{tabular}

Jelmagyarázat: Explantátum eredete oszlop GYD - gyökérdarab, HCS - hajtáscsúcs, L - levél, TLC - vékony sejtréteg (thin cell layer), V - virágzati rész,; Táptalajösszetétel oszlop AC - aktív szén, BA - benziladenin, BAN - banánkivonat, BUR - burgonyakivonat, IES - indolecetsav, IVS- indolvajsav, KIN - kinetin, KC - Knudson C táptalaj, KV - kókuszvíz , MPR - Mitra-Prasad-Roychowdhury táptalaj, MS - Murashige-Skoog táptalaj, NES - naftilecetsav, TDZ - thidiazuron, TRIA - triakontanol, VW - Vacin-Went táptalaj 


\subsubsection{A Spathiphyllum esetében előforduló képződmények (GGb)}

SZALVA (2003) diplomamunkájában Spathiphyllum 'Queen Amazonica' és 'Petite' fajták steril kultúrába vitelével foglalkozott, a tenyészeteket virágtorzsáról indítva. Ennek során tapasztalta, hogy a sarjak mellett gömbölyű zöldes, telepekben fejlődő szöveti képződmények is keletkeznek, elsősorban a vizsgált legnagyobb citokinin koncentrációk mellett: $2-3 \mathrm{mgL}^{-1} \mathrm{BA}$ vagy 2,5-3 $\mathrm{mgL}^{-1}$ MT és $0,1 \mathrm{mgL}^{-1} \mathrm{NES}$ mellett, $30 \mathrm{gL}^{-1}$ szacharózzal kiegészített 1/2 MS táptalajon. A szövetgömbökből bizonyos idő elteltével sarjregenerációt figyelt meg. Ezért célzottan, gibberellin tartalmú elongációs táptalajokkal is próbálkozott, de egyöntetü regenerációt nem tudott megfigyelni. Az elektronmikroszkópos felvételek alapján (12. ábra) megállapította, hogy rügyszerü képletekről, kevésbé differenciálódott, nagyon rövid szártagú hajtásokról van szó, melyekben a levélprimordiumok egymásra borulva alkotják a szabad szemmel is látható gömbszerü képződményt. A levélprimordiumok felületén sztómákat is talált. JÁMBORNÉ BENCZÚR (2005) a képleteket GGb-nek, azaz 'green globular bud'-nak nevezte el, megkülönböztetve ezáltal őket a páfrányoknál leírt GGB-ktől. OROSZ (2006) szintén diplomamunkája keretében vizsgálta tovább a 'Petite' fajtából létrehozott GGb tenyészeteket. Megállapította, hogy nagyobb $\left(1,5-2,5 \mathrm{mgL}^{-1}\right) \mathrm{BA}$ koncentráció hatására a GGb telepek inkább újabb GGb-ket differenciálnak, míg kisebb BA koncentráció mellett $\left(0,25 \mathrm{mgL}^{-1}\right)$ nagyobb volt a sarjak és gyökerek regenerálódása, de nem egyenletes. NES és $\mathrm{GA}_{3}\left(0,25\right.$ vagy $\left.0,5 \mathrm{mgL}^{-1}\right)$ együttes hatására pedig gátolt volt a növényregeneráció. A sarjregeneráció és az egyes GGb ill. GGb-telep mérete között összefüggést sejtett.

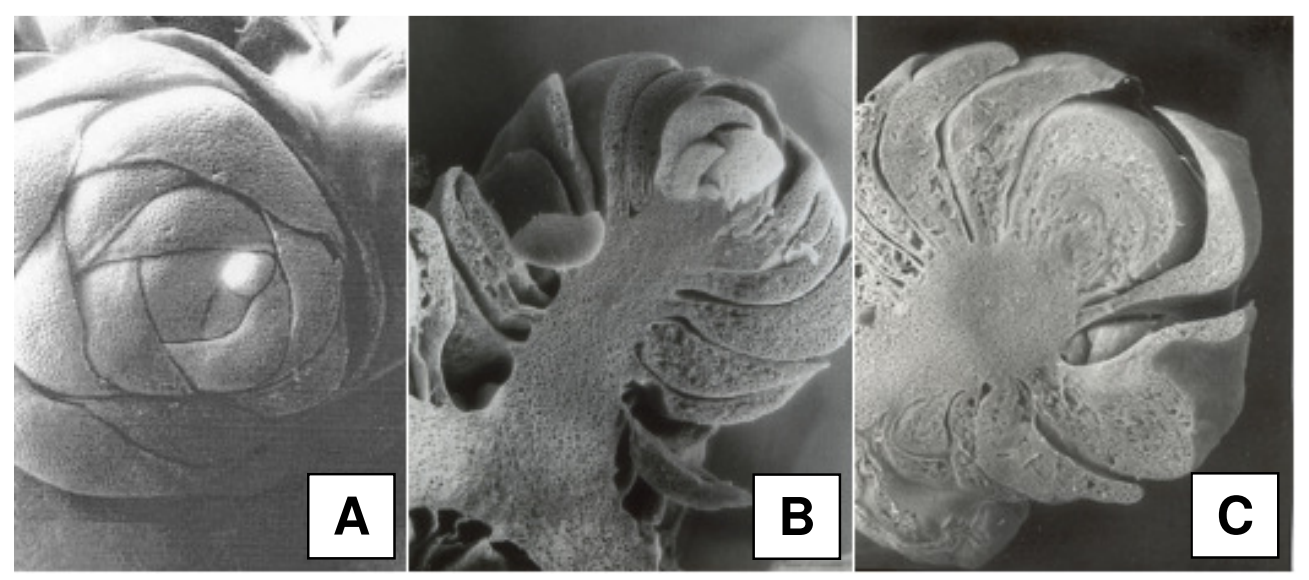

12. ábra. A Spathiphyllum floribundum 'Petite' GGb-iről készült EM felvételek. (A) $2 \mathrm{mgL}^{-1} \mathrm{MT}_{\text {táptalajon }}$ kialakult zárt GGb (SZALVA, 2003). (B) 0,25 $\mathrm{mgL}^{-1}$ BA mellett fejlödött GGb. (C) 1,5 $\mathrm{mgL}^{-1}$ BA mellett fejlődött GGb (OROSZ, 2006).

A Spathiphyllum mikroszaporításáról szóló nemzetközi szakirodalomban ilyen képződmények leírásának egyelöre nincs nyoma. Egyedül WERBROUCK et DEBERGH (1995) említik, hogy 2,5 mgL $\mathrm{m}^{-1} \mathrm{BA}+16 \mathrm{mgL}^{-1}$ imazalil hatására a sarjak tövében nagyon apró, redukálódott merisztématikus csomók jelentek meg, bár a közölt fénykép nem hasonlít GGb-re. 


\subsection{In vitro környezet föbb hatásai a növények élettani jellemzőire}

A mikroszaporítási folyamat sikerességét több tényező befolyásolja, ezek közül talán a legfontosabb az in vitro környezetből kikerülő növények adaptációja a megváltozott fizikai környezethez. A mikroszaporított növények nagy része számára általában sokkot okoz a hirtelen megváltozó környezethez való alkalmazkodás szüksége, mert in vitro körülmények között mind szöveti felépítésüket tekintve, mind élettanilag máshogy funkcionálnak. A mikroszaporítás során az in vitro körülmények kialakításának fö szempontja, hogy a növények minél kevesebb stresszhatásnak legyenek kitéve, és minél kedvezőbb környezeti feltételek álljanak rendelkezésre a lehető legnagyobb szaporodási ráta eléréséhez. Ez többnyire kis fényintenzitást, szénhidrátforrásként egyszerü vagy összetett cukrokkal kiegészített táptalaj melletti heterotróf vagy mixotróf táplálkozást, és nagy relatív páratartalmat takar. Ezek a körülmények jelentősen különböznek az üvegházi és szabadföldi viszonyoktól, és változásokat idéznek elő a növények szervezetében (GEORGE et al., 2008; HAZARIKA, 2006; CHANDRA et al., 2010).

\subsubsection{Szövettani változások}

A legszembetünőbb anatómiai jelleg az in vitro növények kapcsán, hogy jóval gyengébb szöveti szerkezettel rendelkeznek, vékonyabbak a leveleik. A mezofillum gyengén differenciálódott és a vaszkuláris elemek sem fejlettek, nagyok az intercelluláris járatok, a szivacsos parenchima sejtjei nagyok, vakuolizáltak, egyes esetekben sürün helyezkednek el, tömötten (SÁEZ et al., 2012), de ez függ a táptalaj citokinin- és cukortartalmától is (JÁMBORNÉ BENCZÚR, 2005). A paliszád parenchima egy rétegü, és az is inkább gömbölyded sejteket tartalmaz, semmint megnyúltabbakat (GEORGE et al., 2008), vagy olykor teljesen hiányzik is (WETZSTEIN et SOMMER, 1982). DOBRÁNSZKI et al. (2005) kimutatták, hogy a táptalajban alkalmazott citokinin típusa és koncentrációja jelentősen megváltoztathatja az in vitro fejlődött levelek szöveti szerkezetét. A BA növekvő koncentrációja 'Royal Gala' almafajta in vitro leveleinél növekvő vakuolizáltságú epidermiszsejteket és kigömbölyödő parenchimasejteket idézett elő. MT hatására sokkal kompaktabb, tömörebb volt a mezofillum és kiválóan megfigyelhető volt, hogy a koncentrációjának növelésével a mezofillum homogénné vált, a juvenilis levelekre jellemző szöveti szerkezetet öltött. Megállapították továbbá, hogy azok a hormonok, melyek hatására kevésbé differenciált, azaz juvenilis levélszerkezet alakul ki, megnövelik a levelek organogenetikus kapacitását is.

A levél epidermisz szövetében elhelyezkedő sztómák számos in vitro növény esetén nem funkcióképesek: sötétben és szárazságstressz esetén sem csukódnak be a sztóma zárósejtjei (GEORGE et al, 2008.), így a kontrollálatlan vízvesztés miatt a növény elpusztulhat, ha akklimatizáláskor túl alacsony páratartalmú helyre kerül hirtelen. In vitro növényeknél sokszor 
még az exogén adagolt abszcizinsav sem minden esetben vált ki sztómazáródási reakciót (BRAINERD et FUCHIGAMI, 1982; WARDLE et SHORT, 1983), ennek oka az in vitro fejlődött sztómák szerkezeti eltéréseiben keresendő (ZEIGER, 1983). Citrus levelek esetében például az üvegházban nevelt növényeken vese alakúak voltak a zárósejtek, míg az in vitro növényeknél félhold alakúak és lekerekítettek (HAZARIKA et al., 2002). A rendellenes alak a sejtfalba lerakódó anyagok, elsősorban a cellulózból képződő mikroszálak rossz elhelyezkedése miatt alakul ki (PALEVITZ, 1981). A rendellenes sztómamüködés azonban nem minden in vitro növény esetén igaz (SUTTER et LANGHANS, 1982), in vitro környezetben a folyamatosan nagy relatív páratartalom miatt nem kényszerülnek záródásra.

Az akklimatizálás alatt a növények nagymértékü vízvesztesége abból is adódhat, hogy kismértékü vagy teljesen hiányzik az in vitro növények epidermiszéről a kutikula réteg (FUCHIGAMI et al., 1981; WETZSTEIN et SOMMER, 1982), melynek oka szintén a nagy relatív páratartalom a tenyészedényekben. Erre SUTTER et LANGHANS (1982) és WARDLE et al. (1983) világítottak rá, amikor normális kutikulafejlődést értek el káposztaféléken deszikkánsokkal kis páratartalmat létrehozva a tenyészedényekben.

\subsubsection{Változások a fotoszintetikus rendszerben}

A pozitív nettó fotoszintézis két legfőbb korlátozó tényezője in vitro környezetben a megfelelő fényintenzitás hiánya és a tenyészedények $\mathrm{CO}_{2}$-ellátásának mértéke (FUJIWARA et KOZAI, 1995). Az általában alkalmazott fényintenzitás (1200-3000 lux) nem elegendő a megfelelő fotoszintézishez (CHANDRA et al., 2010), ezért a növekedés fenntartásához folyamatos, külsőleg adagolt szénhidrátforrásra van szükség, ami legtöbbször szacharóz, 2-3 \%-os koncentrációban (GEORGE et al., 2008). A szacharóz, vagy egyéb, a növényi anyagcserében hasznosítható cukorvegyület tehát a csökkent mértékü, vagy szünetelő fotoszintézis kompenzálására szolgál. Maga a szacharóz jelenléte is indukál azonban olyan változásokat, amelyek blokkolják vagy csökkentik a fotoszintézis mértékét olyan esetekben is, amikor egyébként a fotoszintézist gátló tényezők nincsenek jelen: a szacharóz hatására kevesebb klorofill képződik, mert gátolja az ALA-szintáz müködését, ami az 5-aminolevulinsavnak, a porfirinvázas molekulák prekurzorának, mint amilyen a klorofill is, a szintéziséért felel (PAMPLIN et CHAPMAN, 1975). VAN HUYSTEE (1977) szerint a hosszabb ideig szacharóz mellett nevelt szövetek már nem nyerik vissza klorofillszintetizáló képességüket. Ezenkívül a fotoszintézisben kulcsszerepet játszó enzim, a ribulóz-1,5-biszfoszfát-karboxiláz (Rubisco) mennyisége is csökkent lehet a levelekben, ha azok fejlődése alatt nagy a szacharóztartalom a növényben (HDIDER et DESJARDINS, 1995). Az ilyen csökkent enzimrendszerrel rendelkező levelekben az akklimatizálás során sem normalizálódik a müködés, és gyakorta elpusztulnak. 
Csak az újonnan fejlődő levelek mutatnak normális fotoszintetikus enzimaktivitást (GROUT et MILLAM, 1985). Egyes növények viszont, mint amilyen a Dieffenbachia is, pozitív karbonegyensúllyal jellemezhetők in vitro környezetben szacharóz jelenléte mellett is (GEORGE et al., 1993), és akklimatizáláskor könnyedén átállnak teljesen autotróf táplálkozásra (GROUT, 1988). VAN HUYLENBROUCK et DEBERGH (1996) csak az in vitro nevelés végén (és később az akklimatizálás során) mérte Spathiphyllum 'Petite' növényeken a nettó fotoszintetikus rátát, ami kezdeti 3\%-os szacharóz koncentráció mellett pozitív értéket mutatott. Ezek szerint a Spathiphyllum is lehet olyan növény, mely pozitív karbonegyensúllyal rendelkezik in vitro nevelés során, az exogén szénhidrát jelenléte mellett, de az is lehet, hogy a mérés idejére (6 hét kultúrálás után) elfogyott a táptalajból a cukor, és a növény autotróf módon kezdett táplálkozni. HAZARIKA (2006) olyan eseteket is említ, amikor a cukor jelenléte a táptalajban pozitívan befolyásolta egyes növények klorofilltartalmát, fotoszintetikus kapacitását, és ennek kapcsán hivatkozik KOCH (1996) megállapítására, aki szerint azon megfigyelések, hogy a cukorellátás pozitív hatással van a fotoszintézisre, más esetekben pedig a cukor jelenléte a fotoszintézis mértékének leszabályozását indukálja, nincsenek összhangban egymással. Szerinte a fotoszintézis mértékének csökkenése elsősorban azért áll be, mert zavar keletkezik a szénhidrátforrás és -felhasználás egyensúlyában, a növény nem tudja mire felhasználni a többlet szénhidrátot. Megfelelő fejlődés esetén azonban (amit a külsőleg adagolt cukor biztosíthat) áttolódhat az egyensúly egy idő után a felhasználásról a termelésre, vagyis a fotoszintézis rátája megnő a táptalajban lévő cukor ellenére is (KOVTUN et DAIE, 1995).

\subsection{Speciális tenyésztési rendszerek}

\subsubsection{Fotoautotróf mikroszaporítás}

A fotoszintézist limitáló fizikai tényezők, a fényintenzitás és a megfelelő $\mathrm{CO}_{2}$ ellátás biztosítása esetén a fotoszintetikus apparátussal már rendelkező fotomixotróf táplálkozású növények teljesen fotoautotróf módon is nevelhetők in vitro, külsőleg adagolt szénhidrátforrások nélkül (KUBOTA, 2001). FUJIWARA et al. (1987) kimutatta, hogy a hagyományos tenyészedényekben tipikus diurnális ciklusa van a $\mathrm{CO}_{2}$-koncentráció változásának: a fényszakasz megkezdése után nem sokkal hirtelen lecsökken a $\mathrm{CO}_{2}$ parciális koncentrációja a tenyészedény légterében a növényekben meginduló fotoszintézis miatt, majd a kompenzációs szint alá csökkent $\mathrm{CO}_{2}$-koncentráció limitálja a Rubisco karboxiláz funkcióját (ISHIBASHI et al., 1997), vagyis nem képes biztosítani a fotoszintézis megfelelő müködését, limitáló tényezővé válik (NAVARRO et al., 1994). Ez arra utal, hogy az in vitro nevelt növények jó része megörzi fotoszintetikus aktivitását, de a fotoszintézist gátló fizikai tényezők miatt fotomixotróf módon kényszerülnek táplálkozni. A megfelelő $\mathrm{CO}_{2}$ ellátást a tenyészedények lezárási módjának 
megváltoztatásával, a jobb gázcsere lehetőségének biztosításával lehet elérni, és a hatékonyságot tovább lehet növelni, ha a nevelöhelyiség légterében megnöveljük a $\mathrm{CO}_{2}$ parciális nyomását (XIAO et al., 2011). A fotoautotróf mikroszaporításnak számos előnye van:

- a megnövekedett fotoszintetikus ráta jobb növekedést biztosít

- az akklimatizáció könnyebb, kisebb a veszteség

- a hiperhidratáció kialakulásának nincsenek meg a feltételei (kevésbé nagy RP)

- kevesebb a fertőzésből eredő veszteség

- nagyobb méretü tenyészedények használatára van lehetőség

- nagyobb az automatizálási lehetőségek száma

Emellett természetesen jelentkeznek hátrányok is:

- komplex technikát és tudást igényel a környezet kontrollja

- megnövekedett világítási, hütési és $\mathrm{CO}_{2}$ dúsítási költségek

- a felszaporítási szakaszra még nem optimalizálták a technológiát

Jelenleg a fotoautotróf nevelésnek az elongációs és gyökeresítési fázisban van nagy jelentősége, ahol jó minőségü, vigorózus növényeket tudnak vele előállítani (KUBOTA, 2001).

Spathiphyllum taxonok esetén is sikerrel alkalmaztak már fotoautotróf nevelési rendszert in vitro, ahogy azt a 3.2.3 alfejezet végén ismertettem.

\subsubsection{Bioreaktoros tenyésztési rendszerek}

A mikroszaporítás rendkívül hatékony módja a növények szaporításának, de egyben költséges eljárás is. Egy mikroszaporított növény árának 60-65\%-át Európában a bér és a rárakódó terhek teszik ki (TÓTH, 2005). A költséghatékonyság növeléséhez tehát a legkézenfekvőbb az automatizált rendszerek fejlesztése, ami minimalizálja a humán munkaigényt. A bioreaktor rendszerek folyékony tápoldatot használva lehetőséget adnak erre. Az első így kivitelezett mikroszaporítási technológiát 1981-ben közölték Begonia szaporításához (TAKAYAMA et MISAWA, 1981). Azóta a bioreaktorokban mind a szomatikus embriogenezisre, mind az organogenezisre alapuló fejlődési úton keresztül sikerrel szaporítottak már növényeket, felhasználva szomatikus embriókat, hagymákat, mikrogumókat, hajtásokat (PAEK et al., 2001), bár egyelőre a kereskedelmi termelés még főként a szilárd táptalajon, organogenetikus úton megvalósított regenerációt használja (ZIV, 2005). A szomatikus embriók, protokormszerü testek, merisztématikus klaszterek sokkal inkább alkalmasak a folyékony táptalajon, agitálva történő tenyésztéshez méretükből és többé-kevésbé gömbölyü formájukból kifolyólag, míg a differenciáltabb szerveződési formák (pl. hajtások) esetében a folyékony táptalaj rendellenes fejlődést okozhat, gyakori a hiperhidratáció kialakulása (ZIV, 2010). Ennek megelőzésére a rendszerek levegőztetését növelni, a növényi részek táptalajba merülésének 
mértékét pedig csökkenteni próbálják, például periodikus elárasztásos rendszerrel (TEISSON et al., 1996). A periodikus elárasztásos rendszert kombinálva úszó membránlapokkal és távtartó hálóval valósították meg Spathiphyllum esetében is a hajtásokkal történő folyékony táptalajos bioreaktoros tenyésztést (WATAD et al., 1997; DEWIR et al., 2006). Azon fajok esetében, ahol ugyan nem figyelték meg szilárd táptalajon merisztematikus klaszterek, törpe hajtáscsomók kialakulását, lehetőség van ezek indukálására. Sokszor már maga a folyékony közegbe merítés, folyamatos forgatás és mozgatás elegendő ezek indukciójához, de növekedési retardánsok használata is elterjedt (ZIV, 2005). Paklobutrazollal és ancimidollal indukálták a merisztematikus csomók kialakulását Hemerocallis esetében (CHEN et al., 2005; ADELBERG et al., 2005). Burgonyánál és banánnál az ancimidol és kinetin megfelelő arányával érték el, hogy a hajtások rügyklaszterekké, gladiólusznál pedig merisztematikus klaszterekké redukálódjanak (ZIV et al., 1998). Bár HIGUCHI et AMAKI (1989) alkalmatlannak találta a vizsgált páfrányfajok GGB-it folyadékkultúrás tenyésztésre, ZIV et al. (1998) Nephrolepis-nél működő módszert ír le. Az orchideák PLB-i is alkalmasak folyadékkultúrás-bioreaktoros tenyésztésre: Oncidium esetén YANG et al. (2010) ír le müködő rendszert, Phalaenopsis-nál YOUNG et al. (2000), Doritaenopsis-nál LIU et al., (2001). A PLB-k, hasonlóan a merisztématikus- vagy rügyklaszterekhez a levelek hiányában nem fogékonyak a hiperhidratációra. A PLB vagy egyéb kisméretü képletek bioreaktoros felszaporítása után sokszor egy szilárd táptalajon történő második fázist is alkalmaznak a hajtásmegnyúlás, gyökeresedés elérésére; sarjak, hagymák esetében erre nincs szükség, azok közvetlenül akklimatizálhatók.

\section{7 Újfajta növekedésszabályozó szerek}

A növekedésszabályozó anyagok közül „klasszikus”-nak tekinthetők azon vegyületek, melyeket növények széles körénél használnak fel in vitro vagy akár in vivo is. Ezek többsége szintetikus anyag, melyek jól imitálják a növényekben természetesen előforduló hasonló biológiai hatású komponenseket. A mesterséges auxinok közül ide sorolható az indolilvajsav (IVS), a naftilecetsav (NES) és a 2,4-diklórfenoxiecetsav (2,4-D), míg a citokininek közül a kinetin (KIN), benziladenin (BA), benziladenin-ribozid (BR), valamint a természetes előfordulású 2-izopenteniladenin (2-iP) és zeatin (Z). A gibberellineknek nincs szintetikus ekvivalensük, növekedésszabályozási célra a növényekben is előforduló 3-gibberellinsavat $\left(\mathrm{GA}_{3}\right)$ használják főként (GEORGE et al., 1993). Ezekkel szemben egyes citokininféleségeknek és a gibberellinantagonista anyagoknak a felhasználása szükebb körben történik, speciális szerep jut nekik. Jónéhányat az elmúlt évtizedekben fedeztek fel és kezdték alkalmazni, ezért újfajta növekedésszabályozóként is lehet kategorizálni ezeket. 


\subsubsection{Topolinok}

Miután kimutatták, hogy a BA növényben képződő származéka felhalmozódhat az in vitro növényekben, gátolhatja a gyökeresedést (WERBROUCK et al., 1995) és akár fitotoxicitást is okozhat (BOGAERT et al., 2006), ezért az egyébként könnyen hozzáférhető, olcsó, és emiatt széleskörben alkalmazott szintetikus citokinin helyett alternatívákat kerestek. Az O-glükoziláció a citokininek természetes anyagcseréjének fontos lépése, ha rossz pozícióban történik a citokinin jellegü molekulán, akkor a lebomlás nem úgy megy végbe, ahogy a természetes citokininek esetében. A BA-nel kapcsolatban az a probléma, hogy a növényi anyagcsere során a $\mathrm{BA} \mathrm{N}^{7}$ vagy $\mathrm{N}^{9}$ pozícióban történő glükozilációja esetén biológiailag inaktív, de kémiailag nagyon stabil vegyület jön létre. Ennek az elhúzódó bomlása miatt, ha kis mértékében is, de folyamatosan szabadul fel aktív citokininforma. Ezért a szóba jövő BA alternatívák azok a BA változatok, amelyeken az $\mathrm{N}^{9}$ pozíció már foglalt (például ribozidcsoporttal a $\mathrm{BR}$ esetén, vagy tetrahidropiranilcsoporttal a PBA-ban), vagy a hidroxilált BA-analógok (WERBROUCK et al., 1996; SUBBARAJ, 2011). Az első hidroxilált BA vegyületet Populus levélből mutatták ki (HORGAN et al., 1975), később találtak több változatot is, és a topolinok elnevezést adták a csoportnak (STRNAD et al., 1997), majd más növényekben, pl. Zantedeschia aethiopica (Araceae család) termésében is találtak topolinokat (DAS NEVES et PAIS, 1980). WERBROUCK et al. (1995) végül a meta-topolint (MT) javasolták a BA alternatívájának. Összehasonlítva a BA-nel in vitro a növényekre kifejtett hatásukat, megállapították, hogy sokkal kevésbé gátolja a gyökeresedést. A sarjadzásra gyakorolt hatásában azonban volt különbség az MT és BA között, bár a nagyobb méretű sarjak számát nem változtatta jelentősen, a BA esetében jóval több, kisméretü sarj is kialakult a növényen. További problémák is elöfordultak a BA-nel kapcsolatban: egy levélvariegált Petunia fajta mikroszaporítása során a metoxi-metatopolinribozid a BA-hez képest sokkal kevesebb albínót és zöld sarjat eredményezett, vagyis jobban megőrizte a levelekben a szövetszerkezeti stabilitást, ami kimérák mikroszaporítása esetén nagyon lényeges (BOGAERT et al., 2006). AMOO et al. (2011) arra a következtetésre jutott, hogy Barleria greenii mikroszaporítása során a topolinok használata kisebb arányban okozott abnormális adventív sarjakat, mint a BA használata. Több szerző is leírta, hogy MT használatával sikerült a hiperhidratációt visszaszorítani: Malus × domestica 'Royal Gala' (DOBRÁNSZKI et al., 2002), valamint Aloe polyphylla esetében (BAIRU et al., 2007). Bár a BA-t még mindig nagyon elterjedten használják a mikroszaporítás során, egyre több új és pozitív eredmény jelenik meg a szakirodalomban a meta-topolinnal kapcsolatban, ahol más citokininekkel szemben jobb hatást lehet vele elérni (5. táblázat). 
5. táblázat. Néhány olyan in vitro kultúra, ahol a MT vagy származéka jobb hatású volt, mint a többi vizsgált citokinin (AREMU et al., 2012 nyomán)

\begin{tabular}{|c|c|c|c|c|c|}
\hline Faj & $\begin{array}{l}\text { Kipróbált } \\
\text { citokininek }\end{array}$ & $\begin{array}{l}\text { Preferált } \\
\text { citokinin }\end{array}$ & $\begin{array}{c}\text { Optimális } \\
\text { koncentráció }\end{array}$ & $\begin{array}{c}\text { Vizsgált } \\
\text { paraméter }\end{array}$ & Szerzők \\
\hline Aloe ferox & $\mathrm{BA}, \mathrm{MT}, \mathrm{MTR}$ & MT, MTR & $5 \mu \mathrm{M}$ & sarjadzás & Bairu et al., 2009 \\
\hline Aloe polyphylla & $\begin{array}{c}\text { BA, MT, MTR, } \\
\text { MEMT, } \\
\text { MEMTR, Z } \\
\end{array}$ & MT, MTR & $5 \mu \mathrm{M}$ & $\begin{array}{l}\text { sarjadzás, } \\
\text { gyökeresedés, } \\
\text { hiperhidratáció }\end{array}$ & Bairu et al., 2007 \\
\hline Barleria greenii & $\begin{array}{l}\text { BA, KIN, MT, } \\
\text { MTR, MEMTR }\end{array}$ & MEMTR & $7 \mu \mathrm{M}$ & $\begin{array}{l}\text { sarjadzás, sarjak } \\
\text { abnormalitása }\end{array}$ & Amoo et al., 2011 \\
\hline Beta vulgaris & $\mathrm{BA}, \mathrm{MT}, \mathrm{OT}, \mathrm{Z}$ & MT, MTR & $\mathrm{n} / \mathrm{a}$ & $\begin{array}{l}\text { sarjadzás, } \\
\text { gyökeresedés }\end{array}$ & $\begin{array}{l}\text { Kubalákova et Strnad, } \\
1992\end{array}$ \\
\hline Hypericum hibrid & $\mathrm{BA}, \mathrm{MT}$ & MT & $5 \mu \mathrm{M}$ & sarjminőség & Meyer et al., 2009 \\
\hline $\begin{array}{l}\text { Malus } \times \text { domestica } \\
\text { 'Royal Gala' }\end{array}$ & $\begin{array}{c}\mathrm{BA}, \mathrm{KIN}, \mathrm{MT} \\
\mathrm{BA}+\mathrm{KIN}, \mathrm{BA}+\mathrm{MT}\end{array}$ & MT & $2,1 \mu \mathrm{M}$ & sarjadzás & Dobránszki et al., 2005 \\
\hline $\begin{array}{l}\text { Malus } \times \text { domestica } \\
\text { 'Jonagold' }\end{array}$ & BA, BAR, MT & MT & $20,7 \mu \mathrm{M}$ & sarjadzás & $\begin{array}{l}\text { Magyar-Tábori et al., } \\
2002\end{array}$ \\
\hline Musa spp. & $\begin{array}{l}\text { BA, MT, MTR, } \\
\text { MEMT, } \\
\text { MEMTR, Z }\end{array}$ & MT, MTR & $22,2 \mu \mathrm{M}$ & $\begin{array}{l}\text { sarjadzás, } \\
\text { növényminőség, } \\
\text { sarj } \\
\text { abnormalitás }\end{array}$ & Bairu et al., 2008 \\
\hline Musa spp. 'CEMSA 3/4' & BA, MT, TDZ & MT & $4,4 \mu \mathrm{M}$ & sarjadzás & Roels et al., 2005 \\
\hline $\begin{array}{l}\text { Pelargonium } \times \text { hortorum } \\
\text { 'Bergpalais' }\end{array}$ & $\mathrm{BA}, \mathrm{MT}$ & MT & $4,1 \mu \mathrm{M}$ & $\begin{array}{l}\text { sarjadzás és } \\
\text { minőség }\end{array}$ & $\begin{array}{l}\text { Wojtania et } \\
\text { Gabryszewska, } 2001\end{array}$ \\
\hline Petunia $\times$ hybrida & BA, MEMTR & MEMTR & $2 \mu \mathrm{M}$ & kimérastabilitás & Bogaert et al., 2006 \\
\hline Pinus sylvestris & $\mathrm{BA}, \mathrm{MT}, \mathrm{TDZ}, \mathrm{Z}$ & MT & $25 \mu \mathrm{M}$ & sarjadzás & De Diego et al., 2010 \\
\hline $\begin{array}{l}\text { Spathiphyllum } \\
\text { floribundum 'Petite' }\end{array}$ & $\begin{array}{c}\text { BA, BAR, PBA, } \\
\text { MT }\end{array}$ & MT & $10 \mu \mathrm{M}$ & $\begin{array}{l}\text { gyökeresedés, } \\
\text { akklimatizáció }\end{array}$ & Werbrouck et al., 1996 \\
\hline
\end{tabular}

Jelmagyarázat:

BA - benziladenin, KIN - kinetin, MEMT - metoxi-metatopolin, MEMTR - metoxi-metatopolin-ribozid, MT - metatopolin, MTR - metatopolin-ribozid, OT - ortotopolin, PBA - tetrahidropiranil-benziladenin, TDZ - thidiazuron, $\mathrm{Z}$ - zeatin

Található azonban az irodalomban olyan példa is, amikor a MT vagy származékai nem bizonyultak jobbnak: Vaccinium sp. esetében (MEINERS et al., 2007) és azáleáknál (MERTENS et al., 1996) a TDZ jobb hatású volt, mint a MT. Agave fajoknál a BA és a TDZ nagyobb szaporulatot biztosít (ROSALES et al., 2008), Pinus pinea-nál a TDZ (CORTIZO et al., 2009), Sorbus torminalis-nál a BA (MALÁ et al., 2009).

\subsubsection{Fenilurea-típusú citokininek}

A citokinineket kémiai szerkezetük alapján két fö csoportra lehet bontani: a természetesen is előforduló adenin-származékokra és a fenilurea alapú csoportra (SUBBARAJ, 2011). Ebbe az utóbbi csoportba tartozik a 2-klór-4-fenilurea (CPPU) és a thidiazuron. Az 1,3difenilurea természetesen is előfordul, kókuszvízből mutatták ki (GEORGE et al., 2008). A legismertebb és legelterjedtebben használt fenilurea-típusú citokinin a thidiazuron. Szerkezetéből 
adódóan nem igazi citokinin vegyület, de nagyon erős citokinin hatással rendelkezik, mert hatékonyan képes gátolni a növényekben a citokininek katabolizmusában központi szerepet játszó citokinin-oxidázt (HUETTEMAN et PREECE, 1993; HARE et VAN STADEN, 1994). Intenzív hatását annak is köszönheti, hogy viszonylag stabil vegyületnek mutatkozik a biológiai rendszerekben, akár 48 órán keresztül is megmarad eredeti formájában (MOK et MOK, 1985). Fás növények mikroszaporítása során az egyik leghatékonyabbnak bizonyuló, regenerációt kiváltó anyagnak tekinthetjük. A TDZ kisebb koncentrációban kiváltotta az organogenezist fás növényeknél, melyek egyébként csak nagy koncentrációban alkalmazott aromás citokininek esetén voltak hajlandóak regenerálódásra, illetve olyan növényeknél, melyek egyáltalán nem reagáltak ezekre a citokininekre (MURTHY et al, 1998). A TDZ nem csak a citokinineket képes imitálni, hanem az auxinokat is, és egyedüli növekedésszabályozóként képes a szomatikus embriogenezis indukálására (ami egyébként föleg az auxinokhoz kötött) sok faj esetén (VISSER et al., 1992; SAXENA et al., 1992; GILL et SAXENA, 1993). Az auxin-metabolizmus módosításában is szerepet játszhat tehát, amit megerősít, hogy az auxin-inhibitorokkal gátolni lehet a TDZ által kiváltott szomatikus embrióindukciót (HUTCHINSON et al., 1996). In vivo alkalmazását írja le HENNY (1995), aki Spathiphyllum 'Petite' fajta esetén TDZ beöntözésével nagyszámú sarjat indukált cserepes növényeken. Érdekes tulajdonsága a TDZ-nak, hogy az endogén citokinin-bioszintézis folyamatába is beleszól: képes volt Phaseolus lunatus kallusztenyészetét megindítani, így a kalluszt TDZ kezelés után citokininmentes táptalajra helyezve az tovább nőtt folyamatosan, ellenben a TDZ kezelésben nem részesült kallusszal, aminek a növekedése megállt citokinin hiányában (CAPELLE et al., 1983). LU (1993) összefoglaló munkájából kiderül, hogy a különböző szerzők által általában alkalmazott TDZ koncentráció járulékos hajtásindukcióra $0,0022-0,088 \mathrm{mgL}^{-1}(0,01 \mu \mathrm{M}-0,4 \mu \mathrm{M})$ közötti, tehát meglehetősen kicsi a többi citokinin szokásos koncentrációjához képest.

\subsubsection{Triazolok és imidazolok}

A gombás fertőzések kontrollálása céljából vizsgáltak egyes fungicid hatású vegyületeket növényi táptalajban történő alkalmazhatóságra, amikor felfigyeltek arra, hogy néhány vegyületcsoport hatással van a táptalajon nevelt növények fejlődésére is (SHIELDS et al., 1984). Az imidazol-típusú fungicidek közül elöször az imazalillal kapcsolatban figyelték meg, hogy szinergista módon erősítette a citokininként alkalmazott BA hatását Spathiphyllum 'Petite' tenyészetében (WERBROUCK et DEBERGH, 1995). A későbbi vizsgálatok során kiderült, hogy Anthurium in vitro tenyészetében is kimutatható ez a hatás, és az imazalillal rokon egyéb imidazol-vegyületek is rendelkeznek vele: prokloráz, triflumizol, valamint a triazolok csoportjába tartozó paklobutrazolnál is megfigyelhető. A hatás kifejezetten az Araceae családba 
tartozó növényeknél jelentős, és a citokininek széles körénél megfigyelhető; benzil-adenin mellett zeatin, meta-topolin, thidiazuron esetén is (WERBROUCK et DEBERGH, 1996). Az imidazol fungicidek szerkezetileg közös jellemzője a triazolokkal és a pirimidin-karbinolokkal egy heterociklusos gyürü, ami tartalmaz egy sp2 hibridizált nitrogént, szabad elektronpárral (13. ábra).

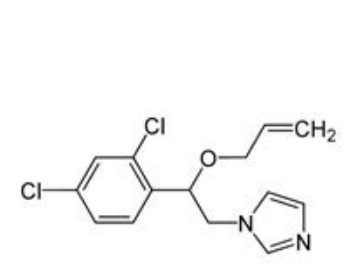

Imazalil<smiles>CC(C)(C)C(O)C(Cc1ccc(Cl)cc1)n1cncn1</smiles>

Paklobutrazol

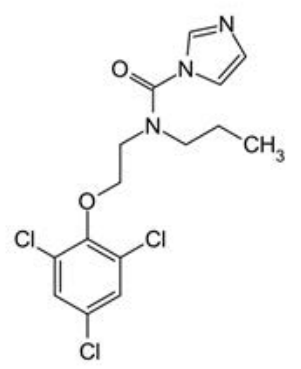

Prokloráz<smiles>COc1ccc(C(O)(c2cncnc2)C2CC2)cc1</smiles>

Ancimidol

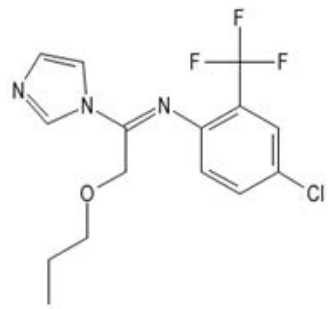

Triflumizol

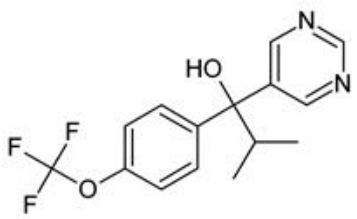

Flurprimidol

13. ábra. Az imidazol-típusú (felső sor) és triazol-típusú (alsó sor) fungicidek, melyek növényi növekedésszabályozóként is hatnak.

Az ilyen tulajdonsággal rendelkező molekulák gátolni tudják gombákban az ergoszterolbioszintézist, növényekben pedig a gibberellin-bioszintézist. Ezek a vegyületek gátolják a terpenoid bioszintézisútban szerepet játszó citokróm P450-függő monooxigenázok (metilhidroxilázok) müködését is, melyek azonban nem csak a gibberellinek, hanem az abszcizinsav, a citokininek és a szterolok bioszintézisében is szerepet játszanak (RADEMACHER, 1991; GROSSMAN, 1992). Az imidazoloknál nem tapasztalható kifejezett növekedésgátló hatás, szemben a triazolokkal (WERBROUCK et DEBERGH, 1996).

\subsubsection{Paklobutrazol}

A paklobutrazol királis molekulaszerkezete következtében a szintézise során kétféle enantiomer keletkezik: 2S,3S- és 2R,3R-paklobutrazol. A kétféle enantiomer közül a fungicid tulajdonságért elsősorban a 2R,3R-paklobutrazol felelős, ami a szterol-bioszintézist gátolja, míg a növekedési retardáló hatásért kizárólag a 2S,3S-paklobutrazol komponens a felelős, ami szelektíven gátolja a gibberellinsavak bioszintéziséhez vezető anyagcsereutat (LENTON et al, 
1994). A paklobutrazol tartalmú növekedésszabályozó készítmények egyaránt tartalmazzák mindkét enantiomert, emiatt mind a fungicid, mind a növekedési retardáló hatással rendelkeznek.

A PBZ erős növekedésgátló hatást fejt ki növények széles körénél, fiziológiai változásokat indukál, beleértve a gibberellin- és szterolbioszintézis csökkentését, hatására nő a klorofill-koncentráció (ABDUL JALEEL et al, 2007; BAÑÓN et al., 2002), megnő az abiotikus stressz-tolerancia (LIN et al., 2006; BANINASAB, 2009; MANIVANNAN et al., 2008), és késlelteti az öregedést, ami a megnövekedett endogén citokinintartalom következménye (FLETCHER et al., 2010). Dugványoknál a gyökeresedést elősegítő hatása erősen fajfüggőnek mutatkozott: Solenostemon scutellarioides, Plectranthus australis, Prunus laurocerasus, Salix discolor, Vitis labrusca, Phaseolus vulgaris fajoknál elősegítette azt, míg Ficus benjamina, Ficus pumila, Hibiscus rosa-sinensis, Zebrina pendula esetén nem volt pozitív hatása, ám a hajtásnövekedést teljesen leállította. A fotoszintetikus aktivitás megnövekedését is leírták a PBZlal történő kezelés hatására talajon keresztüli beöntözés, levélre permetezés és in vitro táptalajba juttatás esetén is (BEROVA et ZLATEV, 2000; ZHENG et al, 2012). A hajtásnövekedésre kifejtett gátló hatása miatt azonban a megnövekedett mennyiségü fotoszintetikus asszimiláták elsősorban raktározószervekbe kerülnek (ZHENG et al, 2012; TEKALIGN et HAMMES, 2004). A PBZ meggyorsítja a termésképződést és -érést (BEROVA et ZLATEV, 2000). A PBZ széleskörü szabadföldi felhasználása mellett in vitro körülmények között, táptalajok alkotójaként is felhasználható: más triazol típusú gibberellinbioszintézis-gátlókkal egyetemben sikerrel használták folyékony táptalajokban a hajtásmegnyúlás gátlására és a hiperhidratáció kialakulásának megakadályozására (CHEN et al, 2005; ADELBERG et al, 2005), az akklimatizálás megkönnyítésére (MURALI et DUNCAN, 1995; CHA-UM et al, 2009), szomatikus embriogenezis kiváltására (CHEN et CHANG, 2000), mikrogumó előállításra (STEINITZ et LILIEN-KIPNIS, 1989; PELACHO et al., 1994), valamint in vitro gyökeresítésre (RICHIE et al, 1991; WEN et al, 2013). Fontos és terjedőben lévő alkalmazása az ancimidollal együtt, hogy hatásukra merisztematikus csomók, klaszterek formájában, redukálva jelennek meg az újonnan keletkező adventív részek a növényen, és ebben a formában alkalmasak folyékony táptalajon, bioreaktor rendszerben történő tenyésztésre (CHEN et al., 2005; ADELBERG et al., 2005). A hiperhidratációt is sikeresen vissza lehet szorítani az alkalmazásával (ADELBERG et al., 2005).

\subsubsection{Ancimidol és flurprimidol}

A flurprimidol az ancimidolhoz hasonló kémiai szerkezetü vegyület, hatásmechanizmusa hasonló, ezért annak alternatívájaként alkalmazható vegyület. 2-4x annyira aktív, mint az ancimidol és sokkal stabilabb a táptalajban. A flurprimidol a Cutless márkanevü készítmény hatóanyaga (THEODORIDIS, 2006), amelyet pázsitfü növekedésretardáló kezelésére 
használnak, elkerülve ezzel a gyakori nyírás szükségességét (GAUSSOIN et al., 1997). A paklobutrazollal ellentétben a flurprimidol levélen keresztül is felszívódik (a PBZ csak gyökéren keresztül), ezért gyümölcsfák kezelése esetén már az azévi hajtásokon is kifejti a törpítő hatását, míg a PBZ csak a kezelést követő évben. A talajba kerülve gyorsabban bomlik, mint a PBZ: felezési ideje 6 hónap, míg a PBZ-nak 18 (EBRAHEM, 1985). BURKHART et MEYER (1991) a Pinus strobus esetén alkalmazták az ancimidolt és a flurprimidolt, hogy oldalhajtásokat gyökereztessenek. $5 \mu \mathrm{M}$ koncentrációban alkalmazták mindkét szert kombinálva 0,5 $\mu \mathrm{M}$ NESval. A hajtások jobban gyökeresedtek a triazolok hatására, mint az önmagukban alkalmazott auxinoktól. Az ancimidol hatását jobbnak találták. Fitotoxicitást egyiknél sem tapasztaltak. KOZAK (2002) Gloriosa rotschildiana in vitro gumóképződését vizsgálta triazolokkal, melyek közül a flurprimidollal érte el a legjobb eredményt: $0,2 \mathrm{mgL}^{-1}$ koncentrációnál volt a legnagyobb a képződő gumók tömege, míg $1 \mathrm{mgL}^{-1}$-es koncentráció serkentette a gumók kihajtását. 


\section{Anyag és módszer}

\subsection{Steril kultúra indítási kísérletek}

\subsubsection{Indítás intenzív virágzásban lévő spadixból}

Az első kultúraindítási kísérlet (2008. október) során a Spathiphyllum floribundum 'Petite' fajta még nem elzöldült virágtorzsájából próbáltam steril tenyészetet létesíteni. A buroklevelüktől megfosztott spadixokat a következő fertőtlenítési eljárásnak vetettem alá:

- 1 órás folyóvizes mosás

- 95 perc áztatás antibiotikum-oldatban $\left(250 \mathrm{mgL}^{-1}\right.$ Vancomycin $+100 \mathrm{mgL}^{-1}$ Cephotaxim, gyártó mindkét vegyszernél: Duchefa Biochemie B.V., Hollandia)

- 1 perc mosás 70 v/v\%-os etanolban (DV és $96 \%$-os etanol (Reanal Finomvegyszergyár Zrt., Magyarország) felhasználásával készítve)

- 12 perc áztatás háztartási Hypo 33\%-os oldatában (Chemität Kft, Magyarország)

A steril desztillált vizes öblítést követően az explantátumokat az alábbi táptalajokra helyeztem (6. táblázat):

6. táblázat. Az intenzív virágzásban lévő spadixokkal végzett indítási kísérlet táptalajai

\begin{tabular}{|c|c|c|c|c|c|c|}
\hline $\begin{array}{l}\text { táptalaj } \\
\text { neve }\end{array}$ & $\begin{array}{l}\text { BA- } \\
\text { tartalom } \\
\left(\mathrm{mgL}^{-1}\right)\end{array}$ & $\begin{array}{l}\text { egyéb } \\
\text { citokinin } \\
\left(\mathrm{mgL}^{-1}\right)\end{array}$ & $\begin{array}{l}\text { auxin } \\
\left(\mathrm{mgL}^{-1}\right)\end{array}$ & $\begin{array}{l}\text { gibberellin } \\
\left(\mathrm{mgL}^{-1}\right)\end{array}$ & $\begin{array}{l}\text { szénhidrát } \\
\left(\mathrm{gL}^{-1}\right)\end{array}$ & alap \\
\hline „B” & 5 & - & \multirow{4}{*}{$0,2 \mathrm{IVS}$} & \multirow{4}{*}{$0,5 \mathrm{GA}_{3}$} & \multirow{4}{*}{$30 \mathrm{SZACH}}$. & \multirow{4}{*}{$1 \times \mathrm{MS}$} \\
\hline „BP1” & 5 & $5(2-i P)$ & & & & \\
\hline ,BK” & 2,5 & $2,5(\mathrm{KIN})$ & & & & \\
\hline „BP2” & 5 & $10(2-\mathrm{iP})$ & & & & \\
\hline
\end{tabular}

Jelmagyarázat: BA - benziladenin, $\mathrm{GA}_{3}$ - gibberellinsav, IVS - indolvajsav, KIN - kinetin, MS Murashige-Skoog táptalaj, SZACH. - szacharóz

\subsubsection{Indítás hajtásrügyekből}

A második indítási kísérlet (2008. november) során az első indításból megmaradt anyanövények gyökérnyak feletti hajtásrügyeit használtam fel. Azok kipreparálása előtt 2 nappal Fundazol 50 WP (hatóanyag: benomil) 0,1\%-os oldatával beöntözést végeztem a cserepes növényeken. A kipreparálást követően pedig az alábbi fertőtlenítési eljárást alkalmaztam: 
- 1 órás folyó csapvizes mosás, 20 percenként $1 \mathrm{ml}$ Tween 80 (Reanal Finomvegyszergyár Zrt., Magyarország) adagolása a vízsugárba

- 16 órás áztatás antibiotikum-oldatban $\left(2 \mathrm{mgL}^{-1}\right.$ malachitzöld (Reanal Finomvegyszergyár Zrt., Magyarország), $250 \mathrm{mgL}^{-1}$ Vancomycin, $100 \mathrm{mgL}^{-1}$ Cephotaxim)

- 1 perc mosás $70 \mathrm{v} / \mathrm{v} \%$-os etanolban

- 10 perc áztatás Clorox (Clorox Europe Ltd. Egyesült Királyság) 33\%-os oldatában 0,1\% Tween 80-nal kiegészítve

- öblítés steril desztillált vízzel háromszor

A fertőtlenítési eljárás végeztével az explantátumokat az első indítási kísérletben ismertetett táptalajokra helyeztem.

\subsubsection{A virágzat érettségének hatása a tenyészet indítási fázisában}

A harmadik indítási kísérletben (2012. október) a 'Petite' fajtától morfológiai bélyegek alapján eltérő, de nem azonosított fajtával dolgoztam, explantátumként a különböző állapotú spadix-okat használtam fel:

- zárt buroklevelü, ki nem nyílt virágzat (,1-es”)

- nyílt buroklevelü, fehér, ki nem nyílt virágzat (,2-es”)

- zöld, elnyílt virágzat (,,3-as” típusú explantátum) (14. ábra).

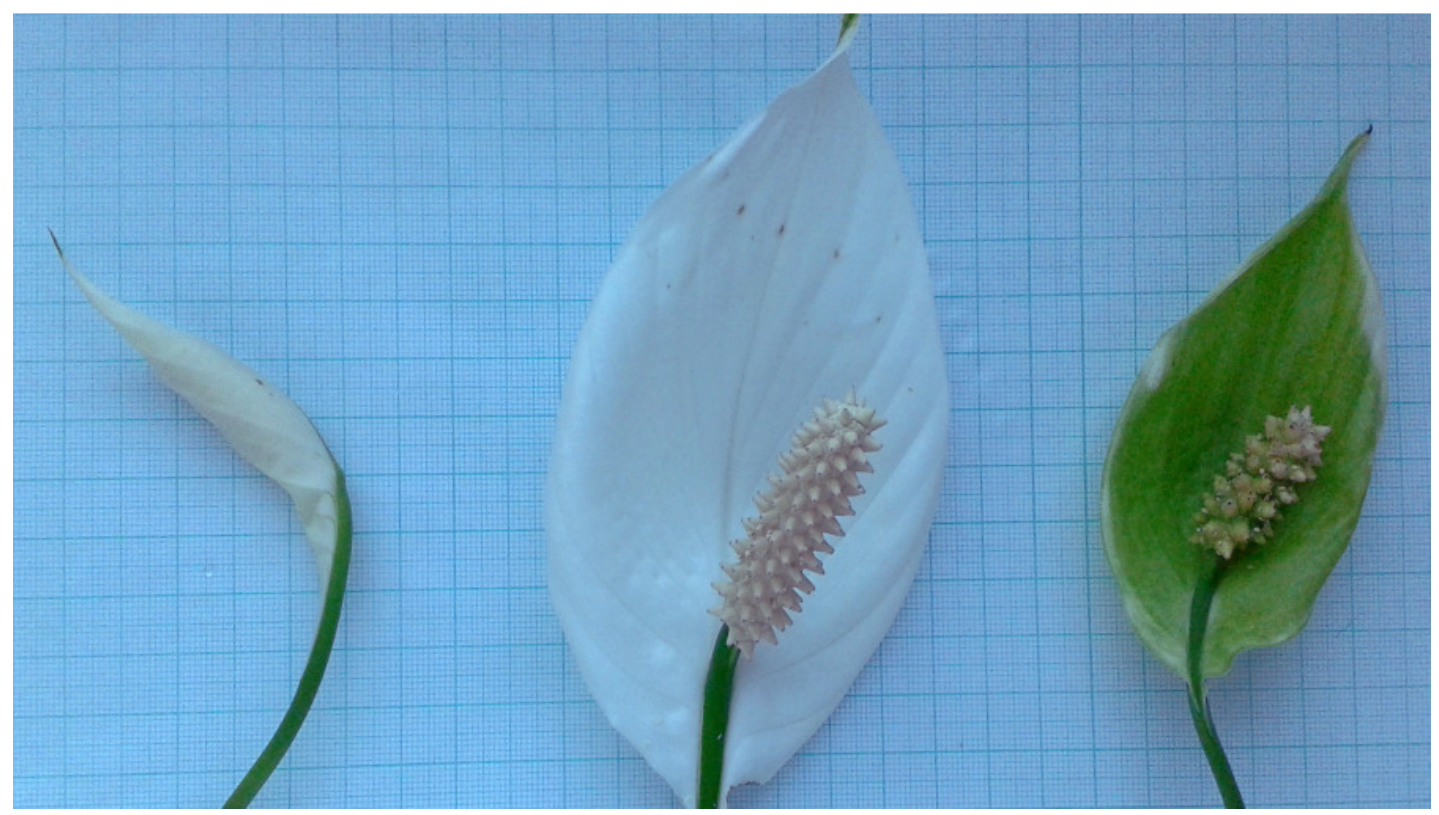

14. ábra. A különböző fenológiai stádiumban lévő torzsavirágzatok, mint explantátumok a steril kultúra indításához nem azonosított Spathiphyllum fajtánál (balról jobbra: 1-es, 2-es és 3-as típusú explantátum). 
A buroklevéllel zárt virágzat sterilizálási folyamata az alábbi volt:

- 30 perc mosás 33\%-os Clorox oldatban 0,1\% Tween 80-nal kiegészítve

- 10 perc áztatás 0,3\%-os $\mathrm{HgCl}_{2}$-oldatban (Reanal Finomvegyszergyár Zrt., Magyarország)

- lelángolás steril boxban 96\%-os etanolba mártás után

A kinyílt buroklevelü fehér és zöld virágzatok esetében pedig:

- 1 órás folyó csapvizes mosás néhány csepp mosogatószerrel

- 24 órás áztatás antibiotikum oldatban $\left(1 \mathrm{gL}^{-1}\right.$ neomicin-szulfát, $25 \mathrm{mgL}^{-1}$ Nystatin (Duchefa Biochemie B.V., Hollandia) dimetilszulfoxidban oldva, $3 \mathrm{mgL}^{-1}$ malachitzöld)

- 40 perc áztatás 50\%-os Clorox-oldatban

- 30 perc áztatás $0,3 \%$-os $\mathrm{HgCl}_{2}$-oldatban

- öblítés steril desztillált vízzel

A torzsákat hosszában vágtam ketté, a nagyobbakat még keresztben is. Így $97 \mathrm{db}$ explantátumot kaptam összesen, melyeket 87 lombikban helyeztem el, először inokuláló táptalajra, amely nem tartalmazott a makro- és mikroelemeken, vitaminokon és szacharózon kívül semmilyen növekedésszabályozót, majd egy hét elteltével kerültek a növekedésszabályozó anyagokat is tartalmazó indítótáptalajra, melynek összetételét a 7. táblázat mutatja.

7. táblázat. A harmadik indítás során alkalmazott indító táptalajok összetétele

\begin{tabular}{|c|c|c|c|c|}
\hline $\begin{array}{l}\text { Táptalaj } \\
\text { elnevezés }\end{array}$ & alap & szénhidrát & citokinin & auxin \\
\hline „M1” & \multirow{4}{*}{$1 / 2 \times M S$} & \multirow{3}{*}{$30 \mathrm{gL}^{-1}$ szacharóz } & $1 \mathrm{mgL}^{-1} \mathrm{MT}$ & \multirow{4}{*}{$0,1 \mathrm{mgL}^{-1} \mathrm{NES}$} \\
\hline ,M2” & & & $2 \mathrm{mgL}^{-1} \mathrm{MT}$ & \\
\hline „M3” & & & $3 \mathrm{mgL}^{-1} \mathrm{MT}$ & \\
\hline „B1” & & $20 \mathrm{gL}^{-1}$ szacharóz & $1 \mathrm{mgL}^{-1} \mathrm{BA}$ & \\
\hline
\end{tabular}

Jelmagyarázat: BA - benziladenin, 1/2 ×MS - fél makroelem koncentrációjú Murashige-Skoog táptalaj, MT - metatopolin, NES - naftilecetsav

$\mathrm{Az}$ inokulumok 3 hónap elteltével kerültek friss táptalajra, mindegyik ugyanolyan összetételüre, mint amilyenen volt. Az értékelésre a következő 3 hónap elteltével került sor.

\subsubsection{Indítás akklimatizált növények virágzatából}

A negyedik (2013. április) és ötödik (2013. június) kultúraindítás során saját in vitro tenyészetből származó és akklimatizált 'Petite' fajtát indítottam virágtorzsákról, valamint a negyedik indításnál még egy Spathiphyllum floribundum fajtát is bevontam a kísérletbe. Fehér, 
még nem virágzó, de már kinyílt buroklevelü virágzatokat szedtem le az anyanövényekről, és ezeket sterilizáltam. A fertőtlenítési eljárásból az antibiotikum-kezeléseket elhagytam, a higany(II)-kloridos mosást viszont nem:

- 15 perc folyó csapvizes mosás 5 percenként $1 \mathrm{ml}$ Tween 80 adagolása a vízsugárba

- 20 perces áztatás 50\%-os Clorox-oldatban 0,1\% Tween 80-nal kiegészítve

- 20 perc $0,3 \%$-os $\mathrm{HgCl}_{2}$-oldatos mosás

A Clorox-os és higany(II)-kloridos mosás hatékonyságát mágneses keverővel növeltem. A fertőtlenítés után háromszor öblítettem steril desztillált vízzel az inokulumokat, melyeket a virágtorzsa hosszanti tengelyére merőlegesen vágtam keresztbe, kétfelé. Az explantátumokat a metszlappal lefelé helyeztem az indító táptalajra, ami 1/2× makroelem koncentrációjú MS alaptáptalaj volt kiegészítve $30 \mathrm{gL}^{-1}$ szacharózzal, $3 \mathrm{mgL}^{-1}$ MT-nal, 0,1 mgL $\mathrm{mLS}^{-1} \mathrm{NES}$-val.

\subsection{A Spathiphyllum GGb telepekkel folytatott kísérletek}

\subsubsection{Eltérő NES-koncentrációk vizsgálata}

A GGb forma regenerációjának vizsgálatához a NES-at kis koncentrációban alkalmazva $\left(0 ; 0,5 ; 0,75 ; 1 ; 1,25 ; 1,5 \mathrm{mgL}^{-1}\right)$ kombináltam $0,25 \mathrm{mgL}^{-1}$ BA-nel. Az alaptáptalaj $1 / 2 \times \mathrm{MS}$ volt, kiegészítve $20 \mathrm{gL}^{-1}$ szacharózzal. A GGb telepeket kisebb, 3-5 rügyet tartalmazó részekre vágtam, és kezelésenként 42-45 darab telepet helyeztem táptalajra, tenyészedényenként 3 db-ot. A kísérlet 6 hónapig tartott a telepek lassú növekedése miatt, 2008 decembere és 2009 júniusa között. Ez idő alatt a tenyészeteket egyszer, 3 hónap elteltével passzáltam friss táptalajra, egyben hagyva és ugyanúgy elhelyezve azokat, ahogy álltak. Ekkor történt az első időközi értékelés is, melynek során a tenyészetek fejlődési állapotát határoztam meg bonitálással. A második értékelés 5 hónappal indítás után történt és szintén az állapot vizsgálatára terjedt ki. A harmadik és lezáró értékelés során megmértem a fejlődött telepek átmérőjét, osztályoztam állapotukat, megszámoltam a telepben található GGb-k darabszámát, és megmértem átmérőjüket. Azoknál a telepeknél, ahol regeneráció indult meg, megmértem a sarjak és gyökerek hosszát, megszámoltam a mennyiségüket.

\subsubsection{Különböző citokininek alkalmazása folyékony tápközegben}

A GGb forma folyadékkultúrás tenyésztésre való alkalmasságának vizsgálatához a GGb tenyészeteket agarral nem szilárdított tápközegben is elhelyezve vizsgáltam azok reakcióját. Agitált rendszert használtam, tehát a tápközeg és így a GGb telepek is folyamatosan mozgásban voltak. Ehhez a GGb telepeket $100 \mathrm{~cm}^{3}$-es, $20 \mathrm{~cm}$ hosszú, $3 \mathrm{~cm}$ átméröjü üvegcsövekben helyeztem el, a mozgatásukról egy rotátor (típusjelölés nélkül, gyártotta Óbuda TSZ) 
gondoskodott, $20 \mathrm{rpm}$ sebességgel. A rotátor síkja $30^{\circ}$-os szögben dől a függőlegestől, és erre a síkra merőlegesen lehet behelyezni az üvegcsöveket a tartóba. Mivel az előzetes kísérletek alapján pozitív eredményeket kaptam, vagyis a GGb formák nem pusztultak el folyamatosan alámerített elhelyezés esetén sem, ezért megvizsgáltam, hogy a folyadékkultúra alkalmas-e a szaporításukra. Ehhez 3 féle citokinin: BA, BR, MT és egy citokininhatású vegyület, a TDZ négyféle koncentrációját vizsgáltam. A koncentrációk megválasztása során kisebb mennyiségeket alkalmaztam, mint amit szilárd táptalaj esetén általában alkalmaznak, mert a folyékony tápközegben jobb az oldott anyagok diffúziója, ezért nem alakulnak ki lokális hiányok a közegben a növény anyagfelvétele miatt, másrészt a növény számára könnyebb az anyagfelvétel is folyékony közegböl. A kísérleti táptalajok összetételét a 8. táblázat mutatja:

8. táblázat. A folyékony táptalajok összetétele

\begin{tabular}{|c|c|c|c|c|c|}
\hline \multicolumn{4}{|c|}{ citokininek $\left(\mathrm{mgL}^{-1}\right)$} & $\operatorname{auxin}\left(\mathrm{mgL}^{-1}\right)$ & \multirow{2}{*}{ alaptáptalaj } \\
\hline BA & BR & MT & TDZ & NES & \\
\hline 0,05 & 0,05 & 0,05 & 0,05 & \multirow{4}{*}{0,1} & \multirow{4}{*}{$\begin{array}{c}1 / 2 \times \mathrm{MS}^{+} \\
20 \mathrm{gL}^{-1} \\
\text { szacharóz }\end{array}$} \\
\hline 0,1 & 0,1 & 0,1 & 0,1 & & \\
\hline 0,2 & 0,2 & 0,2 & 0,2 & & \\
\hline 0,5 & 0,5 & 0,5 & 0,5 & & \\
\hline
\end{tabular}

Jelmagyarázat: BA - benziladenin, BR - benziladenin-ribozid, MS - Murashige-Skoog táptalaj, MT metatopolin, NES - naftilecetsav, TDZ - thidiazuron

A kísérlet tehát 16 kezelésből állt, kezelésenként 10-15 csőben helyeztem el csövenként minimum $3 \mathrm{GGb}$ telepet. A rotátor férőhelyeinek száma korlátozta az egyszerre elvégezhető kezelések számát, így 4-szer 2 hónapos periódusokban zajlott a kísérlet elvégzése, egy-egy periódus során egyféle citokinin különböző koncentrációinak tesztelése zajlott 40-60 csővel. Mindegyik kezelés esetén 2 hónap után értékeltem a GGb telepeket. Mértem a telepátméröt, a telep tömegét és a POD-aktivitást, számláltam a GGb-k telepenkénti darabszámát és bonitálással megállapítottam a telepek állapotát.

\subsubsection{Emelt makroelem- és szacharóz koncentráció hatásának vizsgálata}

Agarral szilárdított táptalajon, $0,5 \mathrm{mgL}^{-1}$ BA és $0,1 \mathrm{mgL}^{-1} \mathrm{NES}$ jelenléte mellett megvizsgáltam, hogy a táptalajban alkalmazott makroelem- és szacharózmennyiség befolyással van-e a GGb telepek fejlődésére. 1× és 2× MS makroelem koncentrációkat kombináltam 20 és $40 \mathrm{gL}^{-1}$ szacharózzal, kontrollként pedig 0,5× MS makroelemeket használtam szacharóz nélkül. Kezelésenként 14 lombikba, lombikonként 3 GGb telepet helyeztem el, melyek 3-5 GGb-t tartalmaztak. A kísérletet 2 hónap után értékeltem, melynek során megmértem a GGb telepek hosszúságát, szélességét, megszámoltam a telepekben a GGb-k számát, megmértem a telepek tömegét, és felmértem az állapotukat a korábban ismertetett kategóriarendszerrel. A lemért 
adatokból kiszámoltam az egyes GGb-k fajlagos tömegét, és alakindexet számoltam. Biokémiai paraméterként a klorofill- és karotinoidtartalmat, peroxidázaktivitást és szárazanyag-tartalmat határoztam meg.

\subsubsection{Triazol típusú növekedési retardánsok hatásának vizsgálata}

A triazol-vegyületek vizsgálata akkor merült fel, amikor kísérleten kívül, egy paklobutrazolt is tartalmazó kis citokinin koncentrációjú pihentető táptalajra kerültek a GGb telepek és néhány hónap után egyöntetü regeneráció következett be. Ezt előkísérletként tekintettem. $24 \mathrm{GGb}$ telep került $0,5 \mathrm{mgL}^{-1} \mathrm{PBZ}-\mathrm{t}, 0,2 \mathrm{mgL}^{-1} \mathrm{BA}-\mathrm{t}$ és $0,1 \mathrm{mgL}^{-1} \mathrm{NES}$-at tartalmazó táptalajra, melyekből korábban 12 telep $0,1 \mathrm{mgL}^{-1} \mathrm{KIN}-$ vagy $0,2 / 0,4 \mathrm{mgL}^{-1} \mathrm{BA}$ tartalmú táptalajon, és 12 telep $3 \mathrm{mgL}^{-1} \mathrm{GA}_{3}$-tartalmú táptalajon volt. Az előbbi 12 telep mindegyikén 6 hónap után sarjjá regenerálódott részek voltak, míg a $\mathrm{GA}_{3}$-tartalmú táptalajról származó GGb-telepek egyike sem regenerálódott. A regenerálódott telepeken POD-aktivitást mértem az egyes regenerálódási fázisokban. A tervezett kísérletek során elöször a paklobutrazol használható koncentrációját mértem fel egy szélesebb koncentrációtartomány vizsgálatával $\left(0,25 ; 0,5,1 ; 2 \mathrm{mgL}^{-1}\right)$, egyéb növekedésszabályozók nélkül, agarral szilárdított 1/2× MS táptalajon, $20 \mathrm{gL}^{-1}$ szacharózzal. 3-5 GGb-t tartalmazó részekre vágtam a GGb-telepeket és hármasával helyeztem el őket 14 Erlenmeyer-lombikban kezelésenként. A tenyészeteket 8 és 12 hét után értékeltem, felmértem a GGb telepek állapotát, a 12. héten pedig POD-aktivitást mértem a GGb telepekből 3-3 mintán kezelésenként. A flurprimidol vizsgálata során négyféle koncentrációban $\left(0,05 \mathrm{mgL}^{-1}, 0,1 \mathrm{mgL}^{-1}, 0,2 \mathrm{mgL}^{-1}\right.$ és $\left.0,5 \mathrm{mgL}^{-1}\right)$ került a kísérleti táptalajokba, $0,2 \mathrm{mgL}^{-1}$ BA és $0,1 \mathrm{mgL}^{-1} \mathrm{NES}$ használata mellett, agarral szilárdított $1 / 2 \times \mathrm{MS}$ makro- és teljes mikroelem összetétel, $20 \mathrm{gL}^{-1}$ szacharóz mellett. A táptalajokra kezelésenként $30 \mathrm{GGb}$ telep került, 10 lombikban, lombikonkét 3 teleppel. 3 hónap elteltével mértem a telepek morfológiai jellemzőit (GGb-szám, telepátmérő, teleptömeg, fejlődési állapot), és mintát vettem kezelésenként külön-külön a rügyszerü állapotban (n=6-10) lévő GGb-kből POD-aktivitás vizsgálathoz. A FP-kezelések utóhatás vizsgálatához a kezelésekről származó egészséges vagy regenerálódó telepeket passzáltam $0,5 \mathrm{mgL}^{-1} \mathrm{BA}$ és $0,1 \mathrm{mgL}^{-1} \mathrm{NES}$-tartalmú szilárd 1/2× MS, $20 \mathrm{gL}^{-1}$ szacharóz táptalajra, és 5 hónap elteltével a regenerálódás különböző fázisaiban lévő GGb-kből (n=2-3) mintát vettem a POD vizsgálathoz, valamint megszámoltam a teljesen regenerálódott telepek számát.

\subsection{A Spathiphyllum sarjtenyészeteivel folytatott kísérletek}

A sarjtenyészetekkel folytatott kísérletek célja kettős volt; egyrészt annak vizsgálata, hogy in vitro sarjtenyészetekből kiindulva is létrehozható-e a GGb forma, másrészt pedig a sarjtenyészeten keresztüli organogenetikus szaporítási forma körülményeinek optimalizálása - az 
irodalomban a legtöbb szerző a különböző növekedésszabályozók típusaival és koncentrációival foglalkozik, de egyéb tényezőkkel, mint makroelem-koncentráció, szénhidrátellátás, kevésbé.

\subsubsection{Különböző szénhidráttípusok hatásának vizsgálata}

Négy különböző szénhidráttípus, két diszacharid (szacharóz és maltóz) és két monoszacharid (glükóz és fruktóz) alkalmasságát vizsgáltam hajtástenyészetek energiaellátásának szempontjából. Ezek a cukrok $20 \mathrm{gL}^{-1}$ koncentrációban kerültek 4,5 g agarral szilárdított MS táptalajba, 0,5 $\mathrm{mgL}^{-1} \mathrm{BA}$ és $0,1 \mathrm{mgL}^{-1} \mathrm{NES}$ mellett. Kezelésenként 21 lombikba, lombikonként kettesével helyeztem el regisztrált tömegü 2 leveles hajtáscsúcsokat. A kísérlet időtartama 10 hét volt, ezalatt 2 hetente történt a növényekből mintavétel, összesen 5 alkalommal. A növényi mintákon a tömegnövekedést, a sarj- és levélszám és magasság alakulását, a levélfelület növekedését mértem. Meghatároztam a növények nettó $\mathrm{CO}_{2-}$ asszimilációs rátáját, sztómakonduktanciáját és transzspirációját.

\subsubsection{Emelt makroelem- és szénhidrát-koncentrációk hatásának vizsgálata}

A 16 hétig tartó kísérlet során szacharóz és fruktóz kétféle koncentrációját (20 és $40 \mathrm{gL}^{-1}$ ) kombináltam 1/2×-es, 1×-es és 2×-es MS makroelem koncentrációkkal, hogy megvizsgáljam az emelt makroelem/szénhidrátforrás hatását a sarjtenyészetek hosszabb távú kultúrában tarthatóságára táptalajcsere nélkül. Tízféle kezelést alkalmaztam összesen, melyeket a 9. táblázat foglal össze. Kis hormonkoncentráció mellett neveltem a növényeket.

9. táblázat. A táptalajok összetétele az emelt makroelem- és szénhidrát-koncentrációk vizsgálata során alkalmazott kezelésekben

\begin{tabular}{|c|c|c|c|c|}
\hline $\begin{array}{l}\text { Kezelés } \\
\text { száma }\end{array}$ & $\begin{array}{l}\text { MS makroelem } \\
\text { koncentrációja }\end{array}$ & $\begin{array}{c}\text { Szénhidrát } \\
\text { típusa }\end{array}$ & $\begin{array}{c}\text { Szénhidrát } \\
\text { koncentrációja }\end{array}$ & $\begin{array}{c}\text { Növekedésszabályozók } \\
\text { koncentrációja }\end{array}$ \\
\hline 1 & $1 \times$ & szacharóz & $20 \mathrm{gL}^{-1}$ & \multirow{10}{*}{$\begin{array}{c}0,5 \mathrm{mgL}^{-1} \mathrm{BA}+0,1 \mathrm{mgL}^{-1} \\
\mathrm{NES}\end{array}$} \\
\hline 2 & $2 x$ & szacharóz & $20 \mathrm{gL}^{-1}$ & \\
\hline 3 & $1 \times$ & szacharóz & $40 \mathrm{gL}^{-1}$ & \\
\hline 4 & $2 x$ & szacharóz & $40 \mathrm{gL}^{-1}$ & \\
\hline 5 & $0,5 x$ & szacharóz & $20 \mathrm{gL}^{-1}$ & \\
\hline 6 & $0,5 x$ & szacharóz & $40 \mathrm{gL}^{-1}$ & \\
\hline 7 & $1 \times$ & fruktóz & $20 \mathrm{gL}^{-1}$ & \\
\hline 8 & $2 x$ & fruktóz & $20 \mathrm{gL}^{-1}$ & \\
\hline 9 & $1 \times$ & fruktóz & $40 \mathrm{gL}^{-1}$ & \\
\hline 10 & $2 x$ & fruktóz & $40 \mathrm{gL}^{-1}$ & \\
\hline
\end{tabular}

Jelmagyarázat: BA - benziladenin, MS - Murashige-Skoog táptalaj, NES - naftilecetsav 
A növényeket kettesével helyeztem el a kísérlet elején Erlenmeyer-lombikokba, kezelésenként legalább 14 lombikot használva. A kísérletet 16 hét letelte után értékeltem, ekkor lemértem a fejlődött sarjtelepek tömegét, a benne lévő sarjak számát, megmértem a legmagasabb sarjat, megszámoltam a sarjankénti levélszámot, megmértem a legkifejlettebb sarjakon a kifejlett levelek hosszát és szélességét a levél alakindex kiszámításához. A sarjak szárazanyag-tartalmát, klorofilltartalmát és a szacharózos táptalajon növekvő növények POD-aktivitását is vizsgáltam.

\subsubsection{A paklobutrazol hatásának vizsgálata}

A triazol típusú növekedési retardáns paklobutrazol hatását a sarjtenyészeteken is vizsgáltam annak megállapítására, hogy kivált-e akkora mértékü hajtástörpülést, ami GGb formuláció képződését idézheti elő. Ehhez a sarjtenyészetekből származó válogatott, azonos méretű (2-3 leveles) hajtásokat helyeztem kettesével Erlenmeyer-lombikokba, az alkalmazott táptalaj 1/2× makroelem-koncentrációjú MS táptalaj volt kiegészítve $20 \mathrm{gL}^{-1}$ szacharózzal, $0,1 \mathrm{mgL}^{-1} \mathrm{NES}$-val, és $0,25 \mathrm{mgL}^{-1}$ meta-topolinnal. A minimális citokinin jelenléte a triazol mellett fontos ahhoz, hogy a triazol-citokinin szinergizmushatás létrejöhessen. A PBZ-mentes kontrolltáptalaj mellett 4 kezelést hoztam létre, melyekben a táptalajt kiegészítettem 0,$25 ; 0,5 ; 1$ és $2 \mathrm{mgL}^{-1}$ PBZ-lal. A növényeket 100 napig neveltem ezeken a táptalajokon, majd morfológiailag értékeltem őket (sarjszám, magasság, levélszám, gyökérszám, sarjteleptömeg), megmértem a klorofilltartalmukat, POD-aktivitásukat, és a fotoszintézishez kapcsolódó gázcseréjüket. Ezután 50 napig növekedésszabályozótól mentes táptalajon pihentettem őket, majd vizsgáltam a különböző PBZ-koncentrációk utóhatását a morfológiai paraméterek, a gázcsere mérésével, valamint sztómaanatómiai vizsgálatokat végeztem. A növényállomány vizsgálatok után megmaradt részét akklimatizáltam.

\subsection{A kísérleti növénytenyészetek eredete}

A kísérletekhez felhasznált in vitro növényanyagot a BCE Dísznövénytermesztési és Dendrológiai Tanszék laboratóriumában tartották fenn. A Spathiphyllum floribundum 'Petite' sarj és GGb tenyészeteit 2001-ben indították. Fenntartásuk kis makroelem- (1/2× MS makro) és citokininkoncentráció $\left(0,1 \mathrm{mgL}^{-1} \mathrm{KIN}\right.$ vagy $\left.\mathrm{BA}\right)$ mellett történt a kísérletek közötti időszakokban. A steril kultúra indításokhoz kereskedelemből származó valamint in vitro nevelt és akklimatizált, majd üvegházban virágoztatott 'Petite' és nem meghatározott, egységes fajtájú anyanövényeket is felhasználtam.

\subsection{A laboratóriumi nevelés körülményei}

A tenyészetek fenntartása és a kísérletek lefolytatása a laboratórium fényszobájában történt, napi 16 órás, 2500 lx megvilágítás (hideg- és melegfehér fluoreszcens fénycsövek 
kombinációja) mellett, 2010-ig $24 \pm 10^{\circ} \mathrm{C}$, utána $24 \pm 4{ }^{\circ} \mathrm{C}$ hőmérsékleten. A nevelőpolcokon a fénycsövek a tenyészedények felett helyezkedtek el, tehát azok felülröl kapták a fényt. A steril munkákat egy lamináris fülkében (BA-900, Debreceni Finommechanikai Vállalat) végeztem. A kísérletekhez felhasznált tenyészedények agarral szilárdított táptalajok használata esetén 200 $\mathrm{cm}^{3}$-es széles szájú Erlenmeyer-lombikok és szintén $200 \mathrm{~cm}^{3}$-es bébiételes üvegek voltak, folyékony táptalaj esetén pedig $100 \mathrm{~cm}^{3}$-es kémcsövek (20 cm hosszú, $3 \mathrm{~cm}$ átméröjü). A tenyészedények lezárása folpack fóliával történt, 3 rétegben.

A hajtástenyészetek akklimatizálását klímakamrában (MLR-351H, Sanyo Electric Co. Ltd., Japán) végeztem, 1:1 arányú tőzeg és perlit keverékbe ültetve a növényeket. A közeg pH-ja 6 volt. A klímakamrában 16:8 órás fotóperiódus mellett, $\sim 9$ klx fényintenzitás, 25/25 ${ }^{\circ} \mathrm{C}$ hőmérséklet és $70 \%$ relatív páratartalom mellett tartottam a növényeket 8 hétig.

\subsection{A táptalajok}

A táptalajok, amennyiben nincs másként jelölve, MURASHIGE et SKOOG (1962) receptje alapján készültek, a makroelem-koncentrációt felezve. A felhasznált cukorforrás a legtöbb esetben szacharóz volt, háztartási cukor formájában (Koronás kristálycukor). A szilárdításhoz 4,5 gL $\mathrm{gL}^{-1}$ Plant Agar-t használtam (Duchefa Biochemie B.V., Hollandia). A táptalajok pH-ját 5,6-re állítottam be autoklávozás előtt 0,1 mólos $\mathrm{KOH}$ vagy citromsav oldatával. Az autoklávozás $121^{\circ} \mathrm{C}$-on, 0,1 MPa túlnyomáson 35 percig történt.

A hőérzékeny paklobutrazol (Duchefa Biochemie B.V., Hollandia) táptalajba keverése autoklávozás után, steril szüréssel történt (Millipore $0,22 \mu \mathrm{m}$ pórusátmérőjü nitrocellulóz membránszürővel) a még folyékony, kézmeleg táptalajokba, 50 v/v\%-os etil-alkoholos törzsoldat formájában. A flurprimidol (Duchefa Biochemie B.V., Hollandia) autoklávozható anyag, ezért nem kellett sterilen szürni. Törzsoldatához a fehér kristályos anyagot először dimetilszulfoxidban oldottam fel, majd $50 \mathrm{v} / \mathrm{v} \%$-os etanollal oldatot készítettem. A kész törzsoldat 1 \%-nyi dimetil-szulfoxidot tartalmazott, így a táptalajokba 0,5-5 ppm mennyiség került a választott koncentráció függvényében.

\subsection{Morfológiai paraméterek mérése}

\subsubsection{GGb telepek}

A GGb telepek morfológiai jellemzőinek meghatározása steril körülmények között, a lamináris boxban történt. A kiterjedésbeli tulajdonságok (telepátmérő, hosszúság illetve szélesség) meghatározása a steril munkafelületként szolgáló petricsésze alá helyezett milliméterpapír segítségével történt egész milliméterre kerekítve. 
A telepen belüli GGb darabszám, a regenerálódott sarjak és képződött gyökerek számának meghatározása vizuális számlálással történt.

A GGb teleptömeg mérése a lamináris fülkébe behelyezhető laboratóriumi gyors bemérőmérleg (JL1502-G, Mettler-Toledo, Svájc) segítségével történt két tizedes pontossággal gramban. A fajlagos GGb tömeget a GGb telep tömegének és GGb darabszámának hányadosaként számoltam ki.

A GGb telepek alakindexének meghatározása az alábbi képlet segítségével történt: $|\mathrm{x}-\mathrm{y}| / \max \{\mathrm{x}, \mathrm{y}\}$, ahol $\mathrm{x}$ és y a telepek hosszúsági és szélességi adatai voltak.

A GGb telepek fejlődési állapotát bonitálással határoztam meg, az alábbi osztályokat létrehozva: 1 - elpusztult telepek, 2 - pusztulásnak indult, barnuló részeket legalább fele arányban tartalmazó telepek, 3 - egészséges, fejlődö, zöld vagy zöldes árnyalatú telepek, 4 - a sarjregeneráció megindulásának jeleit mutató telepek, 5 - teljesen sarjjá regenerálódott részeket tartalmazó telepek (15. ábra).
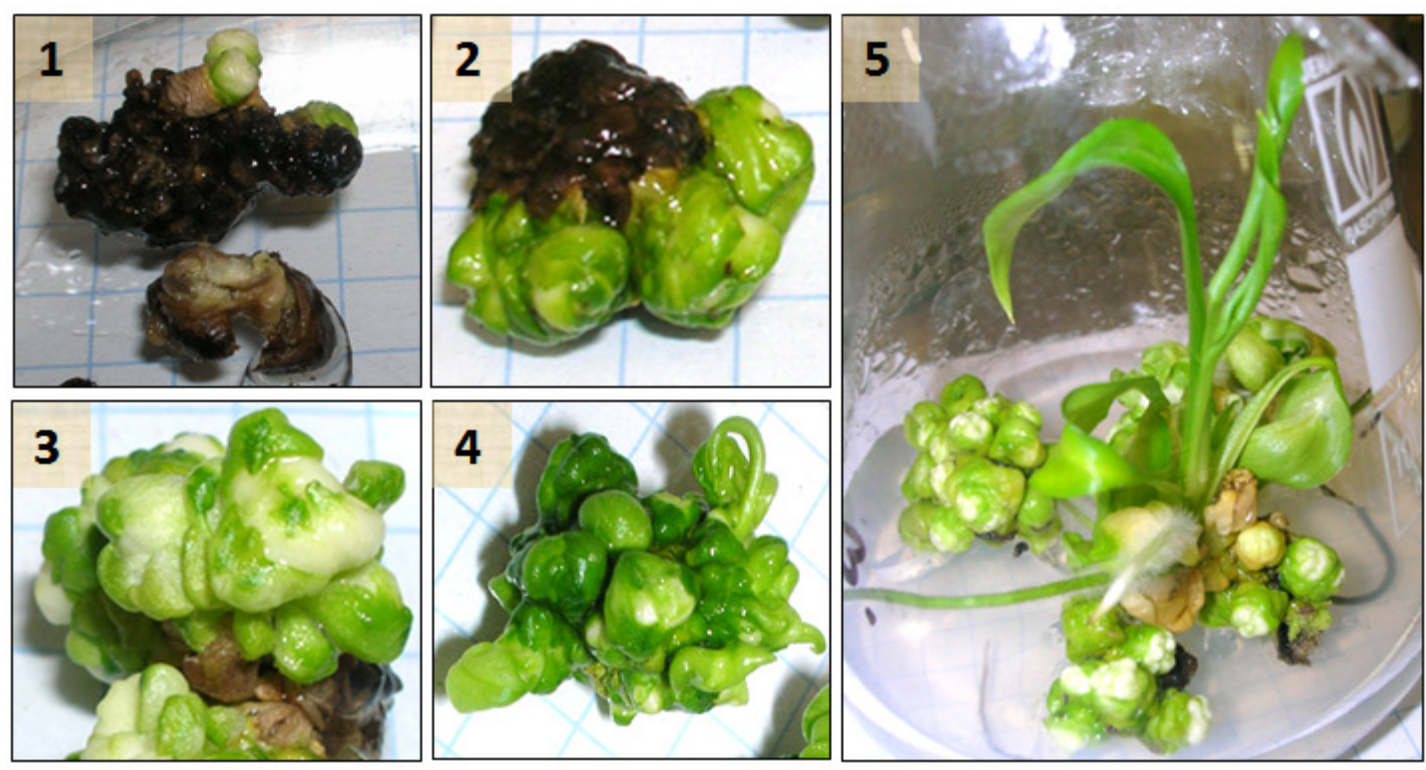

15. ábra. A GGb-telepek különböző fejlődési állapota Spathiphyllum floribundum 'Petite' in vitro tenyészetében.: 1 - elpusztult telepek, 2 - pusztulásnak indult, barnuló részeket legalább fele arányban tartalmazó telepek, 3 - egészséges, fejlődő, zöld vagy zöldes árnyalatú telepek, 4 - a sarjregeneráció megindulásának jeleit mutató telepek, 5 - teljesen sarjjá regenerálódott részeket tartalmazó telepek.

\subsubsection{Sarjtenyészet}

Hajtástenyészetek esetén a sarjak, levelek és gyökerek számának meghatározása vizuális úton, számlálással történt. A sarjmagasság mérését nem steril körülmények között közvetlenül milliméterpapírra helyezéssel oldottam meg, steril körülmények között pedig egy steril 
petricsészére tettem a növényeket, és az az alá elhelyezett milliméterpapírral mértem a kiterjedésüket.

A sarjak összlevélfelületének méréséhez a leveleket egyesével eltávolítottam a növényről és 600 dpi felbontás mellett beszkenneltem (Scanjet 7400 C, Hewlett Packard), területüket pedig a GIMP 2.8.6 képszerkesztő szoftverrel határoztam meg. Abban az esetben, ha a sarjakra még szükség volt más mérésekhez is, a levélfelületet közelítő módszerrel határoztam meg, melyet a következő fejezetben részletezek.

A levelek alakindexének meghatározása az alábbi képlet segítségével történt: $|\mathrm{x}-\mathrm{y}| / \max \{\mathrm{x}, \mathrm{y}\}$, ahol $\mathrm{x}$ és y a levelek hosszúsági és szélességi adatai voltak, amelyeket milliméterpapír segítségével határoztam meg.

\subsection{Gázcsereparaméterek vizsgálata}

Infravörös gázanalizátor (LCi Portable Photosynthesis System, ADC BioScientific Ltd., Egyesült Királyság) segítségével mértem az egész sarjak gázcseréjét, meghatározva a növények nettó $\mathrm{CO}_{2}$ asszimilációs rátáját, $\mathrm{CO}_{2}$ sztómakonduktanciáját és transzspirációját. A mérés során a müszer hengeres kiképzésü örökzöld méröfejét (conifer chamber) használtam, amelybe belefért egy-egy lombikból kivett sarj teljes egészében. A mérés mindig a napi fényperiódus második harmadában történt. Mivel a gázcseremérések során használt LCi berendezés a conifer chamber mérőfejjel mérésenként előre megadott adatok híján konstans felületre vonatkoztatott mérési eredményeket ad, ezért a transzspirációt, a sztómakonduktanciát és a nettó $\mathrm{CO}_{2}$-asszimilációs rátát újraszámoltam a berendezés által mért gázcsere-alapparaméterekből, figyelembe véve az egyes növények közelítő levélfelületét. Ebben az esetben a növények levélfelületét a tömegükből egy lineáris regressziós egyenlet segítségével becsültem $\left(\mathrm{R}^{2}=0,89\right)$, melyet úgy kaptam, hogy az adott kísérletben szereplő kontrollkezelés táptalajával megegyező táptalajon nevelt növényeknél mértem rendszeres időközönként a tömeget és a pontos levélfelületet az előző fejezetben leírt módszer alapján, majd felállítottam az adatok alapján egy függvényt.

\subsection{Szövettani vizsgálatok}

A sztómaanatómiai vizsgálatokhoz negatív levélfelszíni lenyomatokat készítettem színtelen, nitrocellulóz alapú kozmetikai lakk (Miss Sporty) segítségével a hajtáscsúcson lévő legfelső teljesen kifejlett levelekröl, hogy rögzítsem a sztómák állapotát. A levelekről $30 \mu \mathrm{m}$ vastagságú félvékony keresztmetszetet is készítettem mikrotóm (Hyrax M40, Carl Zeiss Microimaging Gmbh, Németország) segítségével, a metszés előtt a növényekről szedett leveleket $37 \%$-os formaldehid - cc. ecetsav - 70 \%-os etanol (5-5-90 \% arányú) keverékében fixáltam, majd 70\%-os etanol, Ottix Shaper és Ottix Plus oldatok (DiaPath S.p.A., Olaszország) felhasználásával víztelenítettem. A mintákat paraffinba ágyaztam Microm STP 120 (Thermo 
Fisher Scientific Inc., USA) beágyazóautomata illetve Microm EC350-2 (Thermo Fisher Scientific Inc., USA) beágyazórendszer segítségével. Sem a levélfelszíni lenyomatokat, sem a keresztmetszeti preparátumokat nem festettem, hanem fáziskontraszt üzemmódban fénymikroszkóp (Axio Imager 2, Carl Zeiss Microimaging Gmbh, Németország) segítségével optikailag kontrasztosítottam, és a méréseket az Axiovision LE 4.8.2.0 szoftver segítségével végeztem.

\subsection{Biokémiai paraméterek vizsgálata}

A klorofill- és karotinoidtartalom meghatározása ARNON (1949) módszere alapján történt. Analitikai mérlegen (Explorer Pro 64, OHAUS Europe, Svájc) 3 tizedes pontossággal (gram) lemért 100-150 mg frisstömegü növényi mintát homogenizáltam $4{ }^{\circ} \mathrm{C}$ alatti hömérsékletre hütött dörzsmozsarakban, kvarchomokkal, késhegynyi $\mathrm{Na}_{2} \mathrm{CO}_{3}$ jelenlétében 80 v/v\%-os acetonnal. A homogenizált mintákat feltöltöttem $10 \mathrm{ml}$ végtérfogatra $80 \mathrm{v} / \mathrm{v} \%$-os acetonnal, és $4{ }^{\circ} \mathrm{C}$-on, $1000 \mathrm{rpm}$ sebességgel centrifugáltam (5418 R, Eppendorf AG., Németország) 10 percig. A felülúszó abszorbanciáját spektrofotométerrel (GeneSys VIS-10, Thermo Fisher Scientific Inc., USA) mértem $\lambda_{1}=663, \lambda_{2}=644, \lambda_{3}=480 \mathrm{~nm}$ hullámhosszakon, majd a kapott értékekből az alábbi képlet segítségével számoltam a klorofilltartalmat:

$\mu$ g klorofill/g frisstömeg $=\left(20,2 * \mathrm{~A}_{644}+8,02 * \mathrm{~A}_{663}\right) * \mathrm{~V} / \mathrm{w}$, ahol:

$\mathrm{A}_{\mathrm{x}}$ - adott hullámhosszon mért abszorbancia

$\mathrm{V}$ - a minta végtérfogata

w - a bemért és homogenizált növényi frisstömeg

A szárazanyagtartalom-meghatározáshoz $80{ }^{\circ} \mathrm{C}$-on szárítottam a növényi mintákat 24 órán keresztül, előtte-utána a tömegüket pedig analitikai mérlegen (Explorer Pro 64, OHAUS Europe, Svájc) mértem meg 3 tizedes pontossággal.

A peroxidáz (EC 1.11.1.7) (POD) aktivitását SHANNON et al. (1966) módszerével mértem spektrofotometriásan $(\lambda=460 \mathrm{~nm}), \mathrm{H}_{2} \mathrm{O}_{2}$ szubsztrát jelenlétében ortodianizidin kromogén reagens segítségével (moláris abszorpciós együttható az oxidált ortodianzidin esetében: $\varepsilon=11,3 \mathrm{mM}^{-1} \mathrm{~cm}^{-1}$ ). A méréshez a mintákat $300 \mathrm{mg}$ körüli friss növényi szövetböl készítettem $4{ }^{\circ} \mathrm{C}$ alatti hömérsékletre hütött dörzsmozsarakban kvarchomok és $0{ }^{\circ} \mathrm{C}$-os foszfát-puffer $(\mathrm{pH}=6,5)$ segítségével, majd centrifugáltam $4{ }^{\circ} \mathrm{C}$-on $13500 \mathrm{rpm}$ sebességgel 20 percig. A felülúszóból 1-10 $\mu$ l-nyi mennyiségeket mértem ki a reakcióelegyhez, amelynek végtérfogata $1760 \mu \mathrm{l}$ volt, tartalmazott $20 \mu \mathrm{l}$ ortodianizidin-oldatot $(10 \mathrm{mg} / \mathrm{ml}$ metanolban oldva $), 30 \mu \mathrm{l}$ 0,3\%-os $\mathrm{H}_{2} \mathrm{O}_{2}$-t és nátriumacetát-ecetsav puffert $(\mathrm{pH}=4,5) . \mathrm{Az}$ enzimaktivitás mérése szobahőmérsékleten történt 2 percig, 10 másodpercenként vettem fel az abszorbanciaértékeket. Az enzimaktivitás kiszámításához az 1 perc alatti abszorbanciaváltozás értékét megszoroztam a vizsgált minta reakcióelegyben történő hígulásával, és leosztottam az ortodianizidin moláris 
abszorpciós együtthatójával. A kapott $\mathrm{U} / \mathrm{ml}$ enzimaktivitás mértékegységet a minta frisstömegének ismeretében átszámoltam U/mg értékekre.

\subsection{A statisztikai értékeléshez felhasznált módszerek}

Az adatok feldolgozása Microsoft Excel 14.0 változatával történt, a statisztikai tesztek számítása pedig IBM SPSS Statistics 20 szoftverrel. A statisztikai értékelés során a szóráshomogenitás és normális adateloszlás feltételének teljesülése esetén egytényezős teljes véletlen elrendezésű varianciaanalízist, az előfeltételek sérülése esetén pedig robusztus Welchféle varianciaanalízist alkalmaztam. A páronkénti összehasonlításhoz rendre Tukey-Kramer vagy Games-Howell tesztet használtam 95\%-os szignifikanciaszint mellett. 


\section{Eredmények}

\subsection{Steril kultúra indítási kísérletek}

Az első kultúraindítási kísérlet során a sterilizálási eljárás nem bizonyult kellően hatásosnak, az összes explantátum körül fertőzés alakult ki a táptalajokon, melyek túlnyomó többsége bakteriális eredetü volt. A második indítás során a megmaradt anyanövények rügyeit metszettem ki, és ezeket használtam fel explantátumként (16. ábra).

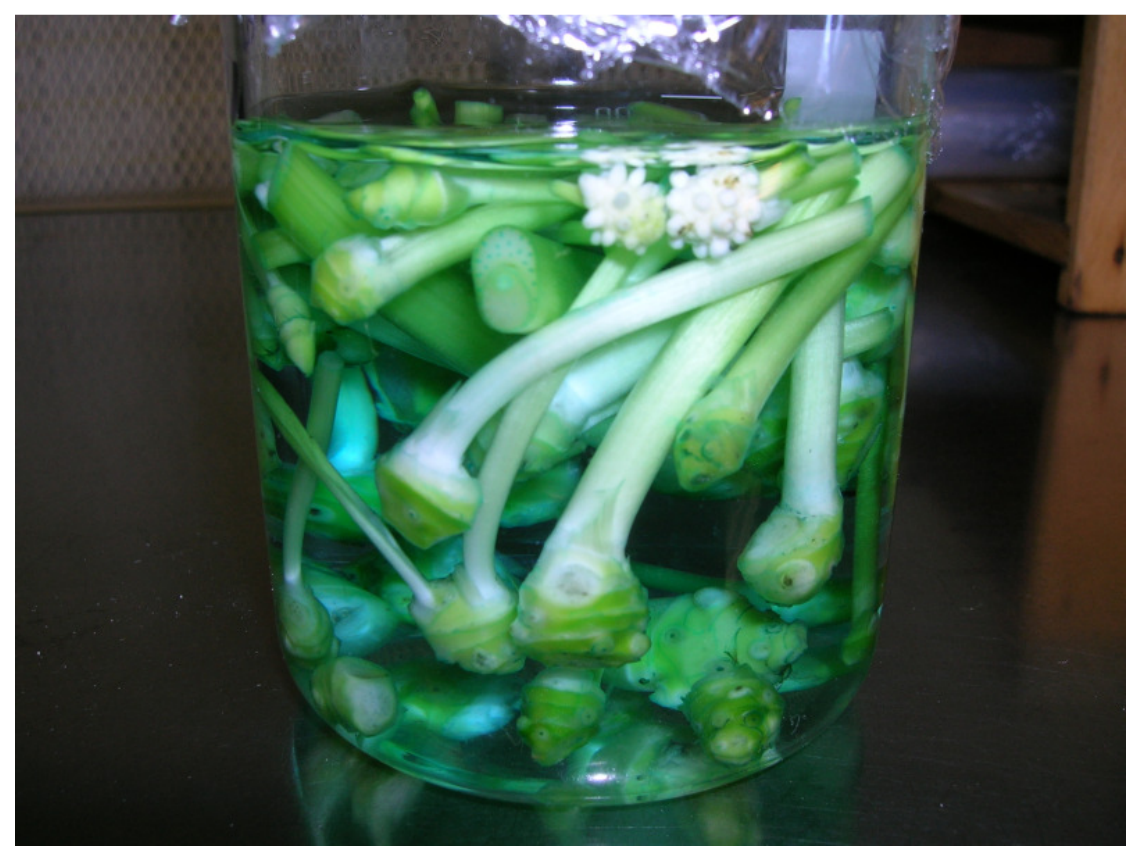

16. ábra. A második indítás során felhasznált, rügyet tartalmazó kimetszett szárdarabok Spathiphyllum floribundum 'Petite' fajta esetén.

A fertőtlenítési eljárást a benomil-oldatos beöntözéssel, a másfél helyett 16 órás antibiotikumos áztatással, és a Hypo helyett Clorox használatával próbáltam meg javítani, de az eredmény itt is negatív lett, az explantátumok nagy része 1 héten belül, a maradék részük pedig folyamatosan a passzálások során fertőzött lett, endogén jelenlévő kórokozók miatt.

A harmadik kultúraindítási kísérlet során a fertőtlenítési eljárást több ponton módosítottam, az antibiotikumos kezelés időtartamát tovább növeltem 16-ról 24 órára, és az összetételét is módosítottam. A Clorox-oldatot 50\%-os koncentrációban, és kétszer annyi ideig alkalmaztam, valamint higany(II)-kloridos áztatást is bevezettem. Az etanolos bemártást elhagytam, csak a buroklevéllel fedett virágtorzsák esetén hagytam meg a lelángolás miatt. A módosított fertőtlenítési eljárással már sikeresen sterilizáltam az explantátumokat. Az inokuláló táptalajon egy explantátum mutatta a gombás fertőzés jeleit, a többi mind steril maradt, egy hét 
után kerültek az indítótáptalajokra. Egy hónap után ismét értékeltem a fertőtlenítés hatását. A felmérés eredményét mutatja az alábbi, 10. táblázat:

10. táblázat. A harmadik kultúraindítás során a Spathiphyllum (fajta nem ismert) explantátumok fertőződési aránya

\begin{tabular}{|c|c|c|c|c|c|c|}
\hline \multirow[b]{2}{*}{ Táptalaj } & \multirow[b]{2}{*}{$\begin{array}{c}\text { Expl. } \\
\text { Fejlettsége }\end{array}$} & \multirow[b]{2}{*}{ Lombikok } & \multirow[b]{2}{*}{$\begin{array}{l}\text { Expl. } \\
\text { szám } \\
\text { (db) }\end{array}$} & \multicolumn{2}{|c|}{ Fertı zés (db expl.) } & \multirow{2}{*}{$\begin{array}{c}\text { Fertı zés } \\
\text { az összes } \\
\text { (100 db) } \\
\text { expl.-ra } \\
\text { vonatkoztatva } \\
(\%)\end{array}$} \\
\hline & & & & bakt. & gombás & \\
\hline \multirow{3}{*}{ „M1” } & 1 & 9 & 9 & 1 & - & $1 \%$ \\
\hline & 2 & 9 & 9 & - & - & - \\
\hline & 3 & 7 & 7 & 1 & 3 & $4 \%$ \\
\hline \multirow{3}{*}{ „M2” } & 1 & 8 & 8 & 1 & 2 & $3 \%$ \\
\hline & 2 & 9 & 9 & 1 & - & $1 \%$ \\
\hline & 3 & 8 & 8 & 2 & 1 & $3 \%$ \\
\hline \multirow{3}{*}{ „M3” } & 1 & 8 & 8 & 1 & 1 & $2 \%$ \\
\hline & 2 & 9 & 9 & - & - & - \\
\hline & 3 & 7 & 7 & 1 & 2 & $3 \%$ \\
\hline \multirow{2}{*}{ „B1” } & 2 & 10 & 20 & 4 & - & $4 \%$ \\
\hline & 3 & 3 & 6 & - & 4 & $4 \%$ \\
\hline összesen & & & 100 & 12 & 13 & $25 \%$ \\
\hline
\end{tabular}

Fertőződések tehát továbbra is előfordultak, de az explantátumok háromnegyed része esetében a módszer sikeresnek bizonyult. Az $1 \mathrm{mgL}^{-1}$ BA kiegészítésü táptalajon 3 explantátum fenolosodás következtében megbarnult és elpusztult. A többi explantátum életben maradt. A fejlettebb (2-es és 3-as) explantátumokon a virágok elkezdtek kinyílni a lombikban, és illatukat még a 3 réteg Folpack fólián keresztül is lehetett érezni. Az összes explantátum másfél hónappal a táptalajra helyezés után bezöldült és megduzzadt, de regeneráció jeleit nem mutatták. Két hónap elteltével egyes explantátumok szöveti szerkezete fellazult és elkezdtek szétesni, a többi explantátum egyben maradt. Regenerációt 3 hónap elteltével sem tapasztaltam, ekkor friss táptalajra helyeztem át a fel nem lazult szövetű virágtorzsákat. További 3 hónapig figyeltem még a virágtorzsákat, és az 5. hónapban egy explantátumnál sikerült megfigyelni a torzsán az egyes virágok között regenerálódó törpehajtásokat (17. ábra), melyek a regeneráció korai stádiumában lévő GGb formákra hasonlítottak. 


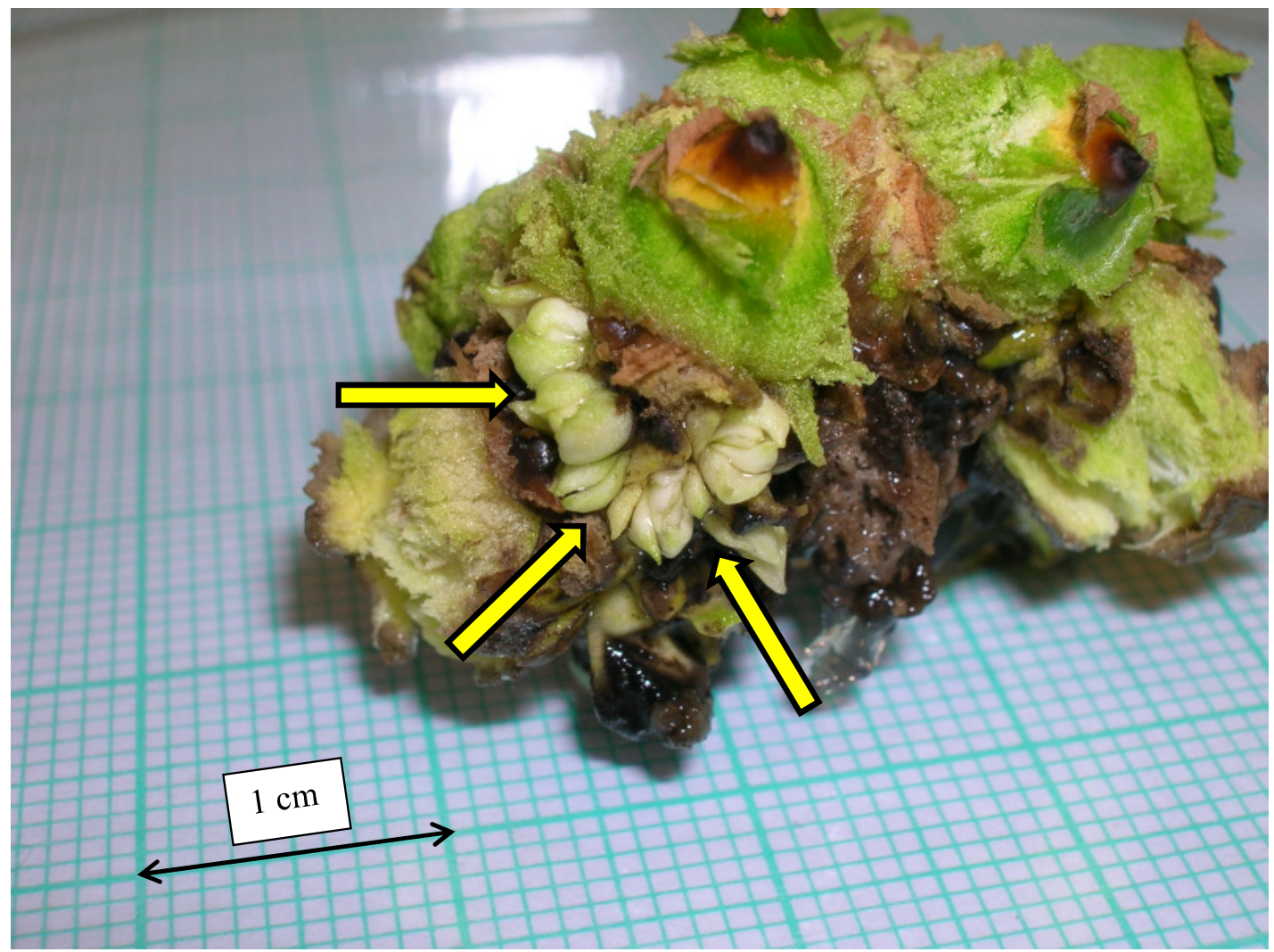

17. ábra. Regeneráció a harmadik kultúraindításnál a nem ismert nevü Spathiphyllum fajta virágtorzsáján $3 \mathrm{mgL}^{-1}$ MT tartalmú táptalajon.

Ezeket a sarjkezdeményeket leválasztva és friss, citokinintartalmú táptalajra helyezve rendes GGb formát kaptam (18. ábra).

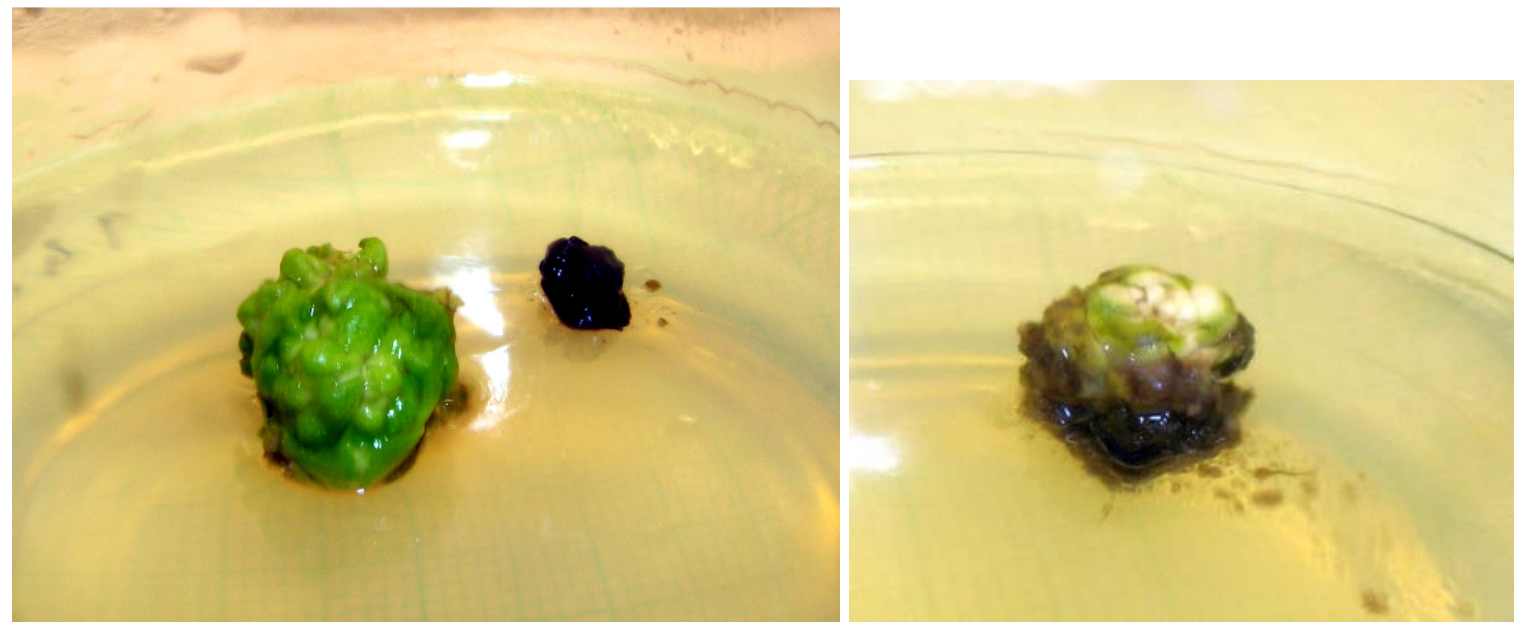

18. ábra. Kialakult GGb telepek a leválasztott törpe sarjkezdeményekből, melyek $3 \mathrm{mgL}^{-1} \mathrm{MT}$ tartalmú táptalajon regenerálódtak virágtorzsából.

A többi explantátum esetében 6 hónap elteltével sem figyeltem meg regenerációt, és nem neveltem tovább őket, mert mindegyik pusztulni kezdett. 
A negyedik és ötödik indítás alkalmával a 'Petite' fajta és egy másik floribundum fajta virágtorzsáját használtam fel explantátumként. Az antibiotikum-kezelést elhagytam a sterilizálási folyamatból, és az explantátumokat $3 \mathrm{mgL}^{-1} \mathrm{MT}$-tartalmú táptalajra helyeztem. A nem ismert nevü fajta virágtorzsáin regenerációt nem tapasztaltam, de a 'Petite' fajta esetében az indító táptalajra helyezés után 1 hónappal jól kivehetően GGb formációk kezdtek kialakulni a virágtorzsán az egyes virágok között (19. ábra), melyek aztán növekedésnek indultak (20. ábra).

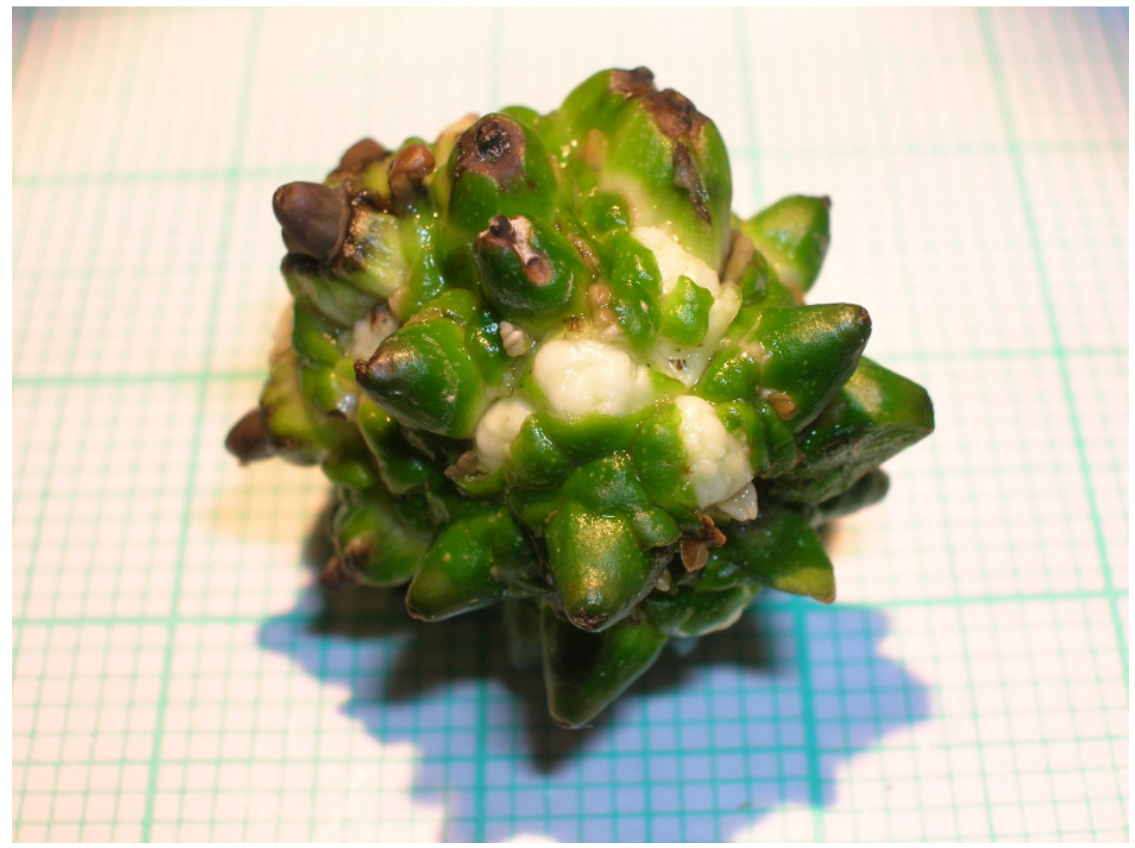

19. ábra. Kialakuló GGb a Spathiphyllum floribundum 'Petite' fajta virágtorzsáján 1 hónappal a $3 \mathrm{mgL}^{-1} \mathrm{MT}$ tartalmú indító táptalajra helyezés után.

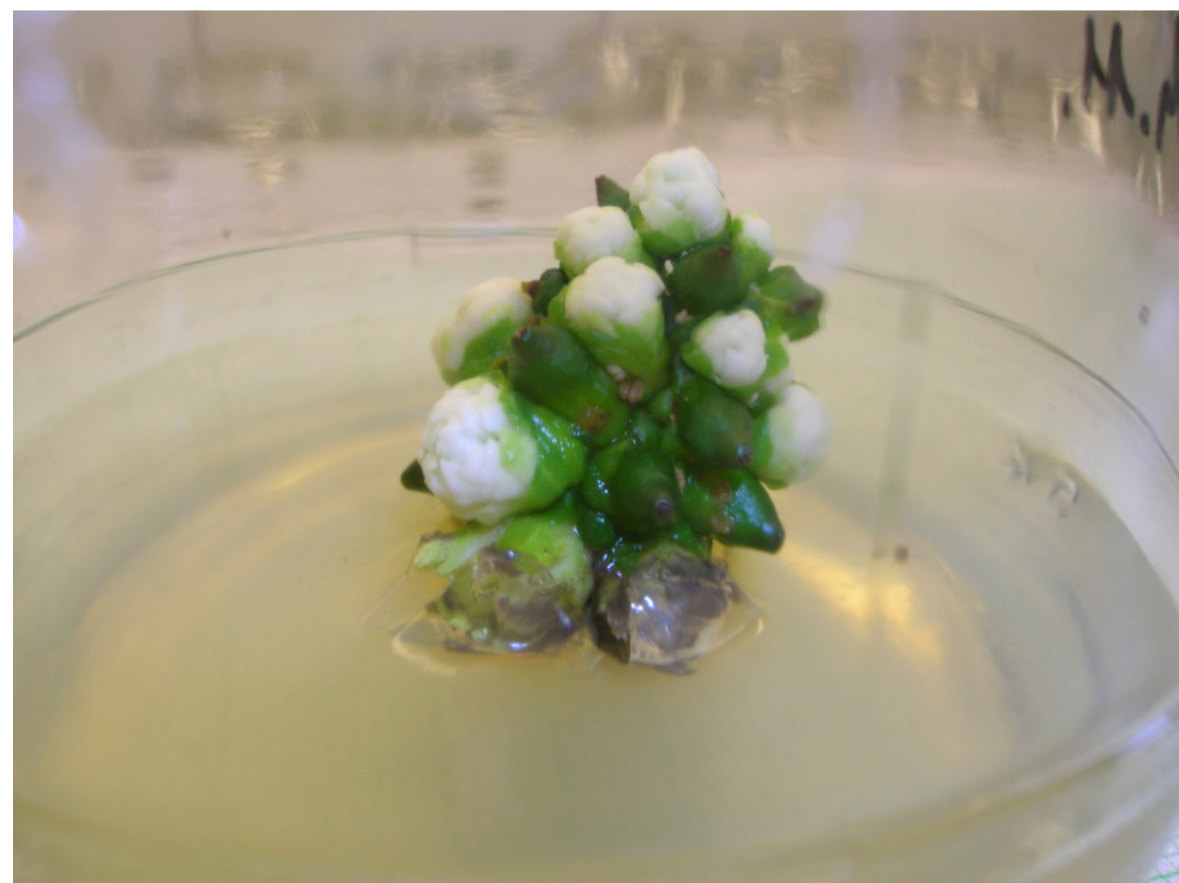

20. ábra. Továbbfejlődő GGb a Spathiphyllum floribundum 'Petite' fajta virágtorzsáján 2 hónappal a $3 \mathrm{mgL}^{-1} \mathrm{MT}$ tartalmú indító táptalajra helyezés után. 
A negyedik indítás során a 'Petite' fajta 13 explantátumából 6-nál tapasztaltam regeneráció megindulását 2 hónapon belül, mindegyik GGb formában történt. Az ötödik indításnál 15 explantátumból 1-nél kezdett GGb formálódni 2 hónapon belül. A sterilitás a negyedik indításnál 70 \% körül alakult (13 explantátumból 4-nél nem sikerült a fertőtlenítés), míg az ötödik indításnál $47 \%$ volt (15 explantátumból 8-nál történt fertőzés).

Az explantátumként felhasznált virágtorzsákon, különösen a 'Petite' fajta esetén, néhány esetben megfigyeltem szabálytalan szerveződést (21. ábra), melyek hasonlítottak egy kialakuló GGb formához. Összefüggést azonban nem figyeltem meg, hogy ezen szabálytalan alakulású torzsavirágzatból származó explantátumok hajlamosabbak lennének-e GGb-t képezni, mint a szabályos torzsavirágzatok.

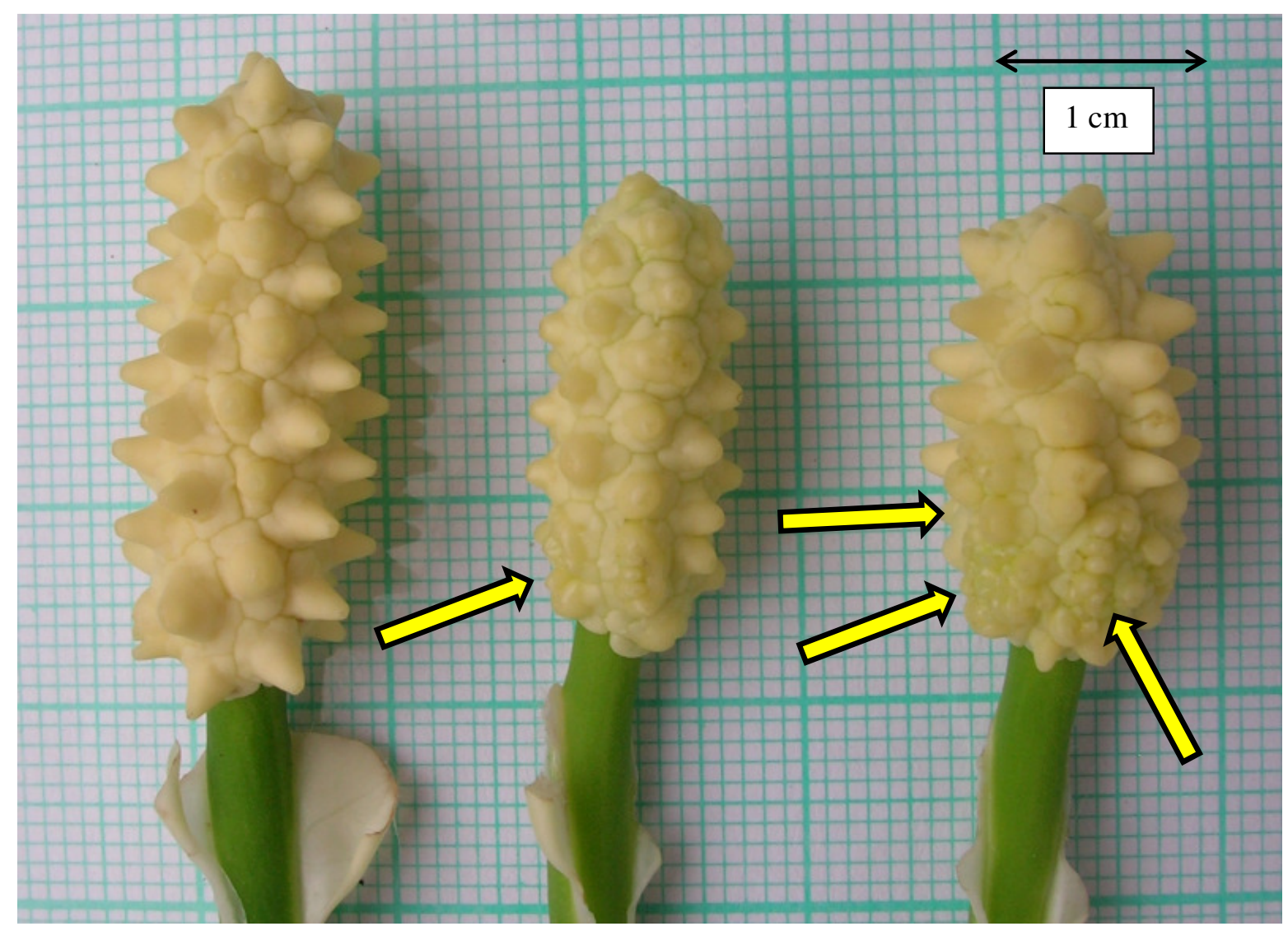

21. ábra. Az explantátumként felhasznált Spathiphyllum floribundum 'Petite' fajta torzsavirágzatai (balról jobbra: szabályos alakulású; kevés hibával rendelkező; torz torzsavirágzat).

A szabálytalan torzsával rendelkező virágzatok közül néhányat azonban nem használtam explantátumként, hanem megfigyeltem a további virágzásfenológiájukat. A virágzás végére, mire a spadix és a spatha elkezdett bezöldülni, a torzsa szabálytalan részei megduzzadtak és kifejezett GGb formát alakítottak ki (22. ábra és 23. ábra). A torzsán lévő képződmények in vivo nem alakultak át sarjakká a megfigyelt esetekben. 


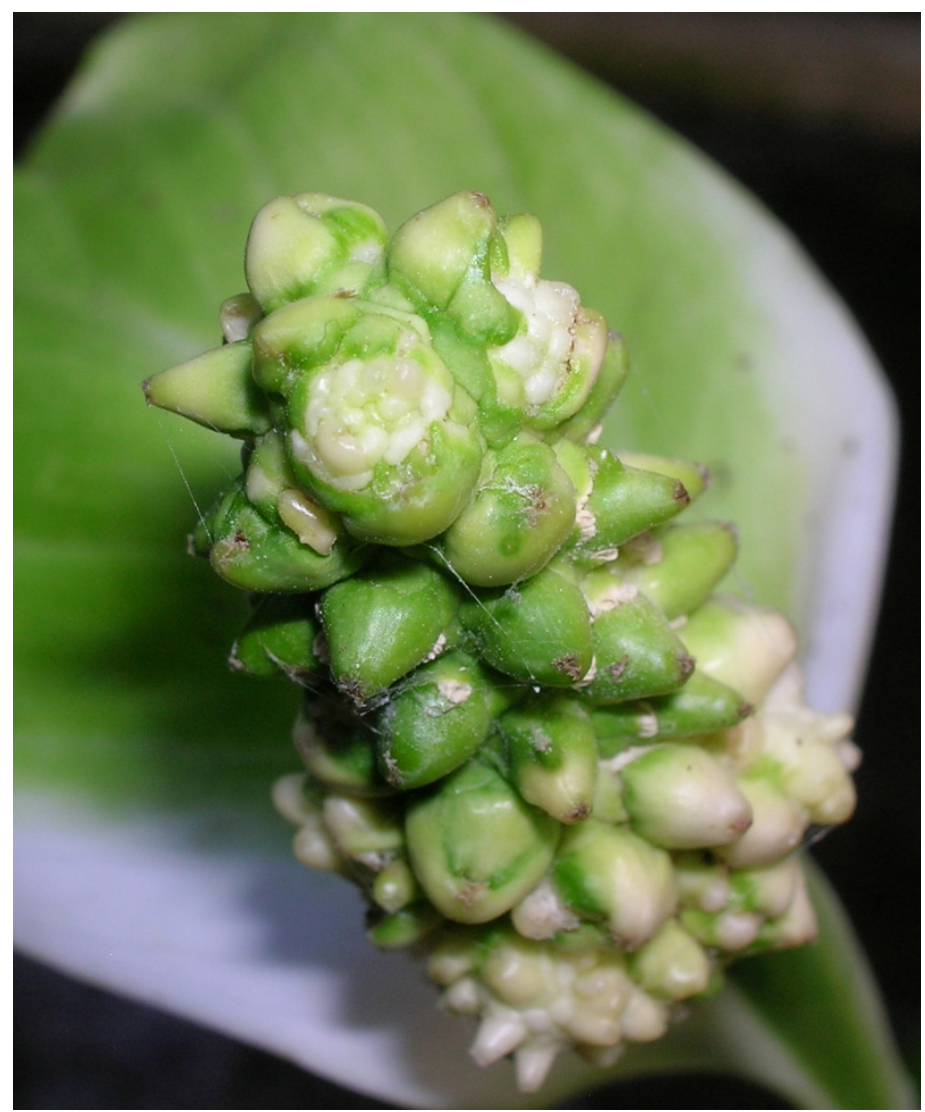

22. ábra. Spathiphyllum floribundum 'Petite' anyanövény virágzatában in vivo, kezelés nélkül kialakult, kezdeti fejlődési stádiumban lévő GGb-telepek.

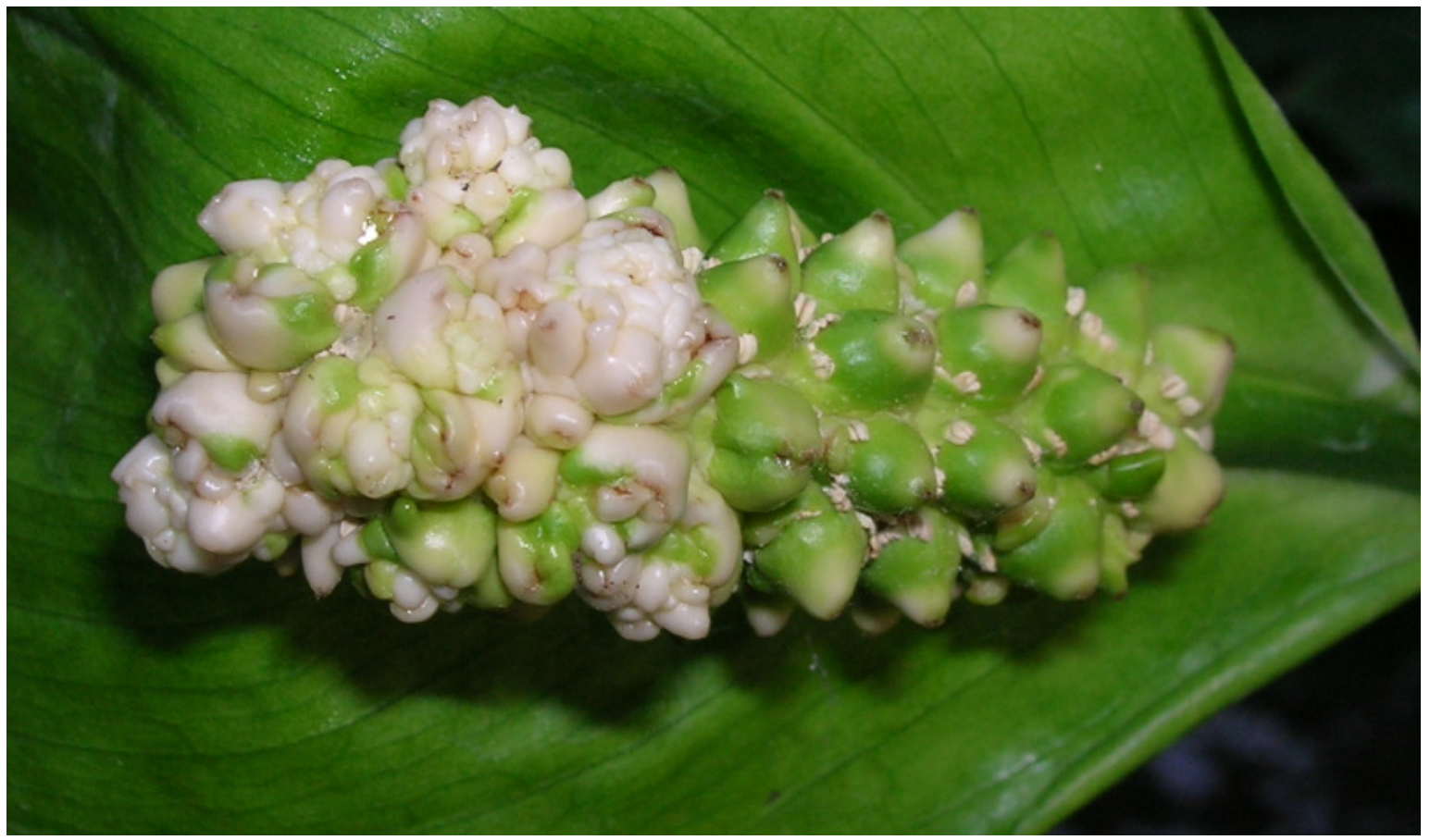

23. ábra. Spathiphyllum floribundum 'Petite' anyanövény virágzatában in vivo, kezelés nélkül kialakult, előrehaladott fejlődési állapotú GGb-telepek. 


\subsection{A Spathiphyllum GGb-telepekkel folytatott kísérletek}

\subsubsection{Eltérő NES koncentrációk vizsgálata}

A statisztikai elemzés alapján elmondható, hogy a GGb-telepátmérők, az individuális GGb-k mérete és a telepekben lévő GGb testek számának alakulása között nem mutatható ki szignifikáns különbség a különböző NES-koncentrációk ${ }^{1}$ hatására. A GGb-telepek növekedésének üteme azonosnak tekinthető az eltérő NES-koncentrációk hatására (24. ábra).

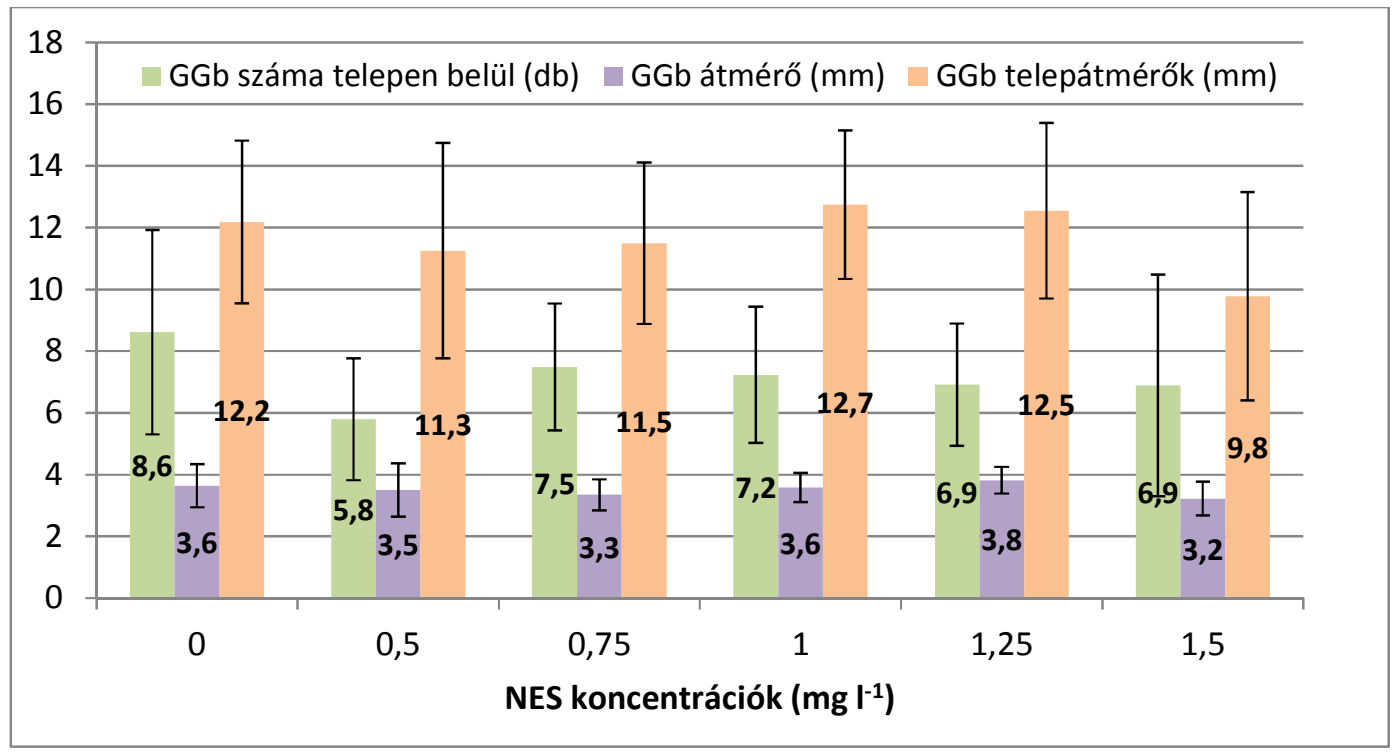

24. ábra. A NES-koncentrációk hatása a GGb-telepek növekedésére Spathiphyllum floribundum 'Petite' in vitro tenyészetében 6 hónap után.

A regenerálódás mértékét vizsgálva azonban található eltérés a kezelések között. A 15. ábra mutatja az állapotkategóriákat, melyek alapján a regenerálódás mértékét és a telepek általános állapotát jellemzem. A legtöbb sarjjá regenerálódott telepet a 6 . hónap végén a legkisebb NES-koncentráció $\left(0,5 \mathrm{mgL}^{-1}\right)$ mellett találtam, 22,6 \%-ot. A NES-at nem tartalmazó táptalajon 16,7\%-a regenerálódott a telepeknek. A 0,75 és $1 \mathrm{mgL}^{-1} \mathrm{NES}$ koncentráció mellett már csak 5,6 ill. 8,6 \%-a, a két legmagasabb $\left(1,25\right.$ és 1,5 $\left.\mathrm{mgL}^{-1}\right)$ koncentráció mellett pedig nem találtam egyetlen sarjjá alakult telepet sem. Ezen a két koncentráción a telepek 48-60\%-a pusztulásnak indult/elpusztult, tehát ez a két koncentráció már túl magas. A telepek fenntartásához a vizsgált táptalajok közül a $0,75 \mathrm{mgL}^{-1}$ NES-kiegészítésű lehet az ideális, ezen a telepek 83,3 \%-a megmaradt a GGb-állapotban, csupán 2,8\%-uk pusztult el, és 5,6 \%-uk regenerálódott sarjjá (25. ábra).

\footnotetext{
${ }_{1}^{1} 1 / 2 \mathrm{MS}, 20 \mathrm{gL}^{-1}$ szacharóz, $0,25 \mathrm{mgL}-1$ BA kiegészítve $0 ; 0,5 ; 0,75 ; 1 ; 1,25 ; 1,5$ mgL-1 NES-val
} 


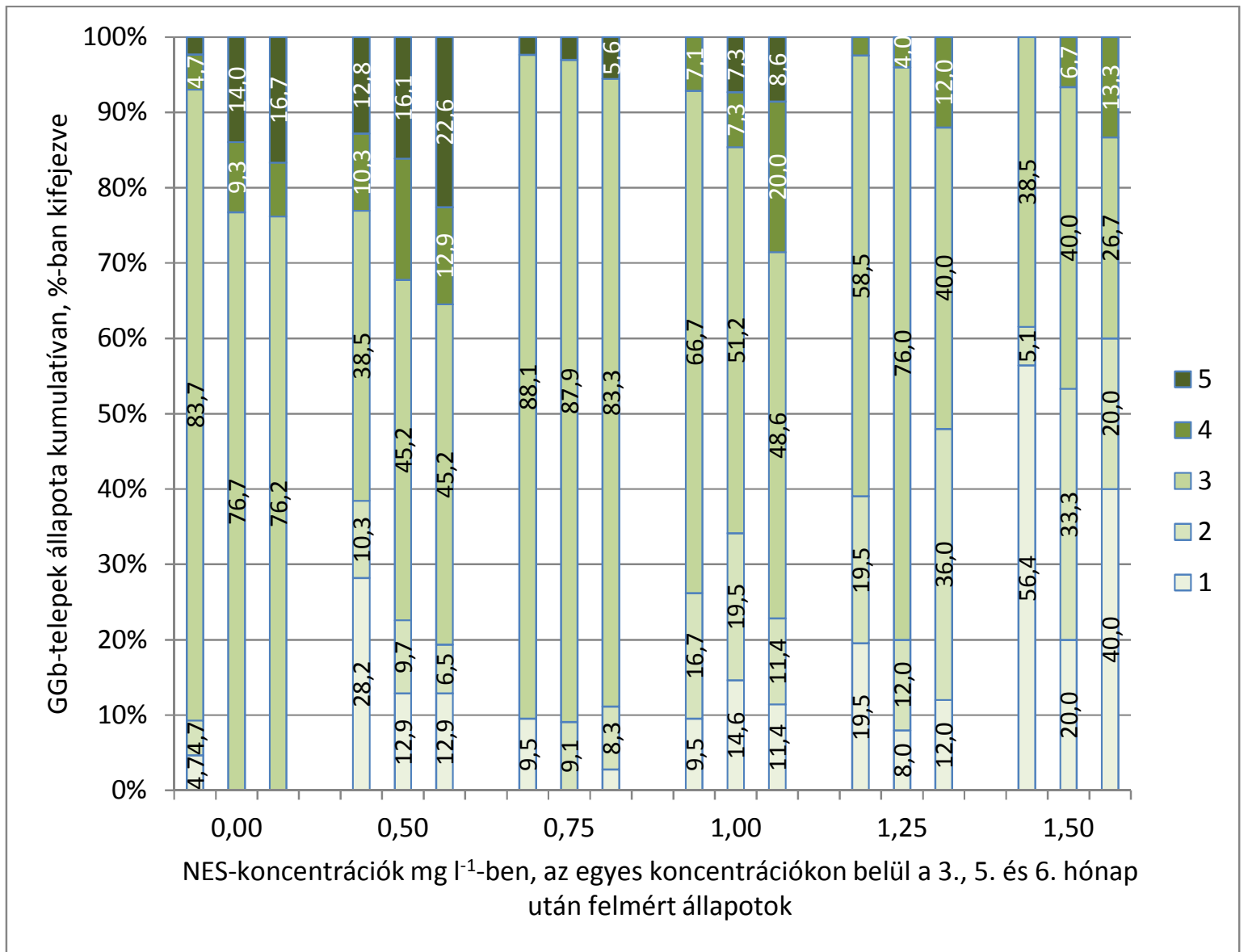

25. ábra. A NES-koncentrációk hatása a GGb-telepek állapotának alakulására a kísérlet indítása utáni 3., 5. és 6. hónapban Spathiphyllum floribundum 'Petite' in vitro tenyészetében. Az állapotkategóriák jelentése: 1 - elpusztult telepek, 2 - pusztulásnak indult, barnuló részeket legalább fele arányban tartalmazó telepek, 3 - egészséges, fejlődő, zöld vagy zöldes árnyalatú telepek, 4 - a sarjregeneráció megindulásának jeleit mutató telepek, 5 - teljesen sarjjá regenerálódott részeket tartalmazó telepek.

A gyökér jelenléte nem korlátozódott kizárólag a regenerálódott állapotra, kivételes esetekben látható volt a rügy (3-as) és a pusztulásnak indult (2-es) fázisokban is, bár ez utóbbinál valószínüleg még a 3-as fázisban alakulhatott ki. Nagyon ritka előfordulása miatt következtetést nem lehet levonni a jelenséggel kapcsolatban, de az megállapítható, hogy a GGb-k képesek a hajtásregenerációt megelőzően vagy annak hiányában is gyökeret fejleszteni. A regenerálódó telepeknél az esetek túlnyomó többségében a hajtásfejlődés megindulása után kezdődött csak el a gyökérkialakulás és -fejlődés.

Azoknál a telepeknél, ahol hajtásregeneráció történt, a hajtások telepenkénti átlagos számát és hosszát, valamint a gyökérszámot és -hosszt a mellékletben a 76. ábra mutatja. A legtöbb hajtásregenerációt előidéző, $0,5 \mathrm{mgL}^{-1}$ NES-koncentrációjú táptalajon az átlagos telepenkénti 11,3 db GGb-böl (24. ábra) tehát 3,4 db alakult sarjjá (22,6 \%). Az adott kezelésnek alávetett összes GGb darabszámra vetítve ez annak csupán 6,6 \%-a. A regenerálódott sarjaknál a 
sarj- és gyökérhosszt, gyökérszámot tekintve nem lehet szignifikáns különbséget kimutatni a kis mintaelemszám és a hozzá kapcsolódó nagy szórás miatt.

\subsubsection{Különböző citokininek hatásának vizsgálata folyékony tápközegben}

Az eltérő citokinineknek ${ }^{2}$ a GGb-állapotra gyakorolt hatását mutatja be folyadékkultúrás tenyésztés mellett a 26. ábra. A BA-, BR- és MT-kiegészítésü táptalajok esetében $80 \%$ körül alakult a 3-as, vagy rügyszerü állapotban megmaradt GGb-k száma, ezzel szemben a TDZ-kezeléseknél ez csak $71 \%$. A legnagyobb mortalitást a BR-táptalajok okozták, ahol $18 \%$-a a telepeknek elpusztult vagy pusztulni kezdett. A TDZ-táptalajokon ez az arány $17 \%$, ám ezzel egy időben a telepek $9 \%$-a regenerálódni kezdett még a folyadékkultúrában, $3 \%$-uk pedig teljesen kifejlett hajtást is nevelt. Az MT-táptalajokon az 1-es és 2-es fázis aránya $16 \%$. Csak a BA-táptalajokon nem történt teleppusztulás, bár a telepek 9\%-ának állapota itt is romlani kezdett.

BA

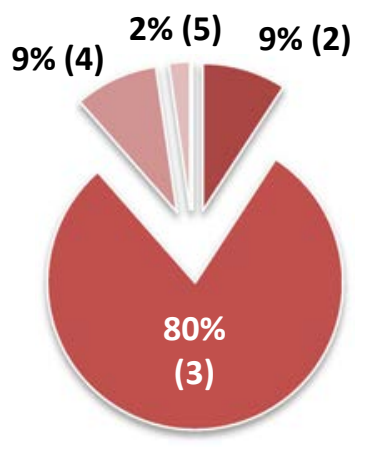

MT

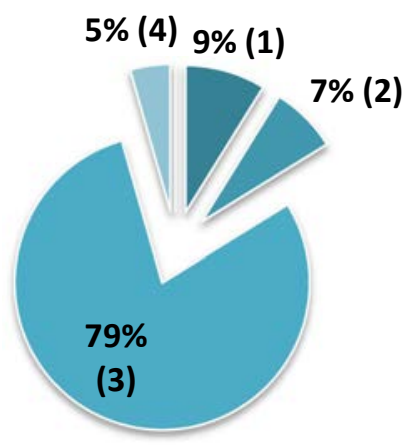

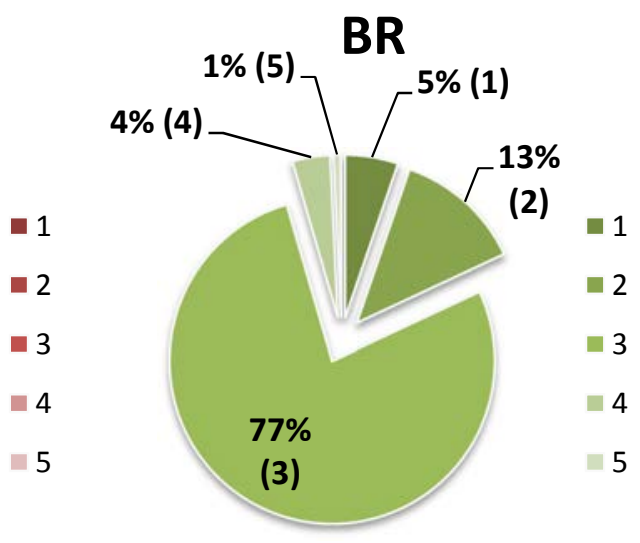

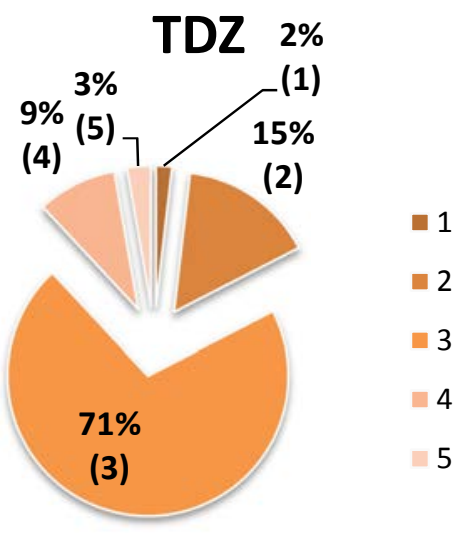

26. ábra. A folyadékkultúrában nevelt GGb-telepek állapotának változása a különféle citokinintípusok szerint csoportosítva Spathiphyllum floribundum 'Petite' in vitro tenyészetében, rövidítéseket lásd a 2 . fejezetben, számok

\footnotetext{
2 1/2× MS folyékony táptalaj, $20 \mathrm{gL}^{-1}$ szacharózzal, kiegészítve $0,1 \mathrm{mgL}^{-1} \mathrm{NES}$ és BA, BR, MT, TDZ 0,05; 0,$1 ; 0,2 ; 0,5 \mathrm{mgL}^{-1}$ koncentrációival (16 féle kombináció)
} 
jelentése: 1 - elpusztult telepek, 2 - pusztulásnak indult, barnuló részeket legalább fele arányban tartalmazó telepek, 3 egészséges, fejlődő, zöld vagy zöldes árnyalatú telepek, 4 - a sarjregeneráció megindulásának jeleit mutató telepek, 5 teljesen sarjjá regenerálódott részeket tartalmazó telepek.

A koncentrációnkénti lebontásban a 27. ábra mutatja a GGb-telepek állapotának változását a kezelések hatására. Ebből jól látszik, hogy BA használata esetén csak a legnagyobb koncentráció rontja jelentősebben a telepek állapotát, a kisebbek nem. Továbbá megfigyelhető, hogy a nagy BR- és kis MT-koncentrációk hatására egyáltalán nem következik be regeneráció. A legtöbb sarjjá alakuló telep a $0,2 \mathrm{mgL}^{-1}$ BA és $0,05 \mathrm{mgL}^{-1} \mathrm{TDZ}$ mellett figyelhető meg.

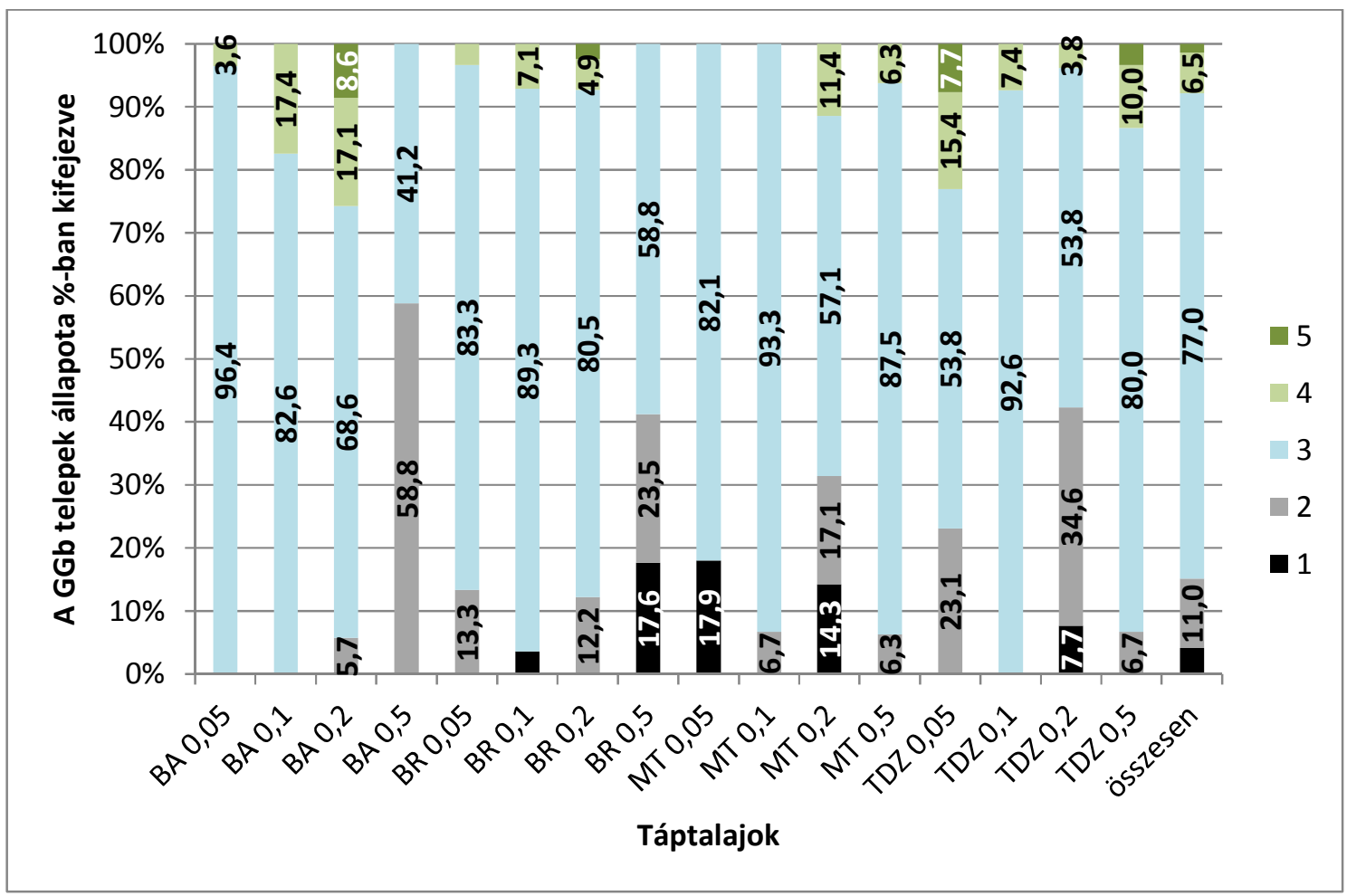

27. ábra. A GGb-telepek állapotának változása a különféle típusú és koncentrációjú citokininkezelések hatására folyadékkultúrás nevelés során Spathiphyllum floribundum 'Petite' in vitro tenyészetében, jelmagyarázat: 1 - elpusztult telepek, 2 - pusztulásnak indult, barnuló részeket legalább fele arányban tartalmazó telepek, 3 - egészséges, fejlődő, zöld vagy zöldes árnyalatú telepek, 4 - a sarjregeneráció megindulásának jeleit mutató telepek, 5 - teljesen sarjjá regenerálódott részeket tartalmazó telepek.

A folyadékkultúrában vizsgált citokinin kiegészítésü táptalajok általánosságban megtartják a GGb-telepeket a 3-as, azaz a rügyszerü állapotban, és kis arányban regenerációt vagy pusztulást idéznek elő.

A kísérlet során tapasztalt, de nem számosított megfigyeléseim szerint a folyadékkultúrás tenyésztés során a fenolosodás, vagyis a táptalajbarnulás jelensége fokozottabban lépett fel egyes esetekben, szemben az agarral szilárdított közegen történő neveléssel. Ezek többnyire akkor fordultak elö, ha a GGb-telepek szétvágásakor nem sikerült úgy osztani a telepet, hogy egy-egy GGb ne sérüljön. A probléma mértékét csökkentette, ha osztás után 2 napig hagytam a GGbtelepeket az új táptalajon, majd ismét friss táptalajra passzáltam. Ennyi idő elég volt a 
sérülésekből felszabaduló fenolos vegyületek kiázásához. A módszer nagy munkaigénye miatt azonban inkább azt a megoldást preferáltam, hogy a GGb-telepek osztásakor az esetleg megsérült GGb-k maradék részeit minél alaposabban eltávolítottam a telepröl. A fenolosodás jelenségét ez is csökkentette. A másik észrevételem az volt, hogy az itt-ott fellépő fertőzések több esetben voltak bakteriális jellegüek, mint penészgombák által okozottak, amik egyébként a passzálás során néha fellépnek. A bakteriális fertőzések nagyobb aránya arra utal, hogy valószínűleg a folyadékkultúrás tenyésztés az addig megbúvó endogén bakteriális fertőzöttséget felszínre hozta.

A folyadékkultúrában történő szaporodás hatékonyságának vizsgálatára különböző morfológiai paramétereket mértem meg, ezek közül a GGb-telep átmérőjének alakulását mutatja a 28. ábra.

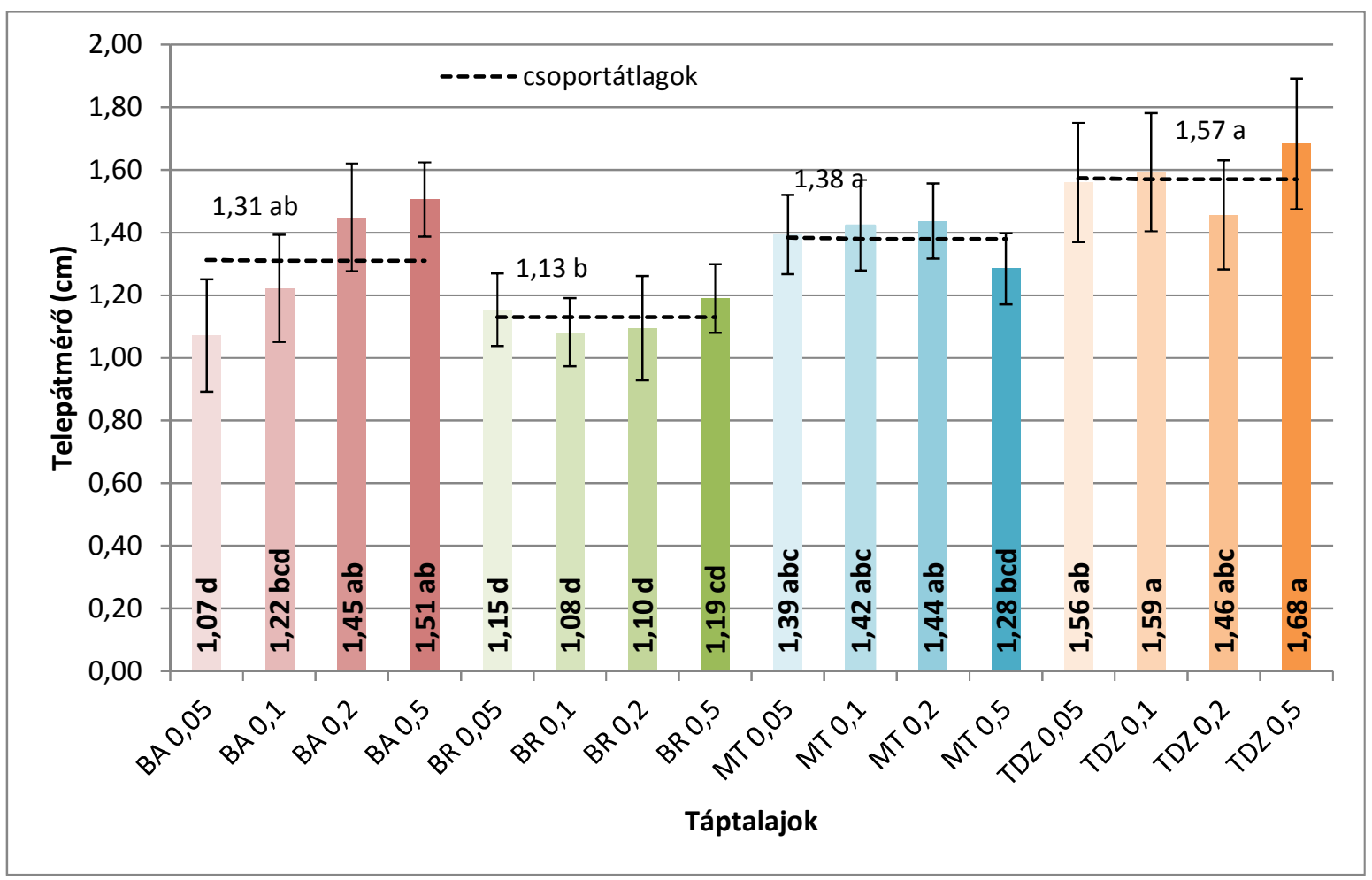

28. ábra. A GGb-telep átmérőjének alakulása a folyadékkultúrás tenyésztés során a különféle típusú és koncentrációjú citokininek hatására Spathiphyllum floribundum 'Petite' in vitro tenyészetében. Az eltérő betűk szignifikáns különbséget jelölnek, Games-Howell teszt, p<0,05.

A BA-kiegészítésű táptalajok esetében jól megfigyelhető, hogy a koncentráció növelésével a telepátmérő is nőtt, ennek oka a GGb-k telepen belüli darabszámának növekedése (29. ábra). A többi citokinin eltérő koncentrációja esetén azonban nincs jelentős különbség a telepátmérő alakulásában, ellenben a csoportátlagokat vizsgálva megállapítható, hogy a BRtáptalajok a kisebb BA-koncentráció hatásának felelnek meg, és kisebb telepátmérőt eredményeznek, míg az MT és TDZ bármelyik koncentrációjának a telepátmérőre gyakorolt hatása a nagyobb BA-koncentrációkénak felelnek meg. 
A telepeken belüli GGb-darabszám növekedése a szaporodás elsődleges jelzője, ez a nagy koncentrációjú BA-táptalajok és a TDZ-táptalajok hatására a legnagyobb (29. ábra). A BR hatására alig nő a kiindulási, 3-5 db GGb/telep szám, és a MT-táptalajok hatása sem sokkal jobb. A MT-táptalajok viszont jobban növelik a telepátmérőt (28. ábra), mint a BRtáptalajok, vagyis hatásukra az egyes GGb-k mérete nő meg, és nem a számuk. Ezzel összhangban a fajlagos GGb-tömeg is az MT-táptalajok hatására lesz a legnagyobb (30. ábra).

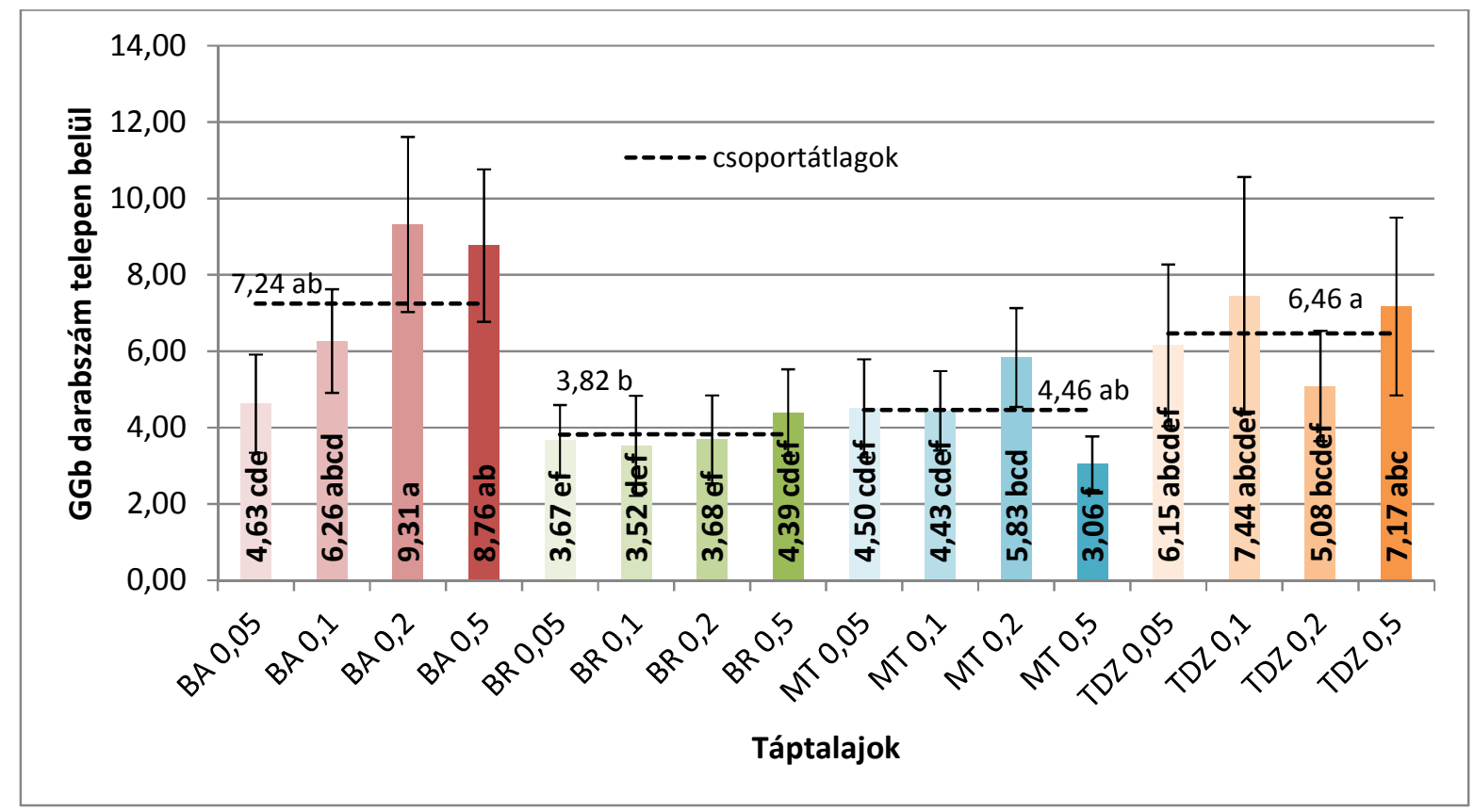

29. ábra. Az egy telepen belüli GGb-darabszám alakulása a folyadékkultúrás tenyésztés során a különféle típusú és koncentrációjú citokininek hatására Spathiphyllum floribundum 'Petite' in vitro tenyészetében. Az eltérő betúk szignifikáns különbséget jelölnek, Games-Howell teszt, p<0,05. 


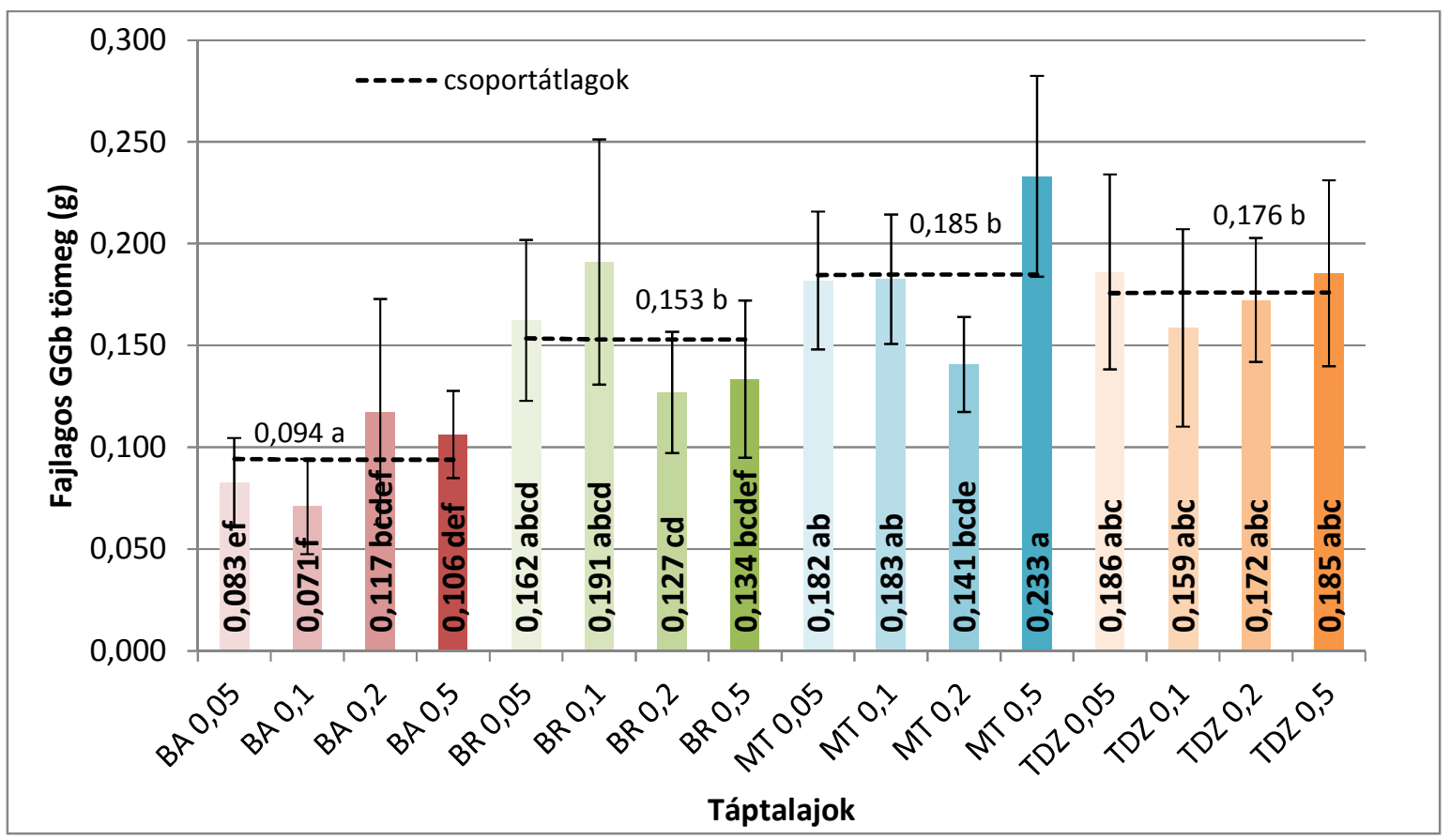

30. ábra. A fajlagos GGb-tömegek alakulása a folyadékkultúrás tenyésztés során a különféle típusú és koncentrációjú citokininek hatására Spathiphyllum floribundum 'Petite' in vitro tenyészetében. Az eltérö betúk szignifikáns különbséget jelölnek, Games-Howell teszt, p<0,05.

A fajlagos GGb tömegek (30. ábra) vizsgálatából látszik, hogy az átlagban legtöbb telepen belüli GGb-t differenciáló BA-táptalajok esetén lesz a legkisebb ez az érték, ez egyben azt is takarja, hogy ezeknek a GGb-knek az egyedi átmérője kisebb lesz, elaprózódnak. A TDZtáptalajok hatására viszont szignifikánsan nagyobb a fajlagos GGb-tömeg, mint a BAtáptalajokon, annak ellenére, hogy a TDZ-táptalajok hatására a telepen belüli GGb-szám nem sokkal kevesebb, mint a BA-táptalajok esetében (29. ábra). A TDZ hatására tehát nem aprózódik el az újonnan differenciálódó GGb-knek sem a mérete, sem a tömege. A MT hatására kialakuló legnagyobb fajlagos GGb tömegek magyarázata pedig a feljebb már említett jelenség: ezen típusú citokinin mellett a GGb-knek inkább a mérete nőtt, nem a mennyiségük.

A legnagyobb teleptömeget (31. ábra) a TDZ-táptalajok adták, illetve a BA két nagyobb koncentrációja. A térfogatnövekedést jelző telepátméröt (28. ábra) is figyelembe véve kiderül, hogy a két paraméter nagyon hasonlóan alakul az eltérő citokininek hatására is, vagyis adott mértékü térfogatnövekedéshez adekvát tömegnövekedés párosul. Ez arra utal, hogy a vizsgált növekedésszabályozók egyike sem okoz abnormális szöveti fejlődést, pl hiperhidratációt. Ennek megfelelően a 3-as fázisú GGb-telepeket vizsgálva erre utaló vizuális jelet nem is tapasztaltam. Ellenben a regenerálódni kezdő telepek esetén a kialakuló levelek mutattak némi vitrifikáltságot (32. ábra) a folyamatos bemerítés következtében. 


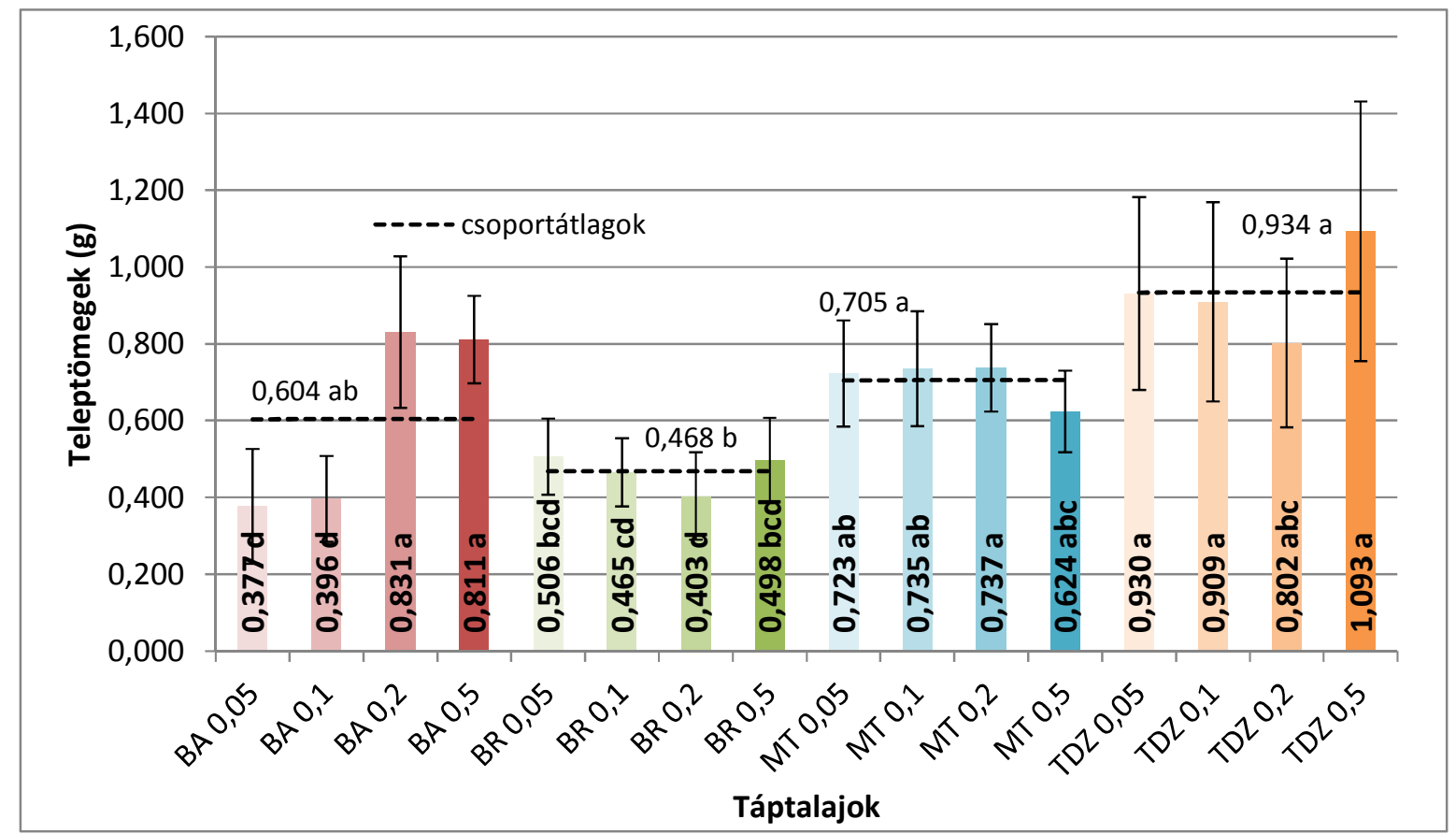

31. ábra A teleptömegek alakulása a folyadékkultúrás tenyésztés során a különféle típusú és koncentrációjú citokininek hatására Spathiphyllum floribundum 'Petite' in vitro GGb tenyészetében. Az eltérő betük szignifikáns különbséget jelölnek, Games-Howell teszt, p<0,05.
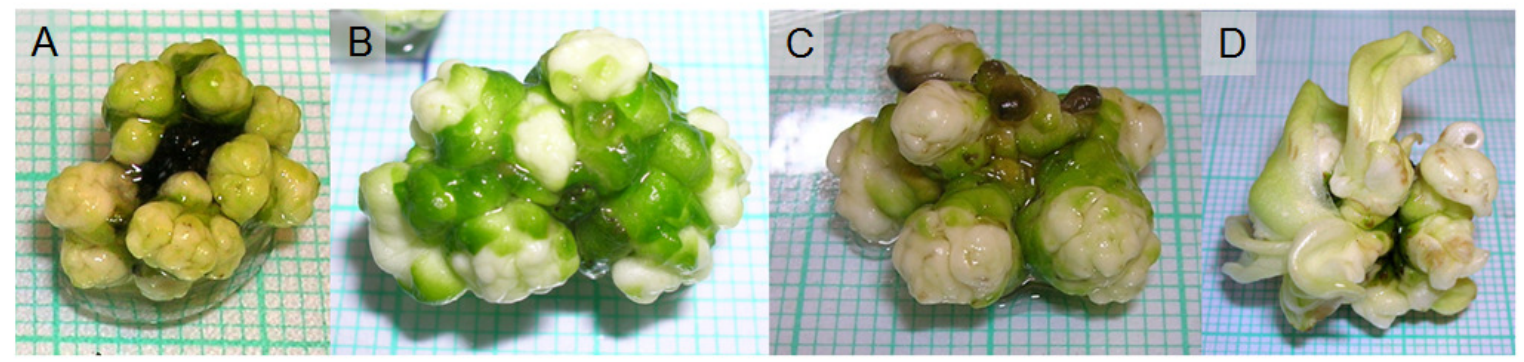

32. ábra. A folyadékkultúrás tenyésztés során az eltérő típusú citokininek hatása a GGb-telepek fejlődésére Spathiphyllum floribundum 'Petite' in vitro tenyészetében. (A) $0,2 \mathrm{mgL}^{-1}$ BA-tartalmú táptalaj hatására fejlődött apróbb GGb-k. (B) 0,2 $\mathrm{mgL}^{-1}$ BR-tartalmú táptalajon nevelt GGb-telep. (C) $0,2 \mathrm{mgL}^{-1}$ MT hatására nem a GGb-k száma, hanem méretük nőtt meg. (D) $0,2 \mathrm{mgL}^{-1}$ TDZ-tartalmú táptalajon egy 4-es állapotú (regenerálódásnak indult) GGb-telep, kissé hiperhidratált újonnan fejlödő levelekkel.

A 3-as (rügyszerü) állapotú GGb-kből mért peroxidázaktivitást (33. ábra) elemezve megállapítható, hogy a citokinintípusok szerinti csoportok között szignifikáns különbség tapasztalható. A legkisebb POD-aktivitást a BA-csoportnál mértem, ahol a legnagyobb volt a szaporodás mértéke, ugyanakkor nem volt teleppusztulás, és csak $9 \%$-nyi volt 2-es állapotú (pusztulásnak indult) telepek aránya. A jóval nagyobb mortalitással jellemezhető BR- és MTtáptalajoknál, ahol rendre $18 \%$ és $16 \%$ volt az 1-es és 2-es állapotú (elpusztult és pusztulásnak 
indult) GGb-k száma (26. ábra), a peroxidázaktivitás magasabb értékeket mutat. A TDZ-kezelés POD mintái müszaki problémák miatt megsemmisültek.

A GGb-szaporodás szempontjából, a vizsgált paraméterek alapján az alábbi rangsor állítható fel a citokinintípusok között, aktivitásukat tekintve: BA és TDZ >> MT >> BR.

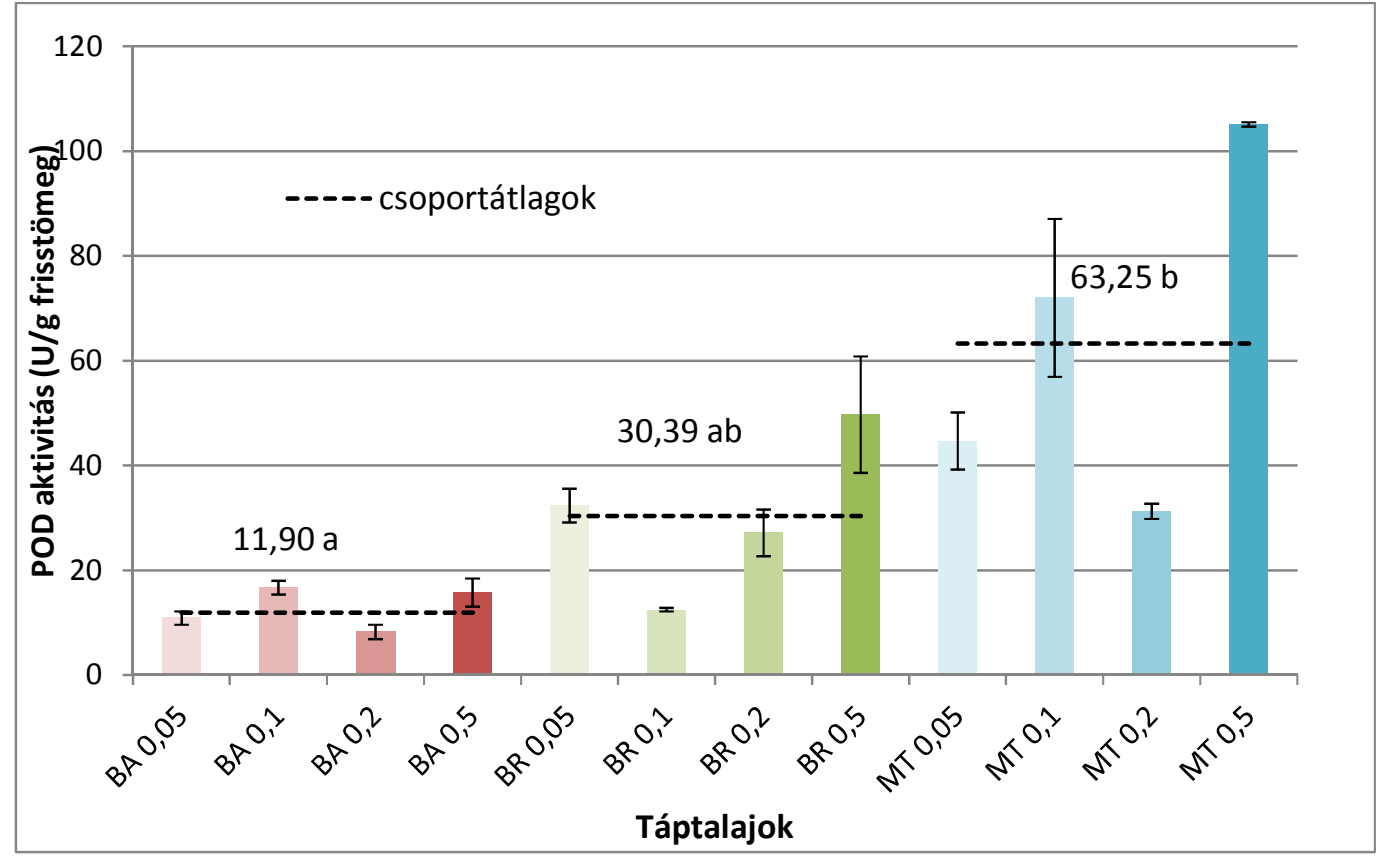

33. ábra. A peroxidázaktivitás a folyadékkultúrás tenyésztés során az eltérő típusú és koncentrációjú citokininek hatására Spathiphyllum floribundum 'Petite' in vitro GGb tenyészetében. Az eltérő betűk szignifikáns különbséget jelölnek, Tukey teszt, $\mathbf{p}<0,10$.

\subsubsection{Emelt makroelem- és szacharóz-koncentráció hatásának vizsgálata}

$\mathrm{Az}$ emelt makroelem- és szacharóz-koncentráció vizsgálata során szilárd táptalajokat alkalmaztam, melyek mindegyike ugyanazt a növekedésszabályozó koncentrációt tartalmazta $\left(0,5 \mathrm{mgL}^{-1}\right.$ BA és $\left.0,1 \mathrm{mgL}^{-1} \mathrm{NES}\right)$. A GGb-telepek a szacharózt is tartalmazó szilárd táptalajokon legalább 85 \%-os arányban maradtak meg a 3-as (rügyszerü) állapotban, 2-szeres makroelem koncentráció esetén pedig szinte a kezelést kapó összes GGb-telep ( 96 és 97 \%-uk) így viselkedett. A kontrollkezelésen kívül, mely nem kapott szacharózt, a többi esetben gyakorlatilag nem volt pusztulásnak indult telep, és egyetlen növény sem pusztult el. Ezzel szemben a kontrollkezelés mellett a GGb-telepek 41 \%-a pusztulásnak indult szacharóz hiányában. A GGb-regeneráció a nagy szacharózkoncentráció vagy nagy makroelem-koncentráció esetén gátlódik, míg egyszeres makroelemkoncentráció és $20 \mathrm{gL}^{-1}$ szacharóz használata esetén 14,3 \%-uk kezd el regenerálódni, csakúgy, mint a szacharózmentes táptalajon, de azzal szemben pusztulásnak induló telepek nem fordulnak elő (34. ábra). 


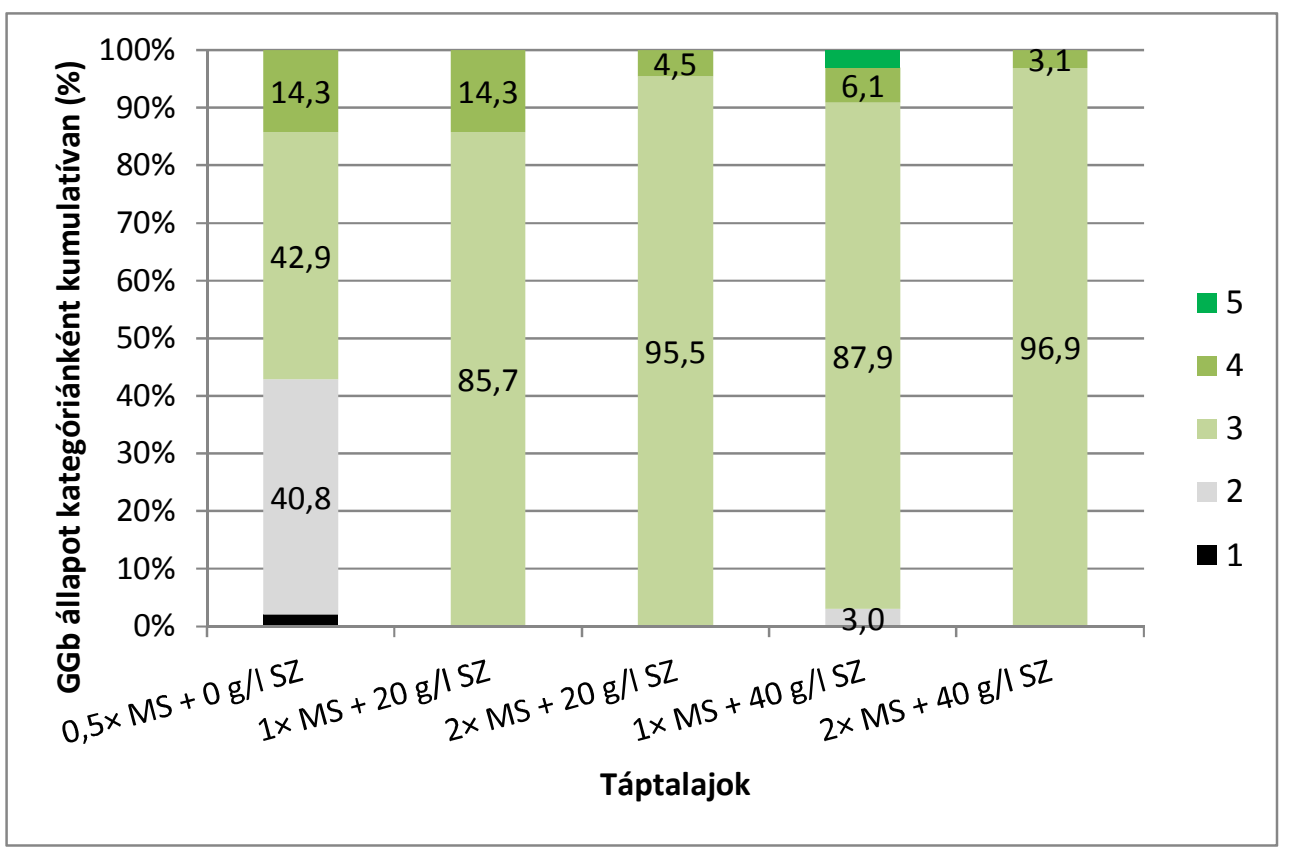

34. ábra. Az emelt makroelem és szacharózkoncentráció hatása a GGb-telepek fejlődési állapotára Spathiphyllum floribundum 'Petite' in vitro tenyészetében. $(1$ - elpusztult telepek, 2 - pusztulásnak indult, barnuló részeket legalább fele arányban tartalmazó telepek, 3 - egészséges, fejlődő, zöld vagy zöldes árnyalatú telepek, 4 - a sarjregeneráció megindulásának jeleit mutató telepek, 5 - teljesen sarjjá regenerálódott részeket tartalmazó telepek).

A 35. ábra a kezelések hatására kialakuló telepátmérőket és a telepen belüli GGb számot mutatja. A kezelések nem okoznak szignifikáns különbséget a GGb telepeken belül a GGb-k darabszámában, ellenben a telepátmérő a kontroll táptalaj esetén jelentősen nagyobb, mint a többi kezelés hatására, de azok között már nincs különbség. Ugyanezt a tendenciát követik a 36. ábraról leolvasható teleptömeg és a fajlagos GGb-tömeg értékek. A kontrollkezelésnél kialakuló nagyobb telepátmérö tehát nagyobb teleptömeget is okoz. Ennek jórészt a telepek által felvett többletvíz lehet az oka, ami a 37. ábran lévő szárazanyag-tartalom értékekből is világosan látszik: a kontrollkezelés esetén a szárazanyag \% nagyjából a fele, a többi kezelés esetén mért értékeknek. A makroelem és a szacharózkoncentráció emelkedésével a szárazanyag \% is nő, bár a statisztikai próbák szignifikanciát nem mutattak ki az alacsony mintaelemszám miatt. 


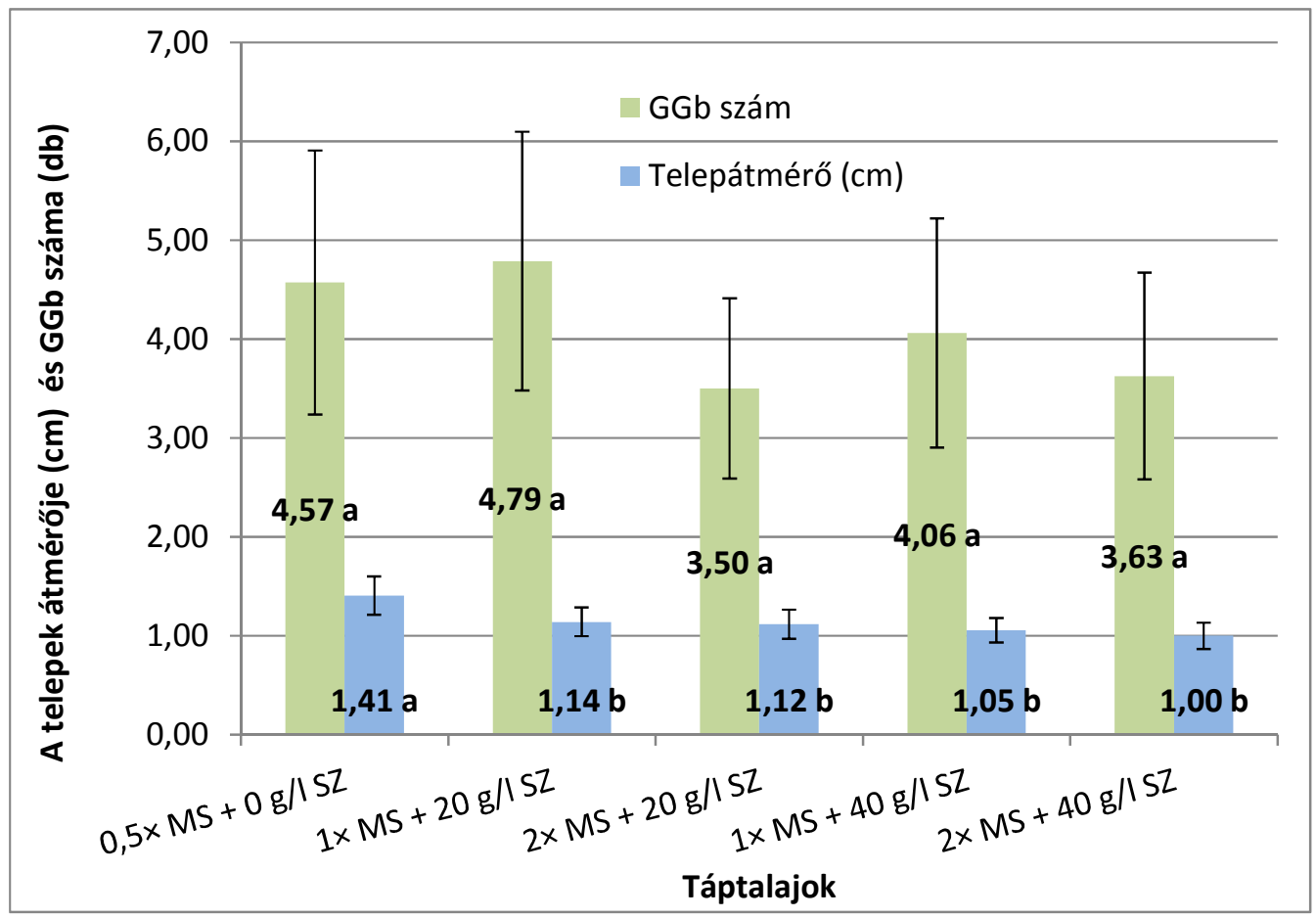

35. ábra. Az emelt makroelem- és szacharózkoncentráció hatása a GGb-telepek átmérőjének és a telepen belüli GGb-darabszám alakulására Spathiphyllum floribundum 'Petite' in vitro tenyészetében. Az eltérö betük szignifikáns különbséget jelölnek, Games-Howell teszt, p<0,05.

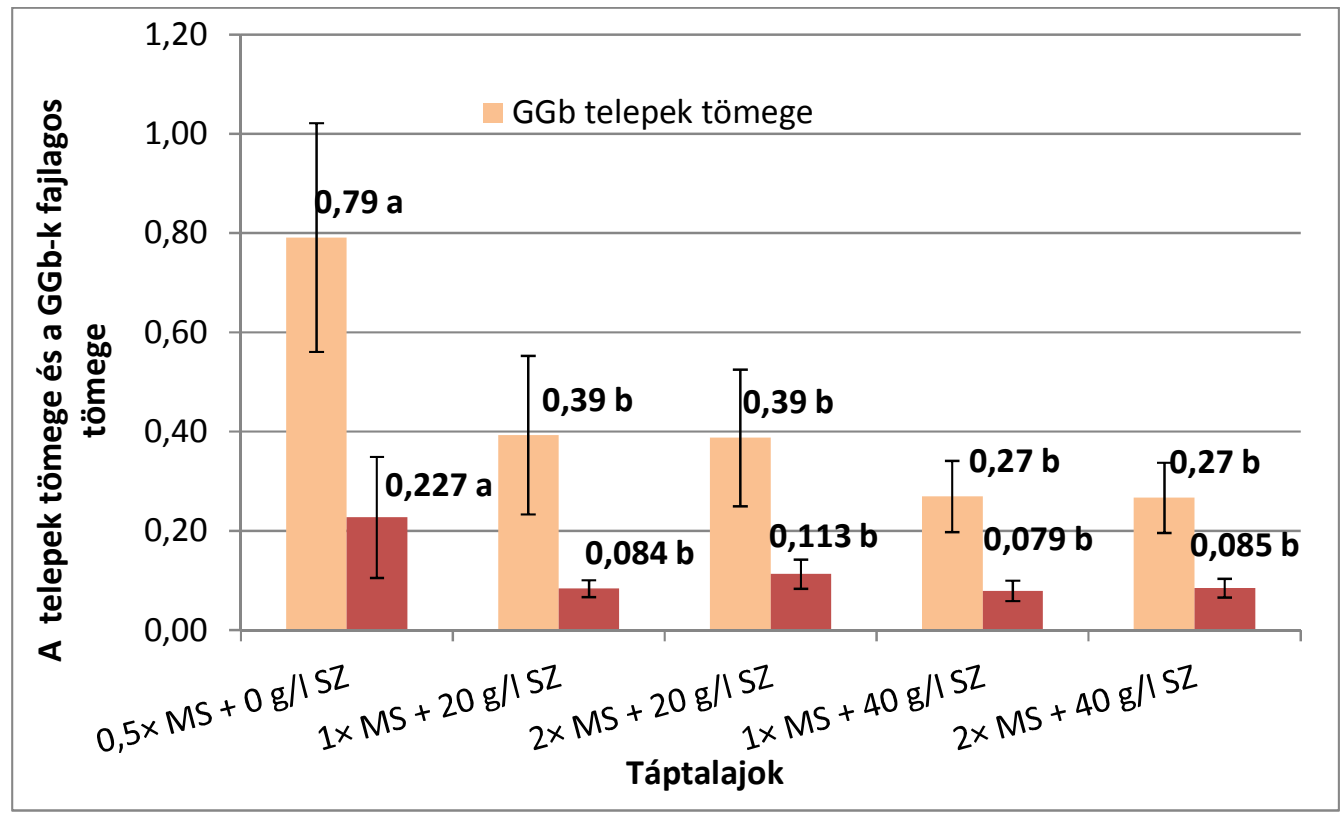

36. ábra. Az emelt makroelem- és szacharózkoncentráció hatása a GGb-telepek tömegére és az egyes GGb-k fajlagos tömegére Spathiphyllum floribundum 'Petite' in vitro tenyészetében. Az eltérő betük szignifikáns különbséget jelölnek, Games-Howell teszt, $\mathbf{p}<0,05$. 


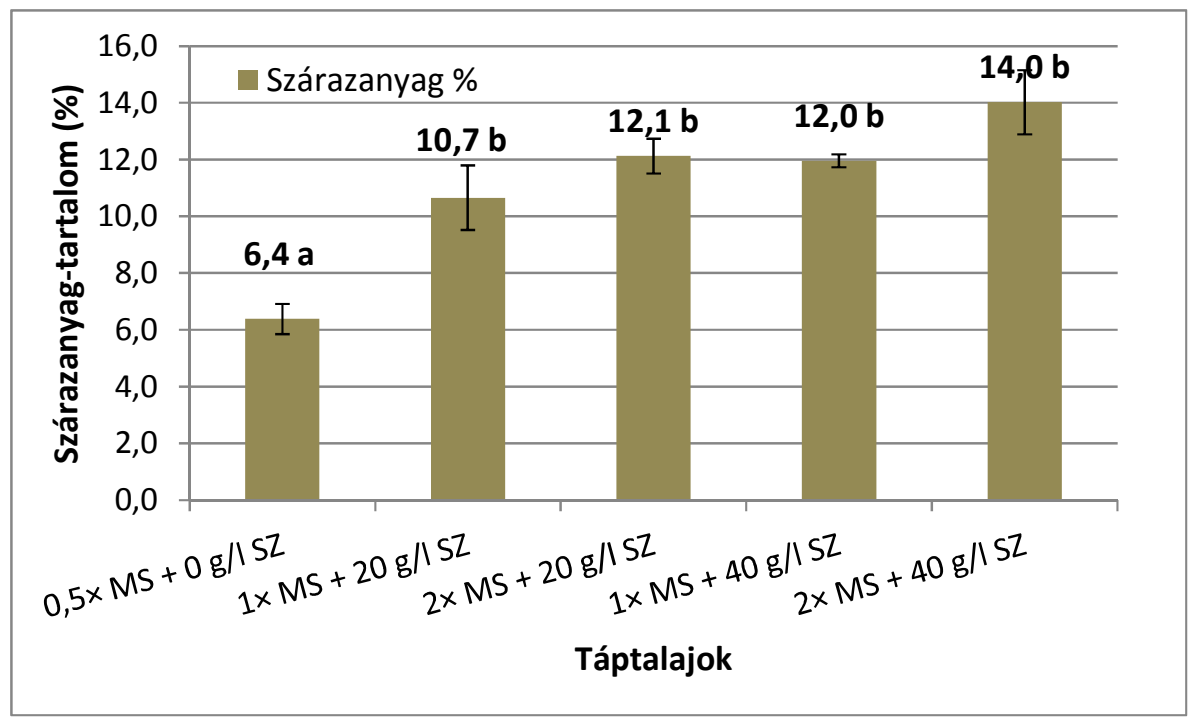

37. ábra. Az emelt makroelem- és szacharózkoncentráció hatása a GGb-telepek szárazanyag-tartalmára Spathiphyllum floribundum 'Petite' in vitro tenyészetében. Az eltérö betúk szignifikáns különbséget jelölnek, Games-Howell teszt, $\mathbf{p}<0,05$.

A GGb-telepek alakindexét, vagyis a formáját meghatározó leírószám alakulását szemlélteti a mellékletben a 77. ábra. Az alakindexet a GGb-telepek két vízszintes síkú átmérőjéből számoltam az $|\mathrm{x}-\mathrm{y}| / \max \{\mathrm{x}, \mathrm{y}\}$ képlettel (ahol x és y a két átmérő), vagyis minél jobban közelít az értéke a 0-hoz, annál inkább kör alakú a vízszintes keresztmetszete a telepnek, és minél inkább megnyúltabb egyik irányban a telep, az index értéke annál inkább tart az 1-hez. Az alakindex nem mutatott eltérést a különféle kezelések hatására, tehát a telep növekedési jellegét ezek a paraméterek nem befolyásolják. Minden esetben 0,2 körül alakult az alakindex, ez azt jelenti, hogy átlagosan $20 \%$ az eltérés a GGb-telep két vízszintes átméröje között.

A GGb-telepek klorofilltartalmát vizsgálva megállapítható, hogy a makroelemkoncentráció növelésével nő a klorofilltartalom $20 \mathrm{gL}^{-1}$ szacharózkiegészítés mellett, ám 40 gL használata már kisebb klorofillkoncentrációt eredményez, és nem jelentkezik a makroelemtöbbletből származó előny. A $20 \mathrm{gL}^{-1}$ szacharóz még nincs gátló hatással a klorofillkoncentrációra, de a többlet már igen, gátolja a klorofillképződést (38. ábra). 


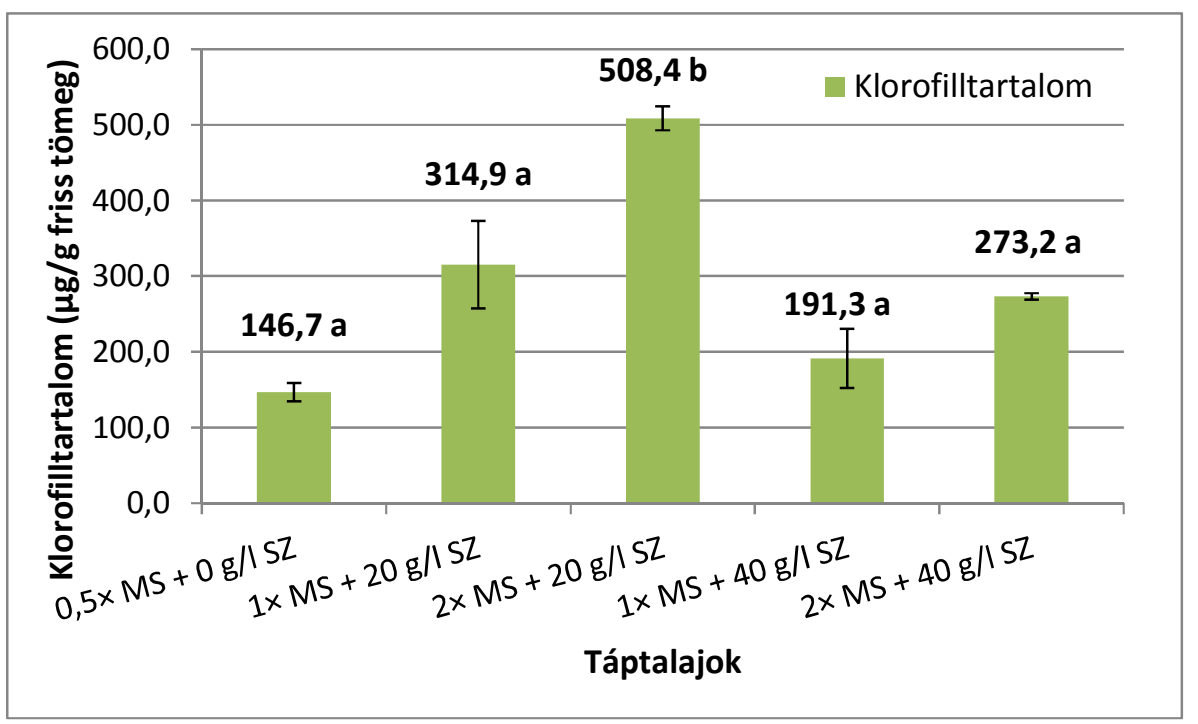

38. ábra. Az emelt makroelem- és szacharózkoncentráció hatása a GGb-telepek klorofilltartalmára Spathiphyllum floribundum 'Petite' in vitro tenyészetében. $\mathrm{Az}$ eltérö betük szignifikáns különbséget jelölnek, Games-Howell teszt, $\mathbf{p}<\mathbf{0 , 0 5}$.

A GGb telepek peroxidázaktivitása (39. ábra) emelkedő tendenciát mutat a táptalaj becsült ozmolalitás értékével $\left(\psi_{\text {szum }}=\psi_{\text {só }}+\psi_{\text {szacharóz }}+\psi_{\text {agar }}\right)$ összhangban, a lineáris korrelációs koefficiens értékét csak tájékoztatásul adom meg, mert az alacsony mintaelemszám nem validálja teljesen az összefüggést $\left(\mathrm{R}^{2}=0,77\right)$. Tehát minél több a táptalaj oldott szárazanyagtartalma (EC-je), a POD-aktivitás annál magasabb a GGb-telepekben az abiotikus stressz következtében.

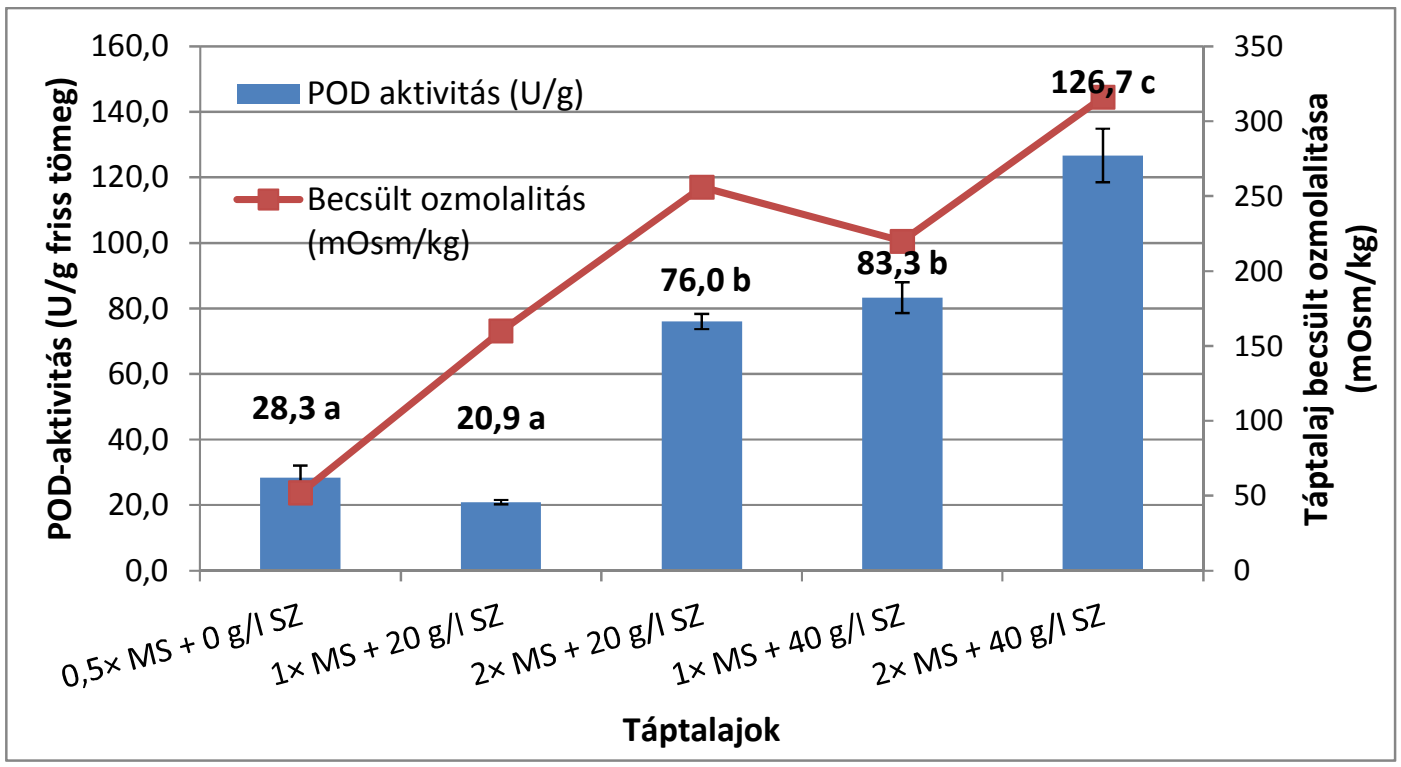

39. ábra. Az emelt makroelem- és szacharózkoncentráció hatása a GGb-telepek peroxidázaktivitására Spathiphyllum floribundum 'Petite' in vitro tenyészetében. Az eltérő betük szignifikáns különbséget jelölnek, Games-Howell teszt, $\mathbf{p}<0,05$. 


\subsubsection{Triazol típusú növekedési retardánsok hatásának vizsgálata}

A triazol típusú növekedési retardánsok hatásának vizsgálata egy kísérleten kívüli megfigyelés miatt merült fel. A pihentető, alacsony citokininkoncentrációjú táptalajon $(0,1 \mathrm{mgL}$ $1 \mathrm{KIN}, 0,2$ és $0,4 \mathrm{mgL}^{-1}$ BA) lévő GGb-telepek és $3 \mathrm{mgL}^{-1} \mathrm{GA}_{3}$ mellett nevelt telepek kis számban (12+12 telep) egyszerre kerültek át $0,5 \mathrm{mgL}^{-1}$ PBZ-t és $0,2 \mathrm{mgL}^{-1}$ BA-t tartalmazó táptalajra 2011 novemberében. Hozzávetőleg 6 hónap múlva, 2012 májusában a kis citokininkoncentrációjú táptalajról származó telepek mindegyikén elindult, és sok esetben már le is zajlott a sarjregeneráció, míg a gibberellinsavat tartalmazó táptalajokról származó telepek esetén egyiknél se, mindegyik megmaradt a 3-as, rügyszerü állapotban. A megfigyelés igazolására a triazolokkal tervszerü kísérleteket is folytattam.

\subsubsection{Paklobutrazol hatása a GGb-tenyészetekre}

Az előkísérletnek tekinthető $0,5 \mathrm{mgL}^{-1}$ PBZ-t és $0,2 \mathrm{mgL}^{-1}$ BA-t tartalmazó táptalajon regenerálódó telepekben a regenerálódó GGb-k nagy száma miatt (12 telep, telepenként legalább 5-6 GGb) a regeneráció folyamata megfigyelhetővé vált, egyszerre jelen voltak a regeneráció eltérő stádiumában lévő alakok. Ezeket megvizsgálva fázisokra bontottam a folyamatot (40. ábra):

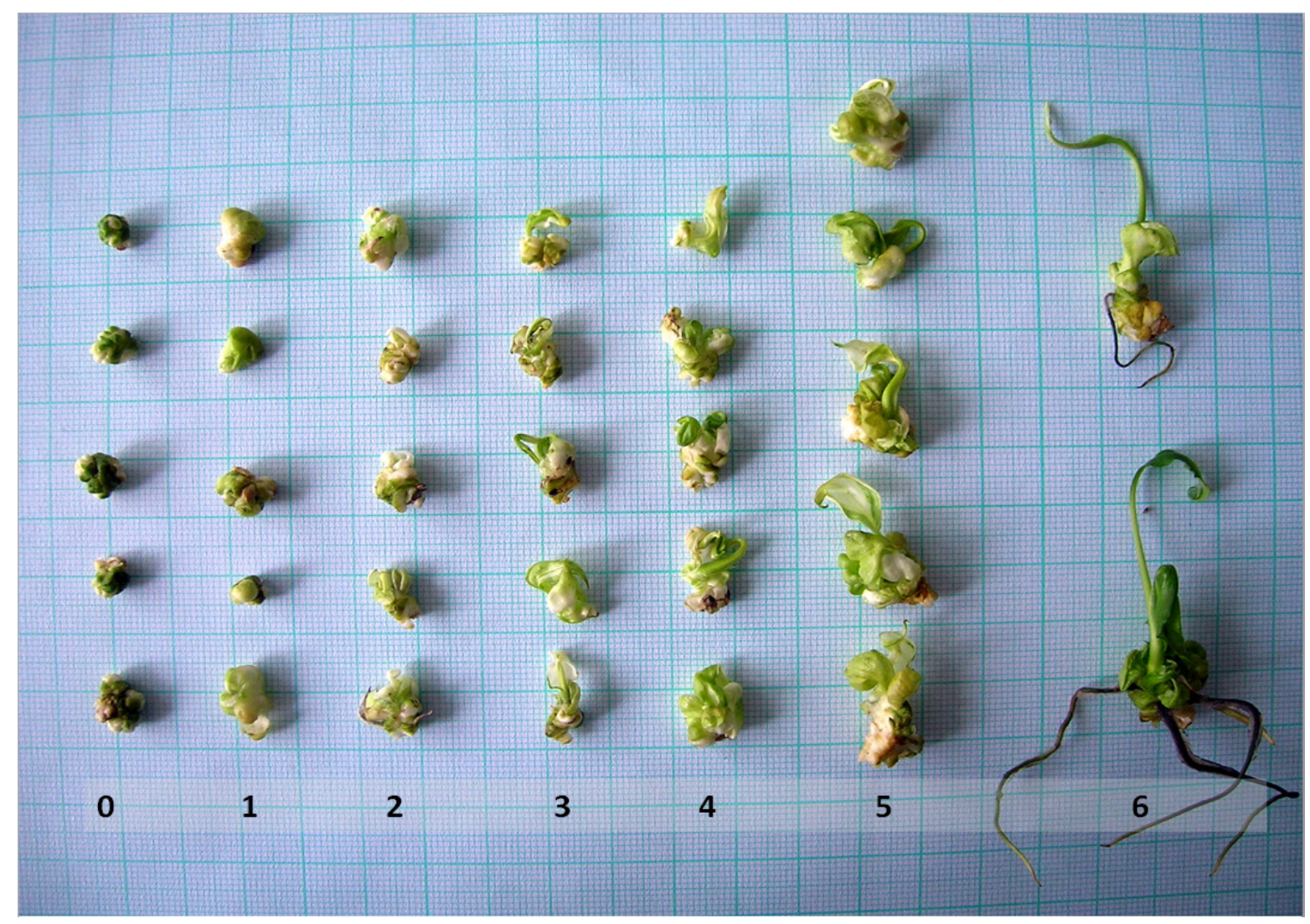

40. ábra. A GGb-k regenerációjának fázisai Spathiphyllum floribundum 'Petite' in vitro tenyészetében. 
Az egyes fázisokra jellemző morfológiai állapotleírásokat az alábbi felsorolás szerint lehet összefoglalni.

0. A GGb rügyszerü, a teteje fehér, oldalt a levélkezdemények zöldek, ez a regenerációt megelőző állapot, megfelel a korábbi 3-as állapotkategóriának. A következő 1-6. fázisok pedig a korábbi 4-esként meghatározott állapotkategória alfázisainak tekintendők.

1. Az oldalsó zöld levelek nagyobbak, fejeskáposztaszerüen borítják a felső fehér részt is.

2. A csúcs kinyílik, a fehér részből fehér levélkezdemények emelkednek ki.

3. A legfelső, fehér levélkezdemény zöldülni kezd.

4. A levélkezdemény még jobban elkezd kiemelkedni a GGb közepéből, az új levél kipödrődik.

5. Láthatóvá válik a levél alakja, de a levélnyél még rövid.

6. A levélnyél megnyúlik, és egyúttal láthatóvá válik a hajtástengely is.

A gyökérképződés a 6 . fázisban szinte mindig bekövetkezik, korábban ugyan nem jellemző, de előfordulhat. Biokémiai vizsgálatok során úgy találtam, hogy a peroxidázaktivitás mértéke jól jellemzi az egyes fázisokban lévő telepeket (41. ábra).

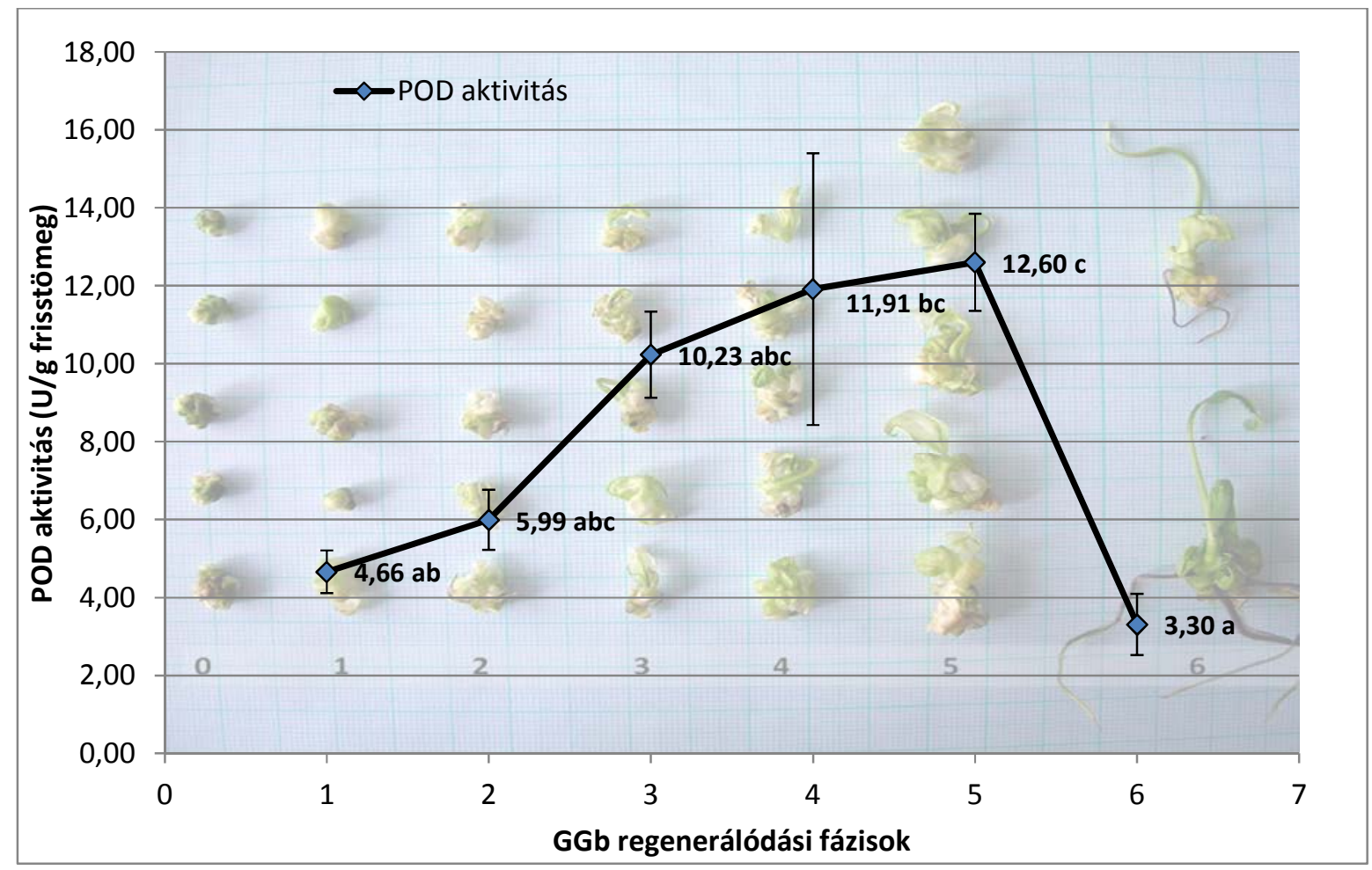

41. ábra. A POD-aktivitás értékei a GGb regenerálódási fázisokban Spathiphyllum floribundum 'Petite' in vitro tenyészetében. Tukey-Kramer teszt, $\mathbf{p}<0,05$. 
A POD-aktivitás a regeneráció előrehaladásával nő, majd a sarjjá alakulást követően hirtelen lecsökken. A PBZ hatására a GGb-telepek kisebb POD-aktivitással rendelkeznek, mint a PBZ-mentes táptalajokon (lásd 32. ábra, 39. ábra).

Az előkísérlet után a paklobutrazol GGb-kre alkalmazható koncentrációinak tesztelését egyéb növekedésszabályozószerek használata nélkül végeztem, $1 / 2 \mathrm{MS}$ táptalajon, $20 \mathrm{gL}^{-1}$ szacharóz jelenléte mellett. A megvizsgált koncentrációk az alábbiak voltak: 0,$25 ; 0,5 ; 1$; $2 \mathrm{mgL}^{-1}$. Már a táptalajra helyezés után 10 nappal a legmagasabb, $2 \mathrm{mgL}^{-1}$ PBZ-koncentráció mellett a GGb-telepek barnulni kezdtek, és lassan elhaltak. A kísérlet indítása után 8 héttel felmértem az állapotukat, ekkor még volt a $2 \mathrm{mgL}^{-1}$ PBZ kiegészítésű táptalajon élő GGb (42. ábra), 12 héttel az indítás után már mind elpusztult (43. ábra). A $2 \mathrm{mgL}^{-1}$ PBZ-koncentráció toxikus a GGb-k számára.

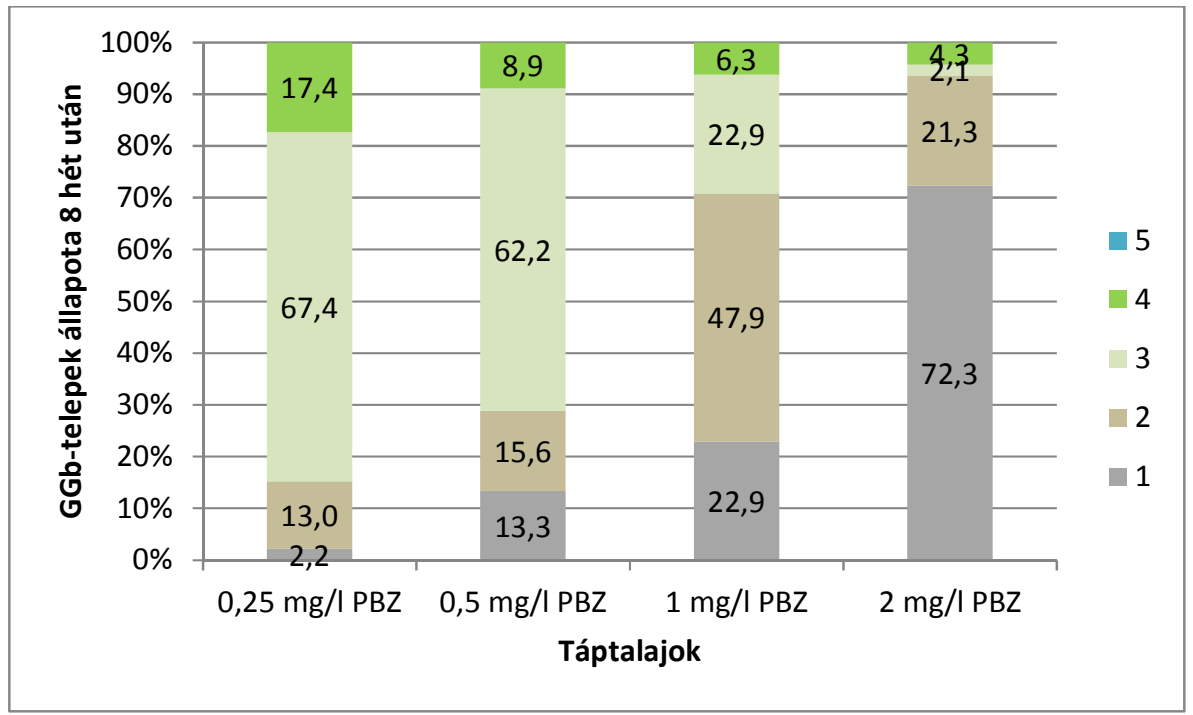

42. ábra. A PBZ-koncentráció hatása a GGb-telepek állapotára 8 héttel a táptalajra helyezés után Spathiphyllum floribundum 'Petite' in vitro tenyészetében.

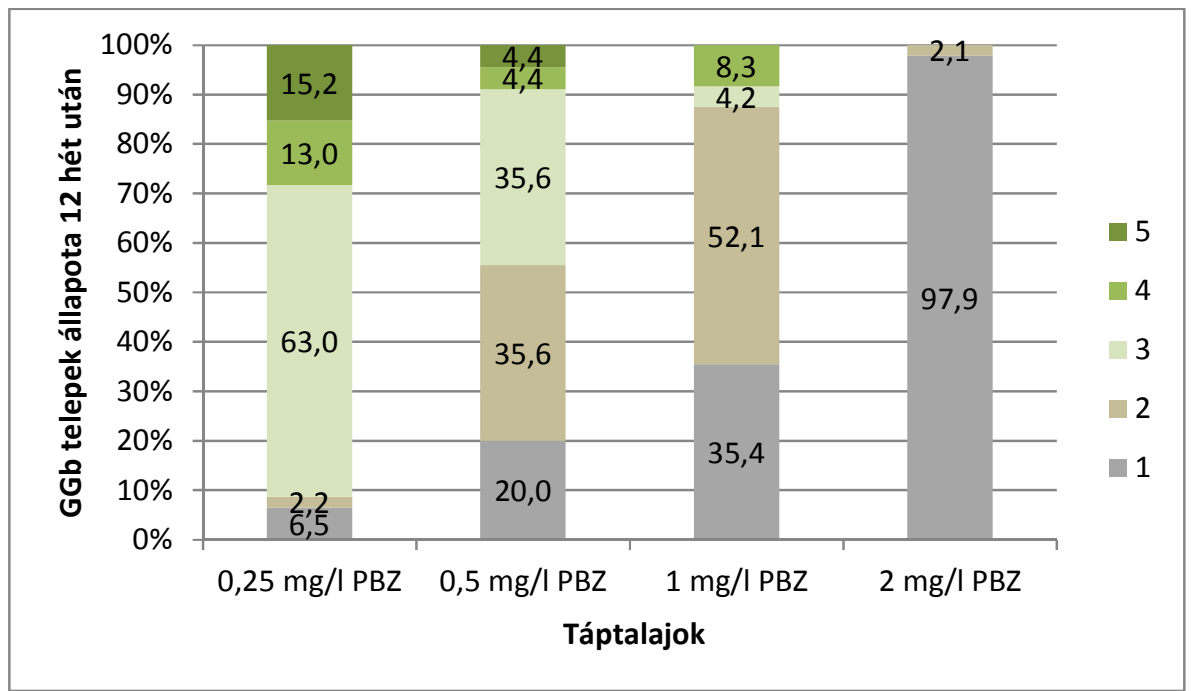

43. ábra. A PBZ-koncentráció hatása a GGb-telepek állapotára 12 héttel a táptalajra helyezés után Spathiphyllum floribundum 'Petite' in vitro tenyészetében. 
A pusztulásnak indult GGb-telepek száma növekedést mutat a PBZ koncentrációjának növekedésével. A vizsgált koncentrációk közül a legkisebb, 0,25 $\mathrm{mgL}^{-1} \mathrm{PBZ}$ okozta a legkisebb mortalitást és ennek hatására volt a legtöbb, 28 \%-nyi a regenerációt mutató telepek aránya (13\% elkezdett, $15,2 \%$ regenerálódott is már a 12. hét végére). Az előkísérlet során, a $0,5 \mathrm{mgL}^{-1}$ PBZ-t kiegészítettem 0,2 mgL ${ }^{-1}$ BA-nel, ekkor nem tapasztaltam jelentősebb mortalitást. A 12. hét után a POD-aktivitást megvizsgáltam a csoportok között, a 0,25 $\mathrm{mgL}^{-1}$ PBZ kezelésnél 32,5 $\mathrm{U} / \mathrm{mg}$, a $0,5 \mathrm{mgL}^{-1} \mathrm{PBZ}$ kezelésnél 47,3 U/mg, az $1 \mathrm{mgL}^{-1} \mathrm{PBZ}$ esetén pedig 50,7 U/mg átlagos értéket mértem. A tendencia növekvő, de statisztikai különbséget nem tudtam kimutatni az értékek között (n=3). Az összes regenerálódni kezdő GGb esetén találtam gyökérfejlődést (44. ábra), már a regeneráció első fázisai során is, szemben az előkísérlettel, ahol a $0,5 \mathrm{mgL}^{-1} \mathrm{PBZ}$ mellett citokinin is jelen volt $\left(0,2 \mathrm{mgL}^{-1} \mathrm{BA}\right)$, itt csak a regeneráció végénél alakultak ki gyökerek.

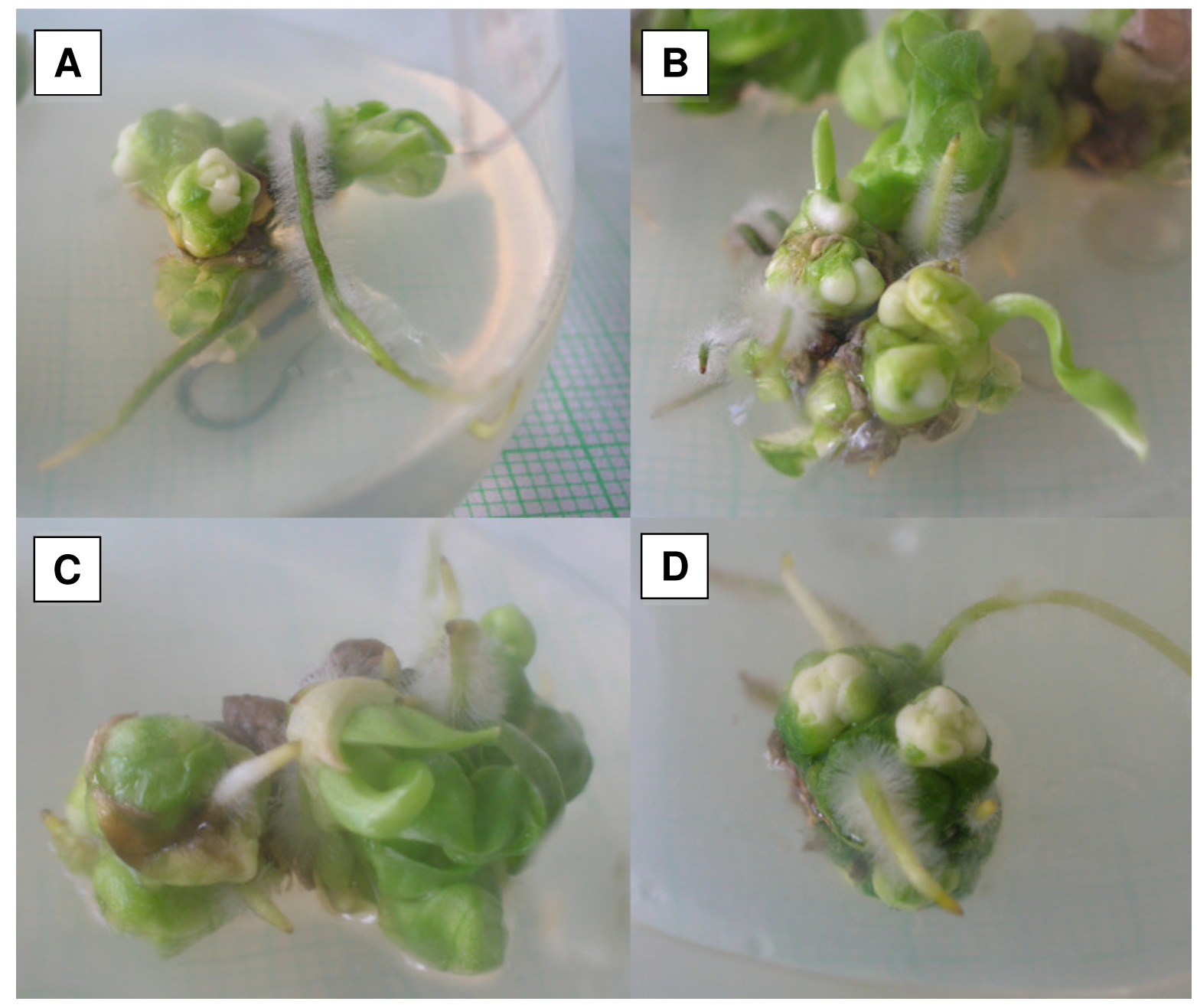

44. ábra. A regenerálódás kezdeti szakaszán lévő GGb-k, melyek már gyökeret is fejlesztenek PBZ hatására

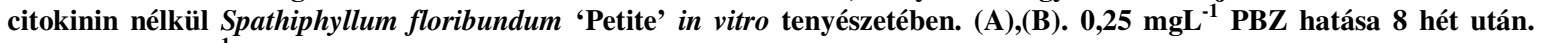
(C),(D). 0,5 $\mathrm{mgL}^{-1}$ PBZ hatása 8 hét után. 


\subsubsection{Flurprimidol hatása a GGb tenyészetekre}

A flurprimidol koncentrációkat a PBZ koncentrációkísérlet alapján kisebb tartományban választottam meg, és a táptalajokba növekedésszabályozóként még a FP mellett $0,2 \mathrm{mgL}^{-1} \mathrm{BA}$ és $0,1 \mathrm{mgL}^{-1} \mathrm{NES}$ is került. A tenyészeteket a kísérlet indítása utáni 12. héten vizsgálva megállapítottam, hogy mindegyik vizsgált FP-koncentráció mellett történt teleppusztulás, de legkisebb mértékü a $0,1 \mathrm{mgL}^{-1}$ koncentráció esetén volt. A regenerálódni kezdő telepek aránya ezen a koncentráción elérte a $26 \%$-ot, vagyis a telepek több mint negyede kezdte mutatni a sarjjá alakulás jeleit (45. ábra).

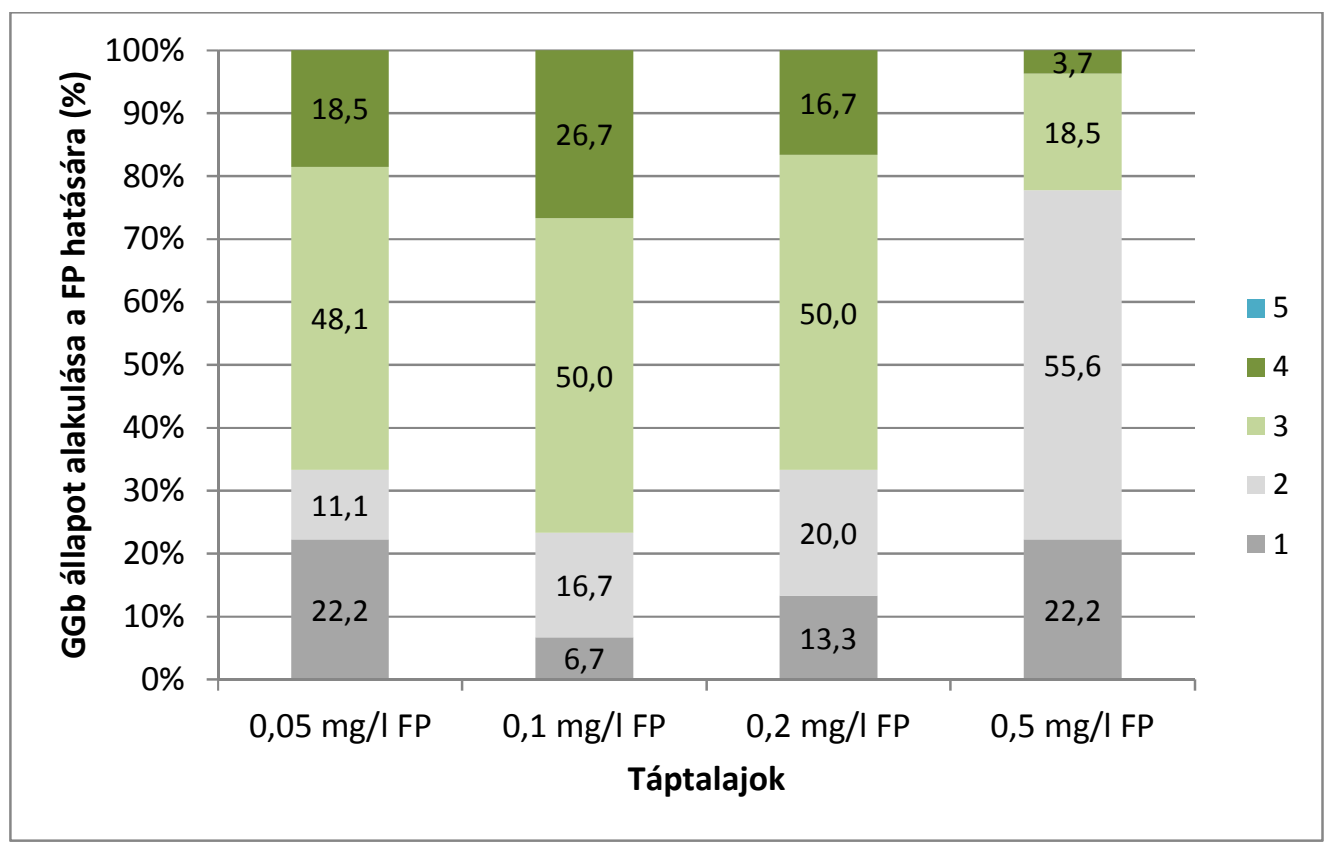

45. ábra. A FP-koncentráció hatása a GGb-telepek állapotára Spathiphyllum floribundum 'Petite' in vitro tenyészetében. (1 - elpusztult telepek, 2 - pusztulásnak indult, barnuló részeket legalább fele arányban tartalmazó telepek, 3 - egészséges, fejlődő, zöld vagy zöldes árnyalatú telepek, 4 - a sarjregeneráció megindulásának jeleit mutató telepek, 5 - teljesen sarjjá regenerálódott részeket tartalmazó telepek).

Sem a telepeken belüli GGb-számok alakulásában, sem a telepátmérőnél (melléklet 78. ábra) nem volt kimutatható különbség a FP-koncentrációk között. A GGb-szám átlagosan 8 körül alakult telepenként, ez 8 hétre vetítve nagyjából megfelel a folyadékkultúrás tenyésztés esetén tapasztalt szaporodási rátának, a többi szilárd táptalajon mérhetőhöz képest pedig magasabb.

A telepek alakindexében sem volt különbség a kezelések hatására, 0,16 és 0,20 között alakultak a 4 vizsgált koncentráció esetében. A teleptömegek némileg csökkenő tendenciát mutattak a FP-koncentráció emelkedésével, de statisztikailag ez nem volt igazolható (melléklet 79. ábra). Összehasonlítva ezeket a teleptömeg-értékeket a többi kísérletben kapottal, megállapítható, hogy nagyjából azonos eredményekről van szó, figyelembevéve, hogy ezek 12 hetes adatok, szemben a többi 8 hét után mért adattal. 


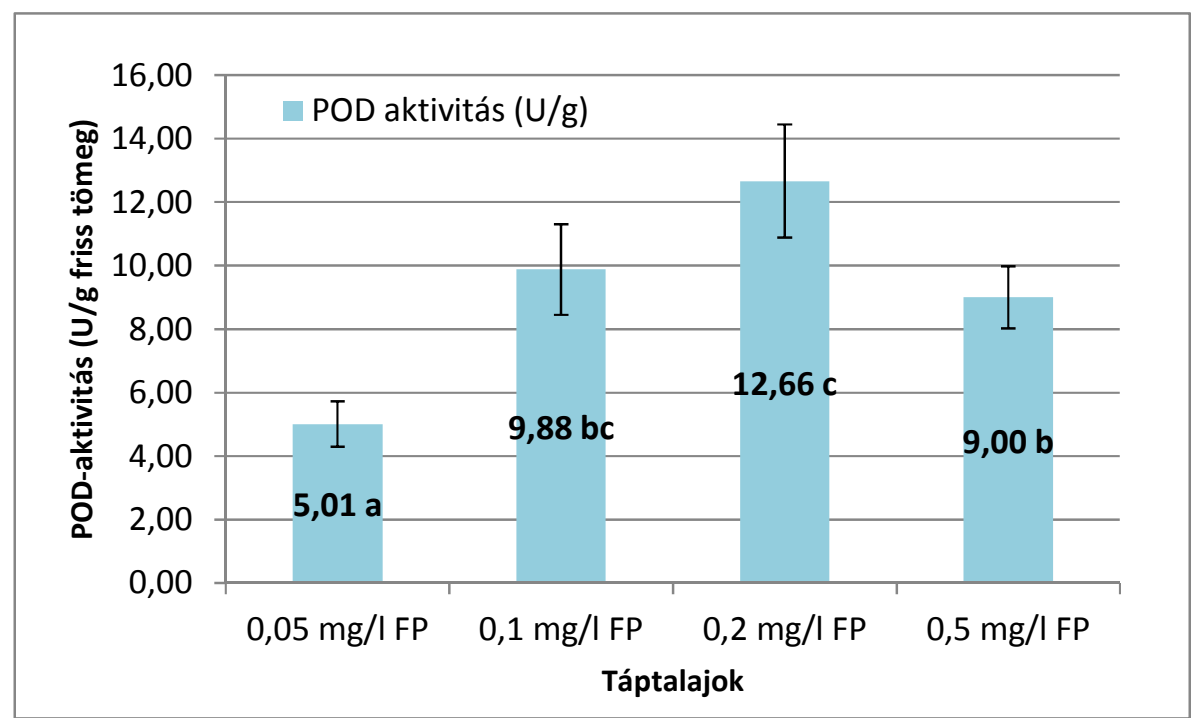

46. ábra. POD-aktivitás alakulása FP-kiegészítésü táptalajok hatására a GGb-telepekben Spathiphyllum
floribundum 'Petite' in vitro tenyészetében, Tukey-Kramer teszt, $\mathbf{p}<0,05$.

A POD-aktivitás értékeket vizsgálva látszik, hogy azon két koncentráció esetében a nagyobbak, ahol nagyobb volt a GGb-telepek regenerálódási aránya (46. ábra).

A flurprimidolos kezelések utóhatás-vizsgálatához az értékelés után a pusztulásnak nem indult (3-as és 4-es fázisú) GGb-telepeket $0,5 \mathrm{mgL}^{-1}$ BA-t és $0,1 \mathrm{mgL}^{-1} \mathrm{NES}$-at tartalmazó táptalajra helyeztem, majd 5 hónap elteltével értékeltem, hogy hány telepnél zajlott le a sarjregeneráció teljesen. Az 47. ábran látszik, hogy a 0,1 és $0,2 \mathrm{mgL}^{-1} \mathrm{FP}$-koncentrációjú kezelés utóhatására 5 hónap múlva az immár $0,5 \mathrm{mgL}^{-1} \mathrm{BA}$ táptalajon lévő GGb-tenyészeteknél a telepeknek több mint 50 \%-a alakult át sarjakká. Emellett a telepekben jelen voltak egyszerre itt is a regenerálódás egyéb fázisaiban lévő GGb-k, melyeket kategorizáltam és sorbarendeztem a regenerálódás fázisainak megfelelően, majd az egyes fázisokban itt is megmértem több minta átlagolásával a POD-aktivitást. Az egyes fázisok elkülönítése sokszor nehézségbe ütközött, és nem is minden kezelés esetén találtam mindegyik fázisba tartozó GGb-t, de a regeneráció folyamata jól nyomonkövethető így is (48-51. ábrák).

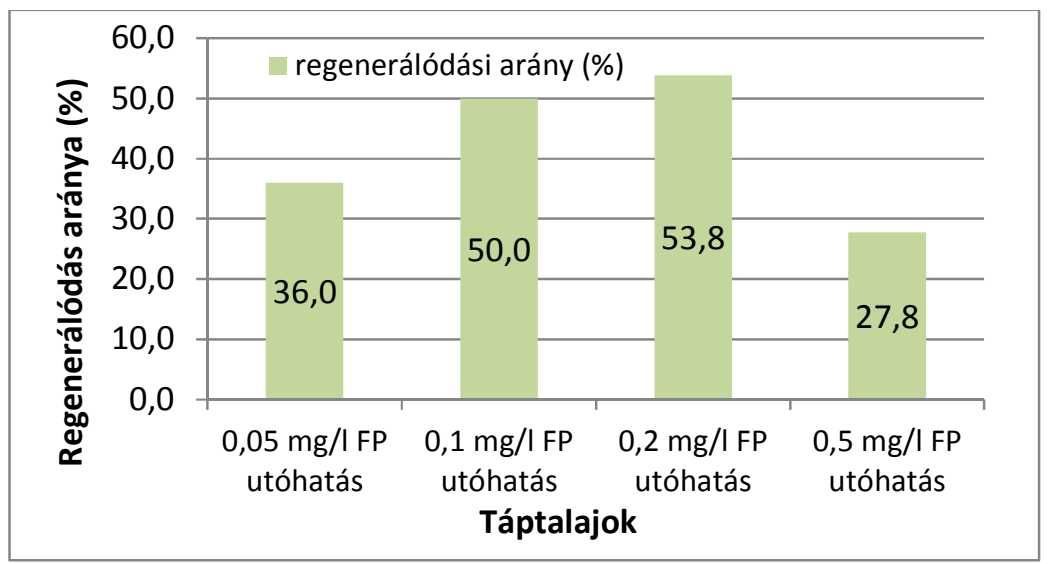

47. ábra. A FP-kezelések utóhatása során lezajlott sarjregeneráció aránya Spathiphyllum floribundum 'Petite' in vitro tenyészetében. 


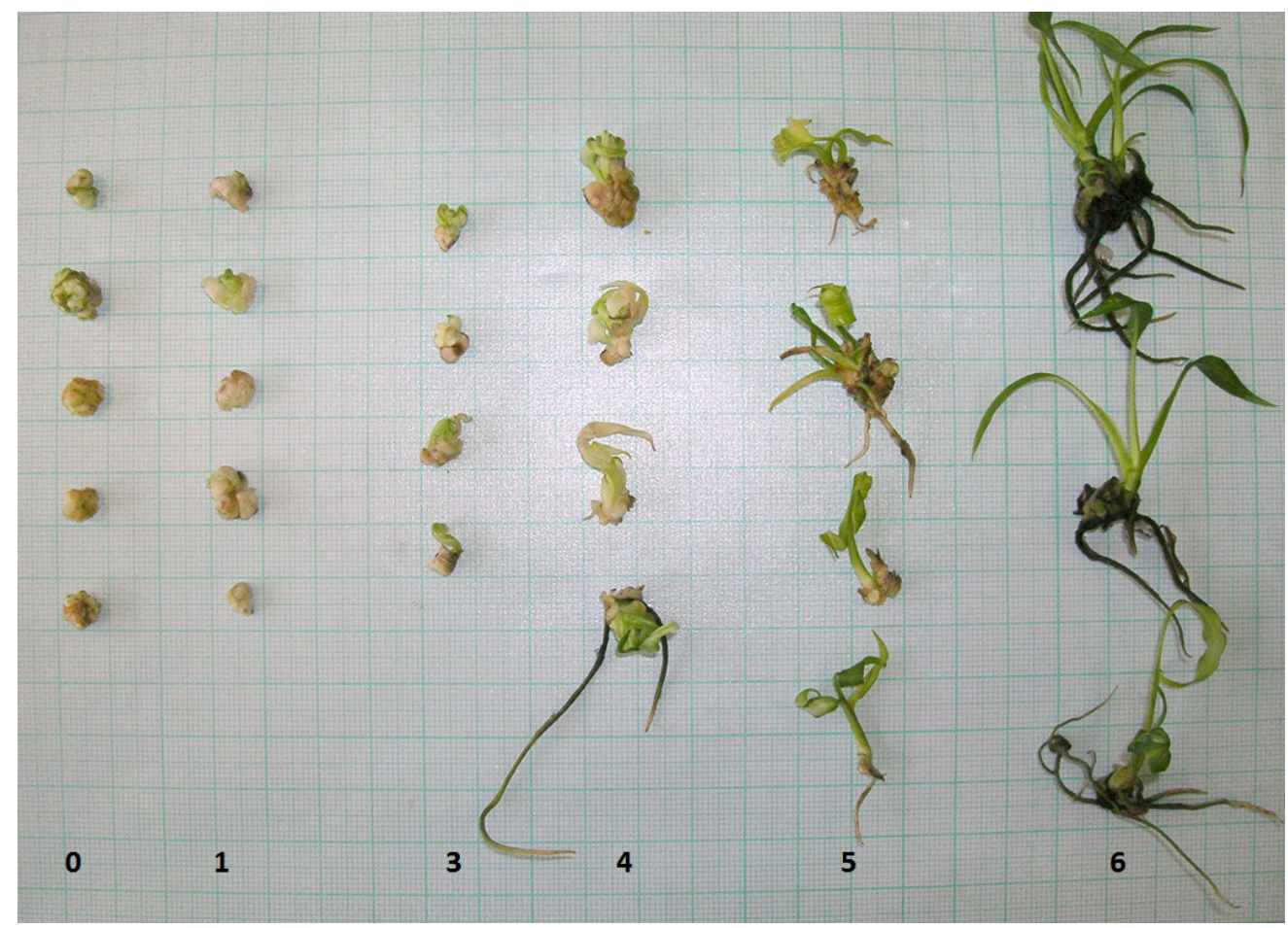

48. ábra. A $0,05 \mathrm{mgL}^{-1}$ FP táptalaj utóhatása során bekövetkező GGb-regeneráció Spathiphyllum floribundum 'Petite' in vitro tenyészetében.

Több esetben is szembeötlö, hogy a FP-kezelések utóhatására, hasonlóan a PBZ-hoz, a gyökeresedés a regeneráció korábbi fázisaiban is megjelenik, különösen a $0,5 \mathrm{mgL}^{-1}$ FP-kezelés után kifejezett a jelenség (51. ábra).

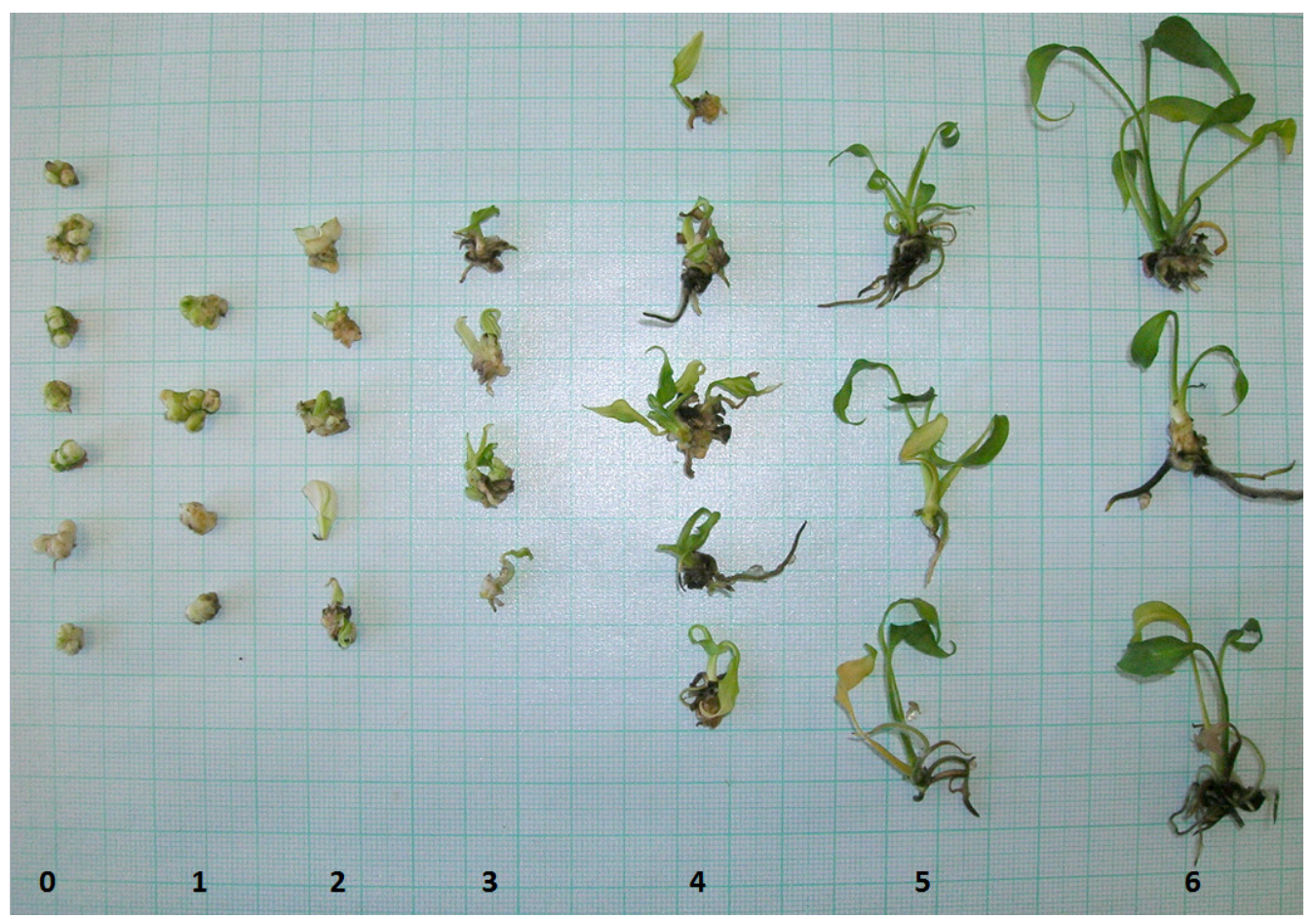

49. ábra. A 0,1 mgL ${ }^{-1}$ FP táptalaj utóhatása során a GGb-k regenerációja Spathiphyllum floribundum 'Petite' in vitro tenyészetében. 


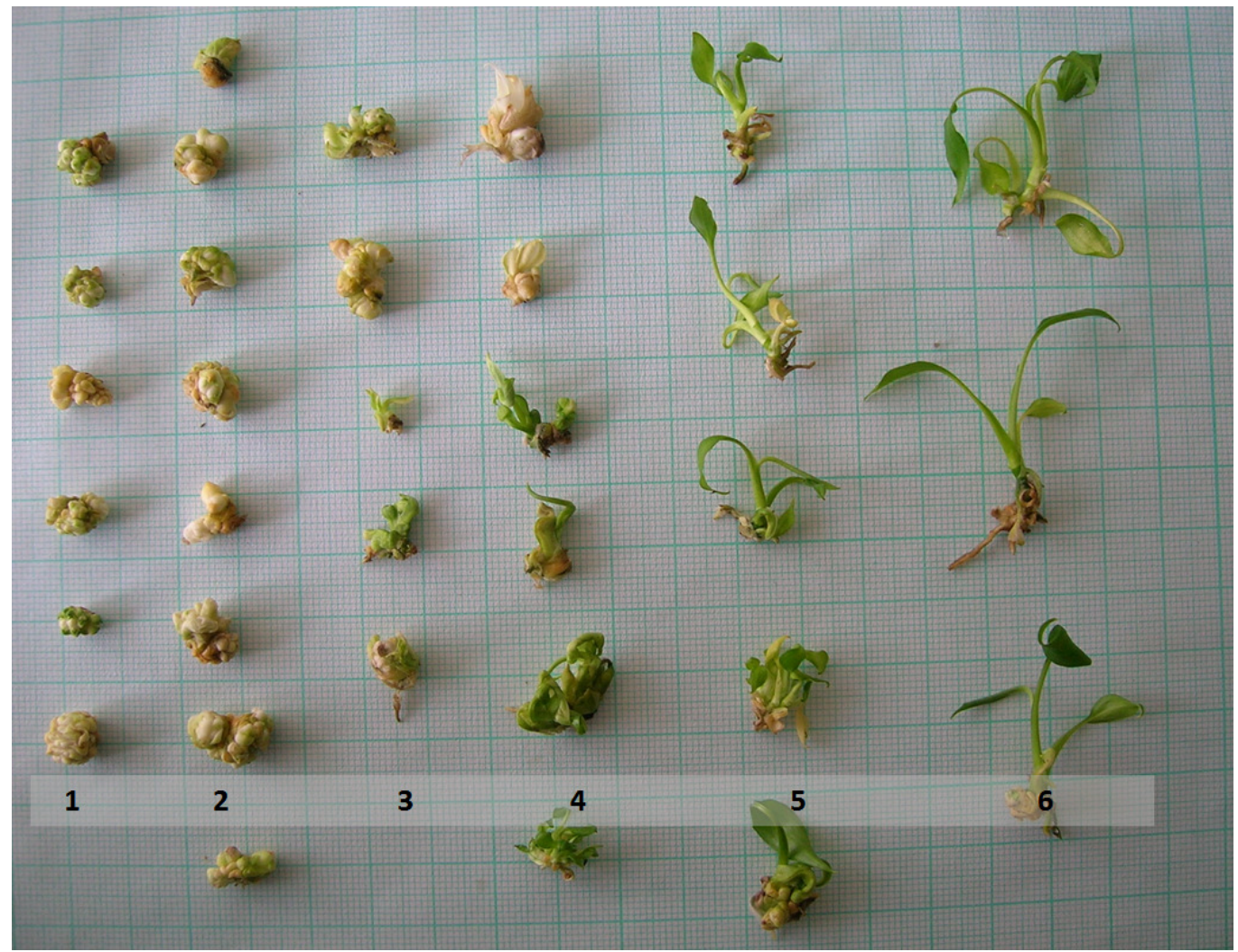

50. ábra. A 0,2 $\mathrm{mgL}^{-1}$ FP táptalaj utóhatása során a GGb-k regenerációja Spathiphyllum floribundum 'Petite' in vitro tenyészetében.

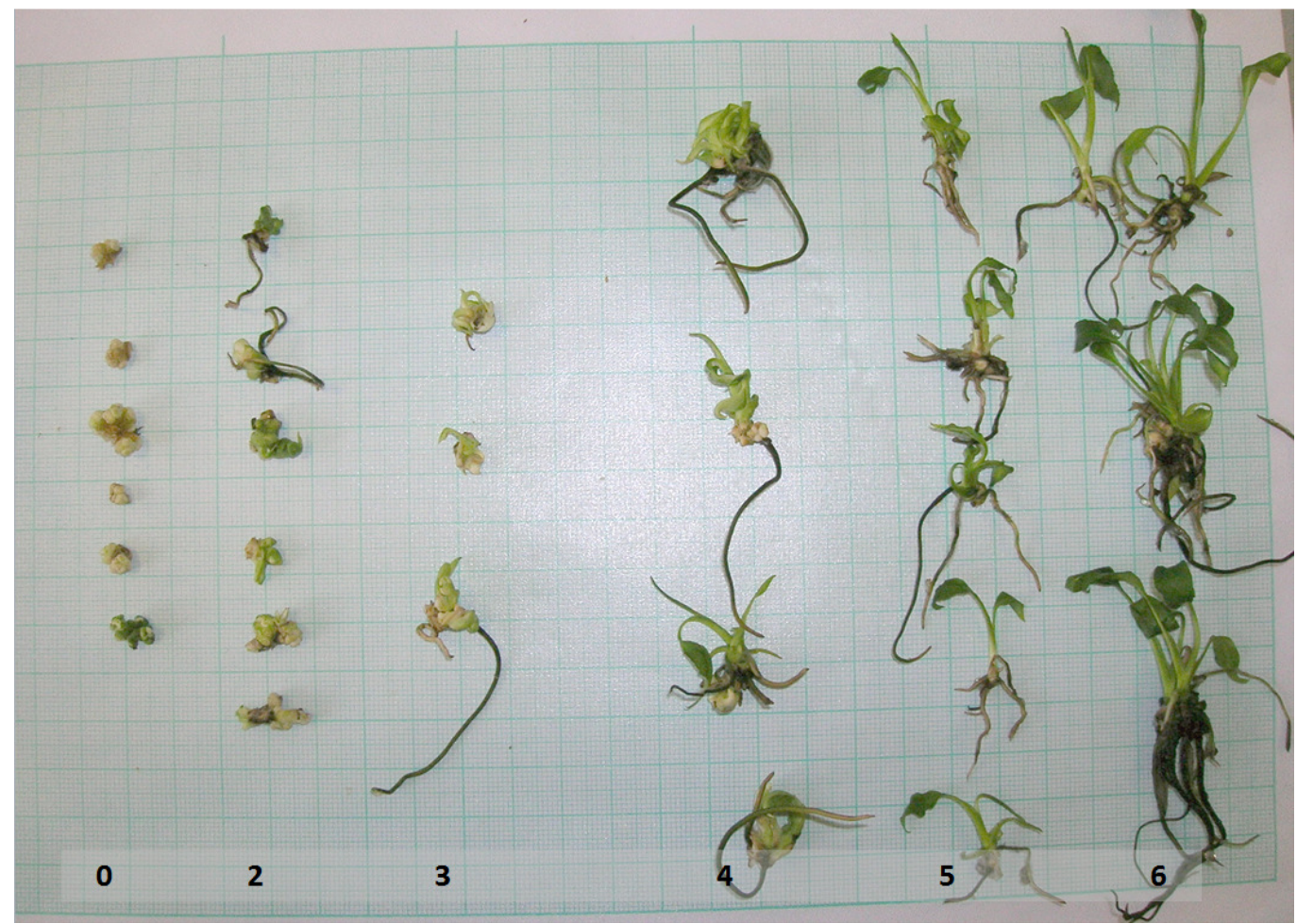

51. ábra. A 0,5 $\mathrm{mgL}^{-1}$ FP táptalaj utóhatása során a GGb-k regenerációja Spathiphyllum floribundum 'Petite' in vitro tenyészetében. 


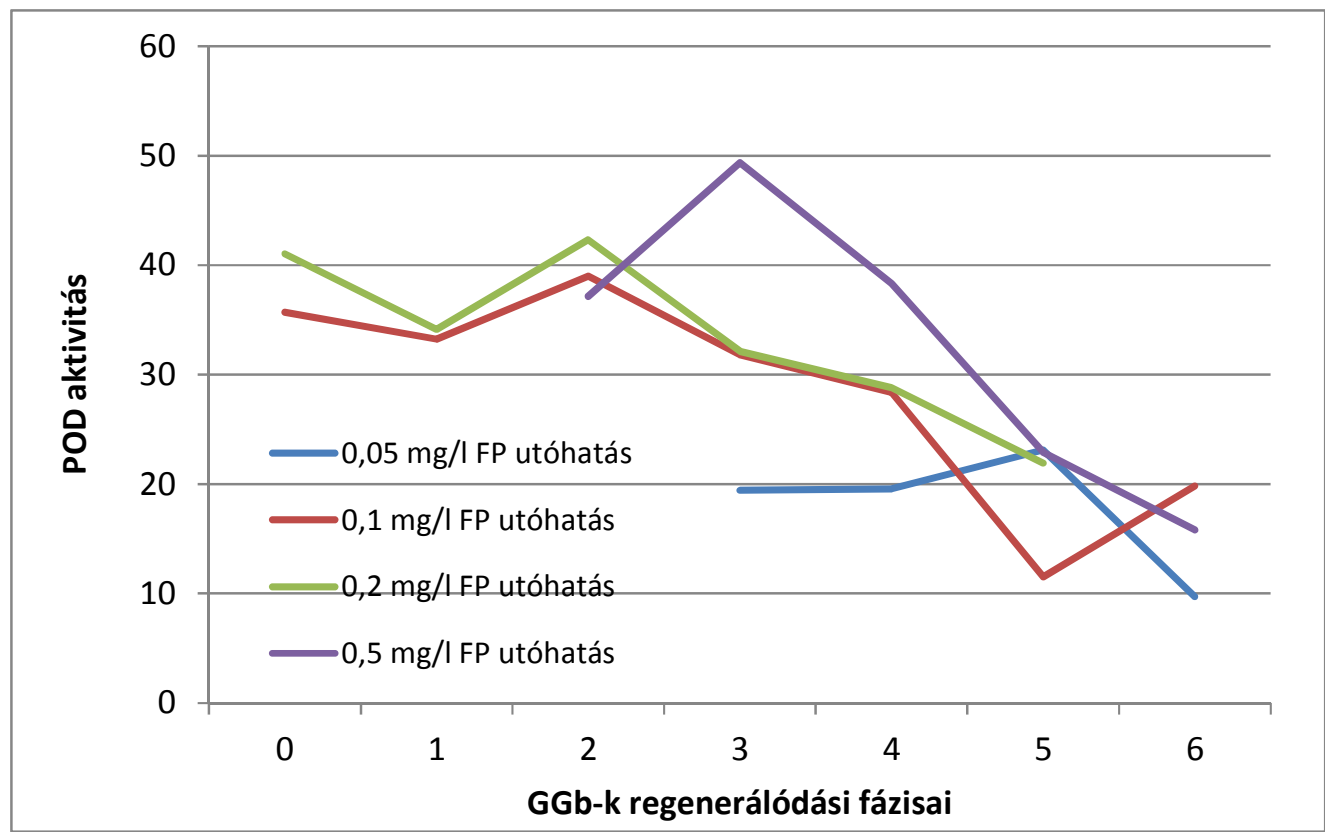

52. ábra. A FP-kezelések utóhatása során a különböző regenerálódási fázisban lévő GGb-k POD-aktivitása Spathiphyllum floribundum 'Petite' in vitro tenyészetében.

A regeneráció során a POD-aktivitás időbeli lefutásának tendenciája némileg eltér a PBZkiegészítésü táptalajon mérthez képest, de ebben az esetben a triazolt (FP-t) már nem tartalmazták a táptalajok, a GGb-telepek regenerálódása $0,5 \mathrm{mgL}^{-1}$ BA táptalajon történt meg az FP-kezelések után. A sarjregeneráció végére azonban itt is minden esetben a kiindulásihoz képest kisebb POD érték áll be, a regeneráció elején pedig felfedezhető a POD-aktivitás emelkedése is (52. ábra).

\subsection{A Spathiphyllum sarjtenyészeteivel folytatott kísérletek}

\subsubsection{Különböző szénhidráttípusok hatásának vizsgálata}

A sarjak magasságának alakulására a különböző szénhidráttípusoknak az 5 mérési pont egyikénél vizsgálva sem volt statisztikailag kimutatható hatása, vagyis megállapítható, hogy a különböző szénhidráttípusok hatására ugyanolyan mértékben változik a sarjak magassága (melléklet 80. ábra).

Az új sarjak fejlődésének üteme látszik az 53. ábran. A kísérlet indítása utáni 2. héten még egyetlen sarj sem fejlődött a növényeken, ez a harmadik héten indult meg. A 4. héten már 0,8-3 db új sarj volt számolható a kezelt növényeken, szignifikáns különbség azonban ezek között nem volt. A különböző típusú szénhidrátok hatása a sarjfejlődés mértékére a 6 . héten kezdett szemmel láthatóvá válni, itt a glükóz hatására közel kétszer annyi új sarjat lehetett számolni, mint a szacharóz vagy fruktóz hatására, és megközelítőleg 4-szer annyit, mint a maltózos táptalajokon. A maltózos táptalaj hatása elmaradt a többi táptalaj hatásától, a kísérlet végére az átlagos legnagyobb sarjszám maltóz hatására nem érte el a 4-et. Az utolsó, 10. heti 
méréskor a glükóz előnye abszolút átlagértékben vizsgálva megmaradt, ám hatására egyes telepek 15-nél is több, mások pedig csak néhány sarjat fejlesztettek, tehát nem volt egyenletes a sarjfejlődés. A fruktóz esetében azonban a sarjtelepek kisebb szórással neveltek átlagosan 8,4 db új sarjat, így statisztikailag ez tekinthető a legjobb kezelésnek. A szacharóz jobb eredményt adott, mint a maltóz, de nem érte el a sarjak száma a glükózos vagy fruktózos kiegészítésű táptalajokon mérhető értékeket. A 8. hétnél a glükózkezeléshez tartozó érték hiányzik, mert fertőzés miatt nem lett volna elegendő tenyészet az utolsó, 10. heti mérési ponthoz is; így inkább a megmaradt növényeket az utolsó alkalommal mértem meg a jobb összehasonlíthatóság miatt.

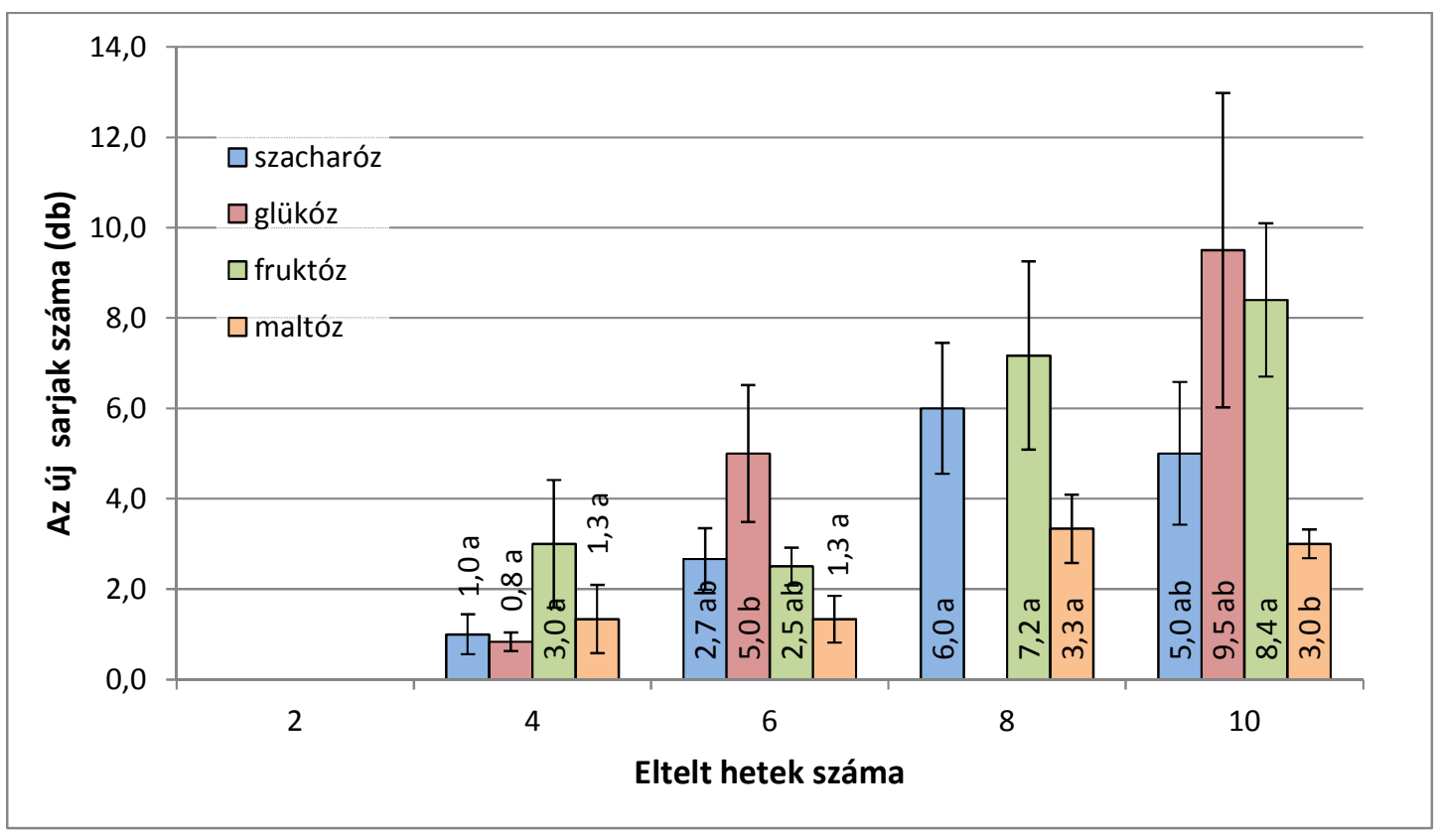

53. ábra. A különböző szénhidráttípusok hatása a sarjak számának alakulására kéthetes időközönként Spathiphyllum floribundum 'Petite' in vitro tenyészetében. A szignifikáns eltérések jelölése mérési pontokon belül a kezelések között értendő, Games-Howell teszt, p<0,05.

A levélszám fejlődése egyenletes mértékü mindegyik kezelés során a mérési pontok között, és adott mérési pontnál összehasonlítva az eltérő szénhidráttípusokat nagy különbségeket nem fedezhetünk fel. A maltóz hatására itt is jellemző volt, hogy kevésbé fejlődtek a növények az ezzel kiegészített táptalajokon, bár az eltérés statisztikailag nem jelentős (melléklet 81. ábra).

A levélfelület a levélszám növekedéséhez hasonlóan alakult (melléklet 82. ábra), ugyan a 10. héten a legtöbb levelet a fruktóztartalmú táptalajon lehetett számolni, a legnagyobb levélfelület mégis a szacharóz kiegészítésü táptalajokon fejlődő növényeken volt. A különbség a levélfelületek között azonban nem szignifikáns. A levélfelület növekedése mindegyik vizsgált szénhidrát hatására exponenciálisan alakult, a 8. hétig a növekmény mértéke kis mértékben változott, majd a 10. hétre viszonylag nagy ugrással megnőtt. Az exponenciális trendvonalat az áttekinthetőség megőrzése érdekében nem ábrázoltam a grafikonon, itt megadom az illesztési pontosságukat: $\mathrm{R}^{2}=0,80 ; 0,97 ; 0,93 ; 0,76$ rendre a szacharóz, glükóz, fruktóz, maltóz esetében. 
A sarjtelepek tömegnövekedése (54. ábra) is ezt az exponenciálisan emelkedő tendenciát követte (az illesztés szorossága $\mathrm{R}^{2}=0,99$ a fruktóz és maltóz esetében, $\mathrm{R}^{2}=0,93$ szacharóznál, és $\mathrm{R}^{2}=0,91$ glükóznál), a legmeredekebb emelkedést a fruktóz esetén lehetett tapasztalni, a sarjtelepek tömege ennél a szénhidrátnál lett a legnagyobb a 10. hét végére, szignifikánsan nagyobb, mint a legkisebb tömegnövekedést előidéző maltóz hatására. Az emelkedés jellege azonban a maltóz esetében is exponenciális, csak jóval kisebb meredekséggel.

A morfológiai paramétereket vizsgálva megállapítható, hogy a tesztelt szénhidrátok közül a leginkább pozitív hatással a fruktóz, majd a glükóz rendelkezik, ezután pedig a szacharóz, szignifikánsan még nem kimutatható lemaradással a vizsgált mintaelemszám mellett. A maltóz azonban kevésbé hasznosítható a növények számára exogén energiaforrásként, kisebb növekménnyel jellemezhetők a maltóz tartalmú táptalajon fejlődő növények.

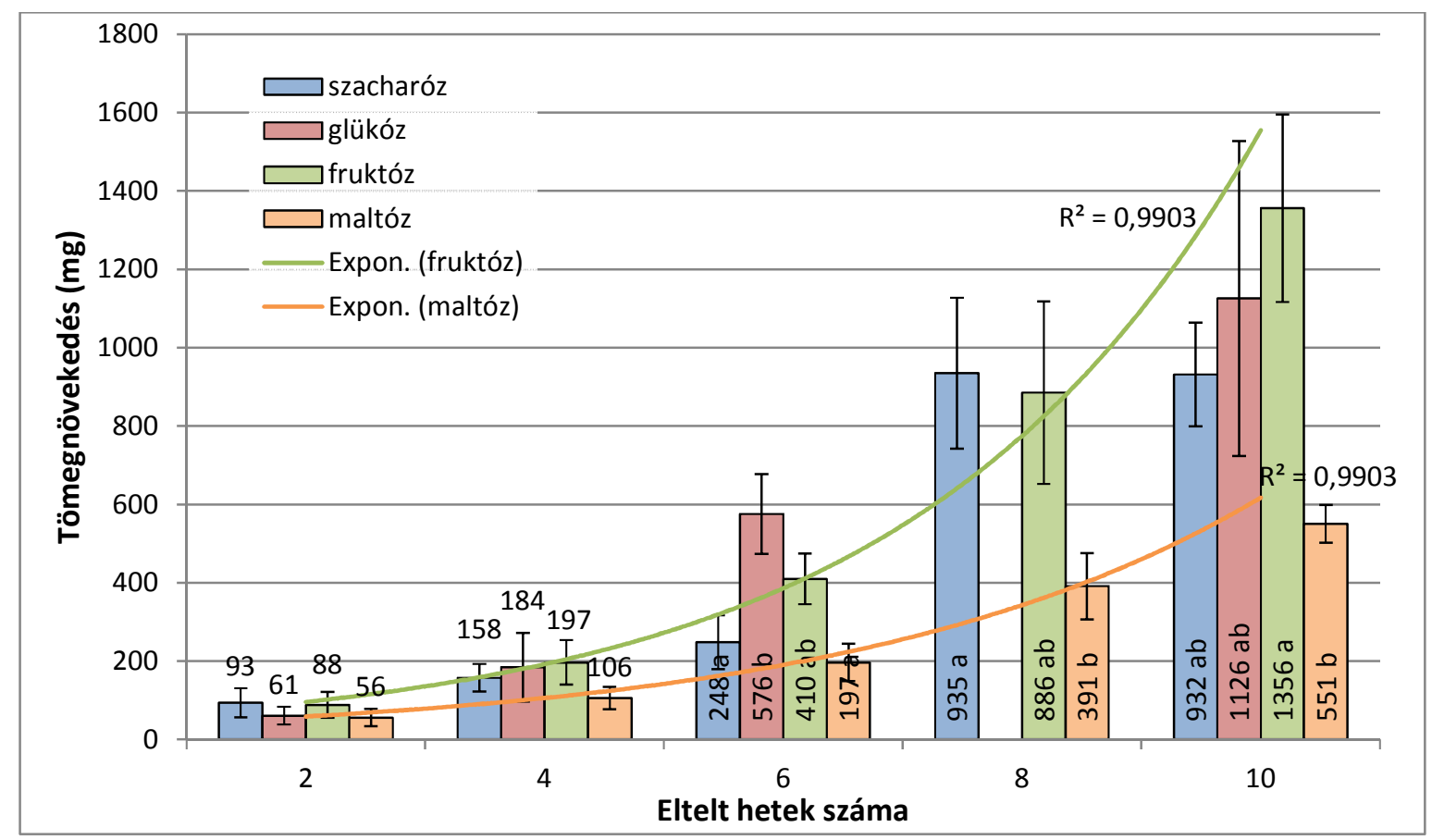

54. ábra. A különböző szénhidráttípusok hatása Spathiphyllum floribundum 'Petite' sarjtenyészeténél a sarjtelepek tömegnövekedésére kéthetes időközönként. A szignifikáns eltérések jelölése mérési pontokon belül a kezelések között értendö, Games-Howell teszt, p<0,05.

A növények gázcserejellemzői közül a transzspiráció az egyes szénhidráttípusok hatására adott vizsgálati időpontoknál nem mutatott különbségeket (melléklet 83. ábra), ám az idő elörehaladtával a növények egységnyi felületre számított transzspirációja kezdeti emelkedés után (4. hét) folyamatos csökkenést mutatott (6., 8., 10. hét).

A $\mathrm{CO}_{2}$ sztómakonduktancia értékek sem a szénhidráttípusok hatására mérési pontonként, sem a mérési pontok között átlagosan nem változtak számottevő mértékben (melléklet 84. ábra). A kiugró értékek esetén a szórás is nagy volt, ami inkább a mérés bizonytalanságát mutatja, semmint a kezelés hatását. Az utolsó mérési pontnál, a 10. héten a sztómakonduktancia 
szignifikánsan eltért a szénhidráttípusok hatására: a szacharóz és a maltóz, azaz a diszacharidok hatására alacsonyabb maradt, mint az egyszerü, monoszacharidok hatására.

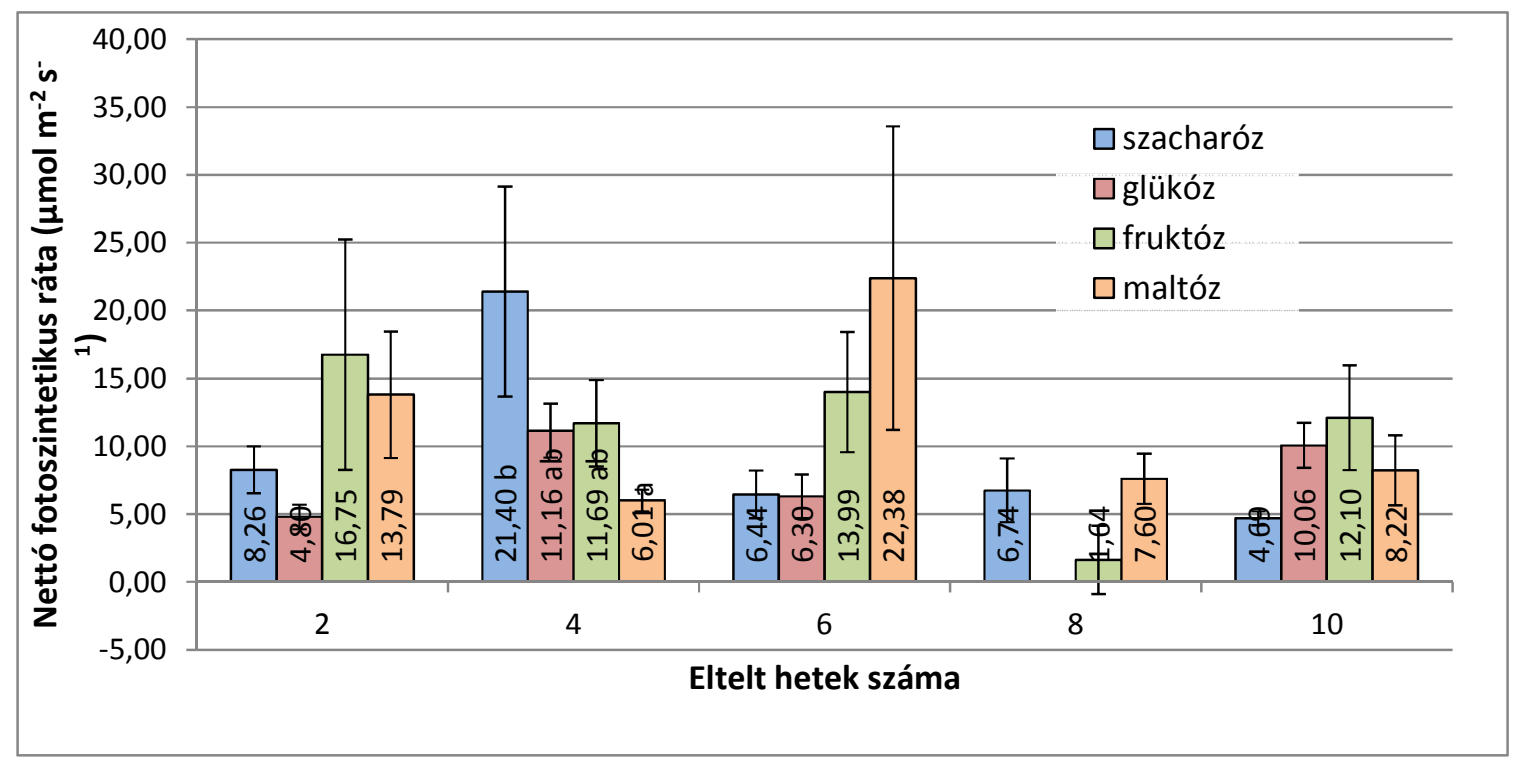

55. ábra. A különböző szénhidráttípusok hatása a nettó $\mathrm{CO}_{2}$ asszimilációs rátára Spathiphyllum floribundum 'Petite' sarjtenyészeténél kéthetes időközönként vizsgálva (mérési pontonként eltérö növényeken, n=6). A szignifikáns eltérések jelölése mérési pontokon belül a kezelések között értendő (Games-Howell teszt, p<0,05; hiányzó jelölés=nincs különbség).

Az 55. ábra a nettó fotoszintetikus rátát, a $\mathrm{CO}_{2}$-asszimiláció mértékét mutatja a kezelések hatására. A mérések itt is több esetben bizonytalanok voltak, illetve a különböző növények nagyon eltérő értékeket mutattak, ami az alacsony mintaelemszám (n=6) következménye. Egyértelmüen látszik viszont, hogy egy eset kivételével (8. hét, fruktózos táptalajok) az asszimilációs ráta értéke minden mérésnél pozitív volt, vagyis a növények több $\mathrm{CO}_{2}$-t vettek fel már az in vitro nevelés alatt is, mint amennyi felszabadult a légzésük során. A minták átlagértéke azonban a fruktózos táptalaj esetében (a 8 . heti mérési pontnál) is pozitív lett.

\subsubsection{Emelt makroelem- és szénhidrát-koncentráció hatásának vizsgálata}

A sarjszámokat vizsgálva statisztikailag jelentős eltérés csak az $1 \times \mathrm{MS}+20 \mathrm{gL}^{-1}$ szacharózt (10,5 db sarj) és $2 \times \mathrm{MS}+20 \mathrm{gL}^{-1}$ fruktózt (4,9 db sarj) tartalmazó táptalaj hatása között van. A többi kezelés hatására a sarjszám e két érték között alakul, de egyiktől sem tér el szignifikánsan. A 15,0 db átlagos sarjat mutató 1×MS + 40 gL $\mathrm{gL}^{-1}$ szacharózt tartalmazó táptalajú kezelés mellett a nagy szórás az oka annak, hogy a statisztikai elemzés szerint ez a kezelés is a köztes ('ab' jelzésű) csoportba került. A makroelem-koncentráció kétszeresre emelése azonos szénhidrát-koncentrációk mellett mindenhol csökkentette a sarjak számát, noha az alkalmazott statisztikai próba mellett ez nem mindig jelent meg kimutatható különbségként. Azonos makroelem-koncentrációk mellett a kétszeres szénhidráttartalmat összehasonlítva az egyszeressel nem kapunk jelentős különbségeket (56. ábra). 


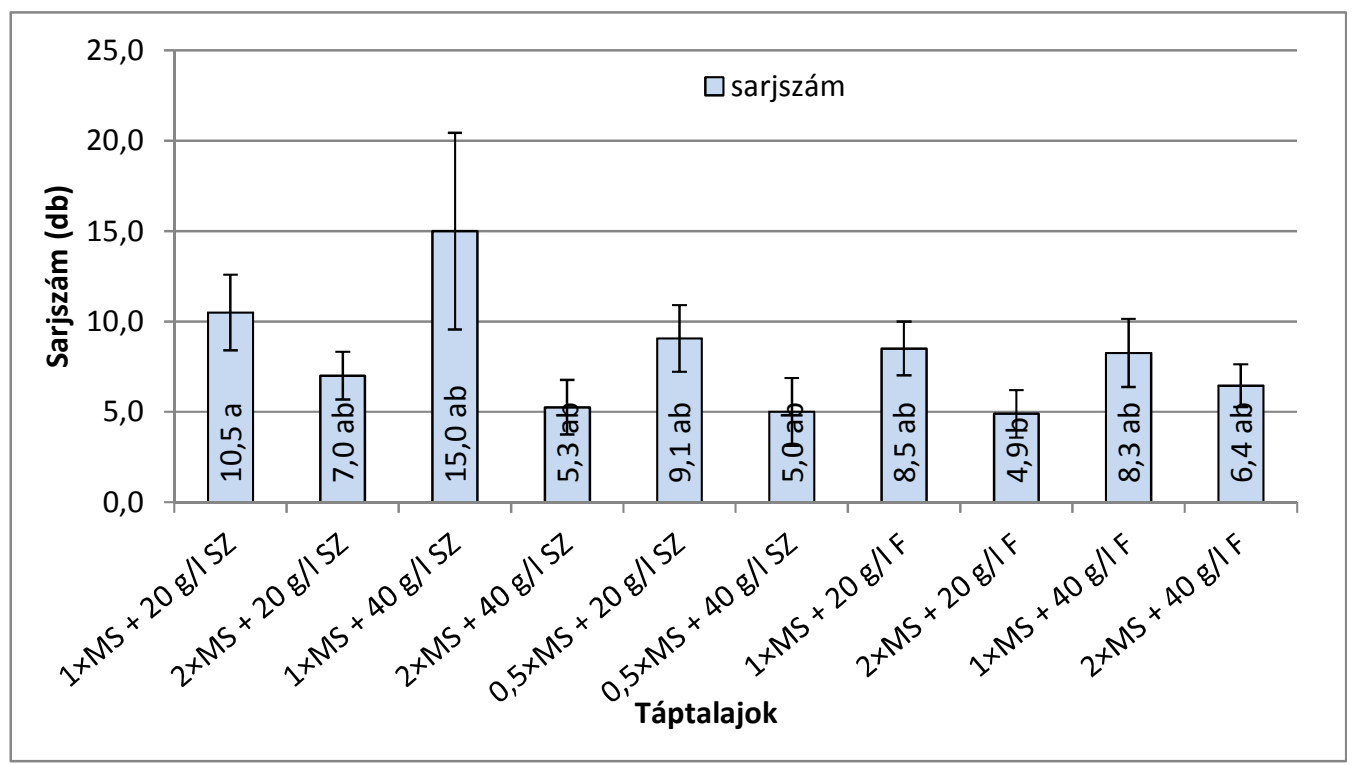

56. ábra. A különböző makroelem- és szénhidrát-koncentráció hatása a sarjszám változására sarjtelepek esetén, Games-Howell teszt, $\mathbf{p}<0,05$.

A sarjtelepeken belül a legnagyobb sarjmagasságot vizsgálva megállapítható, hogy a $40 \mathrm{gL}^{-1}$ szacharóz kiegészítésű táptalajok homogén csoportot alkotnak, közülük pedig az 1× MS + $40 \mathrm{gL}^{-1}$ szacharóz kezelés hatására szignifikánsan kisebb a sarjmagasság, mint bármelyik más $20 \mathrm{gL}^{-1}$ szacharózt, vagy a kétféle koncentrációjú fruktózt tartalmazó kezelés hatására. A legtöbb sarjat biztosító $1 \times \mathrm{MS}+20 \mathrm{gL}^{-1}$ szacharóz kezelés hatására a sarjmagasság nem törpül le. Ennél szignifikánsan nagyobb magasságot a $2 \times \mathrm{MS}+20 \mathrm{gL}^{-1}$ fruktóz hatására mértem, azon a táptalajon, ahol a legkisebb lett a sarjszám. Vagyis a növényi fejlődést nem gátolta a fruktóz, csak az iránya lett más, sarjfejlődés helyett a meglévő sarj hosszirányú növekedése volt erőteljes. A szénhidráttípus szerinti csoportátlagokat vizsgálva látszik, hogy a fruktóztartalmú táptalajok átlagosan nagyobb sarjmagasságot idéztek elő (57. ábra).

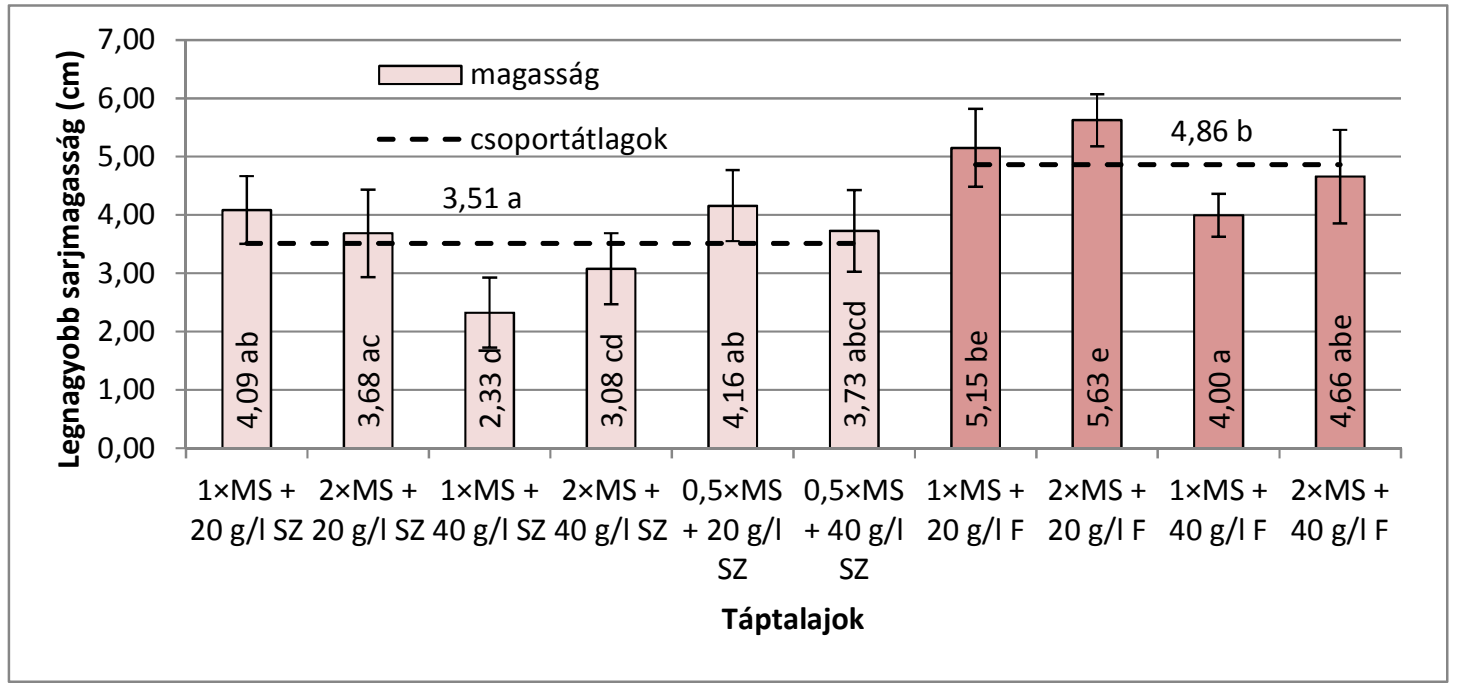

57. ábra. A különböző makroelem- és szénhidrát-koncentráció hatása a sarjmagasság változására, Games-Howell teszt $(\mathbf{p}<0,05)$, csoportátlagok között t-teszt $(\mathbf{p}<0,05)$. 
A levélszámok sarjankénti alakulásában leginkább a szénhidráttípus-csoportok szerint van különbség: a fruktózos táptalajokon átlagosan 3,98 db levél fejlödik egy sarjon, míg a szacharózos táptalajokon ez az érték 5,42. A t-teszt szerint a különbség szignifikáns $(\mathrm{p}<0,05)$ (58. ábra).

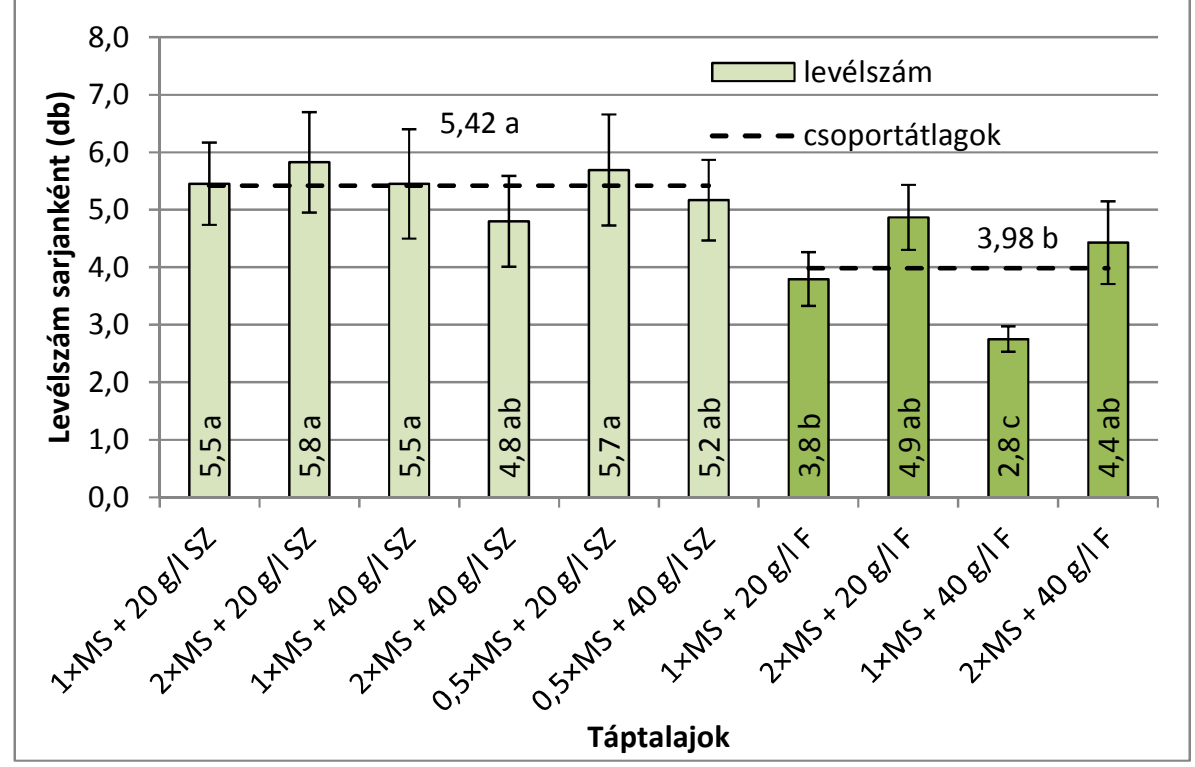

58. ábra. A különböző makroelem- és szénhidrát-koncentráció hatása a levélszám változására, Games-Howell teszt $(\mathbf{p}<0,05)$, csoportátlagok között t-teszt $(\mathbf{p}<0,05)$.

A fruktózos táptalajokon fejlődő sarjaknál a kisebb levélszám (58. ábra) nagyobb becsült egyedi levélterülettel párosul (59. ábra), vagyis a fotoszintetizáló felület aránya nem kisebb. Különösen igaz ez a $20 \mathrm{gL}^{-1}$ fruktóz kiegészítésü táptalajok esetén, viszont $40 \mathrm{gL}^{-1}$ fruktóz esetén már nem: a becsült levélterület feleakkora, mint $20 \mathrm{gL}^{-1}$ fruktóz használata esetén, ami statisztikailag nem tér el a $20 \mathrm{gL}^{-1}$ szacharóz hatásától e tekintetben. A levélterület a $40 \mathrm{gL}^{-1}$ szacharóz hatására is feleakkora vagy kisebb, mint $20 \mathrm{gL}^{-1}$ esetén, ha a makroelem $1 \times$ vagy $2 \times$ mennyiségü, ezekben az esetekben a többletcukor tehát nem járul hozzá a levélfelület növekedéshez, hanem csökkenti azt. Ellenben 0,5× makroelem-koncentráció esetén a megemelt szacharóztartalom nem csökkenti a levelek felületét. 


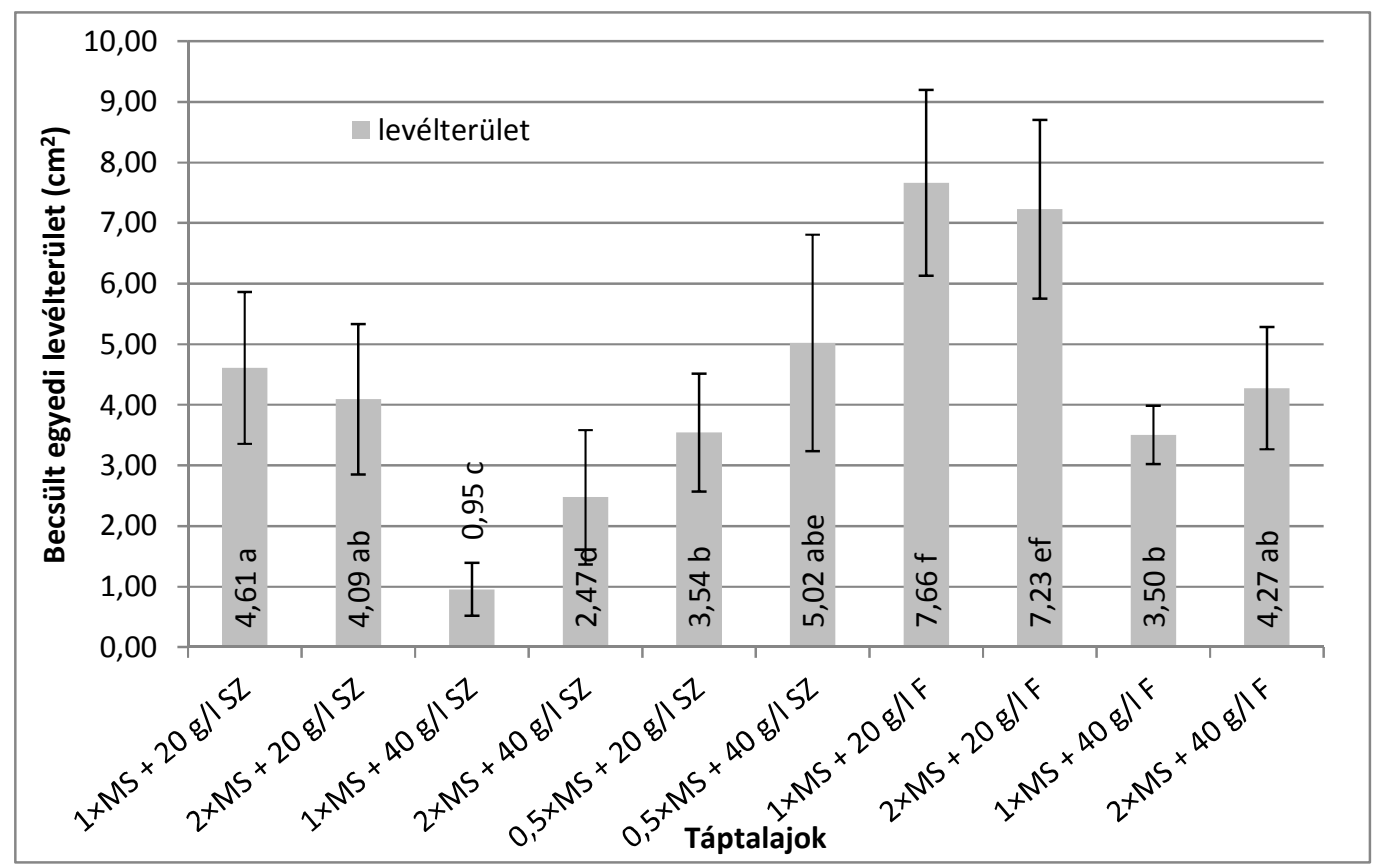

59. ábra. A különböző makroelem- és szénhidrát-koncentráció hatása a becsült egyedi levélterület alakulására, Games-Howell teszt $(\mathbf{p}<0,05)$.

A sarjtelepek tömegének vizsgálata során nem találtam jelentős eltéréseket a kezelések hatására (60. ábra). A kétszeresre növelt szénhidráttartalom az 1× és 2x makroelemkoncentrációk esetében is csökkenő sarjteleptömegeket okozott, de a különbség nem szignifikáns.

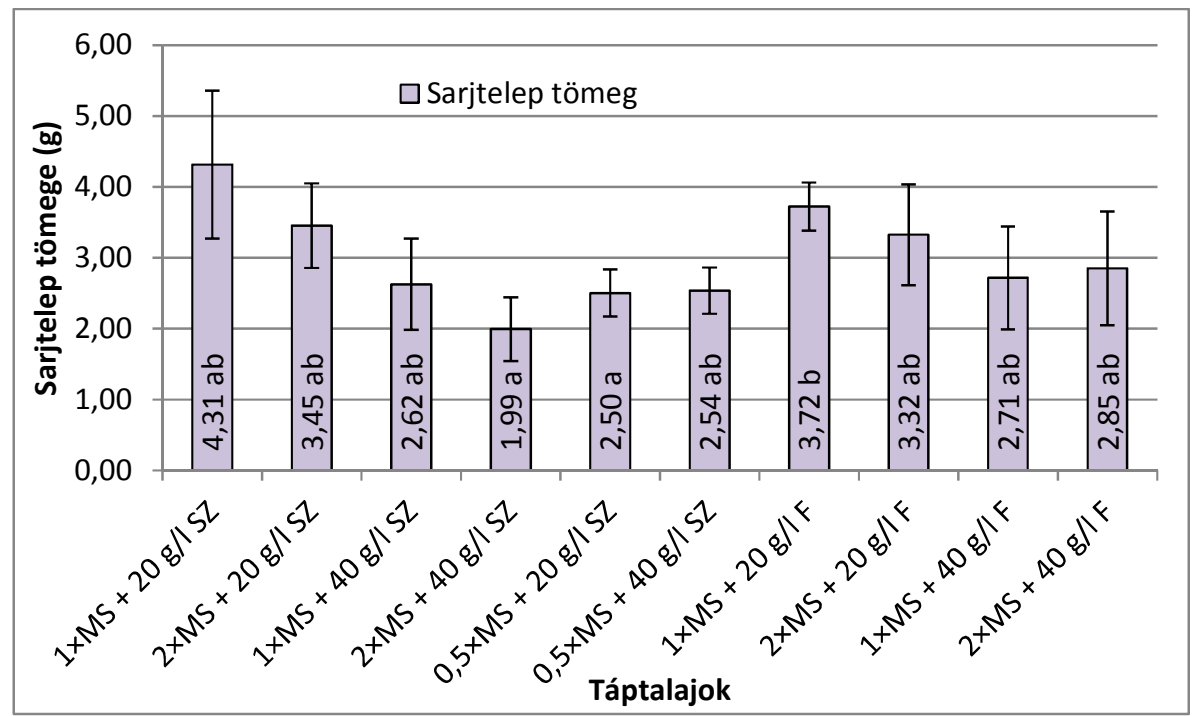

60. ábra. A különböző makroelem- és szénhidrát-koncentráció hatása a sarjteleptömeg változására, Games-Howell teszt $(\mathbf{p}<0,05)$. 
A sarjteleptömegeknek megfelelöen alakult a fajlagos sarjtömegek tendenciája is: kis, nem szignifikáns különbségek jelentek meg a 20 és $40 \mathrm{gL}^{-1}$ szacharóz- vagy fruktózkoncentráció következtében 1× és 2× makroelem-koncentrációnál: a kétszeres szénhidrátmennyiség kisebb fajlagos tömeget idézett elö. 0,5× makroelem-mennyiségnél viszont megnövelte a fajlagos tömeget, de itt sem szignigikánsan (61. ábra).

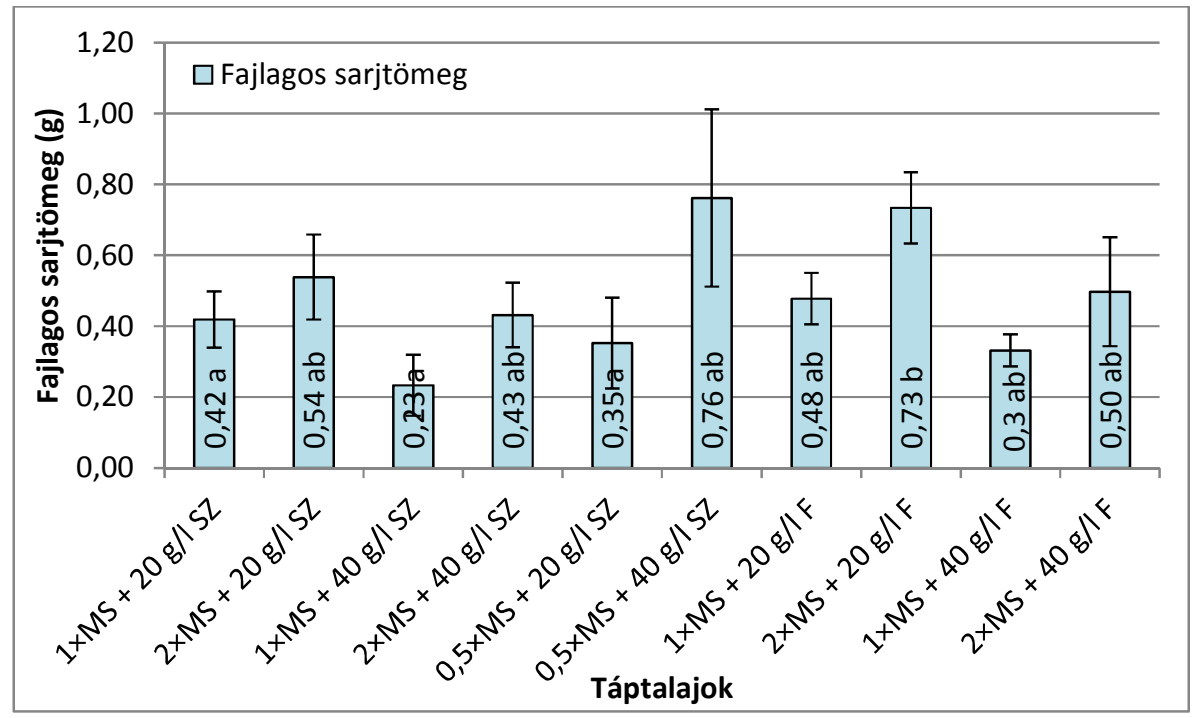

61. ábra. A különböző makroelem- és szénhidrát-koncentráció hatása a fajlagos sarjtömeg változására, Games-Howell teszt $(\mathbf{p}<0,05)$.

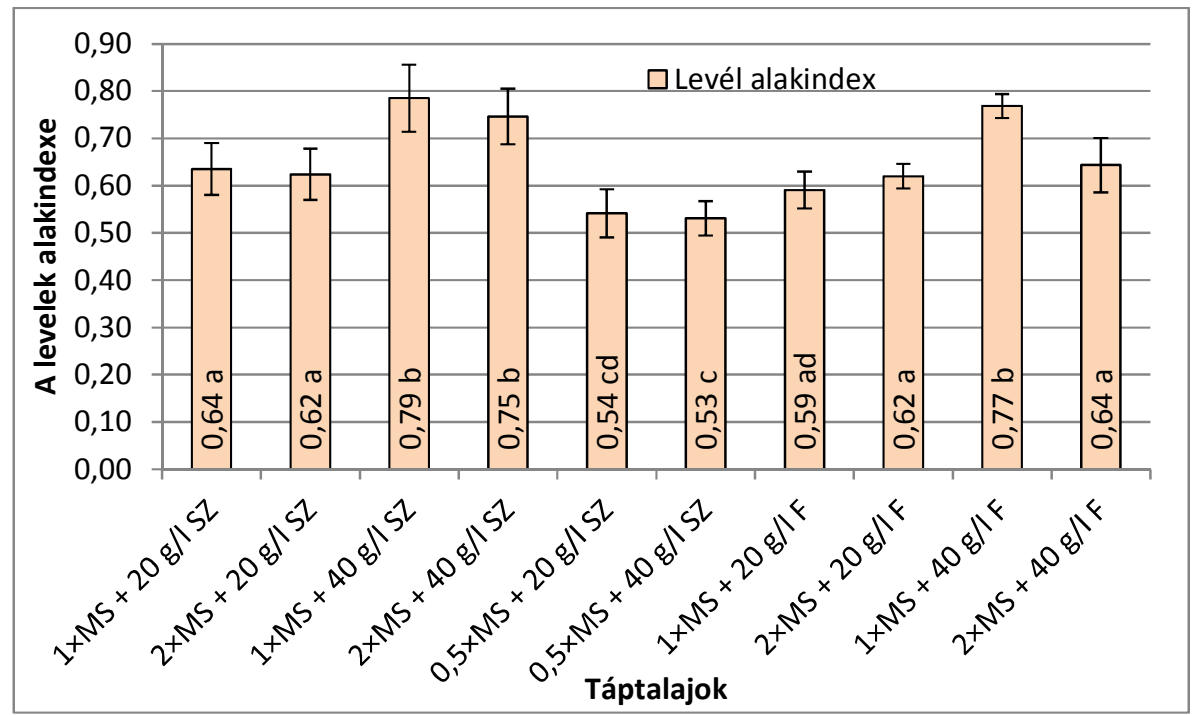

62. ábra. A különböző makroelem- és szénhidrát-koncentráció hatása a levelek alakindexének változására, Games-Howell teszt $(\mathbf{p}<0,05)$.

A 62. ábra a levél alakindexek, vagyis a levélforma változását mutatja a kezelések hatására. A magasabb szénhidrát-koncentráció megnyúltabb levelek fejlődését idézte elő (az 
index értéke közelebb van 1-hez), a különbség a szacharóznál 1× és 2× makroelem koncentráció esetén is, a fruktóznál 1× makroelem-mennyiség esetén szignifikáns, 2×-nél is nagyobb az index, de nem jelentősen. 0,5× makroelem-mennyiség esetén az eltérő szénhidrát-koncentráció megint nem mutatott különbséget.

A klorofilltartalom az $1 \times$ és $2 \times$ makroelem-mennyiségek mellett mind a szacharóz, mind a fruktóz koncentrációjának megkettőzésével csökken, de nem szignifikánsan, kivéve az 1× MS+ $40 \mathrm{gL}^{-1}$ szacharóz esetén, ahol rendkívül kis klorofilltartalmat mértem (63. ábra). Ezen a táptalajon a növények levele szemmel láthatólag is nagyon klorotikus volt, így a mérési hiba kizárható. A 0,5×-ös makroelem-koncentráció esetén a szacharózmennyiség megduplázása jobb eredményt (nagyobb klorofilltartalmat) adott, de nem szignifikáns a különbség, hasonlóan, mint a fajlagos levélterület és a fajlagos sarjtömeg paraméterek vizsgálata esetén. A $20 \mathrm{gL}^{-1}$ fruktózkiegészítésü táptalajok némileg, de nem jelentősebben nagyobb klorofilltartalmat idéztek elő, mint a $20 \mathrm{gL}^{-1}$ szacharózkiegészítésüek. A makroelem-koncentrációknak külön nem volt jelentős hatásuk a klorofilltartalomra azonos mennyiségü szénhidrátok használata esetén. A klorofill $a / b$ arány alakulását is feltüntettem a 63. ábrán. Minden kezelésnél jellemző, hogy a klorofill $a$ aránya az 50-60 \%-os tartományba esik, a klorofill $b$ pedig ennek megfelelően 40$50 \%$. A makroelem- és szénhidrát-koncentráció tehát a klorofill $a / b$ arányt nem változtatja a növényben, csak az abszolút klorofilltartalmat.

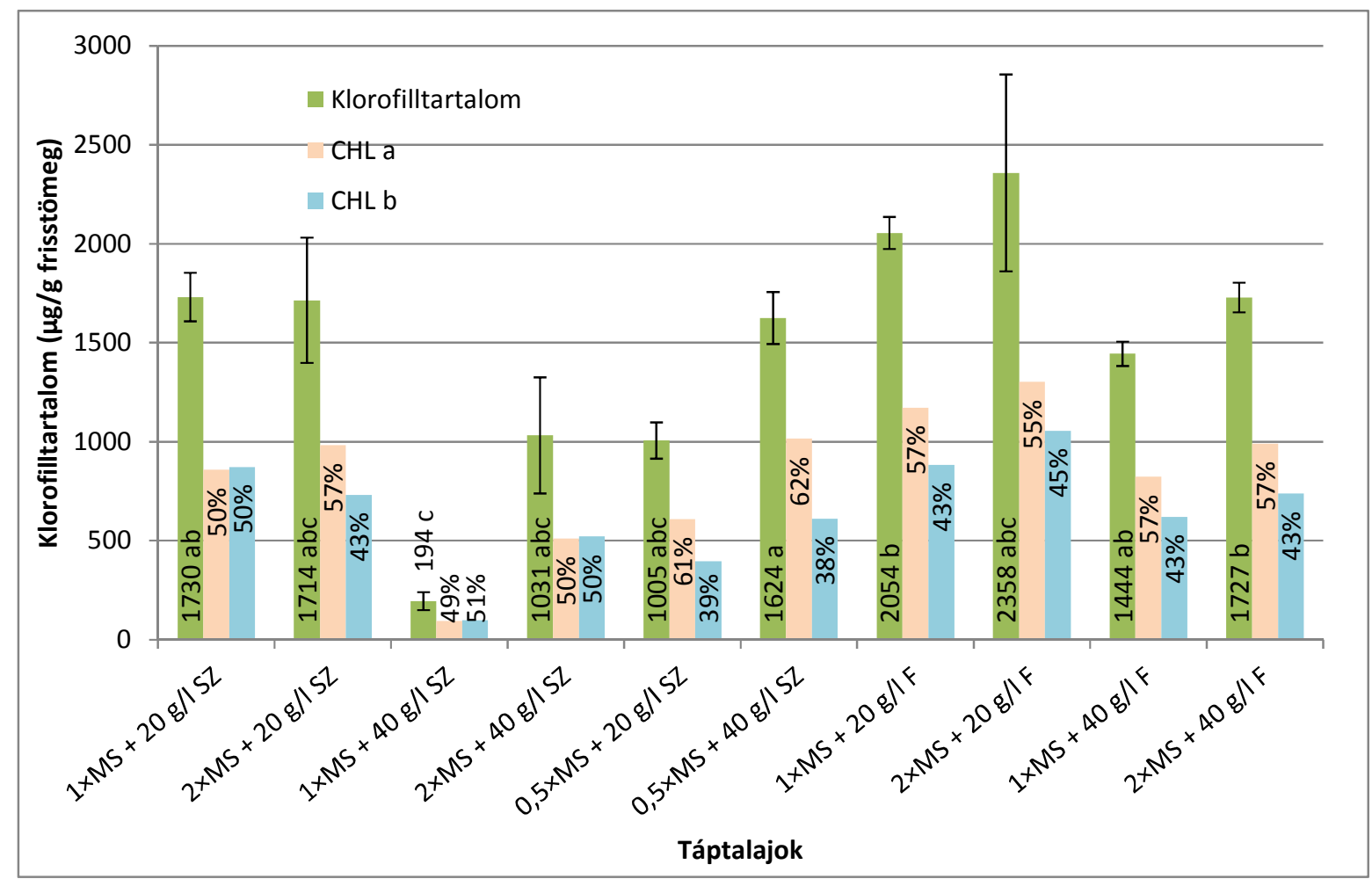

63. ábra. A különböző makroelem- és szénhidrát-koncentráció hatása a sarjak klorofilltartalmának alakulására, Games-Howell teszt $(\mathbf{p}<\mathbf{0 , 0 5})$. 
A 64. ábra a kezelt növények szárazanyag-tartalma közötti különbségeket mutatja. Szignifikáns eltérések a kezelések hatására kevés esetben jelennek meg, a 2× makroelem koncentráció kombinálva $40 \mathrm{gL}^{-1}$ szacharóz- vagy fruktózkiegészítés hatására nagyobb szárazanyag-tartalmat okoz, a legtöbbet az $1 \times$ és $2 \times$ makroelem $+40 \mathrm{gL}^{-1}$ fruktóz kiegészítés mellett. A szénhidrát szerinti csoportátlagokat vizsgálva megállapítható, hogy a fruktóz hatására általában nagyobb a növények szárazanyag-tartalma, a t-teszt alapján ez az eltérés szignifikáns $(\mathrm{p}<0,05)$.

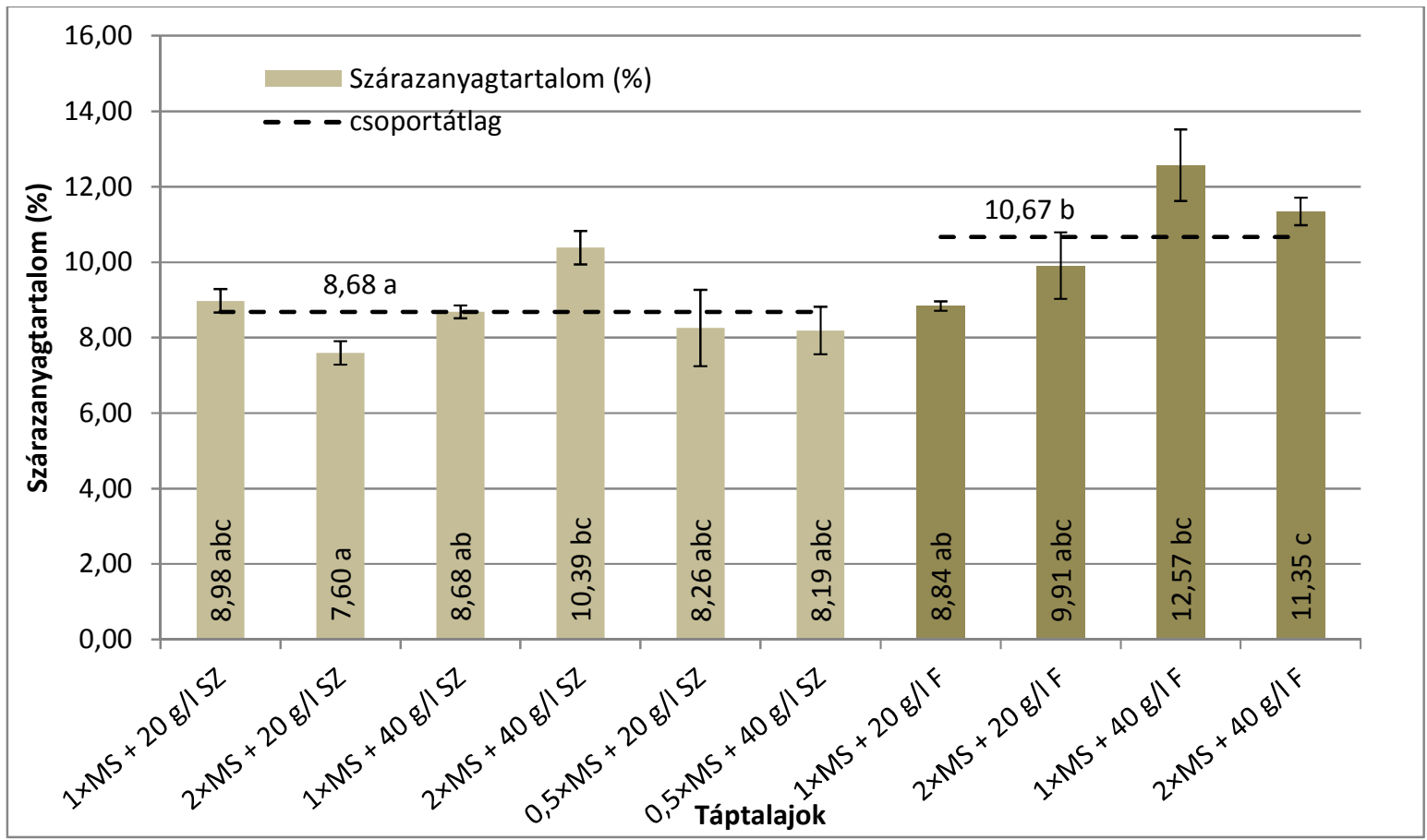

64. ábra. A különböző makroelem- és szénhidrát-koncentráció hatása a növények szárazanyag-tartalmának változására, Games-Howell teszt $(\mathbf{p}<0,05)$, csoportátlagok között t-teszt $(\mathbf{p}<0,05)$.

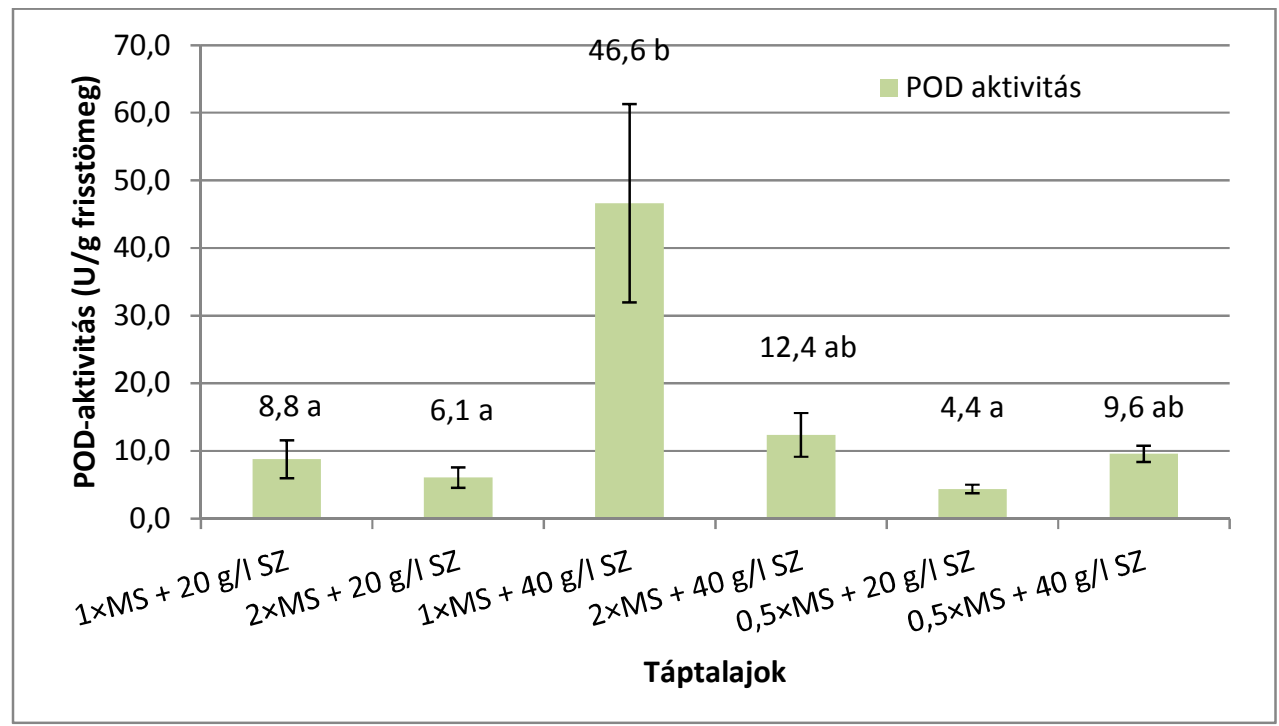

65. ábra. A különböző makroelem- és szénhidrát-koncentráció hatása a sarjak levélszöveti POD-aktivitására, Games-Howell teszt $(\mathbf{p}<\mathbf{0 , 0 5})$. 
A levelek POD-aktivitás értékét mutatja a 65. ábra, ahol a szacharózt tartalmazó kezelésekben részesült növényeknél mértem a peroxidázenzim aktivitását. A kezelések között csak az 1× makroelemkoncentráció mellett kétszeresre emelt szénhidrátkoncentráció okozott jelentősen nagyobb POD-aktivitást a növényekben. A többi esetben a $40 \mathrm{gL}^{-1}$ szacharóz a $20 \mathrm{gL}^{-1}$-hez képest nem növelte a POD-aktivitást. A makroelem-koncentrációnak nem volt hatása a POD-aktivitás változására a sarjtenyészeteknél szemben a GGb-telepekkel. A sarjtenyészetek levélből mért POD-aktivitása nagyjából egy nagyságrenddel kisebb, mint az azonos táptalajokon fejlődő GGb-tenyészeteké, a GGb-tenyészetek POD-aktivitása csak a triazolokkal kiegészített táptalajokon alakul a sarjakéval azonos nagyságrendben.

\subsubsection{A paklobutrazol hatásának vizsgálata}

\subsubsection{A növények morfológiai paramétereire gyakorolt hatás}

A PBZ-kezelések sem azonnal, sem az utóhatás során nem befolyásolták a sarjadzás mértékét a kontrollhoz képest (66. ábra). A kezelések hatására az átlagos sarjmagasság szignifikánsan kisebb volt, mint a kontrollnál mérhető, de a koncentrációk között nem volt nagy különbség. Az utóhatás-vizsgálat során a növekedésszabályozó-mentes táptalajon a két alacsonyabb PBZ-koncentrációjú kezelésben részesült növények magassága normalizálódott, és elérte a kontroll szintjét, míg a magasabb PBZ-koncentrációk utóhatása továbbra is mérhető volt (66. ábra).

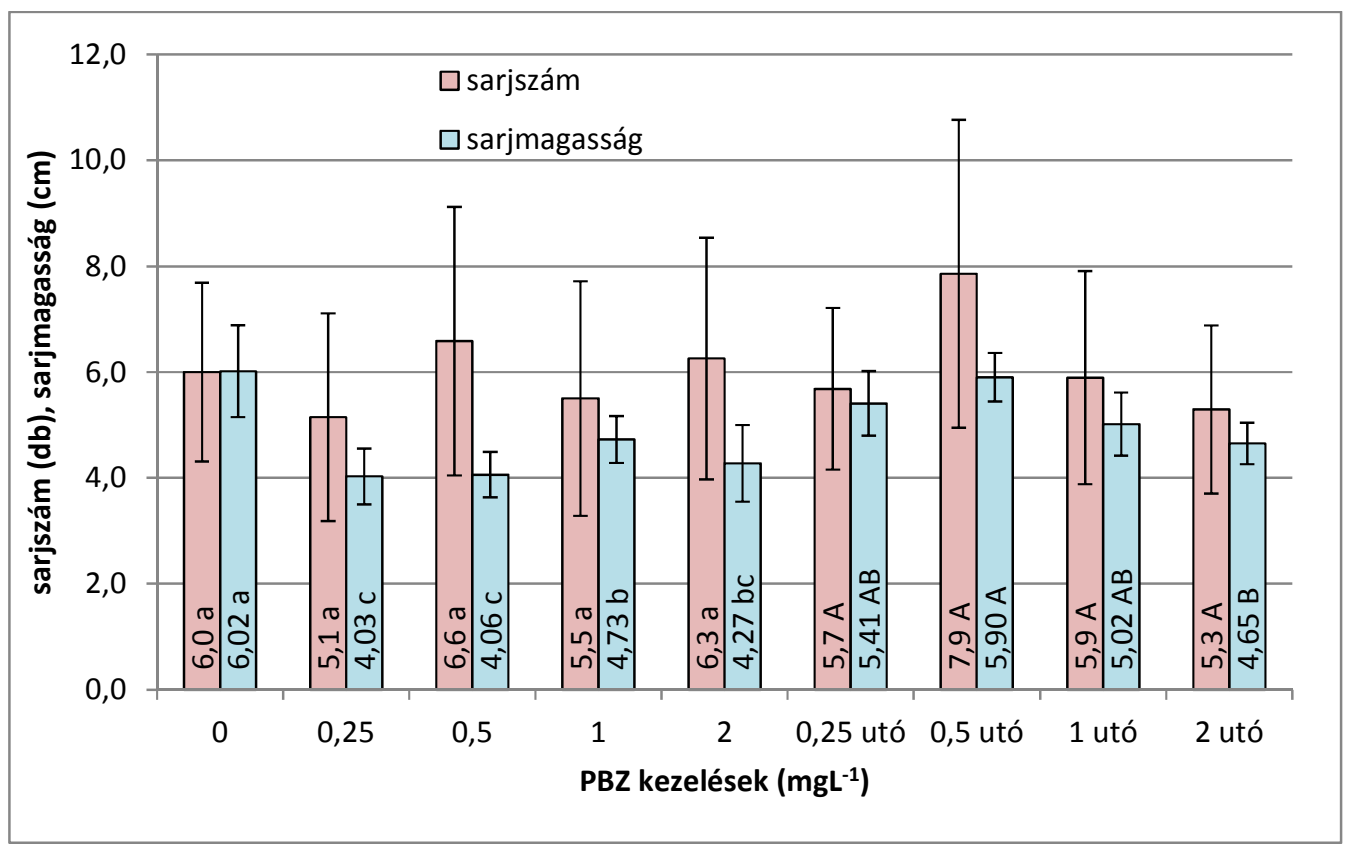

66. ábra. A PBZ-kezelések hatásának vizsgálata Spathiphyllum floribundum 'Petite' sarjtenyészeténél a sarjszám és sarjmagasság alakulására (az eltérő betủk szignifikáns különbséget jelölnek, külön értendő a kezelésnél és az utóhatásvizsgálatnál, Games-Howell teszt, p<0,05). 
A PBZ-kezelés a sarjcsomók tömegét is csökkentette, a kontrollhoz képest szignifikánsan, de a koncentrációk között itt sem volt eltérés. Az utóhatás-vizsgálatnál a sarjcsomók tömege szintén normalizálódni kezdett, minél magasabb volt a PBZ koncentrációja a kezelésnél, annál nagyobb lett utólag a sarjcsomók tömege (bár a különbség nem volt szignifikáns), a legnagyobb koncentráció esetében elérte a kontroll szintjét is. A fajlagos levélszám alakulása közvetlenül a kezelés után nem mutatott különbségeket, utólag viszont a két alacsonyabb PBZ-koncentráció hatására fejlődött több levél (67. ábra).

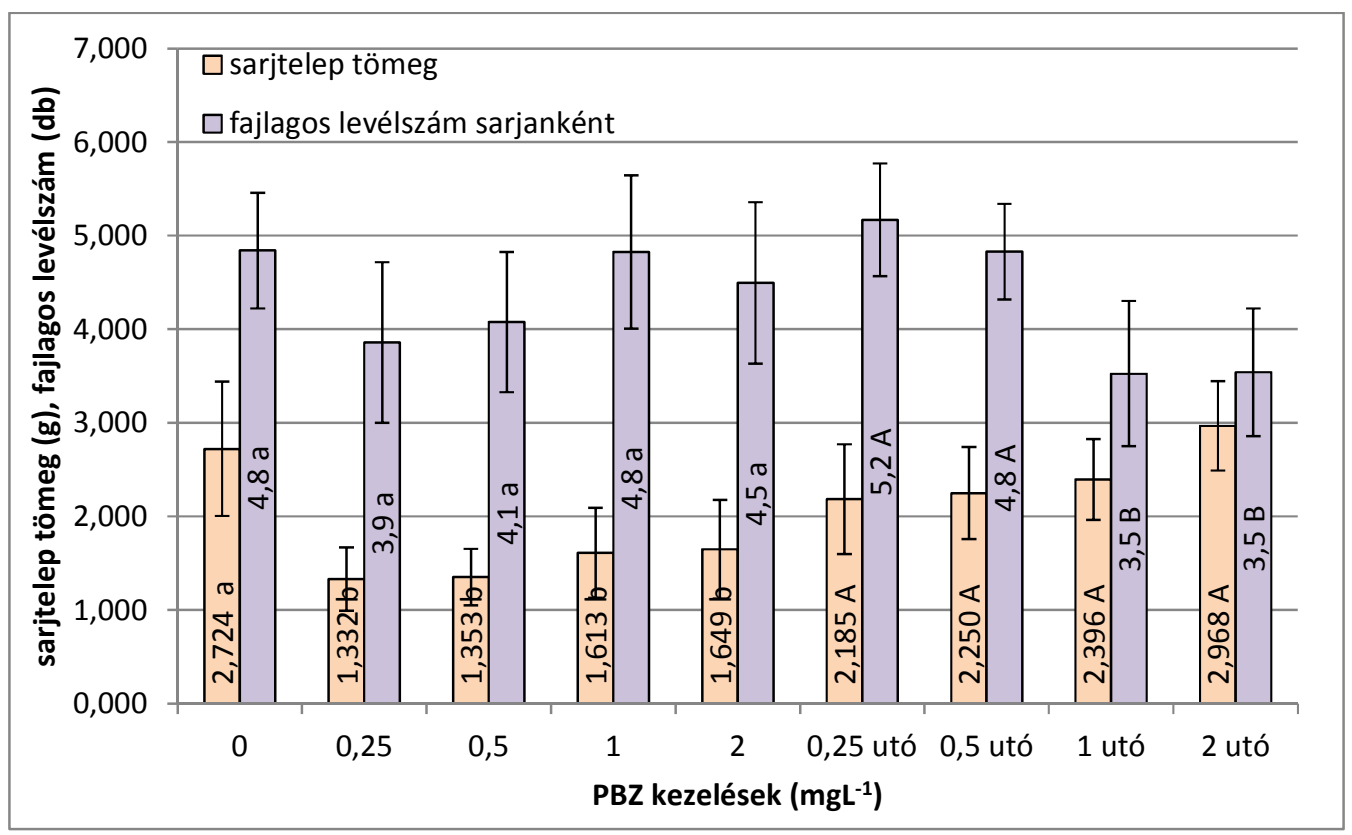

67. ábra. A PBZ-kezelések hatásának vizsgálata Spathiphyllum floribundum 'Petite' sarjtenyészeténél a sarjteleptömeg és a fajlagos (sarjankénti) levélszám alakulására (az eltérő betűk szignifikáns különbséget jelölnek, külön értendő a kezelésnél és az utóhatásvizsgálatnál, Games-Howell teszt, p<0,05).

A gyökérszám a PBZ-kezelés után közvetlenül a kontrollal azonos módon alakultak, a legkisebb PBZ-koncentrációt kivéve, ahol szignifikánsan kevesebb gyökér képződött. Utólag azonban a két kisebb PBZ-koncentrációjú kezelésben részesült növények mutattak szignifikánsan nagyobb gyökeresedést, $0,5 \mathrm{mgL}^{-1} \mathrm{PBZ}$ kezelés utóhatásának következtében a dupláját a két magasabb PBZ-koncentrációénak (68. ábra). A szárazanyag-tartalom nem mutatott eltéréseket a PBZ-kezelések utóhatásvizsgálatakor (melléklet 85. ábra). 


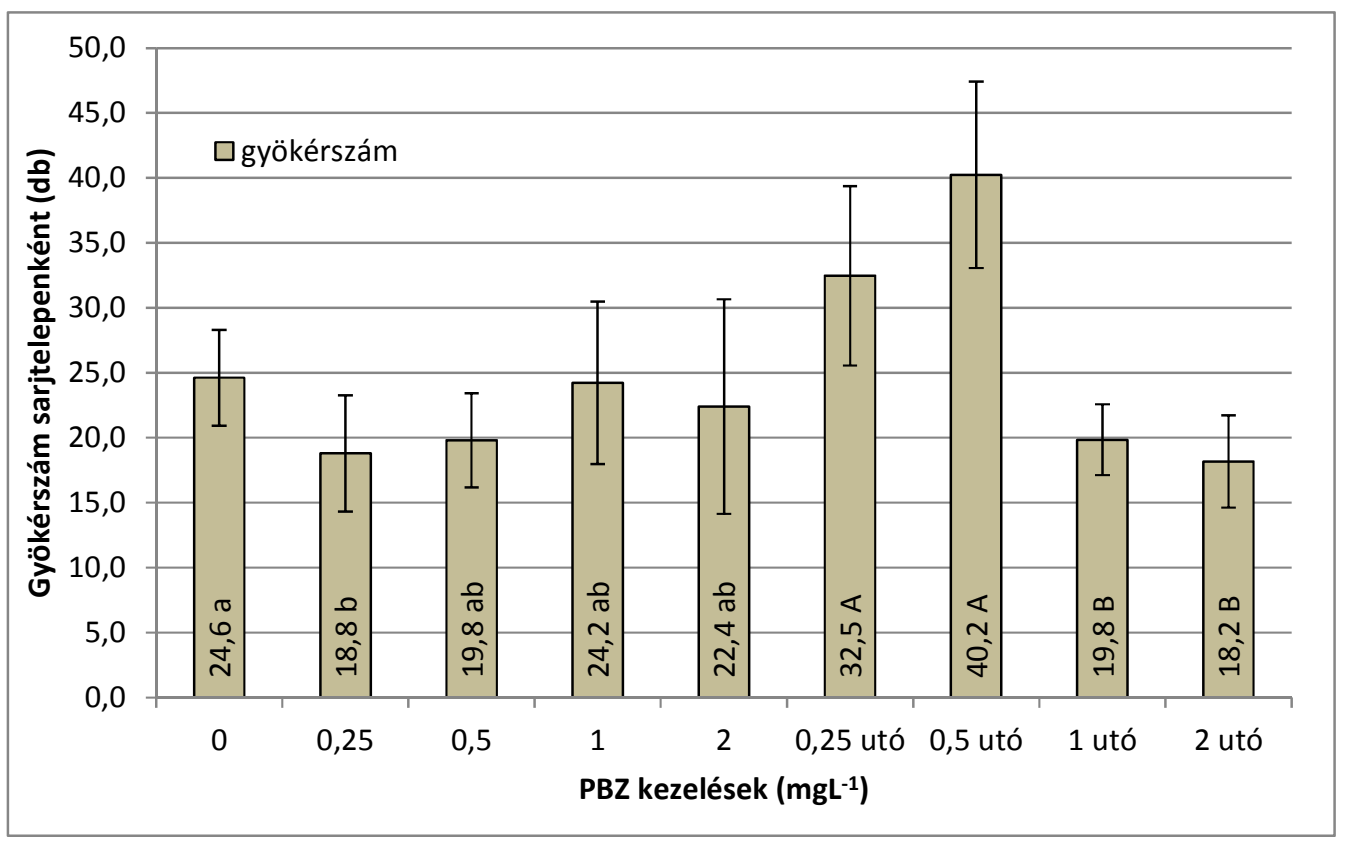

68. ábra. A PBZ-kezelés hatásának vizsgálata Spathiphyllum floribundum 'Petite' sarjtenyészeténél a gyökérszám alakulására (az eltérő betük szignifikáns különbséget jelölnek, külön értendő a kezelésnél és az utóhatásvizsgálatnál, Games-Howell teszt, $\mathbf{p}<\mathbf{0 , 0 5}$ ).

\subsubsection{Fotoszintetikus ráta, sztómakonduktancia, transzspiráció}

A PBZ-kezelések a kontrollhoz képest nem befolyásolták számottevően a növények transzspirációját (69. ábra) és a $\mathrm{CO}_{2}$ sztómakonduktanciáját (melléklet 86. ábra), ellenben a nettó $\mathrm{CO}_{2}$ asszimilációs ráta a $0,25 \mathrm{mgL}^{-1} \mathrm{PBZ}$-koncentráció mellett szignifikánsan nagyobb volt a kontrollhoz képest (közel 4-szeres a különbség) (70. ábra). A PBZ-koncentráció növekedésével azonban csökken a fotoszintetikus ráta, és a különbség fokozatosan eltünik a kontrollhoz képest.

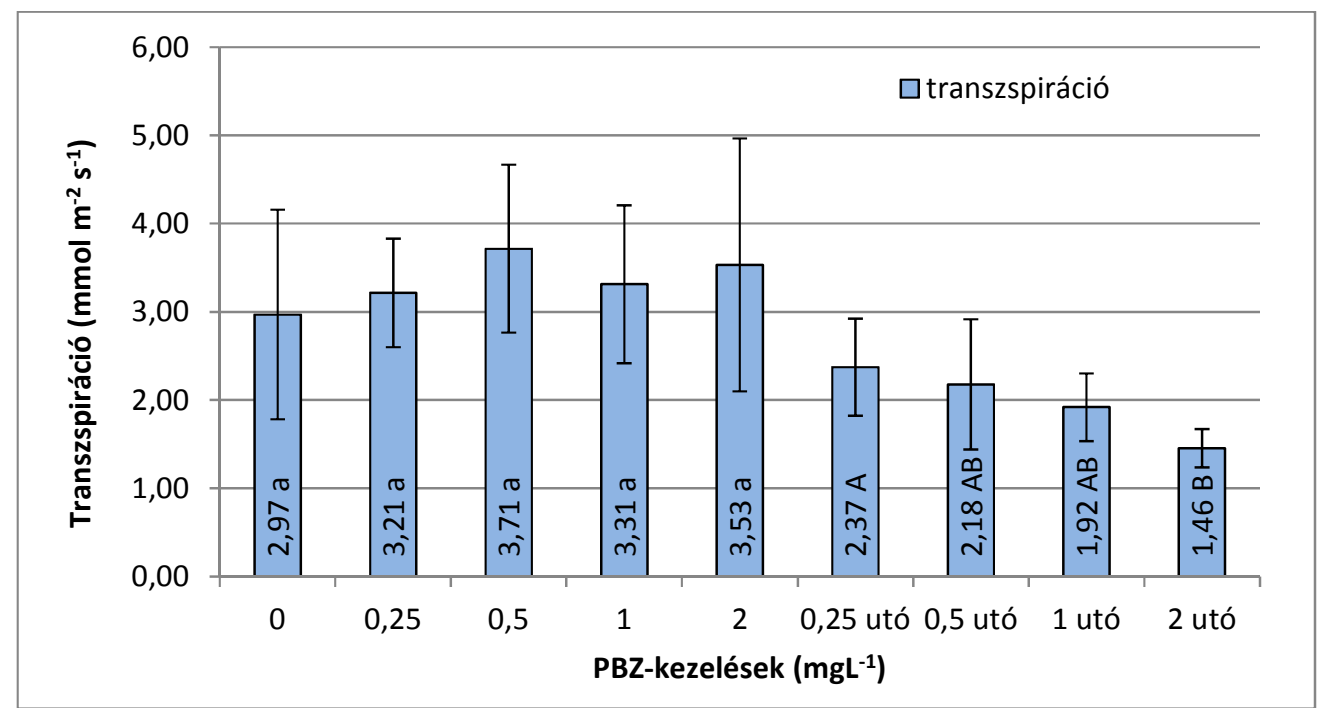

69. ábra. A PBZ-kezelések hatásának vizsgálata Spathiphyllum floribundum 'Petite' sarjtenyészeténél a transzspiráció alakulására (az eltérö betűk szignifikáns különbséget jelölnek, külön értendő a kezelésnél és utóhatásvizsgálatnál Games-Howell teszt, p<0,05). 


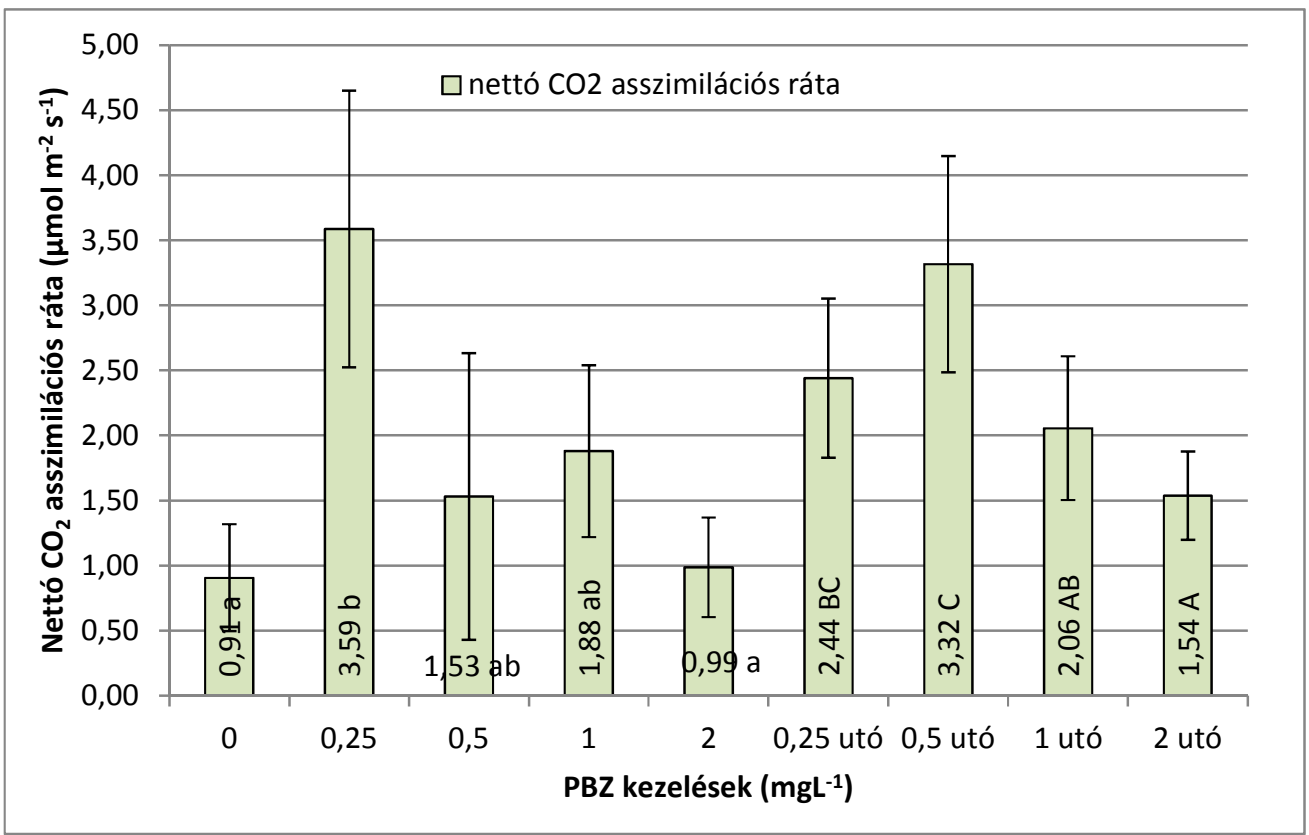

70. ábra. A PBZ-kezelések hatásának vizsgálata Spathiphyllum floribundum 'Petite' sarjtenyészeténél a nettó $\mathrm{CO}_{2}$ asszimilációs ráta alakulására (az eltérö betük szignifikáns különbséget jelölnek, külön értendő a kezelésnél és utóhatásvizsgálatnál Games-Howell teszt, p<0,05).

A PBZ-kezelések utóhatás-vizsgálata során kiderült, hogy a továbbra is fennálló fotoszintetikus aktivitásbeli (nettó $\mathrm{CO}_{2}$-asszimilációs ráta) eltérések mellett (70. ábra) jelentős különbségek jönnek létre a transzspiráció (69. ábra) és a $\mathrm{CO}_{2}$ sztómakonduktancia (melléklet 86. ábra) tekintetében is az egyes kezelésben részesült növények között. A nettó $\mathrm{CO}_{2}$-asszimilációs rátát tekintve a kezelések utóhatása még mérhető volt: az eredeti kontrollhoz képest a három alacsonyabb koncentrációjú PBZ-kezelés után is nagyobb maradt a $\mathrm{CO}_{2}$-megkötés a növényekben (kontroll $0,91 \mu \mathrm{mol} \mathrm{m} \mathrm{m}^{-2} \mathrm{~s}^{-1}$ (a); a PBZ kezelések utóhatásai rendre a koncentráció

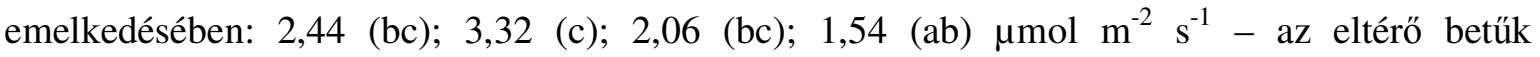
szignifikáns különbségeket jelölnek a Games-Howell (p<0,05) teszt alapján - megjegyzés: a 70. ábra nem veti össze a kontrollt az utóhatás kezelésekkel). Legnagyobb mértékben a 0,5 mgL ${ }^{-1}$-es PBZ-koncentrációjú kezelésben részesült növények mutattak utóhatást, ettől szignifikánsan nem tért el a 0,25 és $1 \mathrm{mgL}^{-1}$ koncentráció sem, de a $2 \mathrm{mgL}^{-1}$ utóhatása már számottevően kisebb értéket eredményezett, ami a kontrollnak megfelelő szint. A transzspiráció mértéke ezzel szemben az utóhatás során rendre a kontroll érték alá került, és fokozatosan csökkenő tendenciát mutatott a PBZ-koncentrációjának növekedésével (69. ábra). A transzspirációból származtatható sztómakonduktancia értékek hasonlóan alakultak: a $2 \mathrm{mgL}^{-1}$ koncentráció utóhatásának következtében szignifikánsan kisebb volt a növények sztómakonduktanciája a kisebb koncentrációkhoz képest (melléklet 86. ábra). 


\subsubsection{Szövettani vizsgálatok}

A szövettani vizsgálatok a kezelések utóhatásvizsgálata során történtek. A sztómaanatómiai vizsgálatok szerint a légrések szélessége és hossza a három kisebb PBZ-

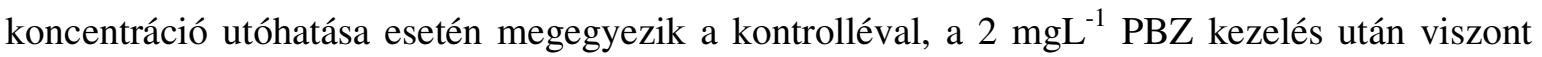
szignifikánsan nagyobbak ezek a méretek (71. ábra), ennek következtében az e két értékből számított pórusterület is ennél a koncentrációnál szignifikánsan nagyobb a kontroll és a kisebb koncentrációjú kezelésekkel összehasonlítva. A zárósejtek méretei (hossz és szélesség) a PBZkoncentráció emelésével a kontrollhoz képest fokozatosan nőnek. A sztómák méretei tehát minden tekintetben változnak a kontroll kezelés növényein mérhetőhöz képest a legnagyobb PBZ-koncentráció utóhatására, ám előfordulási gyakoriságuk adott területre számítva nem változik. A színi és fonáki sztómák aránya azonban megváltozik a kezelések hatására: míg a kontroll esetében 3,27-szer több gázcserenyílás található a levelek fonákán, addig ez az arány a PBZ-kezeléseknél minden esetben 2,6 alatti. A 0,5 $\mathrm{mgL}^{-1}$ PBZ kezelés hatására a legkisebb a különbség: csupán 2,06-szoros a fonáki sztómák száma a színihez képest (11. táblázat).

11. táblázat. A PBZ-kezelések hatása Spathiphyllum floribundum 'Petite' hajtástenyészetében a sztómaanatómiai paraméterek alakulására

\begin{tabular}{|c|c|c|c|c|c|}
\hline \multirow{2}{*}{ Sztómaanatómiai paraméterek } & \multicolumn{5}{|c|}{ PBZ kezelések koncentrációja $\left(\mathrm{mgL}^{-1}\right), \mathrm{n}=56-123$} \\
\hline & 0 & 0,25 & 0,5 & 1 & 2 \\
\hline Légrésszélesség $(\mu \mathrm{m})$ & $3,7 \pm 0,1 \mathrm{a}^{1}$ & $3,6 \pm 0,1 \mathrm{a}$ & $3,6 \pm 0,1 \mathrm{a}$ & $3,4 \pm 0,1 \mathrm{a}$ & $4,4 \pm 0,1 \mathrm{~b}$ \\
\hline Légréshossz ( $\mu \mathrm{m})$ & $9,5 \pm 0,1 \mathrm{a}$ & $9,6 \pm 0,2 \mathrm{a}$ & $9,6 \pm 0,2 \mathrm{a}$ & $9,7 \pm 0,1 \mathrm{a}$ & $12,7 \pm 0,3 b$ \\
\hline Zárósejtek hossza $(\mu \mathrm{m})$ & $14,4 \pm 0,1 \mathrm{ce}$ & $15 \pm 0,3$ de & $15,9 \pm 0,2 \mathrm{bd}$ & $16 \pm 0,2 \mathrm{bc}$ & $19,7 \pm 0,3 \mathrm{a}$ \\
\hline Zárósejtek szélessége ( $\mu$ m) & $13,9 \pm 0,1 \mathrm{~d}$ & $14,8 \pm 0,2 \mathrm{ce}$ & $15,7 \pm 0,1 \mathrm{~b}$ & $16 \pm 0,2 a b$ & $16,8 \pm 0,3 \mathrm{a}$ \\
\hline Légrés területe $\left(\mu \mathrm{m}^{2}\right)$ & $27,7 \pm 0,9$ a & $27,2 \pm 1,1 \mathrm{a}$ & $27,3 \pm 0,9$ a & $26,5 \pm 0,8$ a & $44,8 \pm 1,9 \mathrm{~b}$ \\
\hline $\begin{array}{l}\text { sztómaszám/levélterület a színi és } \\
\left.\text { fonáki oldalon együttesen ( } \mathrm{db} / \mathrm{mm}^{2}\right)\end{array}$ & $152,4 \pm 12,1 \mathrm{a}$ & $121 \pm 8,3 \mathrm{a}$ & $134,9 \pm 9,3$ a & $124,9 \pm 8,8 \mathrm{a}$ & $131,6 \pm 13,2 \mathrm{a}$ \\
\hline $\begin{array}{l}\text { légrésterület a levélterületre } \\
\text { vonazkoztatva }\left(\mu \mathrm{m}^{2} / \mathrm{mm}^{2}\right)\end{array}$ & $4229 \pm 337 \mathrm{ab}$ & $3297 \pm 226$ a & $3677 \pm 254$ a & $3312 \pm 233$ a & $5891 \pm 591 \mathrm{~b}$ \\
\hline $\begin{array}{l}\text { a színi és fonáki levélfelületen lévı } \\
\text { sztómák aránya }\end{array}$ & 3,27 & 2,24 & 2,06 & 2,19 & 2,57 \\
\hline
\end{tabular}




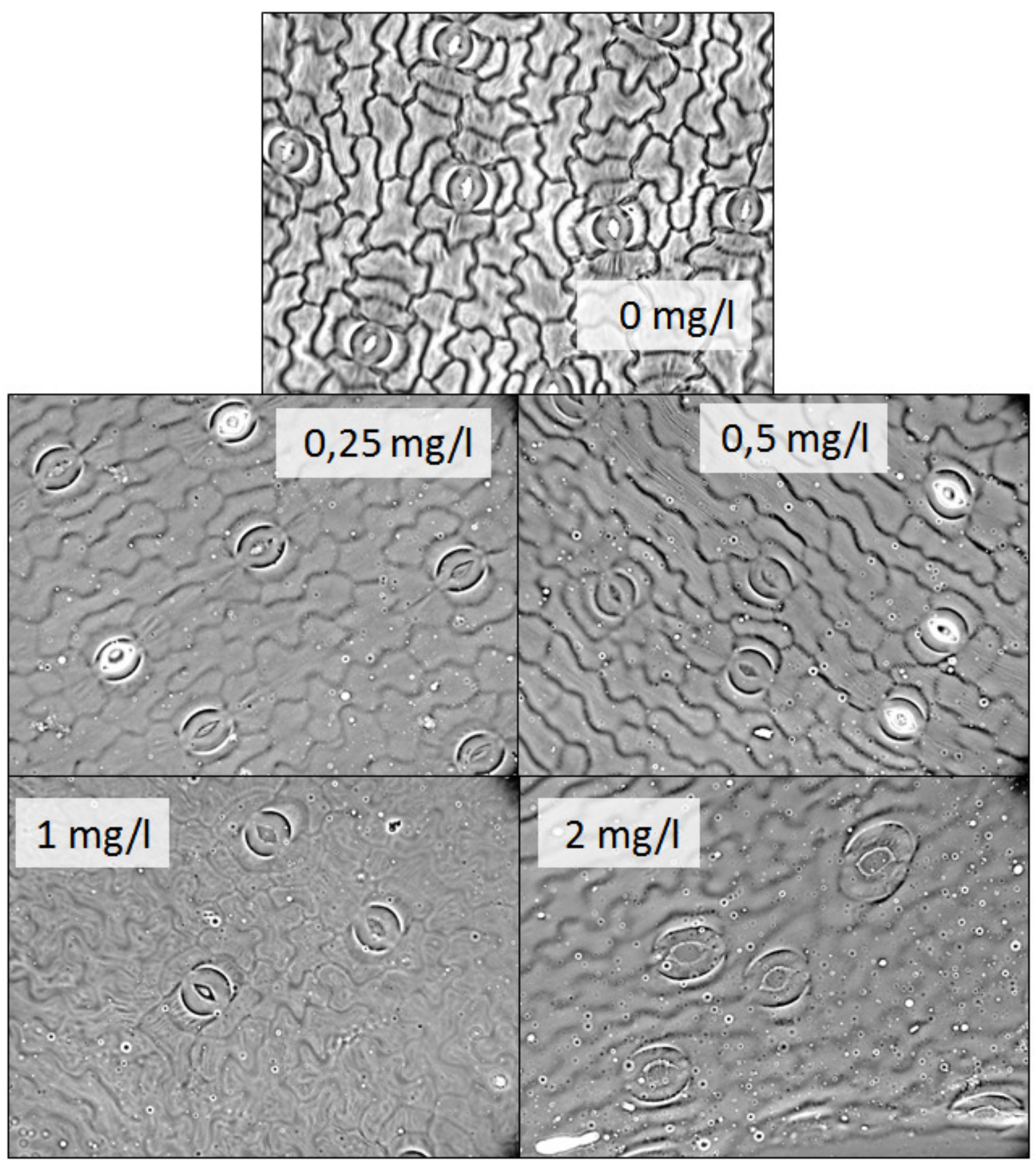

71. ábra. A PBZ-kezelések utóhatása Spathiphyllum floribundum 'Petite' sarjtenyészeténél a sztómák méretének alakulására.

A keresztmetszeteket vizsgálva megállapítható, hogy a kontrollnál a legnagyobb a levélvastagság, a PBZ koncentrációjának növekedésével ez az érték csökken. A kontrollnál és a legkisebb PBZ-koncentráció hatására a sejtek gömbölydedek, vakuolizáltak, magasabb PBZ koncentrációnál viszont kevésbé. Az intercelluláris járatok mérete szintén fordított arányban változik a PBZ alkalmazott koncentrációjával. A kontrollhoz képest a PBZ hatására a vaszkuláris elemek differenciáltabbá váltak. A mezofillum szerkezetében is változás figyelhető meg: a kontrollnál egysejtsoros a paliszádparenchima, a két alacsonyabb PBZ koncentráció esetén kétsejtsoros, magasabb koncentrációnál nem különíthetőek el (72. ábra). 

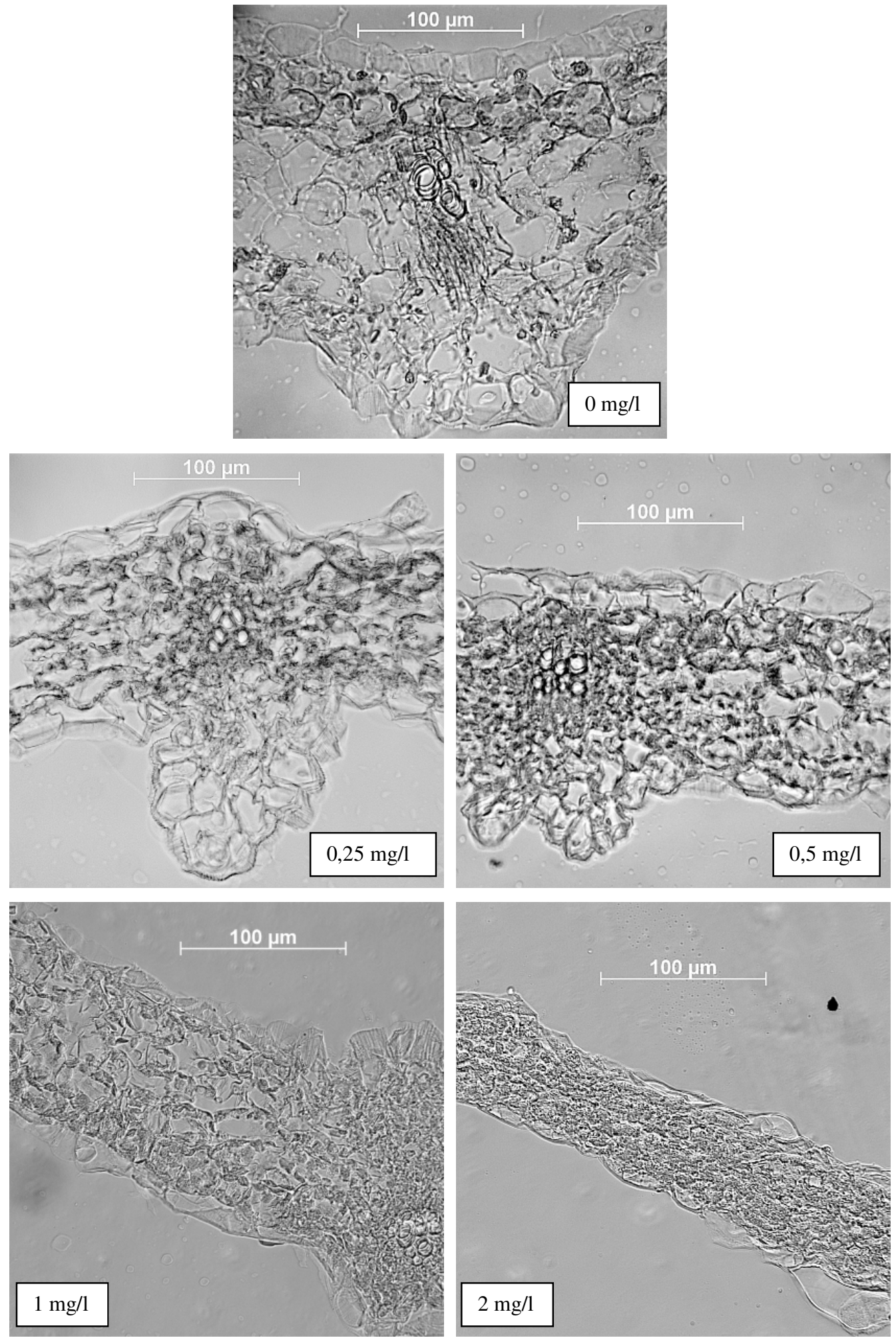

72. ábra. A PBZ-kezelések utóhatása Spathiphyllum floribundum 'Petite' sarjtenyészeténél a levélkeresztmetszeti anatómiai jellemzőkre. 40x-es nagyítású, fáziskontrasztosított fénymikroszkópos felvételek. 


\subsubsection{Klorofilltartalom, peroxidázaktivitás}

A klorofilltartalmat és a peroxidázaktivitást közvetlenül a PBZ-kezelések után mértem meg. A kontroll növények klorofillszintjével azonosnak találtam a 0,5 $\mathrm{mgL}^{-1} \mathrm{PBZ}$ kezelésben részesült növényekét, a többi PBZ-koncentráció esetében viszont kisebb értékeket mértem, a különbség szignifikáns volt. A klorofill $a / b$ arány azonban nem változott a kezelések hatására (73. ábra).

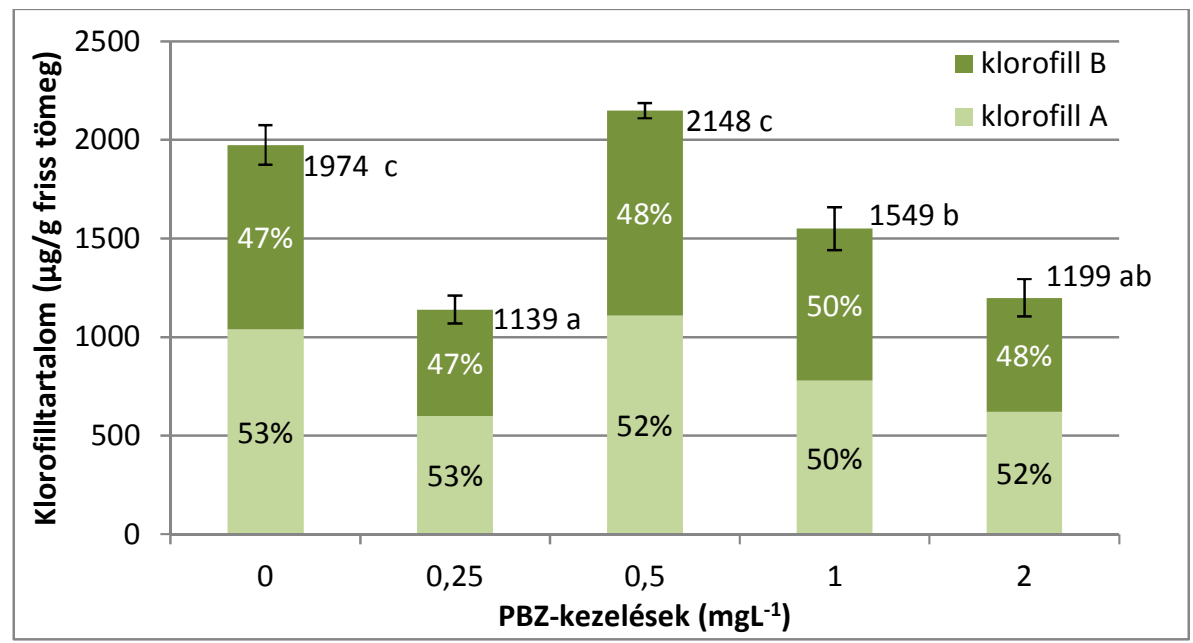

73. ábra. A PBZ-kezelések hatása Spathiphyllum floribundum 'Petite' sarjtenyészeténél a klorofilltartalom alakulására, Games-Howell teszt $(\mathbf{p}<0.05)$.

A növények peroxidázaktivitása megnőtt a kezelések hatására a kontrollhoz képest, a 0,5 $\mathrm{mgL}^{-1}$ PBZ-koncentráció esetében volt a legnagyobb, és csak ez az érték volt szignifikáns a kontrollhoz viszonyítva (74. ábra).

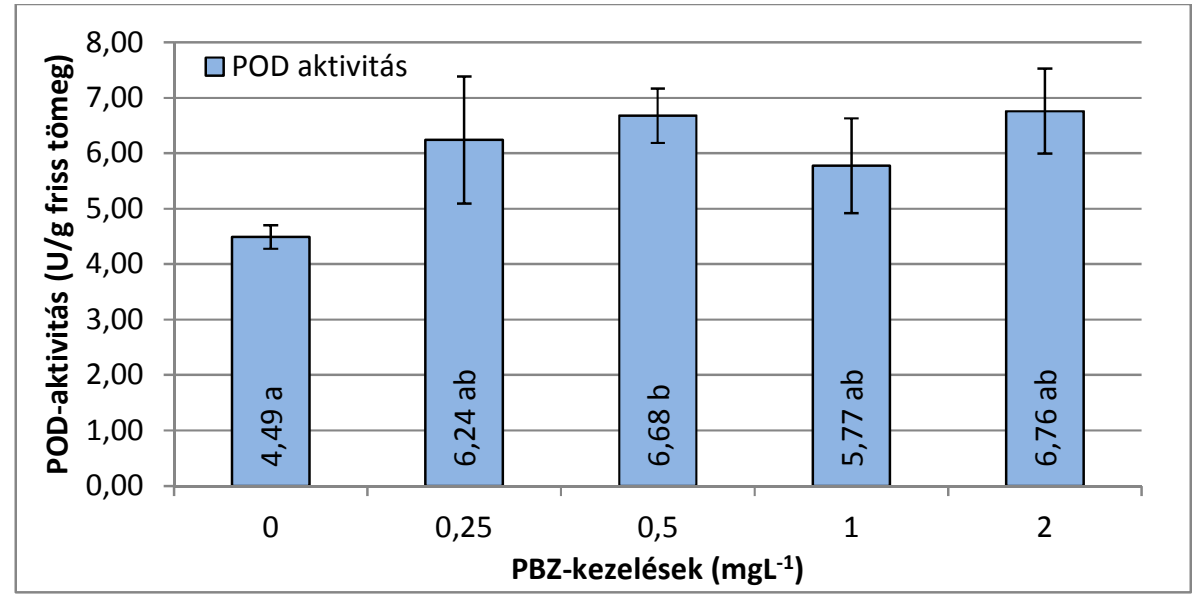

74. ábra. A PBZ-kezelések hatása Spathiphyllum floribundum 'Petite' sarjtenyészeténél a POD-aktivitás alakulására, Games-Howell teszt $(\mathbf{p}<0.05)$. 


\subsubsection{Akklimatizálás}

A PBZ-lal kezelt növények akklimatizálása sikerrel megtörtént, 8 hét letelte után a klímakamrában nevelkedő növények 100 \%-a életben maradt és fejlődésnek indult. Morfológiai különbségek nem mutatkoztak közöttük. Az akklimatizálás 4. hetében az újonnan fejlődő levelek részben vagy néhol egészben klorofillhiányosak voltak egyöntetüen mind a 4 kezelésböl származó növényeken (75. ábra), de ezeket a leveleket már normális levelek követték. A növényeket normál beltéri viszonyok mellett tartva 8 hónappal az akklimatizálás vége után jelentek meg rajtuk az első virágzatok, a PBZ kezelésektől függetlenül.

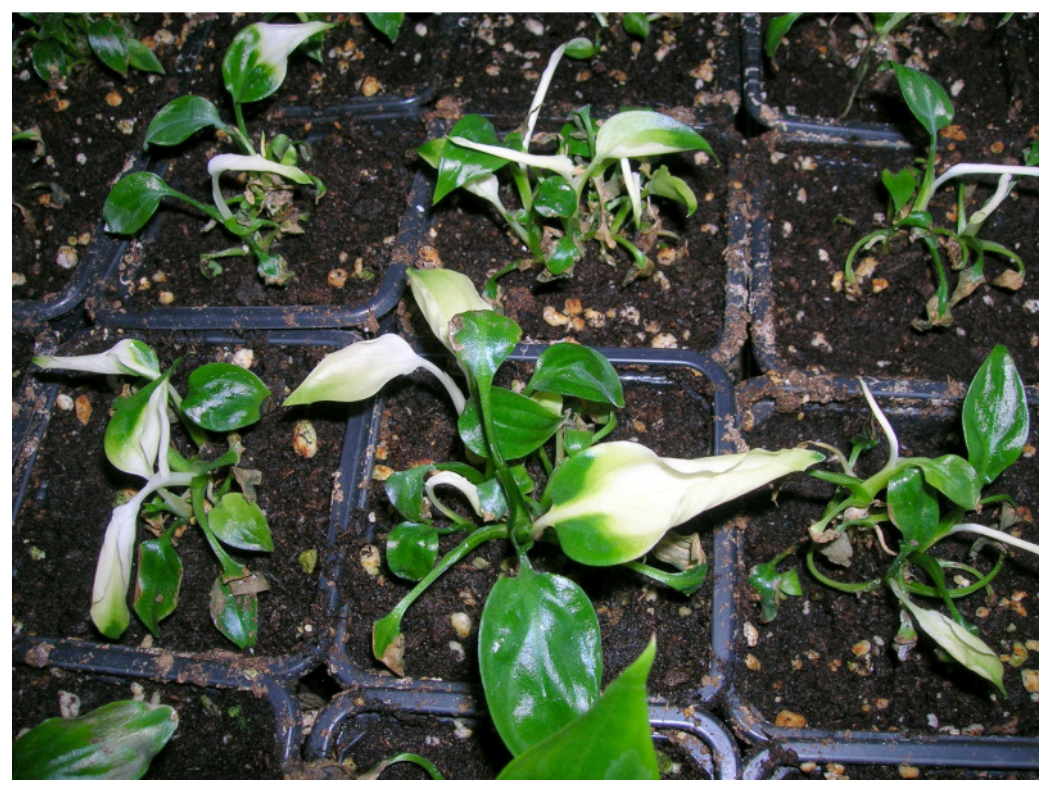

75. ábra Akklimatizálás során fejlődött klorofillhiányos, részlegesen albínó levelek Spathiphyllum floribundum 'Petite' fajtánál 9000 lx megvilágítás mellett 


\section{Következtetések}

\subsection{Kultúraindítás}

Az első két indítás sikertelensége az elégtelen sterilizálási eljárás miatt következett be. Ennél a két indításnál a fertőtlenítési procedúra nem tartalmazott higany(II)-kloridos fürdőt, ráadásul az anyanövények beszerzése nem sokkal az indítást megelőzően történt, így az előéletükről nem volt tudomásom. A harmadik indítás során HEGEDÜS (2005) fertőtlenítési protokollját felhasználva és módosítva végeztem a sterilizálást (benomil helyett Nystatin-t alkalmazva és bevezetve a higany(II)-kloridos áztatást) mellyel nagyban sikerült növelnem a sterilizálás hatékonyságát. Ugyanakkor a sikeres sterilizálás ellenére alacsony volt az explantátumok regenerációja, ez két dologra utalhat: vagy a felhasznált citokinin típusa, ill. koncentrációja alkalmatlan a regeneráció kiváltására, vagy az antibiotikum-kezelés növekedésgátlást idézett elő az explantátumban. Az ismételt indítások során ugyanezzel a citokinintípussal és koncentrációval $\left(3 \mathrm{mgL}^{-1} \mathrm{MT}\right)$, az antibiotikumkezelések elhagyása mellett sikerült regenerációt előidézni az explantátumokból, így a felhasznált antibiotikum-kezelések fitotoxicitása, növekedésgátlást előidéző hatása lehetnek a sikertelen regeneráció okai. Az antibiotikumok fitotoxikus hatása több tényező függvénye: az alkalmazott koncentráció mellett a növény genotípusa és a kezelésben részesülö növényi rész is meghatározó (GEORGE et al., 1993). Az általam is alkalmazott neomicin-szulfát használatával kapcsolatban már kis koncentrációban $(2-50 \mu \mathrm{l} / \mathrm{mg})$ is merültek fel fitotoxicitási problémák pl. Prunus avium (CORNU et MICHEL, 1987) vagy Nicotiana plumbaginifolia esetén (POLLOCK et al., 1983).

A kísérleteimben a fertőtlenítési eljárás az antibiotikumok nélkül is sikeres volt, így az antibiotikum-kezelés alkalmazása nem, vagy csak kellő körültekintéssel javasolható Spathiphyllum taxonok kultúraindítása során, a higany(II)-klorid használatát pedig szükségesnek ítélem meg.

\subsection{A GGb forma}

\subsubsection{A GGb-telepek szaporodási rátája}

A különféle kísérletekböl származó eredményeknél a GGb-telepek szaporodási sebességének összevetéséhez kiszámoltam azok átlagos szaporodási rátáját 2 hónapra vonatkoztatva, átlag $4 \mathrm{GGb} /$ telep kiindulási mennyiséggel számolva. A 12. táblázatból látszik, hogy a szaporításhoz az 1/2× MS makroelem koncentráció mellett a BA és a TDZ a legalkalmasabb citokinin típusok. A táptalaj állagát tekintve a szilárdított táptalajhoz képest a folyékony táptalaj sokkal nagyobb szaporodási rátát biztosít BA használata esetén. A folyékony táptalajon elérhető $3 \times$ körüli szaporodási rátát szilárd táptalajon is lehet biztosítani kis 
BA-koncentráció mellett is, ha annak hatását flurprimidollal katalizáljuk. A triazolok endogén citokinin-bioszintézis növelő hatása létező jelenség (ZHU et al., 2004). A triazol hatására azonban a telepek regenerációja nagyobb mértékü, így a GGb forma megtartásával történő szaporításhoz a legjobb a vizsgált esetek közül a folyékony $0,5 \times$ MS táptalaj, $20 \mathrm{gL}^{-1}$ szacharózzal, $0,2 \quad-\quad 0,5 \quad \mathrm{mgL}^{-1} \quad \mathrm{BA}$ vagy $0,05 \mathrm{mgL}^{-1} \quad \mathrm{TDZ}$ és $0,1 \mathrm{mgL}^{-1} \mathrm{NES}$ növekedésszabályozó-kombináció felhasználásával.

12. táblázat. A GGb-tenyészetek szaporodási rátájának és telepátmérőjének összevetése a különféle kísérletek hatására

\begin{tabular}{|c|c|c|c|c|c|c|c|c|c|}
\hline $\begin{array}{l}\text { táptalaj } \\
\text { alap }\end{array}$ & állag & $\begin{array}{c}\text { szacharóz } \\
\left(\mathrm{gL}^{-1}\right)\end{array}$ & $\begin{array}{c}\text { citokinin } \\
\left(\mathrm{mgL}^{-1}\right)\end{array}$ & $\begin{array}{l}\text { auxin } \\
\left(\mathrm{mgL}^{-1}\right)\end{array}$ & $\begin{array}{l}\text { egyéb } \\
\left(\mathrm{mgL}^{-1}\right)\end{array}$ & $\begin{array}{c}\text { eltelt } \\
\text { idő } \\
\text { (hónap) }\end{array}$ & $\begin{array}{l}\text { GGb szám } \\
\text { telepen } \\
\text { belül }(\mathrm{db})\end{array}$ & $\begin{array}{c}\text { GGb } \\
\text { telepátmérő } \\
(\mathrm{mm})\end{array}$ & $\begin{array}{c}\text { átlagos } \\
\text { szaporodási } \\
\text { ráta / } 2 \text { hónap }\end{array}$ \\
\hline $0,5 \times \mathrm{MS}$ & SZ & 20 & $0,25 \mathrm{BA}$ & $0-1,5$ NES & - & 6 & $5,8-8,6$ & $9,8-12,7$ & 1,07 \\
\hline $0,5 \times \mathrm{MS}$ & SZ & 0 & $0,5 \mathrm{BA}$ & 0,1 NES & - & 2 & 4,6 & 14,1 & 0,60 \\
\hline $1-2 \times M S$ & SZ & $20-40$ & $0,5 \mathrm{BA}$ & 0,1 NES & - & 2 & $3,5-4,8$ & $10,0-11,4$ & 0,15 \\
\hline $0,5 \times \mathrm{MS}$ & SZ & 20 & $0,2 \mathrm{mgL}^{-1} \mathrm{BA}$ & 0,1 NES & $0,05-0,5 \mathrm{FP}$ & 3 & $8,2-8,9$ & $15,2-15,8$ & 3,03 \\
\hline $0,5 \times \mathrm{MS}$ & $\mathrm{F}$ & 20 & $0,05-0,5 \mathrm{BA}$ & 0,1 NES & - & 2 & $4,6-9,3$ & $10,7-15,1$ & 2,95 \\
\hline $0,5 \times \mathrm{MS}$ & $\mathrm{F}$ & 20 & $0,05-0,5 \mathrm{BR}$ & $0,1 \mathrm{NES}$ & - & 2 & $3,7-4,4$ & $10,8-11,9$ & 0,05 \\
\hline $0,5 \times \mathrm{MS}$ & $\mathrm{F}$ & 20 & $0,05-0,5 \mathrm{MT}$ & 0,1 NES & - & 2 & $3,1-5,8$ & $12,8-14,4$ & 0,45 \\
\hline $0,5 \times \mathrm{MS}$ & $\mathrm{F}$ & 20 & $\begin{array}{c}0,05-0,5 \\
\text { TDZ }\end{array}$ & $0,1 \mathrm{NES}$ & - & 2 & $5,1-7,2$ & $14,6-16,8$ & 2,15 \\
\hline
\end{tabular}

MS - Murashige-Skoog táptalaj, MT - metatopolin, NES - naftilecetsav, SZ - szilárd táptalaj, TDZ - thidiazuron

\subsubsection{A GGb forma sarjjá alakulása}

Az 13. táblázatban összesítettem, hogy az elvégzett kísérletek során a GGb forma melyik kezelés hatására milyen mértékben regenerálódott sarjakká. Teljes regenerációs gátlást csak gibberellinsavas $\left(\mathrm{GA}_{3}\right)$ kezelés esetén figyeltem meg, ez egybevág OROSZ (2006) eredményeivel is, aki többféle auxin (NES) + gibberellinsav $\left(\mathrm{GA}_{3}\right)$ kombináció esetén is megfigyelte a sarjregeneráció gátlását. A hajtásregeneráció a rendszeresen nem passzált telepek esetében, ha a táptalaj nem tartalmaz gibberellinsavat, egy idő után bekövetkezik, de nem egyszerre, sokszor elhúzódóan. OROSZ (2006) felvetette, hogy mérethatárhoz kötött lehet a regeneráció, én azonban nem tapasztaltam erre utaló jelet, egyaránt megfigyeltem kis- és nagyméretü telepekből történő hajtásregenerációt is. Triazolok nélkül 7-36 \% között alakult a sarjregeneráció, triazolok használatával ennél jóval nagyobb értékeket is sikerült elérni, bár egyöntetüen, szinkron lejátszódó regenerációt nem sikerült eddig megvalósítani (13. táblázat). 
13. táblázat. A GGb forma regenerációs arányai a különböző kezelések hatására

\begin{tabular}{|c|c|c|c|c|c|c|c|c|c|}
\hline $\begin{array}{l}\text { táptalaj } \\
\text { alap }\end{array}$ & állag & $\begin{array}{c}\text { szacharóz } \\
\left(\mathrm{gL}^{-1}\right)\end{array}$ & $\begin{array}{c}\text { citokinin } \\
\left(\mathrm{mgL}^{-1}\right)\end{array}$ & $\begin{array}{l}\text { auxin } \\
\left(\mathrm{mgL}^{-1}\right)\end{array}$ & $\begin{array}{l}\text { egyéb } \\
\left(\mathrm{mgL}^{-1}\right)\end{array}$ & $\begin{array}{c}\text { eltelt } \\
\text { idő } \\
\text { (hónap) }\end{array}$ & $\begin{array}{l}\text { regenerálódni } \\
\text { kezdett GGb-t } \\
\text { tartalmazó } \\
\text { telepek } \\
\text { aránya (\%) }\end{array}$ & $\begin{array}{l}\text { regenerálódott } \\
\text { sarjat } \\
\text { tartalmazó } \\
\text { telepek aránya } \\
(\%)\end{array}$ & $\begin{array}{c}\text { regenerálódás } \\
\text { jeleit mutató } \\
\text { telepek } \\
\text { összesen (\%) }\end{array}$ \\
\hline $0,5 \times \mathrm{MS}$ & SZ & 20 & $0,25 \mathrm{BA}$ & 0 NES & - & 6 & 7,1 & 16,7 & 23,8 \\
\hline $0,5 \times \mathrm{MS}$ & SZ & 20 & $0,25 \mathrm{BA}$ & $0,5 \mathrm{NES}$ & - & 6 & 12,9 & 22,6 & 35,5 \\
\hline $0,5 \times M S$ & SZ & 20 & $0,25 \mathrm{BA}$ & 1 NES & - & 6 & 20,0 & 8,6 & 28,6 \\
\hline $0,5 \times \mathrm{MS}$ & $\mathrm{F}$ & 20 & $0,2 \mathrm{BA}$ & $0,1 \mathrm{NES}$ & - & 2 & 17,1 & 8,6 & 25,7 \\
\hline $0,5 \times \mathrm{MS}$ & $\mathrm{F}$ & 20 & $0,2 \mathrm{BR}$ & $0,1 \mathrm{NES}$ & - & 2 & 4,9 & 2,4 & 7,3 \\
\hline $0,5 \times \mathrm{MS}$ & $\mathrm{F}$ & 20 & 0,05 TDZ & $0,1 \mathrm{NES}$ & - & 2 & 15,4 & 7,7 & 23,1 \\
\hline $0,5 \times \mathrm{MS}$ & $\mathrm{F}$ & 20 & 0,5 TDZ & 0,1 NES & - & 2 & 10,0 & 3,3 & 13,3 \\
\hline $1 \times \mathrm{MS}$ & SZ & 40 & $0,5 \mathrm{BA}$ & $0,1 \mathrm{NES}$ & - & 2 & 6,1 & 3,0 & 9,1 \\
\hline $0,5 \times \mathrm{MS}$ & SZ & 20 & $0,5 \mathrm{BA}$ & 0,1 NES & $3 \mathrm{GA}_{3}$ & 5 & 0 & 0 & 0 \\
\hline $0,5 \times \mathrm{MS}$ & SZ & 20 & $0,2 \mathrm{BA}$ & $0,1 \mathrm{NES}$ & 0,5 PBZ & 6 & $\mathrm{n} / \mathrm{a}$ & 100,0 & 100,0 \\
\hline $0,5 \times \mathrm{MS}$ & SZ & 20 & - & - & 0,25 PBZ & 3 & 13,0 & 15,2 & 28,2 \\
\hline $0,5 \times \mathrm{MS}$ & SZ & 20 & - & - & 0,5 PBZ & 3 & 4,4 & 4,4 & 8,8 \\
\hline $0,5 \times \mathrm{MS}$ & SZ & 20 & $0,5 \mathrm{BA}$ & $0,1 \mathrm{NES}$ & k 0,05 FP & 5 & $\mathrm{n} / \mathrm{a}$ & 36,0 & minimum 36,0 \\
\hline $0,5 \times M S$ & SZ & 20 & $0,5 \mathrm{BA}$ & $0,1 \mathrm{NES}$ & k 0,1 FP & 5 & $\mathrm{n} / \mathrm{a}$ & 50,0 & minimum 50,0 \\
\hline $0,5 \times \mathrm{MS}$ & SZ & 20 & $0,5 \mathrm{BA}$ & $0,1 \mathrm{NES}$ & k 0,2 FP & 5 & $\mathrm{n} / \mathrm{a}$ & 53,8 & minimum 53,8 \\
\hline $0,5 \times M S$ & SZ & 20 & $0,5 \mathrm{BA}$ & $0,1 \mathrm{NES}$ & k 0,5 FP & 5 & $\mathrm{n} / \mathrm{a}$ & 27,8 & minimum 27,8 \\
\hline
\end{tabular}

FP - flurprimidol, $\mathrm{GA}_{3}$ - gibberellinsav, $\mathrm{k}$ - a jelzett anyag utóhatása, MS - Murashige-Skoog táptalaj, n/a - nincs (nem elérhető) adat, NES - naftilecetsav, PBZ - paklobutrazol, SZ - szilárd táptalaj, TDZ - thidiazuron

A sarjjá történő regeneráció során a GGb-telepek nagy POD-aktivitása mindig kisebb szintre csökken, a GGb-telepek és sarjak POD-aktivitás szintje között egy nagyságrendbeli eltérés van. A hajtásregeneráció mindegyik kezelés esetében hasonlóan zajlott le.

\subsubsection{A GGb forma mibenléte}

A GGb forma kialakulása minden esetben a virágtorzsán történik, generatív fázisban lévő növényen, föleg in vitro körülmények között hormonhatásra, de előfordulását megfigyeltem in vivo is, külső hatás nélkül. In vitro (vegetatív állapotú) hajtástenyészetekből nem tudtam megfigyelni a kialakulásukat a vizsgált növekedésszabályozók, -retardánsok, emelt makroelemés szénhidrát-kombinációk alkalmazásával. Az irodalomban nem találtam erről szóló leírást az előzetesen ezzel a tenyészettel dolgozó kollégáim publikációin kívül. Az elektronmikroszkópos szövettani vizsgálatok szerint rügyszerü képletekről, törpehajtásokról van szó (SZALVA, 2003). Sarjjá regenerálódásuk, a rügyek „kihajtása” endogén módon gátolt lehet, annak ellenére, hogy nincsenek nyugalmi fázisban, hiszen in vitro körülmények között folyamatosan növekednek, szaporodnak. Spathiphyllum hibridek termesztése esetén a virágzás megindításához gyakorta használják a $\mathrm{GA}_{3}$-kezelést, aminek hatására generatív fázisba kerül a növény. Nem közvetlenül a $\mathrm{GA}_{3}$-szint emelkedése váltja ki a virágzást, hanem a kapcsolt folyamatok. A $\mathrm{GA}_{3}$-szint 
megemelkedése oxidatív stresszt okoz, és erre válaszként aktiválódik a $\gamma$-glutamilcisztein-szintetáz, megnő a glutation-szintézis. Az oxidatív stressz megemelkedése jól mérhető, a virágzásindukált és virágzó növények összes peroxidáz-aktivitása nagyobb, mint a nem virágzóké (DEWIR et al, 2007). A GGb-telepek a méréseim szerint egy nagyságrenddel nagyobb POD-aktivitással jellemezhetők, mint a vegetatív fázisú sarjak. A virágtorzsáról leválasztott GGb-telepekben folyamatosan osztás és passzálás mellett, vagy hosszabb ideig $\mathrm{GA}_{3}$-tartalmú táptalajon tartva gátolt a sarjregeneráció, a GGb-telepek megőrzik formájukat, és a nagy POD-aktivitásukat. $\mathrm{GA}_{3}$ nélküli táptalajon hosszabb ideig nem osztva a tenyészeteket, elindul a regeneráció. A gibberellin-bioszintézist gátló anyagok hatékonyan csökkentik a GGbtelepek POD-aktivitását és serkentik a sarjjá alakulás folyamatát. Ezek alapján a GGb forma egy generatív fázisban lévő törpe hajtáskezdeménynek tekinthető, melyben endogén gátlás következtében nincs megnyúlás. Az endogén gátlás kialakításában és fenntartásában az adatok és eredmények alapján a gibberellineknek van szerepe. A gibberellinbioszintézis-gátló triazolok hatására azonban a GGb telepek könnyebben kerülnek vissza vegetatív fázisba, amit mutat a sarjjá regenerálódás nagyobb mértéke, és a biokémiai jellemzők közül a POD-aktivitás egyértelmü és nagymértékü csökkenése.

\subsection{A szénhidráttípusok hatása a sarjtenyészetre}

A különböző szénhidrátok hatását vizsgálva a sarjtenyészetek fejlődésére megállapítható, hogy 2 w/v\% koncentrációban a monoszacharidok, - a fruktóz valamint a glükóz -, jobb hatással vannak a növények fejlődésére, mint a szacharóz, a maltóz használata viszont a többi szénhidrátforráshoz képest kifejezetten előnytelen. Az irodalmi források közül egy sem vizsgálta a szacharóztól eltérő szénhidrátok hatását a sarjtenyészetben. Eredményeim szerint a szacharóztól eltérő szénhidrátforrások (fruktóz, glükóz) is alkalmasak Spathiphyllum 'Petite' in vitro nevelése során, sőt, pozitív hatásokkal rendelkeznek. A nemredukáló diszacharid, a maltóz viszont nem ajánlható. $\mathrm{Az}$ általam mért nettó $\mathrm{CO}_{2}$-asszimilációs ráta értékek $20 \mathrm{gL}^{-1}(2 \%)$ szacharóz mellett egy nagyságrenddel nagyobbak, mint a $30 \mathrm{gL}^{-1}(3 \%)$ vagy $60 \mathrm{gL}^{-1}$ (6 \%) szacharóz esetén mérhető értékek 'Petite' fajtánál VAN HUYLENBROECK et DEBERGH (1996) eredményeihez képest, akik FONNESBECH et FONNESBECH (1979) protokollja alapján nevelték in vitro a növényeket $2 \mathrm{mgL}^{-1} \mathrm{PBA}$ citokinin mellett. A magasabb (és egyébként pozitív) nettó $\mathrm{CO}_{2}$-asszimilációs ráta a növények könnyebb akklimatizálhatóságát is magával vonja (KUBOTA, 2001).

A szaporodási rátákat tekintve az irodalmi források eredményei egymás közt (2. táblázat) illetve az általam kapott szaporulati rátával nem közvetlenül összevethetőek, mert amellett, hogy csak $3 \%$-os koncentrációban alkalmaztak szacharózt, más hormonszintekkel is dolgoztak; 
leggyakrabban 1-2 $\mathrm{mgL}^{-1}(\sim 4-8 \mu \mathrm{M})$ BA felhasználásával, míg én kisebb, 0,5 mgL $\mathrm{m}^{-1}$-es koncentrációban alkalmaztam a citokinint. Az eltérö időtartam alatt mért szaporulati ráta is nehezen egységesíthető, mert, ahogy megmutattam, nem lineárisan változnak az egyes paraméterek az idő függvényében. A szerzők túlnyomó többsége 1-2 mgL ${ }^{-1}$ BA-t használ a szaporításra, mely azonban sokkal inkább lecsökkenti a növények méretét, mint az általam alkalmazott $0,5 \mathrm{mgL}^{-1}$ koncentráció. A kevésbé rejuvenilizálódott növényeknek viszont kevesebb időre van szüksége az akklimatizálódáshoz. Tehát csak az újonnan fejlődött sarjak abszolút mennyisége alapján még nem értékelhető egy szaporítási technológia, hiszen ezen sarjak egyéb paraméterei (magasság, tömeg - amiket sok forrás nem közölt) nagyban befolyásolják, hogy a felszaporítási szakaszt követően mennyi idő alatt nevelhető az adott állományból akklimatizált növény.

\subsection{A paklobutrazol hatása a sarjakra}

Bár egyes források szerint a paklobutrazol képes növelni a növények endogén citokininszintjét (ZHU et al., 2004), ez nem nyilvánult meg a kísérlet során a sarjszámnövekedés szempontjából. A növekedésgátlás viszont erőteljesen látszódott a növénymagasságokat vizsgálva a kezelés után. A kezelt növények magassága PBZ-mentes táptalajon 50 nap után kezdett normalizálódni, a két kisebb koncentrációjú PBZ-kezelés után a növények levél- és gyökérszáma szignifikánsan meghaladta a nagyobb koncentrációjú PBZ-kezeléseknél mérhető értékeket. A legnagyobb, $2 \mathrm{mgL}^{-1} \mathrm{PBZ}$ koncentráció utóhatásvizsgálata során a sarjcsomók tömege elérte a kontroll szintjét, de a magasságuk nem. Ez fokozott asszimiláta-felhalmozásra utalna, de sem a szárazanyag-tartalom, sem a fotoszintetikus ráta nem ezt mutatja. Ehelyett nagy valószínüséggel a növényben felhalmozódó víz járul hozzá a tömegnövekedéshez. A nagy turgor így szélesre nyitott sztómákat eredményez.

A nagy PBZ-koncentráció mellett mért nagyobb sztómanyitottságot magyarázhatná még, hogy a PBZ képes növelni a növényi szövetek endogén citokininszintjét (ZHU et al., 2004), valamint az IES koncentrációját is (NAGY et al, 1991, ZHENG et al, 2012). Mind a citokininek (WANG et al., 1994), de különösen az IES nagy mértékben hatással van a sztómanyitódásra (PEMADASA, 1982; COUSSON, 2010). Azonban a fokozott endogén citokininszintézisre utaló jelet nem tapasztaltam, valamint a megemelkedett POD-aktivitás nem a nagyobb, hanem inkább a kisebb IES-szintet segítheti elö, mert az IES-oxidáz aktivitás kizárólag a peroxidázoknak tulajdonítható (SHINSHI et NOGUCHI, 1975).

A paklobutrazol a többi triazolhoz hasonlóan egyes növényeknél növelheti az abszcizinsav koncentrációját (ASARE-BOAMAH et al, 1986; UPRETI et al., 2013), ám néhány esetben csökkenti (WANG et al, 1987; BUTA et SPAULDING, 1991). Az abszcizinsavnak nagy 
szerepe van a sztómazáródás indukálásában (LIOTENBERG et al, 1999), és ezáltal a transzspiráció csökkentésében. In vitro növényeknél azonban az abszcizinsav nem minden esetben vált ki sztómazáródási reakciót (BRAINERD and FUCHIGAMI, 1982; WARDLE et SHORT, 1983), az in vitro fejlődött sztómák szerkezeti eltérései miatt (ZEIGER, 1983). HAZARIKA et al. (2002) szerint Citrus féléken a PBZ in vitro táptalajba adagolva csökkentette a sztómanyíltságot, én ennek az ellenkezőjét tapasztaltam Spathiphyllum esetén: $2 \mathrm{mgL}^{-1}$ koncentrációban jelentősen növelte a sztómák nyitottságát, ugyanakkor a transzspiráció jóval kisebb lett. Az eredmények alapján a PBZ által kiváltott in vitro transzspiráció-csökkenés nem kizárólag az abszcizinsavhoz kötött sztómaregulációval valósul meg. A nyitott sztómák melletti kisebb transzspiráció magyarázata lehet, hogy valamilyen okból kifolyólag akadályozott a víz leadása a sejtekből az intercelluláris járatokba, ahonnan kikerülhet a vízgőz a sztómán keresztül. Eredményeim azt mutatják, hogy a keresztmetszeti felvételeknél a nagy, $2 \mathrm{mgL}^{-1} \mathrm{PBZ}$ koncentráció esetén a többi kezeléshez képest kisebbek voltak az intercelluláris járatok, másrészt irodalmi adatok szerint a PBZ hatására megváltozik a sejtfalak poliszacharid összetétele (WANG et al., 1986), ami a vízvisszatartásban játszhat szerepet. TARI (2003) eredményei szerint a PBZlal kezelt babnál egységnyi felületre vetítve nem kisebb a transzspiráció, és a kezelt növényeknél a transzspiráció-csökkenés csak abból adódik, hogy kisebb volt a levélfelület. A Spathiphyllum esetében mért adataim szerint a PBZ transzspiráció-csökkentő hatása egységnyi felületre vetítve is érvényesül.

A klorofilltartalom nem közvetlenül jelzi a növény fotoszintetikus kapacitását, de jó indikátora a fotoszintetikus rendszer általános állapotának (SÁEZ et al, 2012). A klorofill $a / b$ arány jellemző a különböző fényviszonyú élőhelyeken található növényekre (MELIS, 1991), a magas fényellátottság mellett fejlődő növényeknél ez az arány elérheti a 4-et is (LARSSON 1987), alacsony fényellátottság mellett az arány is alacsonyabb (PATTANAYAK et al, 2005). A kísérlet eredményei szerint az alacsony fényintenzitást igénylő és amellett nevelt Spathiphyllum floribundum 'Petite' ennek megfelelően alacsony (1 körüli) klorofill $a / b$ arányt mutatott, amit a paklobutrazol kezelés sem befolyásolt számottevően. Bár több szerző szerint a szer növeli a klorofilltartalmat más növényeknél (ABDUL JALEEL et al, 2007; BAÑóN et al, 2002), ez in vitro felhasználás esetén nem nyilvánult meg Spathiphyllum floribundum 'Petite' esetében, sőt, a 0,5 $\mathrm{mgL}^{-1}$ koncentrációt kivéve a többi esetben némileg csökkent a klorofilltartalom a kontrollhoz képest.

Az abiotikus stresszhatások (pl. szárazság, levegőhiány a gyökereknél, sókoncentráció) oxidatív mikrokörnyezet kialakulásához vezetnek a sejten belül, ami ellen védelmet a növények antioxidáns rendszere jelent (BAŤKOVÁ et al., 2008). Az antioxidáns-kapacitás megnövelése révén a szabadgyökök eliminálása könnyebb (KRAUS et al, 1995). E rendszer részei a peroxidáz 
enzimek. A gibberellinbioszintézis-gátlók növelik a POD-aktivitást (BAGATHARIA et CHANDA, 1998), melyek hozzájárulnak a megnövekedett antioxidáns-kapacitáshoz is. A paklobutrazol POD-aktivitás növelő tulajdonságát a sarjtenyészet esetén vizsgálatom is alátámasztotta, vagyis a PBZ-kezelések javíthatják a sarjnövények stressztoleranciáját.

A paklobutrazolos kezelést követően az akklimatizálás közben a növényeken fejlődő klorofillhiányos, részlegesen klorotikus levelek nem a szer hatására alakultak ki, ehhez hasonló jelenséget ugyanis WERBROUCK et al. (1995) is leírnak tavaszi akklimatizálás során, mint a Spathiphyllum taxonoknál jelentkező akklimatizálási problémát. Az akklimatizáláshoz HUYLENBROECK et al. (1995) Spathiphyllum 'Petite' fajtát vizsgálva nem javasolnak 100 $\mu \mathrm{mm}^{-2} \mathrm{~s}^{-1}$-nál magasabb megvilágítást, az ugyanis hirtelen kitettség esetén - hasonlóan más árnyéki növényekhez - fotoinhibíciót és a klorofill fotooxidációját okozza.

\subsection{A gyakorlat számára hasznosítható eredmények}

A Spathiphyllum fajták mikroszaporítása során a GGb forma alkalmazása nagyon előnyös lehet a folyamatosan bemerített folyadékkultúrás bioreaktoros rendszerekben, mert nem kell külön távtartót alkalmazni a levegőztetés megoldásához, és ár-apály rendszert sem kell alkalmazni, mint ahogy azt sarjak esetében tették (WATAD et al., 1997; DEWIR et al., 2006). A GGb formának a túléléshez és szaporodáshoz elegendő, ha a közeg folyamatos mozgásban van.

A GGb-telepek lassabb anyagcseréje következtében ez a forma alkalmas hosszú távú, génbanki tenyészetmegőrzéshez lassan növekedő tenyészet formájában, ún. minimális növekedési technika (minimal growth technique) alkalmazásával.

A GGb-telepek nedves környezetben lombikon kívül is hónapokig életképesek (a dolgozatban részletesen nem tárgyalt megfigyeléseim alapján), így megfelelő regenerációs technológia rendelkezésre állása esetén akklimatizálás nélküli szaporítóanyagként is felhasználhatók, egyfajta szintetikus magként. 


\section{6 Új tudományos eredmények}

1) Megállapítottam, hogy a Spathiphyllum floribundum 'Petite' GGb telepei alkalmasak folyamatosan bemerített folyadékkultúrás tenyésztésre, és ennek következtében nagyléptékü bioreaktoros tenyésztési rendszerben való szaporításra is.

2) Megállapítottam, hogy a GGB forma lassabb anyagcserével és fejlődéssel rendelkezik, mint a sarjtenyészetek, ezért ennek következtében alkalmas hosszú távú génbanki tenyészetfenntartásra is minimális növekedési technika alkalmazásával.

3) Kimutattam, hogy a Spathiphyllum floribundum 'Petite' in vitro sarjtenyészete a táptalajban jelen lévő szénhidrátforrások mellett is pozitív nettó $\mathrm{CO}_{2}$-asszimilációs rátával jellemezhető már a táptalajra helyezés után is.

4) A paklobutrazol transzspiráció-csökkentő hatásának mechanizmusához korábban nem ismert adatokat szolgáltattam: $2 \mathrm{mgL}^{-1}$ koncentrációban alkalmazva nyitottabb sztómákat eredményez, ennek ellenére magas turgort és vízvisszatartást okoz in vitro nevelt Spathiphyllum floribundum 'Petite' esetében, tehát az általa kiváltott transzspirációcsökkenés nem kizárólag az abszcizinsavhoz kötött sztómaregulációval valósul meg.

5) Megállapítottam, hogy a Spathiphyllum floribundum 'Petite' sarjainak és GGb-telepeinek POD-aktivitása között nagyságrendbeli eltérés van, a GGb forma POD-aktivitása magasabb, mint a sarjaké. A GGb-telepek POD-aktivitását a vizsgált triazolok (paklobutrazol és flurprimidol) hatékonyan csökkenteni képesek, és fejlődési irányukat módosítják.

6) A vizsgált triazolok (paklobutrazol, flurprimidol) növekedésszabályozó hatása nem kizárólag a növekedésretardáló hatásban nyilvánul meg; citokininnel együtt alkalmazva segítik Spathiphyllum floribundum 'Petite' esetén a GGb forma sarjjá alakulását.

7) Végül megállapítottam, hogy a GGb forma Spathiphyllum taxonok esetében egy generatív fázisban kialakult törpehajtásnak tekinthető, ami a gibberellinekhez kapcsolható belső gátló tényezők miatt nem tud normális sarjjá fejlődni, mindaddig, amíg a gátlás fennáll. A gátlást a gibberellinbioszintézis-gátló triazolok feloldják, és vegetatív irányba módosítják a GGb fejlődését, hajtásregenerációt idézve elő. 


\section{7 Összefoglalás}

A Spathiphyllum hibridek nagy mennyiségben termesztett és nagy kereskedelmi forgalommal rendelkező, világszerte elterjedt, népszerü cserepes virágos dísznövények. In vitro szaporítástechnológiájuk fejlesztése ezért kiemelt jelentőségü a dísznövényágazatban mind a szaporítóanyag-előállítók, mind a termesztők számára. Dolgozatomban a Spathiphyllum floribundum cv 'Petite' in vitro szaporításával foglalkoztam, melynek során egy új regenerációs út leírását és gyakorlati alkalmazásának lehetőségeit vizsgáltam. A módszer alapja egy speciális szervi-szöveti képződmény, rügyszerü test (GGb - green globular bud), mely a vitorlavirágok virágtorzsáján alakul ki, illetve indukálható a képződése in vitro körülmények között.

A kísérleteim során ennek a GGb testnek a kialakítási, szaporítási és sarjjá regenerálási lehetőségeit és feltételeit vizsgáltam. Kultúraindítási kísérleteket végeztem virágtorzsáról és hajtásrügyekről, majd meglévő és újonnan fejlődött sarjtelepek és GGb-telepek felszaporítási lehetőségeit vizsgáltam szilárd és folyékony táptalajokon, különböző növekedésszabályozókombinációk, növekedési retardánsok, eltérő makroelem-koncentrációk és különböző típusú szénhidrátok felhasználásával, egyúttal vizsgálva a GGb-telepek hajtásregenerációjához szükséges körülményeket. A kísérletek értékelése során a növények morfológiai karakterisztikáit, fejlődési dinamikájukat, biokémiai paraméterként klorofilltartalmukat és peroxidázaktivitásukat, a környezetfiziológiai jellemzők közül pedig a fotoszintézis-aktivitásukra utaló gázcsere-paramétereiket (transzspiráció, $\mathrm{CO}_{2}$-sztómakonduktancia, nettó $\mathrm{CO}_{2}$ asszimilációs ráta) vettem alapul.

Eredményeim alapján megállapítottam, hogy a GGb forma kialakulása és kialakítása a növény generatív stádiumához kötött és virágtorzsán történik spontán, vagy in vitro körülmények között jól indukálható $3 \mathrm{mgL}^{-1}$ meta-topolin tartalmú táptalajokon. Felszaporításához a szilárd és a folyékony táptalajok egyaránt alkalmazhatók, a folyékony táptalajon gyorsabb fejlődéssel rendelkezik a GGb-telep. Anyagcseréjük és szaporodási rátájuk szilárd táptalajon lassabb, mint a hajtástenyészeteké, de folyékony táptalajon megközelíti a hajtástenyészetekkel elérhető értékeket. A szilárd táptalajon nevelésük így jó lehetőséget nyújt génbanki tároláshoz, minimális növekedési technika felhasználásával. Hajtássá regenerálódásuk aszinkron módon, spontán is bekövetkezik a felszaporításra használt citokinintartalmú táptalajokon. A gibberellintartalmú táptalajok gátolják a folyamatot, a gibberellin-bioszintézist gátló anyagok ellenben elősegítik a regenerációt. A GGb-telepek a hajtástelepeknél egy nagyságrenddel nagyobb POD-aktivitással rendelkeznek, melyet a gibberellin-bioszintézis gátló vegyületek hatékonyan csökkenteni képesek, és ezzel egyidejűleg a spontán hajtásregenerációnál nagyobb mértékü sarjjá fejlődést is elöidéznek. 
Hajtástenyészetekből történő GGb-előállítási kísérleteim során vizsgáltam a különböző makroelem- és szénhidrát-koncentrációk, növekedési retardánsként a paklobutrazol, valamint különböző szénhidráttípusok hatását. Ezeknél a kísérleteknél ugyan GGb-telepet nem sikerült elöállítani, de a következő megállapításokat tettem: a 'Petite' fajta in vitro sarjtenyészete a táptalajban jelen lévő szénhidrátforrások mellett is pozitív karbonegyensúllyal, azaz pozitív nettó $\mathrm{CO}_{2}$-asszimilációs rátával jellemezhető, ami a szintén Araceae családba tartozó Dieffenbachia fajoknál már ismert jelenség, azonban Spathiphyllum hibrideknél eddig még nem írták le. A paklobutrazollal kapcsolatban pedig megállapítottam, hogy az általa hajtástenyészeteken kiváltott transzspiráció-csökkenés nem kizárólag az abszcizinsavhoz kötött sztómareguláción keresztül valósul meg.

A GGb-ből gibberellin-bioszintézis gátlók alkalmazásával elérhető sarjregeneráció továbbfejlesztésével lehetőség nyílik a Spathiphyllum hibridek olyan organogenezis úton történő felszaporítására, amelyet folyékony táptalajon lehet végezni, bioreaktoros technológiát felhasználva. A regenerációs út lehet kétlépcsős, aminek az első fázisában a folyékony közegben a GGb-k felszaporítása történik, a sarjregeneráció és gyökeresítés pedig a második szakaszban szilárd táptalajon. De a felszaporítási szakasz után a GGb telepeket akár ex vitro körülmények között közvetlenül is lehetne akklimatizálni megfelelő technológia kifejlesztésével, egyfajta szintetikus magként kezelve őket. 


\section{Summary}

Spathiphyllum hybrids are word-widely distributed popular potted ornamental plants which are produced in a very large amount and have a great commercial value. The development of their in vitro propagation technology is therefore especially important in the ornamental plant industry both for the propagation material producers as well as for plant producers. My thesis deals with the in vitro propagation of Spathiphyllum floribundum cv. 'Petite' using a new regeneration method and its applicability in practice. It is based on a bud-like special organ form (GGb - green globular bud) which is formed in vivo on its own, or can be formed in vitro using plant growth regulators from floral spadices.

In the course of my experiments I evaluated the induction and development of these GGb forms, the possibilities and requirements of their propagation and regeneration to shoots. I carried out experiments to start sterile cultures from spadices and stem buds, and I examined the possibilities to multiply the newly developed and already existing GGb and shoot cultures using solid and liquid media supplemented with different type and concenration of plant growth regulators, growth retardants, macroelements and carbohydrates. I assessed the requirements of the GGb forms to regenerate into shoots. The evaluations of my experiments were based on morphological characteristics, developmental dynamics, biochemical parameters like chlorophyll content and peroxidase activity, and ecophysiological features which were characterised by the photosynthetic efficiency of the plants: transpiration, $\mathrm{CO}_{2}$ stomatal conductivity, net photosynthetic rate.

Based on my results I can assume that the formation or artificial induction of the GGb form is bound to the generative phase of the mother plant and occuring on the floral spadices spontaneously or can be induced in vitro on media containing $3 \mathrm{mgL}^{-1}$ metatopoline. The multiplication of this form can be done using agar solidified or completely unsolidified liquid medium, the latter enhances the development of new GGbs. Using solid medium the multiplication rate of the GGbs seems to be lower than that of shoot cultures because of their slower metabolism but liquid cultures bear nearly the same multiplication rate as shoot cultures. As GGbs have slow metabolism, solid media can be useful for in vitro storage using minimal growth technique. The regeneration of the GGbs to shoots occur spontaneously on media containing cytokinins used for multiplication but in an asynchronous way. Gibberellic acid inhibits the regeneration process completely while gibberellin antagonists enhance it. The peroxidase activity of the GGbs is greater with an order of magnitude than that of the shoot cultures. This higher peroxidase activity can be decreased efficiently by the application of gibberellin antagonists which also enhance the GGbs' regeneration to shoots. 
To examine the possibility of inducing GGbs from shoot tip cultures I have evaluated different compounds and concentration of macroelements, carbohydrates and growth retardants. Albeit GGb induction was not successful in these experiments, the following observations could be made: the shoot culture of cv. 'Petite' had positive carbon balance indicating positive net photosynthetic rate, despite the presence of carbohydrates in the culture medium. Another genus in the Araceae family, Dieffenbachia, was described with positive carbon balance under in vitro conditions but Spathiphyllum hybrids have not yet been described to show this feature. Another observation was made with paclobutrazol as growth retardant on shoot cultures: its ability to decrease transpiration is already known but my research unveiled that its mechanism of action is not connected with the stomatal regulation controlled by abscisic acid.

Optimizing the GGb-to-shoot regeneration using gibberellin antagonists would give a possibility to develop a new way in the micropropagation of Spathiphyllum hybrids, which uses an organogenic pathway bearing a relatively high genetic stability combined with bioreactor technology using liquid cultures which offers high multiplication rate. The regeneration process could be carried out in a two-step way, in which the first one uses liquid medium to multiply the $\mathrm{GGb}$ formation and the second one uses solid medium to regenerate the GGbs to shoots and elongate them. A more advanced, one-step way would be the direct acclimatization of the GGb formation as a kind of synthetic seed after a multiplication phase in a bioreactor system if a suitable regeneration method could be find using the appropriate type and concentration of gibberellin antagonist. 


\section{Irodalomjegyzék}

ABDUL JALEEL, C., MANIVANNAN, P., SANKAR, B., KISHOREKUMAR, A., SANKARI, S., PANNEERSELVAM, R. (2007): Paclobutrazol enhances photosynthesis and ajmalicine production in Catharanthus roseus. Process Biochem. 42, 1566-1570. DOI: http://dx.doi.org/10.1016/j.procbio.2007.08.006

ABO EL-NIL, M.M., ZETTLER, F.W. (1976): Callus initiation and organ differentiation from shoot tip cultures of Colocasia esculenta. Plant Sci. Lett. 6, 401-408. DOI: http://dx.doi.org/10.1016/0304-4211(76)90122-X

ACEVEDO-RODRÍGUEZ, P., STRONG, M.T. (2005): Monocotyledons and Gymnosperms of Puerto Rico and the Virgin Islands. Washington DC: National Museum of Natural History. $415 \mathrm{p}$.

ADELBERG, J.W., DELGADO, M.P., TOMKINS, J.P. (2005): Ancymidol and liquid media improve micropropagation of Hemerocallis hybrid cv. "Todd Monroe" on a thin-film rocker bioreactor. J. Hortic. Sci. Biotech. 80, 774-778.

AMAKI, W., HIGUCHI, H. (1992): A possible propagation system of Nephrolepis, Asplenium, Pteris, Adiantum and Rumohra (arachniodes) through tissue culture. Acta Hort. (ISHS) 300, 237-244.

AMOO, S.O., FINNIE, J.F., STADEN, J.V. (2011): The role of meta-topolins in alleviating micropropagation problems. Plant Growth Regul. 63, 197-206. DOI: http://dx.doi.org/ 10.1007/s10725-010-9504-7

AREMU, A.O., BAIRU, M.W., DOLEŽAL, K., FINNIE, J.F., STADEN, J.V. (2012): Topolins: A panacea to plant tissue culture challenges? Plant Cell Tiss. Org. Cult. 108, 1-16. DOI: http://dx.doi.org/10.1007/s11240-011-0007-7

ARNON, D.I. (1949): Copper enzymes in isolated chloroplasts. Polyphenoloxidase in Beta vulgaris. Plant Physiol. 24, 1-15. DOI: http://dx.doi.org/10.1104/pp.24.1.1

ASARE-BOAMAH, N.K., HOFSTRA, G., FLETCHER, R.A., DUMBROFF, E.B. (1986): Triadimefon protects bean plants from water stress through its effects on abscisic acid. Plant Cell Physiol. 27, 383-390.

BAGATHARIA, S.B., CHANDA, S.V. (1998): Changes in peroxidase and IAA oxidase activities during cell elongation in Phaseolus hypocotyls. Acta Physiol. Plant. 20, 9-13. DOI: http://dx.doi.org/10.1007/s11738-998-0037-X

BAIRU, M.W., KULKARNI, M.G., STREET, R.A., MULAUDZI, R.B., STADEN, J.V. (2009): Studies on seed germination, seedling growth, and in vitro shoot induction of Aloe ferox Mill., a commercially important species. HortScience 44, 751-756.

BAIRU, M.W., STIRK, W.A., DOLEŽAL, K., STADEN, J.V. (2007): Optimizing the micropropagation protocol for the endangered Aloe polyphylla: can meta-topolin and its derivatives serve as replacement for benzyladenine and zeatin? Plant Cell Tiss. Org. Cult. 90, 15-23. DOI: http://dx.doi.org/10.1007/s11240-007-9233-4 
BAIRU, M.W., STIRK, W.A., DOLEŽAL, K., STADEN, J. V. (2008): The role of topolins in micropropagation and somaclonal variation of banana cultivars "Williams" and "Grand Naine" (Musa spp. AAA). Plant Cell Tiss. Org. Cult. 95, 373-379. DOI: http://dx.doi.org/10.1007/s11240-008-9451-4

BAKER, R., BURGER, W. (1976): Key and commentary on the species of Spathiphyllum (Araceae) in Costa Rica, including S. silvicola, sp. nov. Phytologia 33, 447-454.

BANINASAB, B. (2009): Amelioration of chilling stress by paclobutrazol in watermelon seedlings. Sci. Hortic. 121, 144-148. DOI: http://dx.doi.org/10.1016/j.scienta.2009.01.028

BAÑóN, S., GONZÁlEZ, A., CANO, E.A., FRANCO, J.A., FERNÁNDEZ, J.A. (2002): Growth, development and colour response of potted Dianthus caryophyllus cv. Mondriaan to paclobutrazol treatment. Sci. Hortic. 94, 371-377. DOI: http://dx.doi.org/10.1016/S03044238(02)00005-5

BAŤKOVÁ, P., POSPÍŠILOVÁ, J., SYNKOVÁ, H. (2008): Production of reactive oxygen species and development of antioxidative systems during in vitro growth and ex vitro transfer. Biol. Plant. 52, 413-422. DOI: http://dx.doi.org/10.1007/s10535-008-0085-5

BEGUM, A.A., TAMAKI, M., TAHARA, M., KAKO, S. (1994): Somatic embryogenesis in Cymbidium through in vitro culture of inner tissue of protocorm-like bodies. J. Jpn. Soc. Hort. Sci. 63, 419-427.

BEROVA, M., ZLATEV, Z. (2000): Physiological response and yield of paclobutrazol treated tomato plants (Lycopersicon esculentum Mill.). Plant Growth Regul. 30, 117-123. DOI: http://dx.doi.org/10.1023/A:1006300326975

BERTRAND, A.M., ALBUERnE, M.A., FERnÁNDEZ, H., GONZÁlEZ, A., SÁNCHEZTAMÉS, R. (1999): In vitro organogenesis of Polypodium cambricum. Plant Cell Tiss. Org. Cult. 57, 65-69. DOI: http://dx.doi.org/10.1023/A:1006348628114

BEYTES, C., HAMRICK, D. (2003): Ball Redbook: Volume 2 Crop Production. Batavia, Illinois, USA: Ball Publishing. 724 p.

BIHUA, C. (2000): Studies on tissue culture and rapid propagation of Spathiphyllum "Xiangshui". Journal of Fujian College of Forestry 20, 273-275.

BOGAERT, I., VAN CAUTER, S., WERBROUCK, S.P.O. AND DOLEZAL, K. (2006): New aromatic cytokinins can make the difference. Acta Hort. (ISHS) 725, 265-270.

BOWN, D. (2010): Aroids: Plants of the Arum Family. Timber Press. 468 p.

BRAINERD, K.E., FUCHIGAMI, L.H. (1982): Stomatal functioning of in vitro and greenhouse apple leaves in darkness, mannitol, $\mathrm{ABA}$, and $\mathrm{CO}_{2}$. J. Exp. Bot. 33, 388-392. DOI: http://dx.doi.org/10.1093/jxb/33.3.388

BUNTING, G.S. (1960): A revision of Spathiphyllum (Araceae). Mem. New York Bot. Gard. 10, 1-53.

BURKHART, L.F., MEYER, M.M. Jr. (1991): The gibberellin synthesis inhibitors, ancymidol and flurprimidol, promote in vitro rooting of white pine microshoots. Plant Cell Rep. 10, 475-476. DOI: http://dx.doi.org/10.1007/BF00233818 
BUTA, J.G., SPAULDING, D.W. (1991): Effect of paclobutrazol on abscisic acid levels in wheat seedlings. J. Plant Growth Regul. 10, 59-61. DOI: http://dx.doi.org/10.1007/BF02279312

CAPELLE, S. C.; MOK, D. W. S.; KIRCHNER, S. C., MOK, M. C. (1983): Effects of TDZ on cytokinin autonomy and the metabolism of N6-(DELTA2-isopentenyl) [8-14C]adenosine in callus tissues of Phaseolus lunatus L. Plant Physiol. 73:796-802.

CARDONA, F. (2004): Synopsis of the genus Spathiphyllum (Araceae) in Colombia. Annals of the Missouri Botanical Garden 91, 448-456.

CHAMPAGNAT, M., MOREL, G. (1972): La culture in vitro des tissus de tubercules d'Ophrys. Compt. end. Acad. Sci. Paris. 274D, 3379-3380.

CHANDRA, S., BANDOPADHYAY, R., KUMAR, V., CHANDRA, R. (2010): Acclimatization of tissue cultured plantlets: from laboratory to land. Biotechnol. Lett. 32, 1199-1205. DOI: http://dx.doi.org/10.1007/s10529-010-0290-0

CHA-UM, S., PUTHEA, O., KIRDMANEE, C. (2009): An effective in vitro acclimatization using uniconazole treatments and ex-vitro adaptation of Phalaenopsis orchid. Sci. Hort. 121, 468-473. DOI: http://dx.doi.org/10.1016/j.scienta.2009.02.027

CHEN, J., HALL, D.E., LUCA, V.D. (2005): Effects of the growth retardant paclobutrazol on large-scale micropropagation of daylily (Hemerocallis spp.). In Vitro Cell. Dev. Bio. Plant 41, 58-62. DOI: http://dx.doi.org/10.1079/IVP2004595

CHEN, J., HENNY, R.J. (2006): Somaclonal variation: an important source for cultivar development of floriculture crops. In: TEIXEIRA DA SILVA J.A. (ed.) Floriculture, ornamental and plant biotechnology, Vol II: Advances and Topical Issues. Global Science Books, London. pp 244-253.

CHEN, J., HENNY, R.J. (2008): Role of micropropagation in the development of ornamental foliage plant industry. In: TEIXEIRA DA SILVA J.A. (ed.) Floriculture, ornamental and plant biotechnology, vol V. Global Science Books, London, pp. 206-218.

CHEN, J., HENNY, R.J., MCCONNELL, D.B., (2002a): Development of new foliage plant cultivars. ASHS Press, pp. 466-472.

CHEN, L.R., CHEN, J.T., CHANG, W.C. (2002b): Efficient propagation of protocorm-like bodies and plant regeneration from flower stalk explants of the sympodial orchid Epidendrum radicans. In Vitro Cell. Dev. Biol. Plant 38, 441-445. DOI: http://dx.doi.org/ $\underline{10.1079 / \mathrm{IVP} 2002315}$

CHEN, J., MCCONNELL, D.B., HENNY, R.J., EVERITT, K.C. (2003): Cultural guidelines for commercial production of interiorscape Spathiphyllum. University of Florida, IFAS Extension, publikációszám: \#ENH958. URL: http://edis.ifas.ufl.edu/ep161 (hozzáférve 2013.07.14-én).

CHEN, J.T., CHANG, W.C. (2000): Plant regeneration via embryo and shoot bud formation from flower-stalk explants of Oncidium 'Sweet Sugar'. Plant Cell Tiss. Org. Cult. 62, 95100. DOI: http://dx.doi.org/10.1023/A:1026591003553 
CHENG, L., PU, B.J., ZHOU, G.Y. (2001): The effects of physical and chemical factors on differentiation and growth of green globular bodies of Nephrolepis cordifolia. Journal of Tropical and Subtropical Botany 9, 142-148.

CHUGH, S., GUHA, S., RAO, I.U. (2009): Micropropagation of orchids: A review on the potential of different explants. Sci. Hort. 122, 507-520. DOI: http://dx.doi.org/10.1016/j.scienta.2009.07.016

COLLINS, K. (2009): Spathiphyllum. Horticulture Week 20-21.

CORNU, D., MICHEL, M.F. (1987): Bacteria contaminants in shoot cultures of Prunus avium L. choice and phytotoxicity of antibiotics. Acta Hort. (ISHS) 212, 83-86.

CORTIZO, M., DIEGO, N. DE, MONCALEÁN, P., ORDÁS, R.J. (2009): Micropropagation of adult Stone Pine (Pinus pinea L.). Trees 23, 835-842. DOI: http://dx.doi.org/10.1007/s00468-009-0325-0

COUSSON, A. (2010): Indolyl-3-butyric acid-induced Arabidopsis stomatal opening mediated by 3',5'-cyclic guanosine-monophosphate. Plant Physiol. Biochem. 48, 977-986. DOI: http://dx.doi.org/10.1016/j.plaphy.2010.09.007

CROAT, T.B. (1978): Flora of Barro Colorado Island. Stanford, Calif: Stanford University Press. 943 p.

DABSKI, M., KOZAK, D. (1997): Wpyw 2-iP i IAA na regeneracje pedow i korzeni Spathiphyllum cv. 'Svend Neilson' in vitro. Zeszyty Problemowe Postepow Nauk Rolniczych. 449, 43-48.

DANERT, S., HANELT, P., HELM, J., KRUSE, J., SCHULTZE-MOTEL, J. (1981): Urania Növényvilág Magasabbrendü növények II., 2. ed. Budapest: Gondolat Kiadó. 482 p.

DAS NEVES, H.J., PAIS, M.S.S. (1980): A new cytokinin from the fruits of Zantedeschia aethiopica. Tetrahedron Lett. 21, 4387-4390. DOI: http://dx.doi.org/10.1016/S00404039(00)77865-8

DAS, A., PAUL, A.K., CHAUDHURI, S. (2000): Micropropagation of Spathiphyllum wallisii an important ornamental plant. Horticultural Journal 13, 71-75.

DE DIEGO, N., MONTALBÁN, I.A. AND MONCALEÁN, P. (2010): In vitro regeneration of Pinus spp. adult trees: new method for obtaining clonal plants. Acta Hort. (ISHS) 865, 361365.

DEWIR, Y.H., CHAKRABARTY, D., ALI, M.B., HAHN, E.J., PAEK, K.Y. (2005): Effects of hydroponic solution EC, substrates, PPF and nutrient scheduling on growth and photosynthetic competence during acclimatization of micropropagated Spathiphyllum plantlets. Plant Growth Regul. 46, 241-251. DOI: http://dx.doi.org/10.1007/s10725-005$\underline{0161-1}$

DEWIR, Y.H., CHAKRABARTY, D., ALI, M.B., SINGH, N., HAHN, E.-J., PAEK, K.-Y. (2007): Influence of GA3, sucrose and solid medium/bioreactor culture on in vitro flowering of Spathiphyllum and association of glutathione metabolism. Plant Cell Tiss. Org. Cult. 90, 225-235. DOI: http://dx.doi.org/10.1007/s11240-007-9212-9 
DEWIR, Y.H., CHAKRABARTY, D., HAHN, E.J., PAEK, K.Y. (2006): A simple method for mass propagation of Spathiphyllum cannifolium using an airlift bioreactor. In Vitro Cell. Dev. Biol. Plant 42, 291-297. DOI: http://dx.doi.org/10.1079/IVP2006764

DINIZ, J.D.N., ALMEIDA, J.L., OLIVEIRA, A.B. DE, BEZERRA, A.M.E. (2008): Protocolo para desinfestação, multiplicação e enraizamento in vitro de Spathiphyllum wallisi. Revista Ciência Agronômica 39, 107-113.

DOBRÁNSZKI, J., JÁMBOR-BENCZÚR, E., REMÉNYI, M.L., MAGYAR-TÁBORI, K., HUDÁK, I., KISS, E., GALLI Z (2005): Effects of aromatic cytokinins on structural characteristics of leaves and their post-effects on subsequent shoot regeneration from in vitro apple leaves of 'Royal Gala'. Int. J. Hort. Sci. 1, 41-46.

DOBRÁNSZKI, J., MAGYAR-TÁBORI, K., JÁMBOR-BENCZÚR, E., et al. (2002): Effect of conditioning apple shoots with meta-topolin on the morphogenic activity of in vitro leaves. Acta Agron. Hung. 50, 117-126. DOI: http://dx.doi.org/10.1556/AAgr.50.2002.2.1

DUQUENNE, B., EECKHAUT, T., WERBROUCK, S., HUYLENBROECK, J.V., (2007): Effect of enzyme concentrations on protoplast isolation and protoplast culture of Spathiphyllum and Anthurium. Plant Cell Tiss. Org. Cult. 91, 165-173. DOI: http://dx.doi.org/10.1007/s11240-007-9226-3

EBRAHEM, K.S. (1985): Effect of paclobutrazol (PP333) and flurprimidol (EL500) on vegetative growth, fruit characteristics and storage of Golden Delicious and Red Delicious apple. MSc Thesis, Kansas State University.

EECKHAUT, T., DUQUENNE, B., LAKSMANAN, P. AND VAN HUYLENBROECK, J. (2009): Development of microcolonies in protoplast culture of Spathiphyllum wallisii. Acta Hort. (ISHS) 829, 51-54.

EECKHAUT, T., WERBROUCK, S., DENDAUW, J., BOCKSTAELE, E.V., DEBERGH, P. (2001): Induction of homozygous Spathiphyllum wallisii genotypes through gynogenesis. Plant Cell Tiss. Org. Cult. 67, 181-189. DOI: http://dx.doi.org/10.1023/A:1011902108132

EECKHAUT, T.G.R., WERBROUCK, S.P.O., LEUS, L.W.H., BOCKSTAELE, E.J.V., DEBERGH, P.C. (2004): Chemically Induced polyploidization in Spathiphyllum wallisii Regel through somatic embryogenesis. Plant Cell Tiss. Org. Cult. 78, 241-246. DOI: http://dx.doi.org/10.1023/B:TICU.0000025659.19232.04

ENCKE, F. (1987): Kalt und Warmhauspflanzen: Arten, Herkunft, Pflege und Vermehrung : ein Handbuch für Liefhaben und Fachleute. Stuttgart: Verlag Eugen Ulmer. 565 p.

FERNÁNDEZ, H., BERTRAND, A.M., SÁCHEZ-TAMÉS, R. (1996): Micropropagation and phase change in Blechnum spicant and Pteris ensiformis. Plant Cell Tiss. Org. Cult. 44, 261-265. DOI: http://dx.doi.org/10.1007/BF00048534

FLETCHER, R.A., GILlEY, A., SANKHLA, N., DAVIS, T.D. (2010): Triazoles as plant growth regulators and stress protectants. pp. 55-138. In: Janick, J. (Ed.), Horticultural Reviews. John Wiley \& Sons, Inc.

FONNESBECH, M., FONNESBECH, A. (1979): In vitro propagation of Spathiphyllum. Sci. Hort. 10, 21-25. DOI: http://dx.doi.org/10.1016/0304-4238(79)90065-7 
FUCHIGAMI, L.H.,CHENG, T.Y.,SOELDNER, A. (1981): Abaxial transpiration and water loss in aseptically cultured Plum. J. Am. Soc. Hortic. Sci. 106, 519-522.

FUJIWARA, K., KOZAI, T. (1995): Physical microenvironment and its effects. pp. 319-369. In: AITKEN-CHRISTIE, J., KOZAI, T., SMITH, M.A.L. (szerk.) Automation and environmental control in plant tissue culture. Dordrecht: Springer Netherlands.

FUJIWARA, K., KOZAI, T., WATANABE, I. (1987): Fundamental studies on environments in plant tissue culture vessels. Journal of Agricultural Meteorology 43, 21-30.

GAUSSOIN, R.E., BRANHAM, B.E., FLORE, J.A. (1997): Carbon dioxide exchange rate and chlorophyll content of turfgrasses treated with flurprimidol or mefluidide. J. Plant Growth Regul. 16, 73-78. DOI: http://dx.doi.org/10.1007/PL00006981

GENEYIKLI, E. (2009): Researches on micropropogation for bariş zambaği (Spathiphyllum) varieties. MSc. Thesis, Department Of Biotechnology, Institute Of Natural And Applied Sciences, University Of Çukurova, Turkey, p. 59.

GEORGE, E.F. (szerk.) (1993): Plant propagation by tissue culture. Part 1-2. Edington, Wilts, England: Exegetics Ltd. 1361 p.

GEORGE, E.F. (szerk.) (2008): Plant propagation by tissue culture. Part 1. Dordrecht, Netherlands: Springer. 514 p.

GILL, R., SAXENA, P.K. (1993): Somatic embryogenesis in Nicotiana tabacum L.: induction by thidiazuron of direct embryo differentiation from cultured leaf discs. Plant Cell Rep. 12, 154-159. DOI: http://dx.doi.org/10.1007/BF00239097

GOH, C.-J., NATHAN, M.J., KUMAR, P.P. (1995): Direct organogenesis and induction of morphogenic callus through thin section culture of Heliconia psittacorum. Sci. Hort. 62, 113-120. DOI: http://dx.doi.org/10.1016/0304-4238(94)00734-W

GOH, C.J., WONG, P.F. (1990): Micropropagation of the monopodial orchid hybrid Aranda Deborah using inflorescence explants. Sci. Hort. 44, 315-321. DOI: http://dx.doi.org/10.1016/0304-4238(90)90132-X

GROSSMAN, K. (1992): Plant growth retardants: their mode of action and benefit for physiological research. pp. 788-797. In: KARSSEN, CM. VAN LOON LC., VREUGDENHIL, D. (szerk.) Progress in plant growth regulation. Springer. 963 p.

GROUT, B.W.W. (1988): Photosynthesis of regenerated plantlets in vitro and the stresses of transplanting. Acta Hort. (ISHS) 230, 129-135.

GROUT, B.W.W., MILLAM, S. (1985): Photosynthetic development of micropropagated strawberry plantlets following transplanting. Annals of Botany 55, 129-131.

HAN, B.H., YAE, B.W. (2001): In vitro propagation of Spathiphyllum floribundum cv. Cupid. Korean Journal of Plant Tissue Culture 28(4), 209-213.

HARE, P.D., STADEN, J.V. (1994): Inhibitory effect of thidiazuron on the activity of cytokinin oxidase isolated from soybean callus. Plant Cell Physiol. 35, 1121-1125.

HAZARIKA, B.N. (2006): Morpho-physiological disorders in in vitro culture of plants. Sci. Hort. 108, 105-120. DOI: http://dx.doi.org/10.1016/j.scienta.2006.01.038 
HAZARIKA, B.N., PARTHASARATHY, V.A., NAGARAJU, V. (2002): Anatomical variation in Citrus leaves from in vitro and greenhouse plants: scanning electron microscopic studies. Indian J. Hort. 59, 243-246.

HDIDER, C., DESJARDINS, Y. (1995): Reduction of ribulose-1,5-bisphosphate carboxylase/oxygenase efficiency by the presence of sucrose during the tissue culture of strawberry plantlets. In Vitro Cell. Dev. Biol. Plant 31, 165-170. DOI: http://dx.doi.org/10.1007/BF02632014

HEEMERS, L., OYAERT, E., VAN LABEKE, M. C., VOLCKAERT, E., DEBERGH, P. (2003): Seasonal influence on vegetative growth and flower initiation of Spathiphyllum. S. Afr. J. Bot. 69, 129-134.

HEGEDÜS, Á. (2005): Vitorlavirág és egyéb lágyszárú dísz- és vízinövények a kontyvirág-félék családjából. In: JÁMBORNÉ, B.,E.; DOBRÁNSZKI, J.(eds.) Kertészeti növények mikroszaporítása, Budapest: Mezőgazda Kiadó. 324 p.

HEITZ, H. (1997): A zöld otthon. Budapest: Magyar Könyvklub Park Könykiadó. 384 p.

HENDRIKS, L., SCHARPF, H.C. (1988): Temperaturreaktionen von Spathiphyllum. Zierpflanzenbau 28(3), 100-102.

HENNY, R.J. (1981): Promotion of flowering in Spathiphyllum "Mauna Loa" with gibberellic acid. HortScience 16, 554-555.

HENNY, R.J. (1986). Spathiphyllum. p 382-383. In: A. Halevy (szerk.): Handbook of flowering, Vol. 5. Boca Raton, Florida: CRC Press inc.

HENNY, R.J. (1995): TDZ increases basal bud and shoot development in Spathiphyllum 'Petite'. Plant Growth Regul. Soc. am. Quart. 23, 13-16.

HENNY, R.J., CHEN, J. (2010): Cultivar development of ornamental foliage plants. pp. 245290. In: Janick, J. (Ed.): Plant Breeding Reviews. John Wiley \& Sons, Inc.

HERWIG, R. (1976): 201 indoor plants in colour. Guildford and London: Utterworth Press.

HERZ, M. (1976): Der Zimmergärtner. Amsterdam: Amsterdam Boek bv.

HIGUCHI, H., AMAKI, W. (1989): Effects of 6-benzylaminopurine on the organogenesis of Asplenium nidus L. through in vitro propagation. Sci. Hort. 37, 351-359. DOI: http://dx.doi.org/10.1016/0304-4238(89)90146-5

HIGUCHI, H., AMAKI, W., SUZUKI, S. (1987): In vitro propagation of Nephrolepis cordifolia Prsel. Sci. Hort. 32, 105-113. DOI: http://dx.doi.org/10.1016/0304-4238(87)90021-5

HORGAN, R., HEWETT, E.W., HORGAN, J.M., PURSE, J., WAREING, P.F. (1975): A new cytokinin from Populus X robusta. Phytochemistry 14, 1005-1008. DOI: http://dx.doi.org/10.1016/0031-9422(75)85176-4

HUANG, Z.Y. (2004): Study on tissue culture of Platycerium bifurcatum. J. Biol. 21, 22-24.

HUETTEMAN, C.A., PREECE, J.E., (1993): Thidiazuron: a potent cytokinin for woody plant tissue culture. Plant Cell Tiss. Org. Cult. 33, 105-119. DOI: http://dx.doi.org/10.1007/BF01983223

HUTCHINSON, M. J.; MURCH, S. J.; SAXENA, P. K. (1996): Morphoregulatory role of TDZ: evidence of the involvement of endogenous auxin in TDZ-induced somatic embryogenesis 
of geranium (Pelargonium $\times$ hortorum Bailey). J. Plant Physiol 149, 573-579. DOI: http://dx.doi.org/10.1016/S0176-1617(96)80336-1

ILAN, A., ZIV, M., HALEVY, A.H. (1995): Propagation and corm development of Brodiaea in liquid cultures. Sci. Hort. 63, 101-112. DOI: http://dx.doi.org/10.1016/0304$\underline{4238(95) 00785-\mathrm{R}}$

INTUWONG, O., SAGAWA, Y. (1973): Clonal propagation of Sarcanthine orchids by aseptic culture of inflorescence. Am. Orchid Soc. Bull. 42, 209-215.

ISHIBASHI, M., SONOIKE, K., WATANABE, A. (1997): The inhibition of photosynthesis alters exposure of bean leaves to various low levels of $\mathrm{CO}_{2}$. Plant Cell. Physiol. 38, 619624.

ISHII, Y., TAKAMURA, T., GOI, M., TANAKA, M. (1998): Callus induction and somatic embryogenesis of Phalaenopsis. Plant Cell Rep. 17, 446-450. DOI: http://dx.doi.org/10.1007/s002990050423

JÁMBOR-BENCZÚR, E.; CSILLAG, A.; MÁRTA-RIFFER, A.; CSIZMADIA, G. (1994): In vitro regeneration and propagation of Platycerium bifurcatum. Acta Agron. Hung. 43(1-2), 59-66.

JÁMBORNÉ BENCZÚR, E., DOBRÁNSZKI, J. (eds.), 2005. Kertészeti növények mikroszaporítása: in vitro növényklónozás. Budapest: Mezőgazda. 324 p.

JINSHU, C. (1989): The effects of some hormones on bud induction and propagation of Spathiphyllum sp. Chinese Bulletin of Botany 6(3), 161-165.

KAÇAR, Y.A., MAZMANOĞLU, M., MENDI, Y.Y., SERÇE, S., ÇETINER, S. (2005): The effect of cytokinin type and concentration on multiplication rate of Spathiphyllum (Fam. Araceae). Asian Journal of Plant Sciences 4, 401-404. DOI: http://dx.doi.org/10.3923/ajps.2005.401.404

KATO, Y. (1967): Physiological and morphogenetic studies of fern gametophytes and sporophytes in aseptic culture. Planta 77, 127-134. DOI: http://dx.doi.org/10.1007/BF00387449

KOCH, K.E. (1996): Carbohydrate-modulated gene expression in plants. Annu. Rev. Plant Phys. $47,509-540$.

KOVTUN, Y., DAIE, J. (1995): End product control of carbon metabolism in culture grown sugarbeet plants. Plant Physiol. 108, 1647-1657.

KOZAK, D. (2002): The effect of growth retardants on induction and development of Gloriosa rothschildiana O'brien tubers in vitro. Acta Hort. (ISHS) 570, 345-349.

KRAUS, T.E., MCKERSIE, B.D., FLETCHER, R.A. (1995): Paclobutrazol-induced tolerance of wheat leaves to paraquat may involve increased antioxidant enzyme activity. J. Plant Physiol. 145, 570-576. DOI: http://dx.doi.org/10.1016/S0176-1617(11)81790-6

KUBALÁKOVA M, STRNAD, M. (1992): The effects of aromatic cytokinins (populins) on micropropagation and regeneration of sugar beet in vitro. Biol. Plant. 34, 578-579. 
KUBOTA, C. (2001): Concepts and background of photoautotrophic micropropagation, pp. 325334. In: NORIYUKI MOROHOSHI, ATSUSHI KOMAMINE (szerk.): Molecular Breeding of Woody Plants. Elsevier. 404 p.

KUNISAKI, J.T. (1977): Tissue culture of tropical ornamental plants [Clonal propagation]. HortScience 12, 141-142.

LAKSHMANAN, P.S., EECKHAUT, T., VAN HUYLENBROECK, J., VAN BOCKSTAELE, E. (2012): Embryogenic callus formation from the petioles of Spathiphyllum wallisii. Acta Hort. (ISHS) 961, 231-234.

LANG, N.T., HANG, N.T. (2006): Using biotechnological approaches for Vanda orchid improvement. Omonrice 14, 140-143.

LARSSON, U.K., ANDERSON, J.M., ANDERSSON, B. (1987): Variations in the relative content of the peripheral and inner light-harvesting chlorophyll ab-protein complex (LHC II) subpopulations during thylakoid light adaptation and development. BBA - Bioenergetics 894, 69-75. DOI: http://dx.doi.org/10.1016/0005-2728(87)90213-1

LENTON, J.R., APPLEFORD, N.E.J., TEMPLE-SMITH, K.E. (1994): Growth retardant activity of paclobutrazol enantiomers in wheat seedlings. Plant Growth Regul. 15, 281-291. DOI: http://dx.doi.org/10.1007/BF00029901

LIAO, F., WANG, B., XU, F., YANG, Z., WANG, G. (2006): Growth and physiological characteristics of plantlets of Spathiphyllum "Sensation" in rooting phase as affected by sucrose-free medium and diffusive ventilation. Acta Hort. (ISHS) 725, 325-332.

LIAO, Y.K., WU, Y.H. (2011): In vitro propagation of Platycerium bifurcatum (Cav.) C. Chr. via green globular body initiation. Botanical Studies 52, 455-463.

LIN, K.-H.R., TSOU, C.-C., HWANG, S.-Y., CHEN, L.-F.O., LO, H.-F. (2006): Paclobutrazol pre-treatment enhanced flooding tolerance of sweet potato. J. Plant Physiol. 163, 750-760. DOI: http://dx.doi.org/10.1016/j.jplph.2005.07.008

LIOTENBERG, S., NORTH, H., MARION-POLL, A. (1999): Molecular biology and regulation of abscisic acid biosynthesis in plants. Plant Physiol. Biochem. 37, 341-350. DOI: http://dx.doi.org/10.1016/S0981-9428(99)80040-0

LIU, T.H.A., KUO, S.S., WU, R.Y. (2001): Mass propagation of orchid protocorm-like bodies using air-driven periodic immersion bioreactor. Acta Hort. (ISHS) 578, 187-191.

LIU, Y.-J., MU, Y.-J., ZHU, Y.-G., DING, H., ARENS, N.C. (2007): Which ornamental plant species effectively remove benzene from indoor air? Atmospheric Environment 41, 650 654. DOI: http://dx.doi.org/10.1016/j.atmosenv.2006.08.001

MAENE, L., DEBERGH, P. (1985): Liquid medium additions to established tissue cultures to improve elongation and rooting in vivo. Plant Cell Tiss. Org. Cult. 5, 23-33. DOI: http://dx.doi.org/10.1007/BF00033566

MAGYAR-TÁBORI, K., DOBRÁNSZKI, J., JÁMBOR-BENCZÚR, E. (2002): High in vitro shoot proliferation in the apple cultivar Jonagold induced by benzyladenine analogues. Acta Agron. Hung. 50, 191-195. DOI: http://dx.doi.org/10.1556/AAgr.50.2002.2.11 
MALÁ, J., CVRČKOVÁ, H., MÁCHOVÁ, P. (2009): Mikropropagace jeřábu břeku (Sorbus torminalis (L.) Crantz). Výzkumný ústav lesního hospodářství a myslivosti, Strnady.

MALABADI, R.B., MULGUND, G.S., KALLAPPA, N. (2005): Micropropagation of Dendrobium nobile from shoot tip sections. J. Plant Physiol. 162, 473-478. DOI: http://dx.doi.org/10.1016/j.jplph.2004.09.008

MÁNDY, A., KOMISZÁR, L., HONFI, P., TREER, A. (2006): Cserepes levéldísznövények, Budapest: Dísznövény Szövetség és Terméktanács. 112 p.

MANIVANNAN, P., JALEEL, C.A., KISHOREKUMAR, A., SANKAR, B., SOMASUNDARAM, R., PANNEERSELVAM, R. (2008): Protection of Vigna unguiculata (L.) Walp. plants from salt stress by paclobutrazol. Colloids and Surfaces B: Biointerfaces 61, 315-318. DOI: http://dx.doi.org/10.1016/j.colsurfb.2007.09.007

MARTIN, K.P., MADASSERY, J.P. (2006): Rapid in vitro propagation of Dendrobium hybrids through direct shoot formation from foliar explants and protocorm like bodies. Sci. Hort. 108, 95-99. DOI: http://dx.doi.org/10.1016/j.scienta.2005.10.006

MCCONNELL, D.B., CHEN, J., HENNY, R.J., PENNISI, S.V. AND KANE, M.E. (2003): Growth responses of Spathiphyllum cultivars to elevated production temperatures. Acta Hort. (ISHS) 620, 273-279.

MEINERS, J., SCHWAB, M., SZANKOWSKI, I., (2007): Efficient in vitro regeneration systems for Vaccinium species. Plant Cell Tiss. Org. Cult. 89, 169-176. DOI: http://dx.doi.org/10.1007/s11240-007-9230-7

MELIS, A. (1991): Dynamics of photosynthetic membrane composition and function. BBA Bioenergetics 1058, 87-106. DOI: http://dx.doi.org/10.1016/S0005-2728(05)80225-7

MERTENS, M., WERBROUCK, S., SAMYN, G., BOTELHO DOS SANTOS, MOREIRA DA SILVA, H., DEBERGH, P. (1996): In vitro regeneration of evergreen azalea from leaves. Plant Cell Tiss. Org. Cul. 45, 231-236. DOI: http://dx.doi.org/10.1007/BF00043635

MEYER, E.M., TOUCHELL, D.H., RANNEY, T.G. (2009): In Vitro shoot regeneration and polyploid induction from leaves of Hypericum species. HortScience 44, 1957-1961.

MOK, M.C., MOK, D.W.S. (1985): The metabolism of [14C]-TDZ in callus tissues of Phaseolus lunatus. Physiol. Plant. 65, 427-432. DOI: http://dx.doi.org/10.1111/j.13993054.1985.tb08668.x

MOREL, G. (1960): Producing virus-free Cymbidiums. Am. Orchid Soc. Bull. 29, 495-497.

MOREL, G., (1970): Neues auf dem Gebiet der Meristem-Forschung. Die Orchidee 20, 433443.

MURALI, T.P., DUNCAN, E.J. (1995): The effects of in vitro hardening using triazoles on growth and acclimatization of banana. Sci. Hort. 64, 243-251. DOI: http://dx.doi.org/10.1016/0304-4238(95)00848-9

MURASHIGE, T., SKOOG, F. (1962): A revised medium for rapid growth and bio assays with tobacco tissue cultures. Physiol. Plant. 15, 473-497. DOI: http://dx.doi.org/10.1111/j.13993054.1962.tb08052.x 
MURTHY, B.N.S., MURCH, S.J., SAXENA, P.K. (1998): Thidiazuron: A potent regulator of in vitro plant morphogenesis. In Vitro Cell. Dev. Biol. Plant 34, 267-275. DOI: http://dx.doi.org/10.1007/BF02822732

MURTHY, H.N., PYATI, A.N. (2001): Micropropagation of Aerides maculosum Lindl. (Orchidaceae). In Vitro Cell. Dev. Biol. 37, 223-226. DOI: http://dx.doi.org/10.1007/s11627-001-0039-5

NAGY, M., TARI, I., BUBÁN, T. (1991): IAA distribution in the hypocotyls and primary leaves of Phaseolus vulgaris L. treated with paclobutrazol in relation to their rooting capacity. Biochemie und Physiologie der Pflanzen 187, 447-451. DOI: http://dx.doi.org/10.1016/S0015-3796(11)80055-7

NAVARRO, C., TEISSON, C., CÔTE, F., GANRY, J. (1994): Effects of light intensity and $\mathrm{CO}_{2}$ concentration on growth of banana plants (Musa AAA, cultivar "Petite Naine") in vitro and subsequent growth following acclimatization. Sci. Hort. 60, 41-54. DOI: http://dx.doi.org/10.1016/0304-4238(94)90061-2

NORSTOG, K. (1979): Embryo culture as a tool in the study of comparative and developmental morphology. pp. 179-202. In: SHARP, W R; LARSEN, P O; PADDOCK, E F; RAGHAVAN, V: Plant cell and tissue culture - Principles and applications.

OROSZ, J. (2006): A regeneráció egy különleges új útja in vitro a Spathiphyllum floribundum 'Petite' fajta esetén. Diplomamunka, Budapesti Corvinus Egyetem, Kertészettudományi Kar, Budapest.

OYAERT, E., HEEMERS, L., ROELS, S., DEBERGH, P.C. AND VOLCKAERT, E. (2003): Natural flower initiation in Spathiphyllum: influence of day length and light intensity. Acta Hort. (ISHS) 624, 163-169.

PAEK, K.-Y., HAHN, E.-J., SON, S.-H. (2001): Application of bioreactors for large-scale micropropagation systems of plants. In Vitro Cell. Dev. Biol. Plant 37, 149-157. DOI: http://dx.doi.org/10.1007/s11627-001-0027-9

PALEVITZ B.A. (1981): The structure and development of stomatal cells. In: JARVIS P.G., MANSFIELD T.A. (eds.): Stomatal physiology. Cambridge: Cambridge University Press. $230 \mathrm{p}$.

PAMPLIN, E.J., CHAPMAN, J.M. (1975): Sucrose suppression of chlorophyll synthesis in tissue cultures. J. Exp. Bot. 26, 212-220.

PARK, S.Y., MURTHY, H.N., PAEK, K.Y. (2002a): Rapid propagation of Phalaenopsis from floral stalk-derived leaves. In Vitro Cell. Dev. Biol. Plant 38, 168-172. DOI: http://dx.doi.org/10.1079/IVP2001274

PARK, S.Y., MURTHY, H.N., PAEK, K.Y. (2003): Protocorm-like body induction and subsequent plant regeneration from root tip cultures of Doritaenopsis. Plant Sci. 164, 919923. DOI: http://dx.doi.org/10.1016/S0168-9452(03)00019-0

PARK, S.Y., YEUNG, E.C., CHAKRABARTY, D., PAEK, K.Y. (2002b): An efficient direct induction of protocorm-like bodies from leaf subepidermal cells of Doritaenopsis hybrid 
using thin-section culture. Plant Cell Rep. 21, 46-51. DOI: http://dx.doi.org/10.1007/s00299-002-0480-x

PATTANAYAK, G.K., BISWAL, A.K., REDDY, V.S., TRIPATHY, B.C. (2005): Lightdependent regulation of chlorophyll $\mathrm{b}$ biosynthesis in chlorophyllide a oxygenase overexpressing tobacco plants. Biochem. Bioph. Res. Co. 326, 466-471. DOI: http://dx.doi.org/10.1016/j.bbrc.2004.11.049

PELACHO, A.M., MARTÍN-ClOSAS, L., CAMPABADAL, C., TORRES, A., FARRAN, I., MINGO-CASTEL, A.M. (1994): In vitro tuberization of potato: effect of several morphogenic regulators in light and darkness. J. Plant Physiol. 144, 705-709. DOI: http://dx.doi.org/10.1016/S0176-1617(11)80665-6

PEMADASA, M.A. (1982): Differential abaxial and adaxial stomatal responses to indole-3acetic acid in Commelina communis L. New Phytologist 90, 209-219. DOI: http://dx.doi.org/10.1111/j.1469-8137.1982.tb03253.x

PENGWEI, W. (1997): Studies on propagation of Nephrolepis cordifolia in vitro. Journal of Beijing Forestry University 20, 107-109.

POLLOCK, K., BARFIELD, D.G., SHIELDS, R., (1983): The toxicity of antibiotics to plant cell cultures. Plant Cell Rep. 2, 36-39. DOI: http://dx.doi.org/10.1007/BF00269232

RADEMACHER, W. (1991): Biochemical effects of plant growth retardants. pp 169-199. In: GAUSMAN, HW. (ed.) Plant biochemical regulators. New York: Marcel Dekker, New York.

RAMIREZ-MALAGON, R., BORODANENKO, A., BARRERA-GUERRA, J.L., OCHOAALEJO, N. (2001): Shoot number and shoot size as affected by growth regulators in in vitro cultures of Spathiphyllum floribundum L. Sci. Hort. 89, 227-236. DOI: http://dx.doi.org/10.1016/S0304-4238(00)00236-3

RITCHIE, G.A., SHORT, K.C., DAVEY, M.R., (1991): In vitro acclimatization of Chrysanthemum and sugar beet plantlets by treatment with paclobutrazol and exposure to reduced humidity. J. Exp. Bot. 42, 1557-1563. DOI: http://dx.doi.org/10.1093/jxb/42.12.1557

ROELS, S., ESCALONA, M., CEJAS, I., NOCEDA, C., RODRIGUEZ, R., CANAL, M.J., SANDOVAL, J., DEBERGH, P. (2005): Optimization of plantain (Musa AAB) micropropagation by temporary immersion system. Plant Cell Tiss. Org. Cult. 82, 57-66. DOI: http://dx.doi.org/10.1007/s11240-004-6746-y

ROHWER, J.G. (2002): A trópusok növényei. Budapest: Magyar Könyvklub. 288 p.

ROSALES, M.S.D., SOLIS, A.G.A., MENDEZ, N.L.V., BALCH, E.P.M. (2008): Effect of cytokinins on the in vitro propagation of Mexican agaves. Revista Fitotecnia Mexicana 31 (4), 317-322.

RÖBER, R., BÖHMER, B., FEßLER, A. (1994). Topfpflanzenkulturen. Stuttgart: E. Ulmer. $688 \mathrm{p}$.

SÁEZ, P.L., BRAVO, L.A., SÁEZ, K.L., SÁNCHEZ-OLATE, M., LATSAGUE, M.I., RÍOS, D.G. (2012): Photosynthetic and leaf anatomical characteristics of Castanea sativa: a 
comparison between in vitro and nursery plants. Biol. Plant. 56, 15-24. DOI: http://dx.doi.org/10.1007/s10535-012-0010-9

SAHIDIN, N. (2011): Tissue culture of Spathiphyllum wallisii (Peace Lily): Terrarium plant in aquarium. UMTAS 2011, International Annual Symposium, International Conference on Life Science, 750-751.

SAXENA, P.K., MALIK, K.A., GILL, R. (1992): Induction by thidiazuron of somatic embryogenesis in intact seedlings of peanut. Planta 187, 421-424. DOI: http://dx.doi.org/10.1007/BF00195667

SCHMIDT, G. (2002): Növényházi dísznövények termesztése. Budapest: Mezőgazda Kiadó. 672 p.

SHARMA, A., TANDON, P. (1992): In vitro culture of D. wardianum Warner: morphogenetic effects of some heterogenous adjuvants. Indian J. Plant Physiol. 35, 80-85.

SHARMA, V., VIJ, S.P. (1997): Effect of $\mathrm{CuSO}_{4} .5 \mathrm{H}_{2} \mathrm{O}$ on in vitro regenerative capacity of foliar explants excised from mature Vanda cristata Lindl. plants. Phytomorphology 47, 203-208.

SHEELA, V.L., RAJMOHAN, K., ANITA, S., SARADA, S. (2004): Effect of growth regulators on development and multiplication of protocorm like bodies in Dendrobium cv Sonia. $J$. Orchid Soc. India 18, 21-23.

SHIELDS, R., ROBINSON, S.J., ANSLOW, P.A. (1984): Use of fungicides in plant tissue culture. Plant Cell Rep. 3, 33-36. DOI: http://dx.doi.org/10.1007/BF00270226

SHINSHI, H., NOGUCHI, M. (1975): Relationships between peroxidase, IAA oxidase and polyphenol oxidase. Phytochemistry 14, 1255-1258. DOI: http://dx.doi.org/10.1016/S00319422(00)98604-7

SINHA, P., HAKIM, M.K., ALAM, M.F. (2007): Efficient micropropagation of Phalaenopsis amabilis (L) BL. cv. 'Cool Breeze' using inflorescence axis thin sections as explants. Prop. Ornam. Plants 7, 9-15.

SOREANU, G., DIXON, M., DARLINGTON, A. (2013): Botanical biofiltration of indoor gaseous pollutants - A mini-review. Chem. Eng. J. 229, 585-594. DOI: http://dx.doi.org/10.1016/j.cej.2013.06.074

STEBBINS, G.L. (1971): Chromosomal evolution in higher plants. London: Edward Arnold. $216 \mathrm{p}$.

STEINITZ, B., LILIEN-KIPNIS, H. (1989): Control of precocious Gladiolus corm and cormel formation in tissue culture. J. Plant Physiol. 135, 495-500. DOI: http://dx.doi.org/10.1016/S0176-1617(89)80110-5

STRNAD, M. (1997): The aromatic cytokinins. Physiol. Plant. 101, 674-688. DOI: http://dx.doi.org/10.1111/j.1399-3054.1997.tb01052.x

SUBBARAJ, A.K. (2011): Topolins: current research status and applications. Int. J. of BioResource \& Stress Management 2, 10-25.

SUBRAMANIUM, G., TAHA, R.M. (2003): Morphogenesis of Cymbidium atropurpureum in vitro. Malays. J. Sci. 22, 1-5. 
SUTTER, E., LANGHANS, R.W. (1982): Formation of epicuticular wax and its effect on water loss in cabbage plants regenerated from shoot tip culture. Can. J. Bot., 60:2896-2902.

SZALVA, L. (2003): Spathiphyllum fajták in vitro (steril) mikroszaporítása, az indítási, a felszaporítási és az elongációs szakaszok vizsgálatával. Diplomamunka, Szent István Egyetem (jelenleg BCE), Kertészettudományi Kar, Budapest.

TAKAYAMA, S., MISAWA, M. (1981): Mass propagation of Begonia $\times$ hiemalis plantlets by shake culture. Plant Cell Physiol. 22, 461-467.

TAN NHUT, D., TAKAMURA, T., WATANABE, H. AND TANAKA, M. (2005): Artificial light source using light-emitting diodes (leds) in the efficient micropropagation of Spathiphyllum plantlets . Acta Hort. (ISHS) 692, 137-142

TANAKA, M., NAGAE, S., FUKAI, S., GOI, M. (1992): Growth of tissue cultured Spathiphyllum on rock-wool in a novel film culture vessel under high $\mathrm{CO}_{2}$. Acta Hort. (ISHS) 314, 139-146.

TANAKA, M., NAGAE, S., TAKAMURA, T., KUSANAGI, N., UJIKE, M., GOI, M. (1996): Efficiency and application of film culture system in the in vitro production of plantlets in some horticultural crops. Shokubutsu Kojo Gakkaishi 8, 280-285.

TANAKA, R., IKEDA, H. (1983): Perennial maintenance of annual Haplopapus gracilis ( $2 \mathrm{n}=$ 4) by shoot tip cloning. Jpn. J. Genet. 58, 65-70. DOI: http://dx.doi.org/

TARI, I. (2003): Abaxial and adaxial stomatal density, stomatal conductances and water status of bean primary leaves as affected by paclobutrazol. Biol. Plant. 47, 215-220. DOI: http://dx.doi.org/10.1023/B:BIOP.0000022254.63487.16

TEISSON, C., Alvard, D., BERThOUlY, B., CÔTE, F., ESCALANT, J.V., ETIENNE, H., LARTAUD, M. (1996): Simple apparatus to perform plant tissue culture by temporary immersion. Acta Hort. (ISHS) 440, 521-526.

TEIXEIRA DA SILVA, J.A., GIANG, D.D.T., TANAKA, M. (2006): Photoautotrophic micropropagation of Spathiphyllum. Photosynthetica 44, 53-61. DOI: http://dx.doi.org/10.1007/s11099-005-0158-z

TEKALIGN, T., HAMMES, P.S. (2004): Response of potato grown under non-inductive condition paclobutrazol: shoot growth, chlorophyll content, net photosynthesis, assimilate partitioning, tuber yield, quality, and dormancy. Plant Growth Regul. 43, 227-236. DOI: http://dx.doi.org/10.1023/B:GROW.0000045992.98746.8d

TENG, W.L., NICHOLSON, L., TENG, M.C. (1997): Micropropagation of Spathoglottis plicata. Plant Cell Rep. 16, 831-835. DOI: http://dx.doi.org/10.1007/s002990050329

THEODORIDIS, G. (2006): Fluorine-containing agrochemicals: an overview of recent developments. pp. 121-175. In: ALAIN TRESSAUD (szerk.), Advances in fluorine science, fluorine and the environment agrochemicals, archaeology, green chemistry \& water. Elsevier.

TIAN, C., CHEN, Y., ZHAO, X., ZHAO, L. (2008): Plant regeneration through protocorm-like bodies induced from rhizoids using leaf explants of Rosa spp. Plant Cell Rep. 27, 823-831. DOI: http://dx.doi.org/10.1007/s00299-007-0504-7 
TÓTH, E. (2005): A mikroszaporítás gazdaságossági vonatkozásai. In: Jámborné Benczúr, E. (szerk.), Dobránszki, J (szerk.), 2005. Kertészeti növények mikroszaporítása: in vitro növényklónozás. Mezogazda, Budapest. pp. 307-308.

UDVARDY, L. (2008): A kertészeti növénytan növényismereti kompendiuma, 3. ed. Budapest: Budapesti Corvinus Egyetem Kertészettudományi Kara és Mezőgazda Kiadó. 124 p.

UPRETI, K.K., REDDY, Y.T.N., PRASAD, S.R.S., BINDU, G.V., JAYARAM, H.L., RAJAN, S. (2013): Hormonal changes in response to paclobutrazol induced early flowering in mango cv. Totapuri. Sci. Hort. 150, 414-418. DOI: http://dx.doi.org/10.1016/j.scienta.2012.11.030

VAN DEN BERG, ELBERT (ed.) (2002): Spathiphyllum. Vakblad voor de Bloemisterij 23a(57), 93.

VAN DEN BERG, ELBERT (ed.) (2003): Spathiphyllum. Vakblad voor de Bloemisterij 21a(58), 115-116.

VAN DEN BERG, ELBERT (ed.) (2004): Spathiphyllum. Vakblad voor de Bloemisterij 21a(59), 117.

VAN DEN BERG, ELBERT (ed.) (2007): Spathiphyllum. Vakblad voor de Bloemisterij 21a(62), 105.

VAN DEN BERG, ELBERT (ed.) (2008): Spathiphyllum. Vakblad voor de Bloemisterij 21a(63), 109.

VAN DEN BERG, ELBERT (ed.) (2009): Spathiphyllum. Vakblad voor de Bloemisterij 21a(64), 130.

VAN DEN BERG, ELBERT (ed.) (2010): Spathiphyllum. Vakblad voor de Bloemisterij 23a(65), 108.

VAN HUYLENBROECK, J., DEBERGH, P. (1996): Impact of sugar concentration in vitro on photosynthesis and carbon metabolism during ex vitro acclimatization of Spathiphyllum plantlets. Physiol. Plant. 96, 298-304.

VAN HUYLENBROECK, J., DEBERGH, P.C. (2000): Monitoring quality of micropropagated plants during acclimatization. Acta Hort. (ISHS) 517, 65-72.

VAN HUYLENBROECK, J., PIQUERAS, A., DEBERGH, P. (1998): Photosynthesis and carbon metabolism in leaves formed prior and during ex vitro acclimatization of micropropagated plants. Plant Sci. 134, 21-30. DOI: http://dx.doi.org/10.1016/S01689452(98)00043-0

VAN HUYLENBROECK, J.M., DE RIEK, J. (1995): Sugar and starch metabolism during ex vitro rooting and acclimatization of micropropagated Spathiphyllum "Petite" plantlets. Plant Sci. 111, 19-25. DOI: http://dx.doi.org/10.1016/0168-9452(95)04223-H

VAN HUYLENBROECK, J.M., HUYGENS, H., DEBERGH, P.C. (1995): Photoinhibition during acclimatization of micropropagated Spathiphyllum "Petite" plantlets. In Vitro Cell. Dev. Biol. Plant 31, 160-164. DOI: http://dx.doi.org/10.1007/BF02632013

VAN HUYSTEE, R.B. (1977): Porphyrin metabolism in peanut cells cultured in sucrose containing medium. Acta Hort. (ISHS) 78, 83-87. 
VANSTECHELMAN, I., VANSTEENKISTE, H., VAN HUYLENBROECK, J., VAN LABEKE, M. C. (2009): Morphological and anatomical characterisation of chemically induced polyploids in Spathiphyllum wallisii. Acta Hort. (ISHS) 836, 79-84.

VARDJA, R., VARDJA, T. (2001): The effect of cytokinin type and concentration and the number of subcultures on the multiplication rate of some decorative plants. Proc. Eston. Acad. Sci. 50(1), 22-32.

VARGAS, T.E., GARCIA, E. DE (1997): Propagacion in vitro de Cala blanca Spathiphyllum sp. Agron. Tropic. 47(2),171-183.

VIJ, S.P. (1993): Regeneration response of orchid roots: A study in vitro. J. Orchid Soc. India 7, 61-72.

VIJ, S.P., KAUR, P. (1999): Rapid clonal multiplication of Ascocenda 50th State Beauty through in vitro culture of leaf explants. Proc. Natl. Acad. Sci. India 69, 317-321.

VISSER, C., QURESHI, J.A., GILL, R., SAXENA, P.K. (1992): Morphoregulatory role of thidiazuron substitution of auxin and cytokinin requirement for the induction of somatic embryogenesis in Geranium hypocotyl cultures. Plant Physiol. 99, 1704-1707. DOI: http://dx.doi.org/10.1104/pp.99.4.1704

VISSERS, M., HALEYDT, B. (1994): Gibberelline toepassingen bij Spathiphyllum. Verbondsnieuws 38:18-19.

WANG, S.Y., STEFFENS, G.L., FAUST, M. (1986): Effect of paclobutrazol on cell wall polysaccharide composition of the apple tree. Phytochemistry 25, 2493-2496. DOI: http://dx.doi.org/10.1016/S0031-9422(00)84494-5

WANG, S.Y., SUN, T., JI, Z.L., FAUST, M. (1987): Effect of paclobutrazol on water stressinduced abscisic acid in apple seedling leaves. Plant Physiol. 84, 1051-1054. DOI: http://dx.doi.org/10.1104/pp.84.4.1051

WANG, Y.Y., ZHOU, R., ZHOU, X. (1994): Endogenous levels of ABA and cytokinins and their relation to stomatal behavior in dayflower (Commelina communis L.). J. Plant Physiol. 144, 45-48. DOI: http://dx.doi.org/10.1016/S0176-1617(11)80990-9

WARDLE, K., C. SHORT, K. (1983): Stomatal response of in vitro cultured plantlets. I. Responses in epidermal strips of chrysanthemum to environmental factors and growth regulators. Biochemie und Physiologie der Pflanzen 178, 619-624. DOI: http://dx.doi.org/10.1016/S0015-3796(83)80076-6

WARDLE, K., DOBBS, E.B., SHORT, K.C. (1983): In vitro acclimatization of aseptically cultured plantlets to humidity. J. Am. Soc. Hortic. Sci. 108, 386-38.

WATAD, A.A., RAGHOTHAMA, K.G., KOCHBA, M., NISSIM, A., GABA, V. (1997): Micropropagation of Spathiphyllum and Syngonium is facilitated by use of interfacial membrane rafts. HortScience 32, 307-308.

WEN, Z.Z., LIN, Y., LIU, Y.Q., WANG, M., WANG, Y.Q., LIU, W. (2013): Effects of paclobutrazol in vitro on transplanting efficiency and root tip development of Dendrobium nobile. Biol. Plant. 57, 576-580. DOI: http://dx.doi.org/10.1007/s10535-013-0319-z 
WERBROUCK, S.P.O., DEBERGH, P.C. (1995):. Imazalil enhances the shoot-inducing effect of benzyladenine in Spathiphyllum floribundum Schott. J. Plant Growth Regul. 14, 105-107. DOI: http://dx.doi.org/10.1007/BF00203121

WERBROUCK, S.P.O., DEBERGH, P.C. (1996): Imidazole fungicides and paclobutrazol enhance cytokinin-induced adventitious shoot proliferation in Araceae. J. Plant Growth Regul.15, 81-85. DOI: http://dx.doi.org/10.1007/BF00192936

WERBROUCK, S.P.O., EECKHAUT, T.G.R., DEBERGH, P.C. (2000): Induction and conversion of somatic embryogenesis on the anther filament of Spathiphyllum Schott. Acta Hort. (ISHS) 520, 263-270.

WERBROUCK, S.P.O., JEUGT, B. VAN DER, DEWITTE, W., PRINSEN, E., ONCKELEN, H.A.V., DEBERGH, P.C. (1995): The metabolism of benzyladenine in Spathiphyllum floribundum "Schott Petite" in relation to acclimatisation problems. Plant Cell Rep. 14, 662665. DOI: http://dx.doi.org/10.1007/BF00232734

WERBROUCK, S.P.O., REDIG, P., ONCKELEN, H.A.V., DEBERGH, P.C. (1996): Gibberellins play a role in the interaction between imidazole fungicides and cytokinins in Araceae. J. Plant Growth Regul. 15, 87-93. DOI: http://dx.doi.org/10.1007/BF00192937

WETZSTEIN, H.Y., SOMMER, H.E. (1982):. Leaf anatomy of tissue-cultured Liquidambar styraciflua (Hamamelidaceae) during acclimatization. Am. J. Bot. 69, 1579. DOI: http://dx.doi.org/10.2307/2442913

WOJTANIA, A., GABRYSZEWSKA, E. (2001): Effect of cytokinins and amino acids on multiplication of Pelargonium cultivars. Acta Soc. Bot. Pol. 70, 203-207. http://dx.doi.org/10.5586/asbp.2001.026

WU, L.-J. (2001): A study on the tissue culture Spathiphyllum floribundum. Journal of Fujian College of Forestry 21(2), 169-172.

XIAO, Y., NIU, G., KOZAI, T. (2011): Development and application of photoautotrophic micropropagation plant system. Plant Cell Tiss. Org. Cult. 105, 149-158. DOI: http://dx.doi.org/10.1007/s11240-010-9863-9

YANG, J.F., PIAO, X.C., SUN, D., LIAN, M.L. (2010): Production of protocorm-like bodies with bioreactor and regeneration in vitro of Oncidium "Sugar Sweet". Sci. Hort. 125, 712 717. DOI: http://dx.doi.org/10.1016/j.scienta.2010.05.003

YASUGI, S., SAKAMOTO, K., ONODERA, K., TAMASHIRO, M. (1994): Plantlet regeneration in root segment culture of Cymbidium Kenny 'Wine Color'. Plant Tiss. Cult. Lett. 11, 150-152.

YOUNG, P.S., MURTHY, H.N., YOEUP, P.K. (2000): Mass multiplication of protocorm-like bodies using bioreactor system and subsequent plant regeneration in Phalaenopsis. Plant Cell Tiss. Org. Cult. 63, 67-72. DOI: http://dx.doi.org/10.1023/A:1006420116883

YU, Y., LIU, L., LIU, J., WANG, J., 2009. Plant Regeneration by Callus-Mediated ProtocormLike Body Induction of Anthurium andraeanum Hort. Agricultural Sciences in China 8, 572-577. DOI: http://dx.doi.org/10.1016/S1671-2927(08)60248-5 
ZEIGER, E. (1983): The Biology of Stomatal Guard Cells. Annu. Rev. Plant Physiol. 34, 441474. DOI: http://dx.doi.org/10.1146/annurev.pp.34.060183.002301

ZHAO, J., CUI, J., LIU, J., LIAO, F., HENNY, R.J., CHEN, J. (2012): Direct somatic embryogenesis from leaf and petiole explants of Spathiphyllum "Supreme" and analysis of regenerants using flow cytometry. Plant Cell Tiss. Org. Cult. 110, 239-249. DOI: http://dx.doi.org/10.1007/s11240-012-0146-5

ZHENG, R., WU, Y., XIA, Y. (2012): Chlorocholine chloride and paclobutrazol treatments promote carbohydrate accumulation in bulbs of Lilium Oriental hybrids "Sorbonne". J. Zhejiang Univ. Sci. B 13, 136-144. DOI: http://dx.doi.org/10.1631/jzus.B1000425

ZHU, L.-H., VAN DE PEPPEL, A., LI, X.-Y., WELANDER, M. (2004): Changes of leaf water potential and endogenous cytokinins in young apple trees treated with or without paclobutrazol under drought conditions. Sci. Hort. 99, 133-141. DOI: http://dx.doi.org/10.1016/S0304-4238(03)00089-X

ZIV, M. (2005): Simple bioreactors for mass propagation of plants. Plant Cell Tiss. Org. Cult. 81, 277-285. DOI: http://dx.doi.org/10.1007/s11240-004-6649-y

ZIV, M. (2010): Bioreactor technology for plant micropropagation. pp. 1-30. In: JANICK, J. (szerk.), Horticultural Reviews. John Wiley \& Sons, Inc.

ZIV, M., RONEN, G., RAVIV, M. (1998): Proliferation of meristematic clusters in disposable presterilized plastic bioreactors for the large-scale micropropagation of plants. In Vitro Cell. Dev. Biol. Plant 34, 152-158. DOI: http://dx.doi.org/10.1007/BF02822781 


\section{Melléklet}

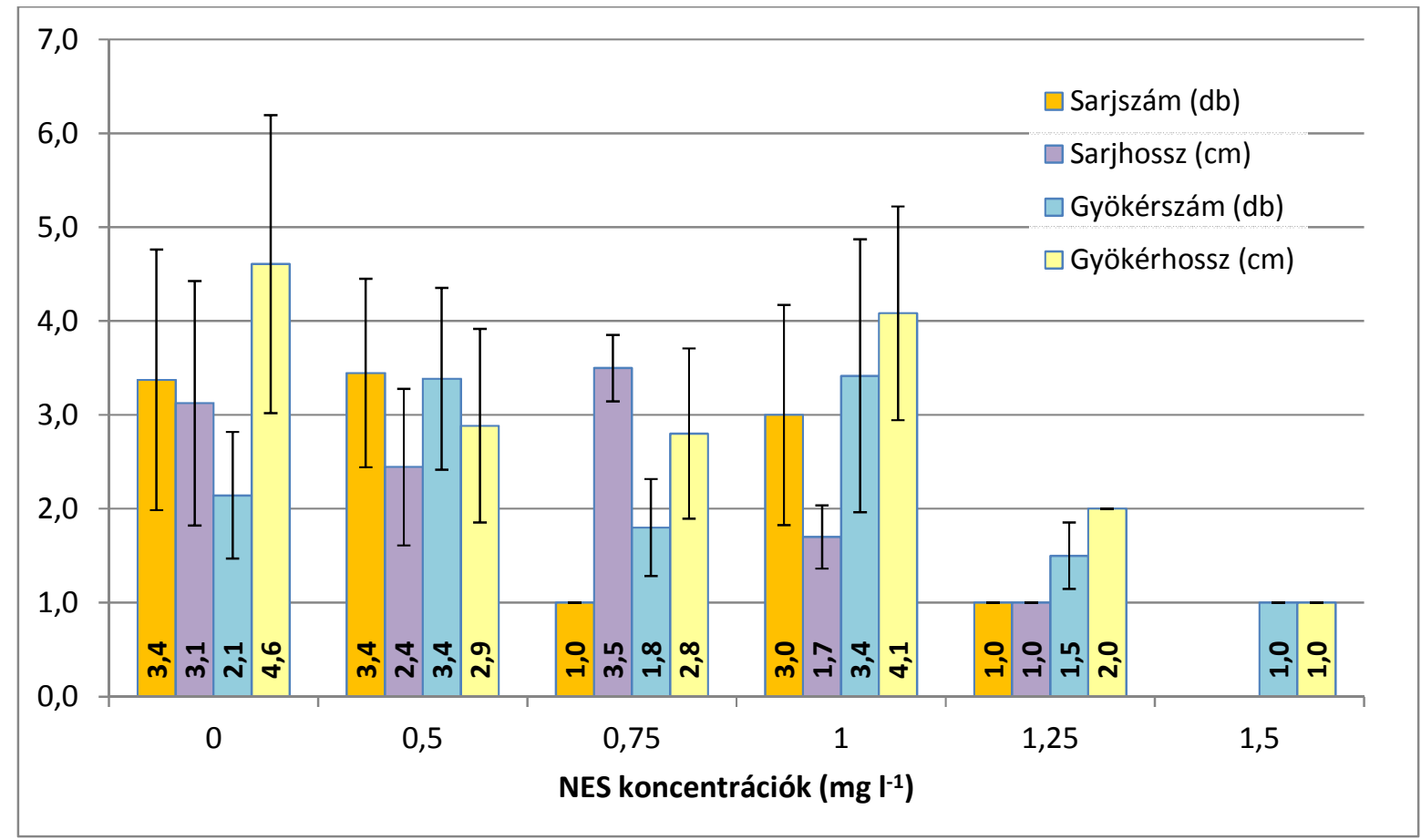

76. ábra. Spathiphyllum floribundum 'Petite' in vitro GGb tenyészeteinél a hajtássá regenerálódott GGb telepekben a sarjak, gyökerek telepenkénti átlagos száma és hossza az eltérö kezeléseknél.

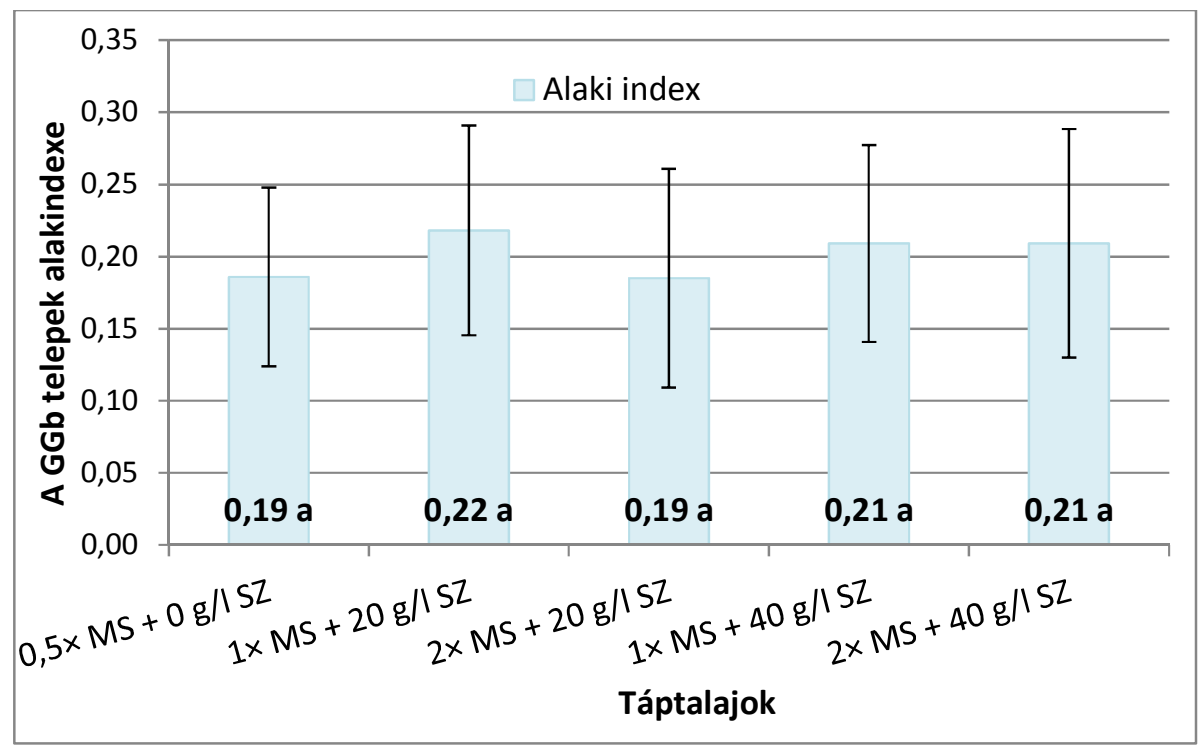

77. ábra. Az emelt makroelem- és szacharózkoncentráció hatása a GGb-telepek alakindexére Spathiphyllum floribundum 'Petite' in vitro tenyészetében. Az eltérö betük szignifikáns különbséget jelölnek, Games-Howell teszt, p<0,05. 


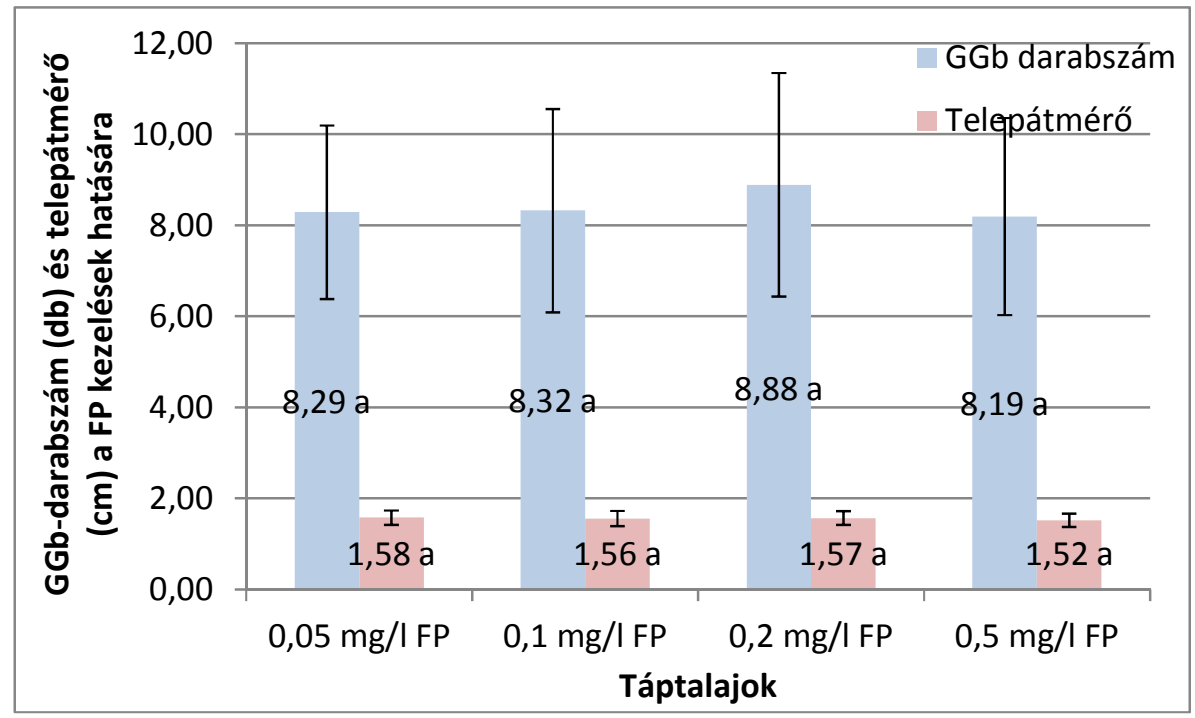

78. ábra. A FP-kezelések hatása a GGb-telepátmérö és a telepen belül GGb-szám alakulására Spathiphyllum floribundum 'Petite' in vitro tenyészetében. Az eltérő betük szignifikáns különbséget jelölnek, Games-Howell teszt, p<0,05.

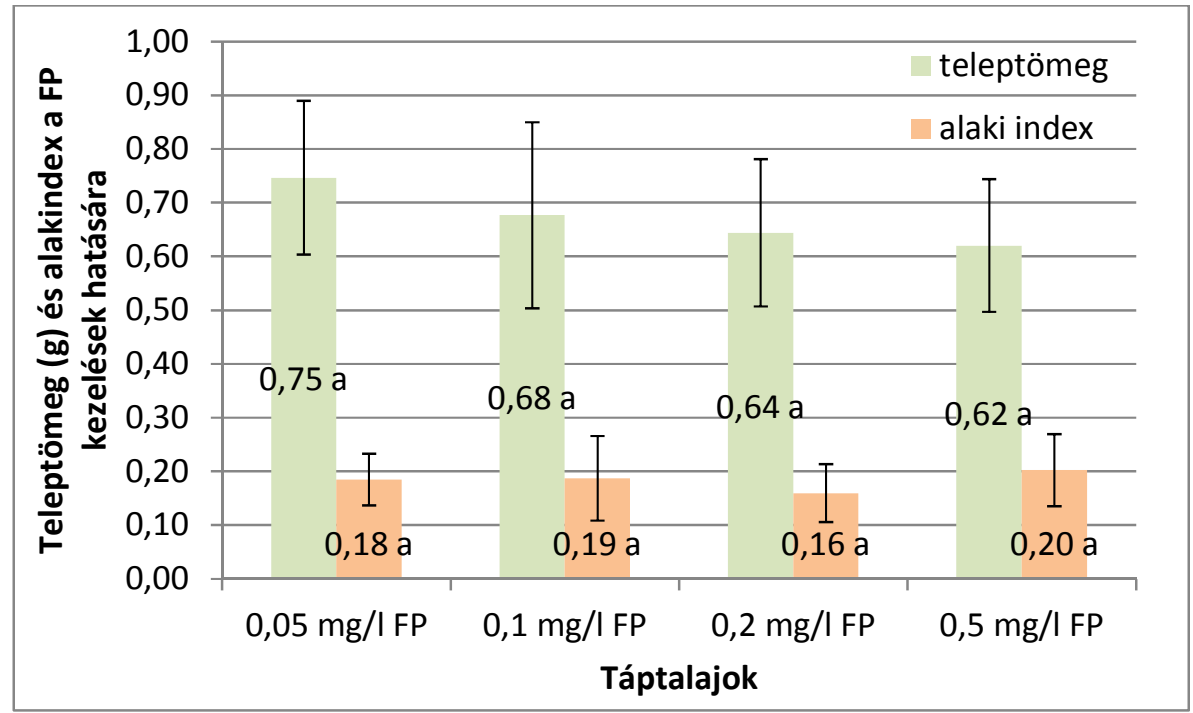

79. ábra. A FP-kezelések hatása a GGb-telepek tömegére és alakindexének alakulására Spathiphyllum floribundum 'Petite' in vitro tenyészetében. Az eltérő betűk szignifikáns különbséget jelölnek, Games-Howell teszt, p<0,05. 


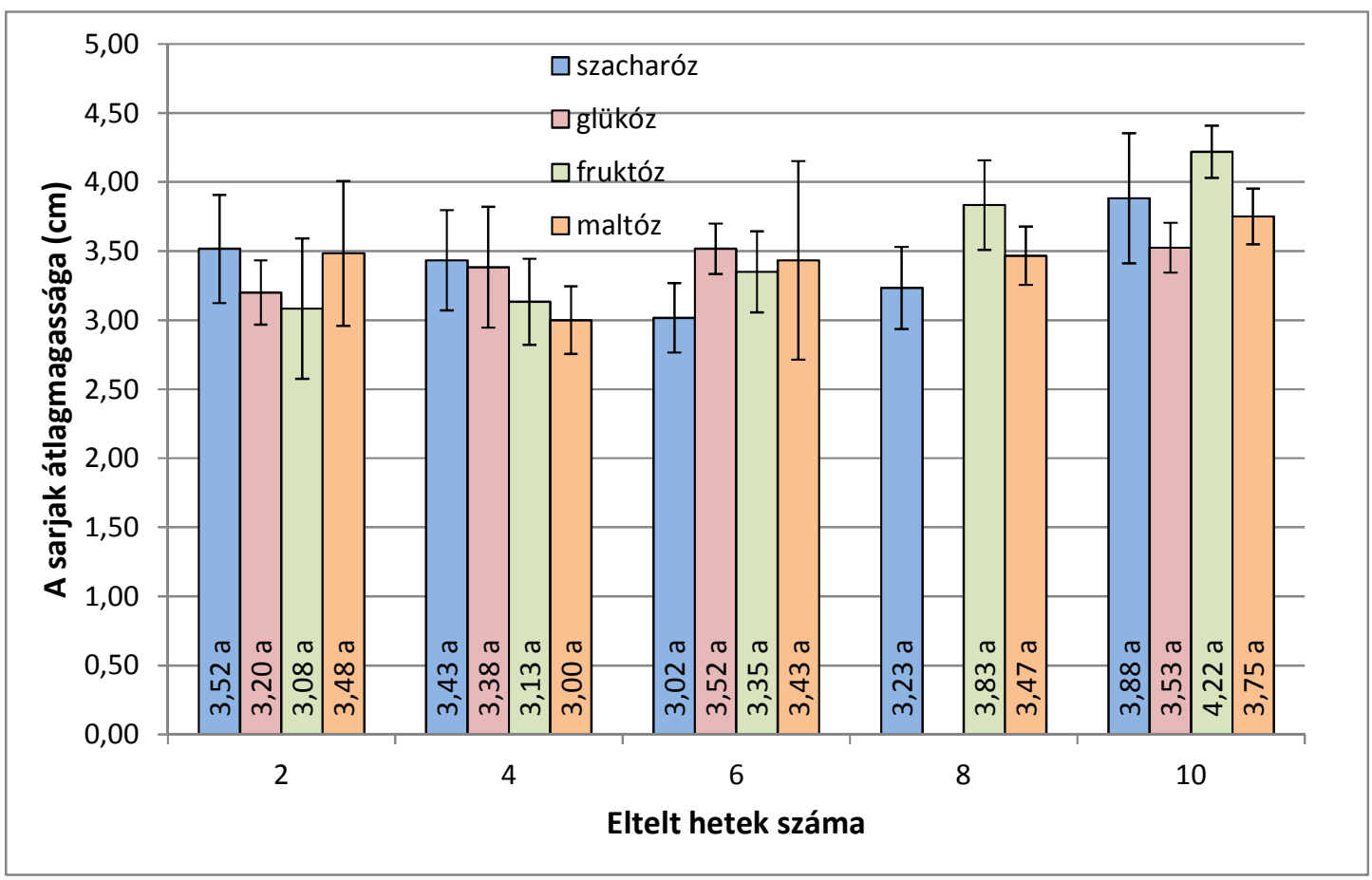

80. ábra. A különböző szénhidráttípusok hatása a sarjak átlagmagasságának alakulására kéthetes időközönként Spathiphyllum floribundum 'Petite' in vitro tenyészetében. A szignifikáns eltérések jelölése mérési pontokon belül a kezelések között értendő, Games-Howell teszt, p<0,05.

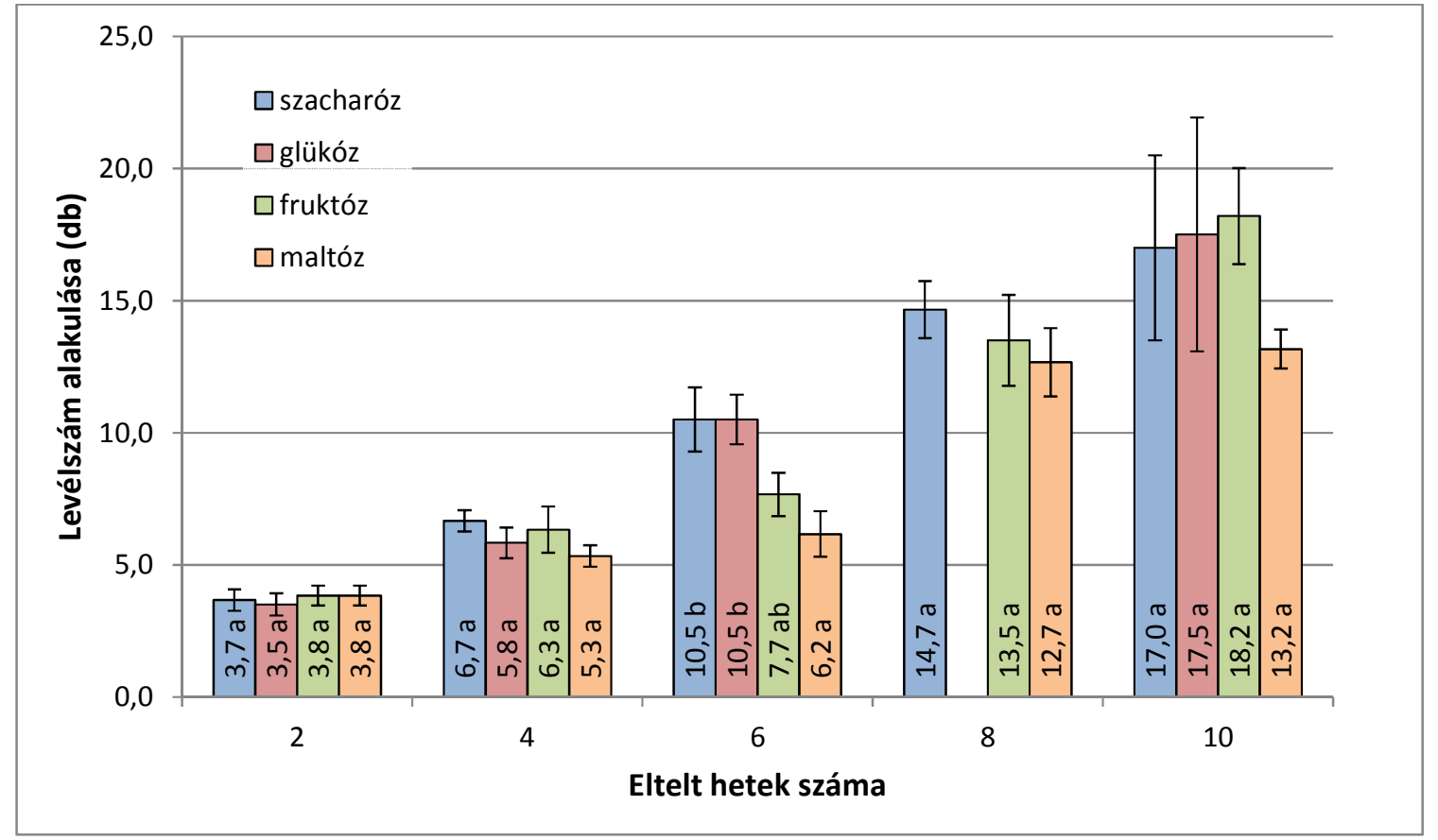

81. ábra. A különböző szénhidráttípusok hatása a sarjtelepek levélszámának alakulására kéthetes időközönként Spathiphyllum floribundum 'Petite' in vitro tenyészetében. A szignifikáns eltérések jelölése mérési pontokon belül a kezelések között értendő, Games-Howell teszt, p<0,05. 


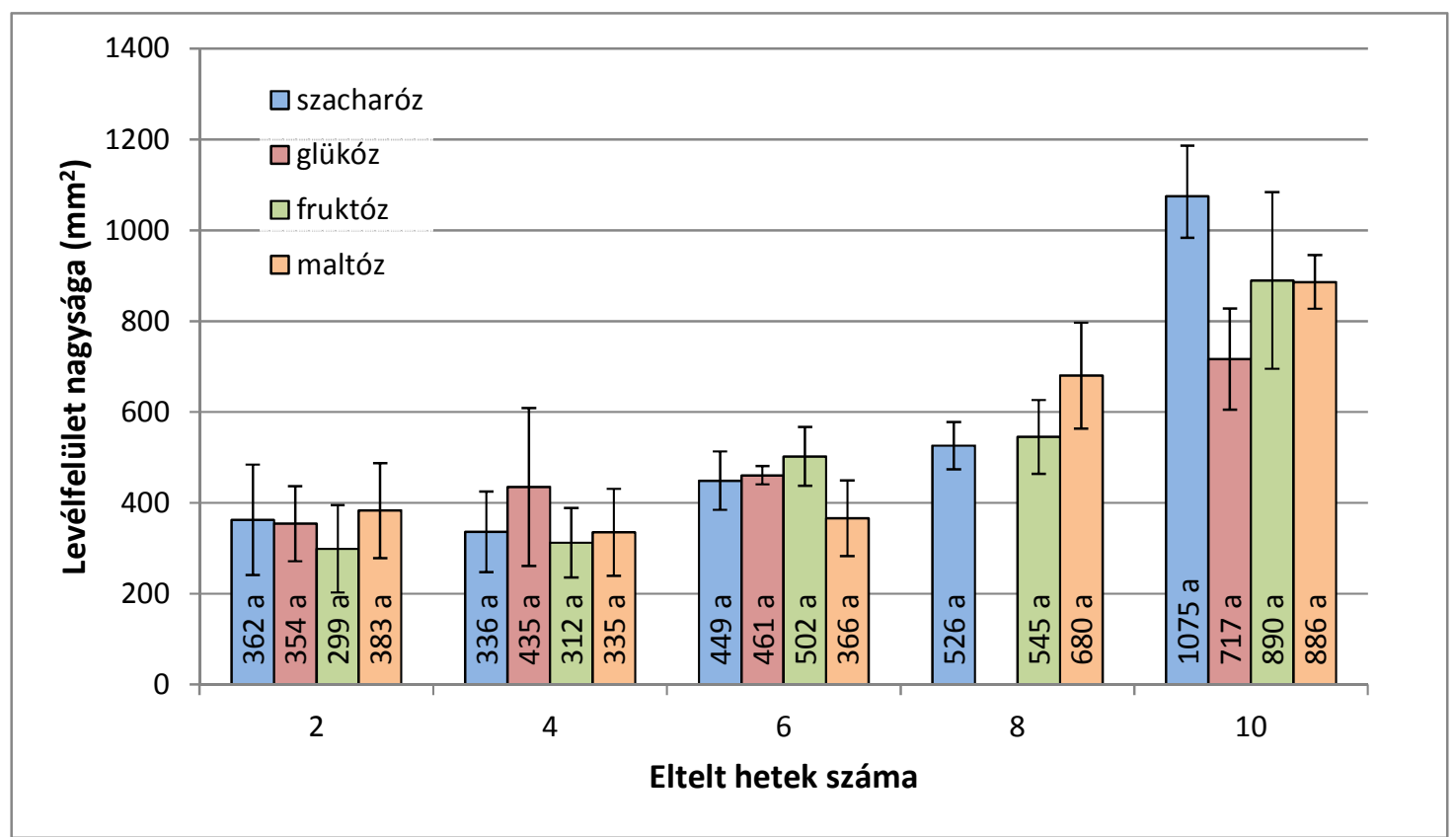

82. ábra A különböző szénhidráttípusok hatása a levélfelület-növekedésre kéthetes időközönként Spathiphyllum floribundum 'Petite' in vitro tenyészetében. A szignifikáns eltérések jelölése mérési pontokon belül a kezelések között értendő, Games-Howell teszt, p<0,05.

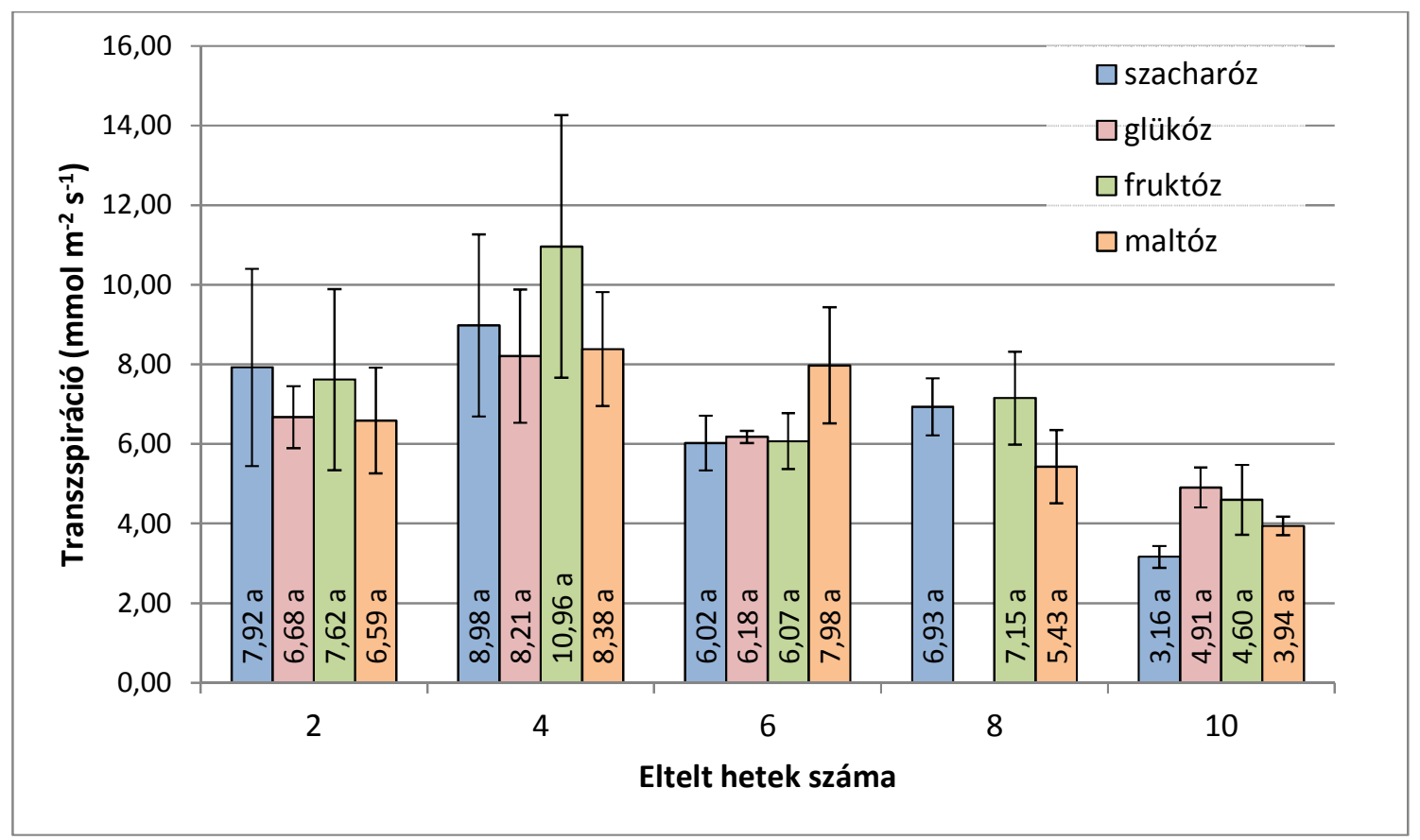

83. ábra. A különböző szénhidráttípusok hatása a transzspirációra Spathiphyllum floribundum 'Petite' sarjtenyészeténél kéthetes időközönként vizsgálva (mérési pontonként eltérő növényeken, $n=6$ ). A szignifikáns eltérések jelölése mérési pontokon belïl a kezelések között értendő, Games-Howell teszt, p<0,05. 


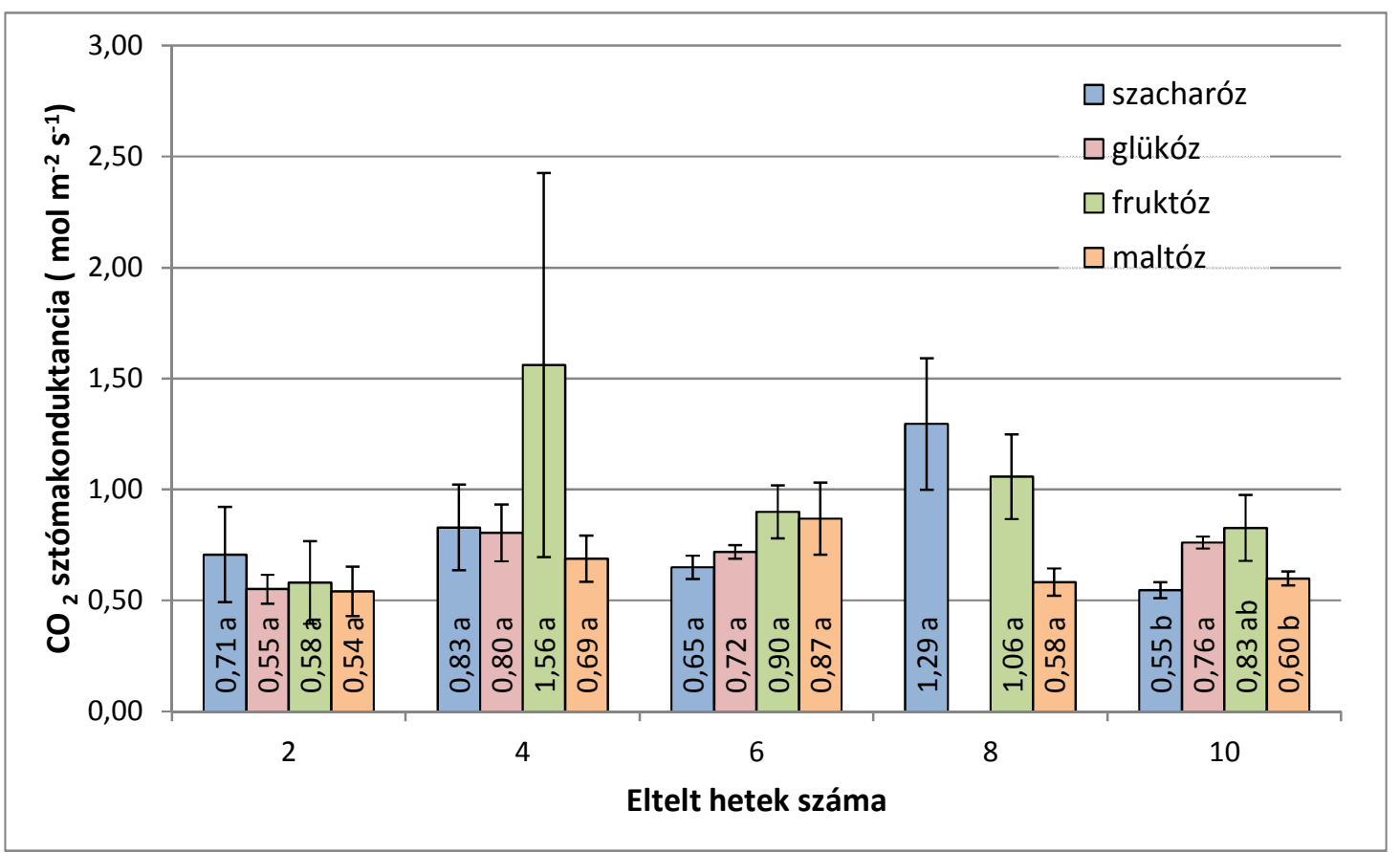

84. ábra. A különböző szénhidráttípusok hatása a $\mathrm{CO}_{2}$ sztómakonduktanciára Spathiphyllum floribundum 'Petite' sarjtenyészeténél kéthetes időközönként vizsgálva (mérési pontonként eltérő növényeken, $n=6$ ). A szignifikáns eltérések jelölése mérési pontokon belül a kezelések között értendő, Games-Howell teszt, p<0,05.

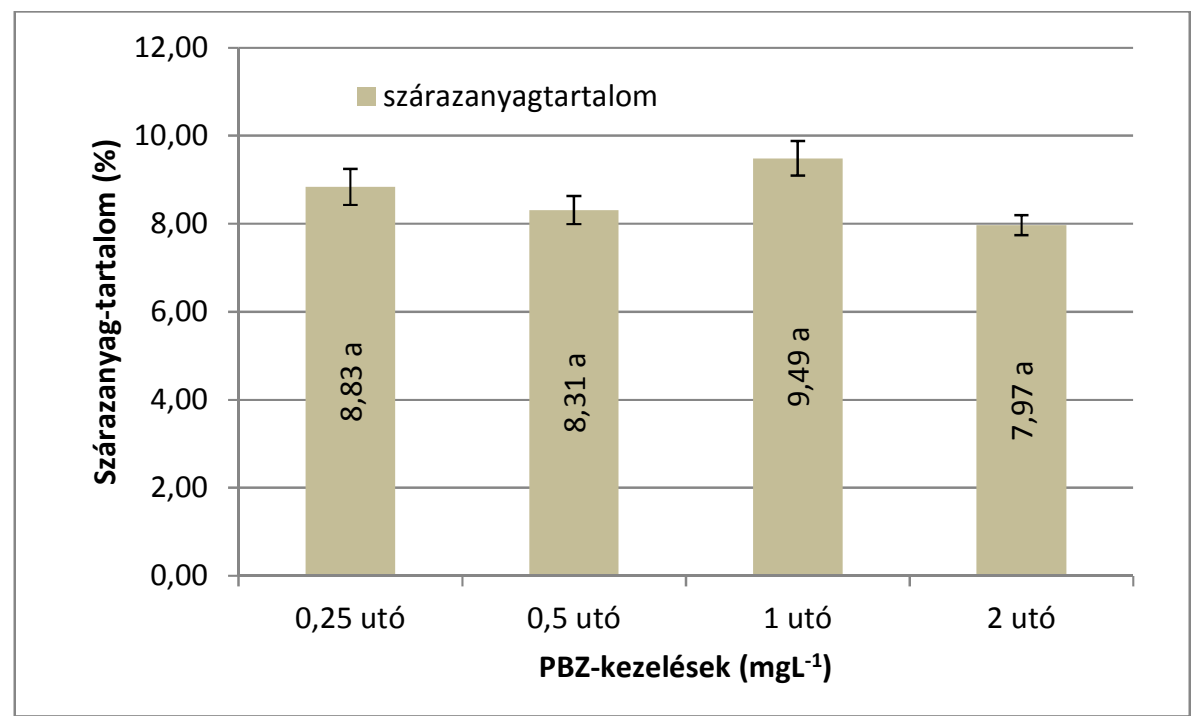

85. ábra A PBZ-kezelés utóhatásának vizsgálata Spathiphyllum floribundum 'Petite' sarjtenyészeténél a szárazanyagtartalom alakulására (az eltérő betük szignifikáns különbséget jelölnek, Games-Howell teszt, p<0,05) 


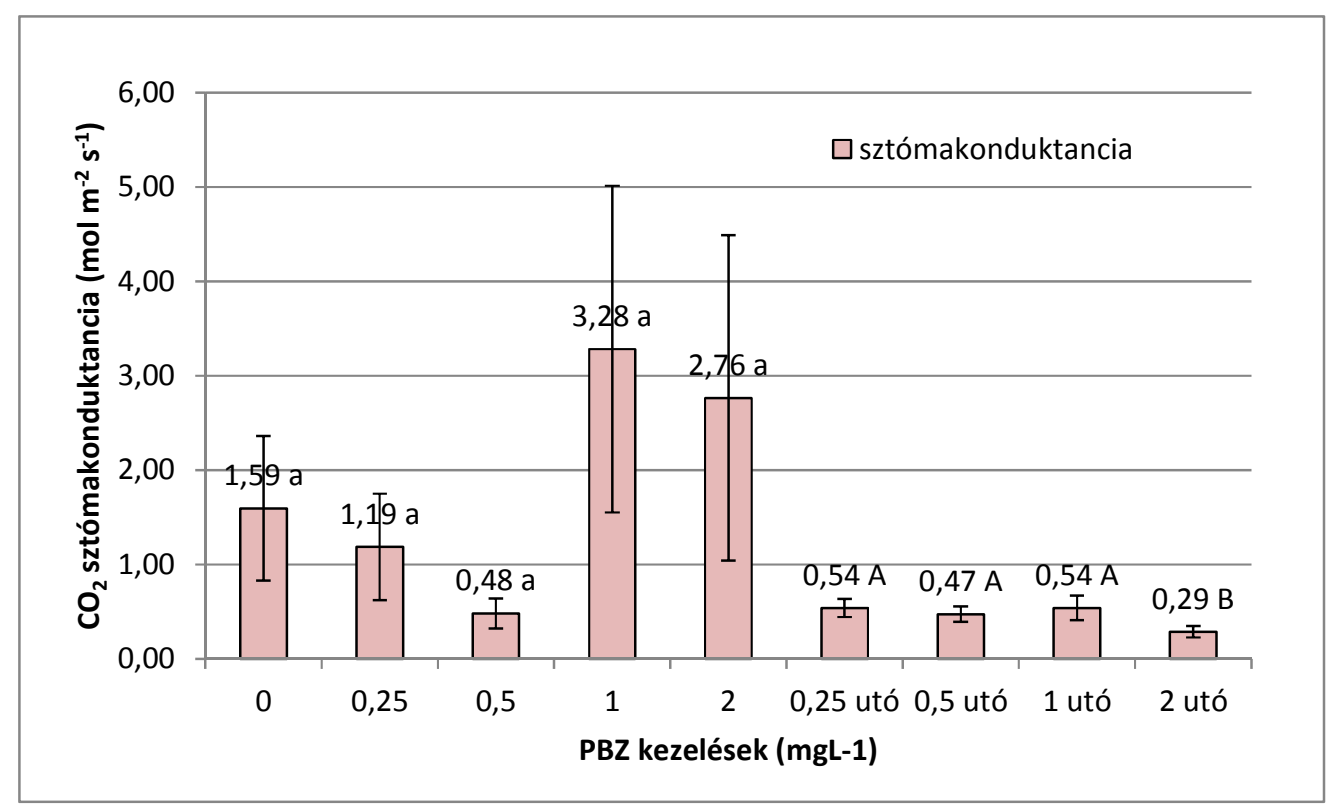

86. ábra A PBZ-kezelések hatásának vizsgálata Spathiphyllum floribundum 'Petite' sarjtenyészeténél a $\mathrm{CO}_{2}$ sztómakonduktancia alakulására (az eltérő betük szignifikáns különbséget jelölnek, külön értendő a kezelésnél és utóhatásvizsgálatnál Games-Howell teszt, p<0,05) 


\section{Köszönetnyilvánítás}

Köszönöm az alábbi személyeknek a munkám során nyújtott segítségüket:

- Tillyné dr. Mándy Andrea konzulensemnek az útmutatást

- Stefanovitsné dr. Bányai Évának az enzimológiai vizsgálati módszerekkel történő megismertetést és konzultációk sorát

- dr. Erős-Honti Zsoltnak a szövettani vizsgálatokban nyújtott segítségét

- dr. Honfi Péternek a dolgozat írása során adott javaslatait

- Jámborné dr. Benczúr Erzsébetnek a téma előzményeinek feltárását és a kutatás folytatásához az anyagok rendelkezésre bocsátását

- dr. Hrotkó Károly tanszékvezető úrnak, hogy lehetővé tette a kutatás lebonyolítását a Dísznövénytermesztési és Dendrológiai Tanszéken

- Berhidi Mártonnak (zer0), Barabás Péternek (z0d) és Tóth Krisztiánnak a munkát gyorsító informatikai megoldásokért és tanácsokért

- és nem utolsósorban családomnak, akik mellettem álltak a munka során. 